
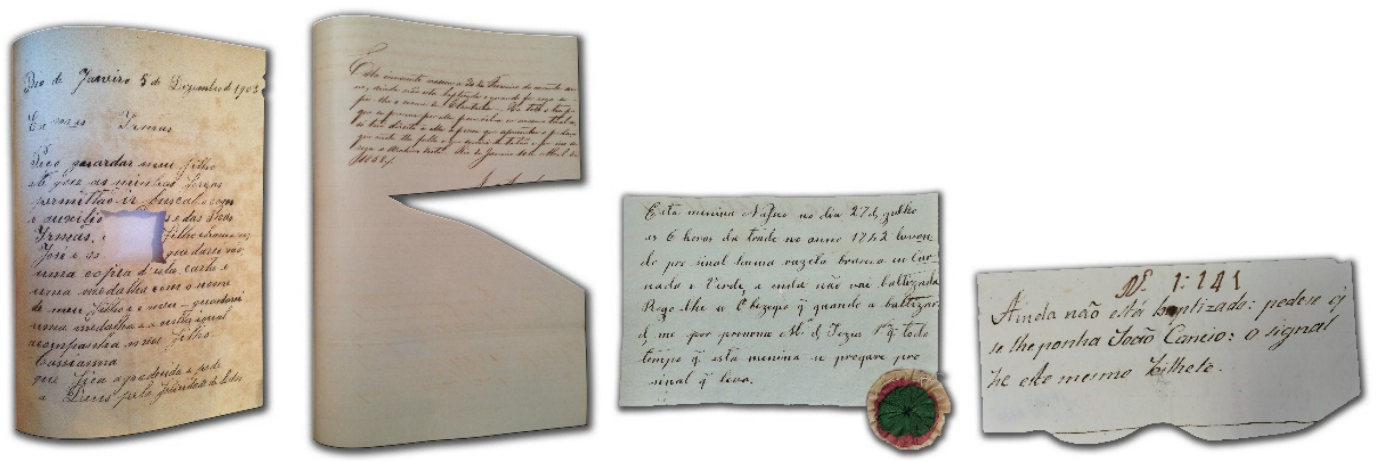

\title{
O sinal é este mesmo bilhete: uma tipologia documental para os escritos da roda dos expostos
}

Tese apresentada ao Programa de Pós-Graduação em Filologia e Língua Portuguesa do Departamento de Letras Clássicas e Vernáculas da Faculdade de Filosofia, Letras e Ciências Humanas da Universidade de São Paulo, para a obtenção do título de Doutora em Letras.

Orientador: Prof. Dr. Silvio de Almeida Toledo Neto

São Paulo

Outubro/2017 
UNIVERSIDADE DE SÃO PAULO

FACULDADE DE FILOSOFIA, LETRAS E CIÊNCIAS HUMANAS

DEPARTAMENTO DE LETRAS CLÁSSICAS E VERNÁCULAS

PROGRAMA DE FILOLOGIA E LÍNGUA PORTUGUESA

ELIZANGELA NIVARDO DIAS

O sinal é este mesmo bilhete: uma tipologia documental para os escritos da roda dos expostos

Tese apresentada ao Programa de Pós-Graduação em Filologia e Língua Portuguesa do Departamento de Letras Clássicas e Vernáculas da Faculdade de Filosofia, Letras e Ciências Humanas da Universidade de São Paulo, para a obtenção do título de Doutora em Letras.

Orientador: Prof. Dr. Silvio de Almeida Toledo Neto

SÃO PAULO 
Autorizo a reprodução e divulgação total ou parcial deste trabalho, por qualquer meio convencional ou eletrônico, para fins de estudo e pesquisa, desde que citada a fonte.

Catalogação na Publicação

Serviço de Biblioteca e Documentação

Faculdade de Filosofia, Letras e Ciências Humanas da Universidade de São Paulo

D541s

Dias, Elizangela Nivardo

o sinal é este mesmo bilhete: uma tipologia documental para os escritos da roda dos expostos / Elizangela Nivardo Dias; orientador Silvio de Almeida Toledo Neto. - São Paulo, 2017. $378 \mathrm{P}$.

Tese (Doutorado) - Faculdade de Filosofia, Letras e Ciências Humanas da Universidade de São Paulo. Departamento de Letras Clássicas e Vernáculas. Área de concentração: Filologia e Língua Portuguesa.

1. Filologia . 2. Diplomática . 3. Tipologia documental. 4. Escritos . 5. Roda dos expostos. I Toledo Neto, Silvio de Almeida, orient. II. Título. 
Nome: DIAS, Elizangela Nivardo

Título: O sinal é este mesmo bilhete: uma tipologia documental para os escritos da roda dos expostos

Tese apresentada ao Programa de Pós-Graduação em Filologia e Língua Portuguesa do Departamento de Letras Clássicas e Vernáculas da Faculdade de Filosofia, Letras e Ciências Humanas da Universidade de São Paulo, para a obtenção do título de Doutora em Letras.

Aprovado em:

Banca Examinadora

Prof. Dr.

Julgamento:

Prof. Dr.

Julgamento:

Prof. Dr.

Julgamento:

Prof. Dr.

Julgamento:

Prof. Dr.

Julgamento:
Instituição:

Assinatura:

Instituição:

Assinatura:

Instituição:

Assinatura:

Instituição:

Assinatura:

Instituição:

Assinatura: 


\section{DEDICATÓRIA}

Dedico esta tese a minha irmã Isabel Nivardo Dias, pela amizade, amor, dedicação, bom exemplo e suporte dados a mim e a nossa família em todo o tempo. 


\section{AGRADECIMENTOS}

Como deve ser, o primeiro agradecimento é a Deus, que é quem nos concede e conserva a vida para perseguirmos nossos propósitos, nos inspirando e coordenando todas as coisas para que sua vontade se cumpra. Aqui estamos por sua permissão.

Ao Prof. Dr. Sílvio de Almeida Toledo, pela erudição e sabedoria - admirada por todos nós envolvidos com a Filologia - e respeito à minha trajetória de vida profissional e acadêmica. Minha eterna gratidão por acreditar em meu potencial acadêmico.

À Profa. Dra. Renata Ferreira Munhoz, pelas orientações e amizade espontânea, generosa e sincera que começou na academia e se estendeu para a vida. Esta é uma pessoa em quem me inspiro e admiro pela bondade, inteligência, rigor científico, dedicação e generosidade ímpares.

Ao Prof. Dr. Phablo Roberto Marchis Fachin, pelas ricas orientações, sugestões e notas detalhadas no exame de qualificação e depois dele.

À Profa. Dra. Vanessa Martins do Monte, admirada por seu carisma, foco, dedicação e nítido amor pelas Letras. Agradeço também pelas sugestões dadas no exame de qualificação.

À Profa. Dra. Renata Ferreira da Costa, que foi um presente valioso que ganhei nesta minha jornada acadêmica.

À minha amiga brasileira-suíça Ana Claudia Keck, pela amizade e colaboração sempre presentes, mesmo à distância.

Aos admiráveis médicos, meus colegas de tempo de FMUSP, que, mesmo afastados fisicamente, admiro pela seriedade, amizade, dedicação e seriedade de suas pesquisas, no trabalho e no trato dos pacientes: Dr. Joaquim Maurício Motta Leal Junior e Edoardo Vattimo. Vocês, suas palavras e exemplos fizeram diferença em minha vida.

Ao Fundo Sasakawa que, por meio do SYLFF (Ryoichi Sasakawa Young Leaders Fellowship Fund), financiou parte deste trabalho, possibilitando que eu dedicasse mais tempo e energia a esta pesquisa.

Aos colaboradores e pesquisadores dos Arquivos históricos das Santas Casas de Misericórdia do Rio de Janeiro, de Salvador e de Lisboa, que fizeram o que Ihes foi possível para me fornecer acesso aos documentos das rodas dos expostos.

À Ingrid Ribeiro Souza, historiadora, responsável técnica pelo acervo do Museu da Santa Casa de São Paulo por sua dedicação, carisma e profissionalismo. Muito sucesso em sua recém iniciada jornada no Museu da Santa Casa de São Paulo e que nosso trabalho conjunto prossiga por muitos anos. 
Às minhas amigas de longa data, Silvana Alves da Silva, Marilda de Fátima Fraga Carvalho, Vanessa Cardoso Marques Cavalcante, Cibele Helena Daher, Valeska dos Santos, por tornarem minha vida mais leve, doce e feliz.

Aos meus amigos da IPI: Gisele e Flavio Faccio, Moacir, Keila e Raquel Carvalho, inspirações para minha vida espiritual.

Aos amigos Ricardo da Silva Carvalho e Diego Bueno Marangoni, que me acompanharam e motivaram em algumas etapas dessa pesquisa.

A todos os amigos e parentes que compreenderam minha vida sobrecarregada e desculparam minha ausência, dentre elas: Claudia Regina Nicoletti, Vera Preto Calado, Lenira Cipriano, Angela Maramaldo Barreiros.

À Camila Igari, coach e amiga que me ensinou a testar, estimular e valorizar o meu "ser-acadêmico" e pela receptividade e apoio às minhas pesquisas em Salvador.

Às amigas que acompanharam, valorizaram meu esforço e me apoiaram em tudo o que precisei: Miriam Raposo Kobi, Euza Carneiro, Rosana Pissutti e Debora Henglen. Pessoas inesquecíveis.

Ao Google, nas pessoas de Thiago Gouveia - com quem tudo começou - Márcio Garcez, Monica Carvalho, Flavia Sekles, minha buddy Lia Romano Palomares, minhas pares Priscila Noronha, Juliana Aliotte e Thaís Cler Correa, que me receberam e me proporcionaram a oportunidade de fazer parte desse ambiente excepcional.

À minha doce mãe, Judith Nivardo Dias, exemplo de amabilidade, fé e sabedoria divina.

Ao meu irmão Eliseu Nivardo Dias, por me ajudar a cuidar de nossa família.

Ao meu amado Carlos Zibordi, por estar ao meu lado em todas as circunstâncias, por mostrar que está comigo especialmente nos piores momentos, nas horas de medo e dúvida, por respeitar e perdoar meus erros e por ter mudado minha vida. Sou feliz por estarmos juntos nesta jornada. TL! 
Ainda naõ está baptizado: pede-se que se lhe ponha João Cancio: o signal

he este mesmo bilhete.

Escrito 3 - Santa Casa de Misericórdia de Lisboa, 1790 


\section{RESUMO}

DIAS, Elizangela Nivardo. O sinal é este mesmo bilhete: uma tipologia documental para os escritos da roda dos expostos. 2017. 378p. Tese (Doutorado em Filologia e Língua Portuguesa). São Paulo: Faculdade de Filosofia, Letras e Ciências Humanas, Universidade de São Paulo, São Paulo, 2017.

Esta tese estuda, a partir de uma perspectiva filológica, os escritos que acompanhavam as crianças depositadas anonimamente na roda dos expostos, para que fossem criadas pelas Misericórdias. A partir de pesquisas de campo em quatro arquivos, localizados nas Santas Casas de Misericórdia de São Paulo, Salvador, Rio de Janeiro e Lisboa, constituímos um corpus de 60 escritos, com datas entre 1790 e 1923. Examinamos o contexto de circulação desses escritos, a definição de termos frequentes e/ou próprios do estudo das rodas dos expostos e tratamos dos contextos institucional, jurídico e histórico das rodas dos expostos. Apresentamos a reprodução fac-similar, a transcrição semidiplomática do corpus da pesquisa e a descrição codicológica dos escritos. Por meio da análise diplomática do corpus, examinamos os elementos extrínsecos e intrínsecos que o caracterizam. A presença de sinais, que permitiriam o resgate futuro da criança depositada, é própria dos escritos da roda. Há vários sinais nos escritos do corpus, os quais podem ser tanto elementos textuais como não-textuais. Dividimos o estudo do texto dos escritos em duas partes principais: a expositio, na qual o autor fornece as informações sobre o exposto que considera importantes (o nome da criança, a data de nascimento e o fato de a criança estar ou não batizada); e a dispositio, em que o autor manifesta suas vontades e intenções ao destinatário (de maneira geral, relacionadas aos sinais e ao resgate da criança). A partir do estudo tipológico, concluímos que grande parte dos escritos da roda corresponde à espécie documental carta, tanto em sua função quanto em sua forma. Observamos também a ocorrência, em menor número, de outros padrões tipológicos, que correspondem ao poema, à narrativa, e à lista de dados. Embora haja alteração da forma, nos quatro tipos de escrito identificados sempre constam as informações essenciais sobre o exposto. Essa regularidade nos escritos da roda revela que, mesmo não se tratando de documentos oficiais, os escritos da roda apresentam-se como documentos informais de identificação da criança. Apesar de não haver fórmulas oficialmente prescritas, os escritos apresentam, por padrões inferidos, uma prática tipológica que se caracteriza como parte da cultura da roda.

Palavras-chave: Filologia. Diplomática. Tipologia documental. Escritos. Roda dos expostos. 


\begin{abstract}
DIAS, Elizangela Nivardo. This note is the signal: a document typology for the writings of the foundling wheels. 2017. 378p. Thesis (Ph.D.). São Paulo: "Faculdade de Filosofia, Letras e Ciências Humanas, Universidade de São Paulo", 2017.

Based on a philological perspective, this dissertation has studied the writing notes that accompanied the babies anonymously left at the Foundling Wheels to be raised by the charitable hospitals Misericordias (Holy Houses of Mercy). Conducting field research studies of four files at Santa Casa de Misericordia in Sao Paulo, Salvador, Rio de Janeiro, and Lisbon, we have built a corpus of 60 writing notes dated from 1790 to 1923. We have examined the context of circulation of said writings, the definition of frequent and/or proper terms from Foundling Wheels studies and considered the institutional, legal and historical background of the Foundling Wheels. We present the fax-simile reproduction, the semi-diplomatic transcription of the documents and the codicological description of the notes. Based on the diplomatic analysis of the corpus, we have examined the intrinsic and extrinsic elements that characterize them. The presence of signals that would enable future reclaim of the abandoned child is part of the writings found in the Wheels. There are many indications in the corpus writings, which may include textual and non-textual elements. We have divided the study of the writings into two main parts: expositio, in which the author provides information about the foundling (name of the child, date of birth, and whether the child had been baptized), and dispositio, in which the author states her/ his wills and intentions to the recipient (generally related to the signals and the child future reclaim). Based on typology studies, we have concluded that most of the writings from the Wheel corresponded to the document type letter, both in its function and format. We have also observed less frequent examples of other typological formats, such as poems, narratives, and lists. Even though the format is different, all four identified types included some essential information about the foundlings. This regularity of the Wheels' writings indicates that, even though they were not official documents, these writings served as informal identification documents of the children. Although there are no officially prescribed formulas, we can infer that these writings have a typology that is characterized as part of the Foundling Wheel culture.
\end{abstract}

Key words: Philology. Diplomatics. Document typology. Writings. Foundling wheel. 


\section{LISTA DE SIGLAS}

AH-SCML Arquivo Histórico da Santa Casa de Misericórdia de Lisboa

CE Casa dos expostos

CMJC-SCMBA Centro de Memória Jorge Calmon, da Santa Casa de Misericórdia da Bahia

ERD-SCMRJ Educandário Romão Duarte, da Santa Casa de Misericórdia do Rio de Janeiro

IPHAN Instituto do Patrimônio Histórico e Artístico Nacional

MSC-SP Museu da Santa Casa de Misericórdia de São Paulo

$\mathrm{SCM}$

Santa Casa de Misericórdia

SCMB Santa Casa de Misericórdia da Bahia

SCML Santa Casa de Misericórdia de Lisboa

SCMRJ Santa Casa de Misericórdia do Rio de Janeiro

SCMSP Santa Casa de Misericórdia de São Paulo 


\section{LISTAS DE FIGURAS}

Figura 1 - Manuscrito com pobreza como razão do abandono da criança; AH-SCML, 1892

Figura 2 - Manuscrito com justificativa de entrega da criança; AH-SCML, 1892 22

Figura 3 - Escrito com pedaço de tecido costurado AH-SCML, 1850 23

Figura 4 - Escrito com suporte em formato de coração - frente e verso, AHSCML, 1890

Figura 5 - Organograma da composição geral da Mesa dos Expostos. 26

Figura 6 - Organograma funcional geral da Casa dos Expostos 27

Figura 7 - Página de rosto do Código Penal Português, Lisboa: Imprensa Nacional, 1855

Figura 8 - Página da Secção 4 - Exposição e abandono dos infantes, Código Penal Português, Lisboa: Imprensa Nacional, 1855

Figura 9 - Registro de entrada do exposto Jorge Gomes de Jesus, com identificação da mãe, acompanhado de escrito,1958

Figura 10 - Roda dos expostos da SCMBA .55

Figura 11 - Livro de registro dos enjeitados, aberto, CMJC-SCMBA, 17571763 66

Figura 12 - Roda dos expostos da SCMRJ ........................................... 67

Figura 13 - Escritos encadernados, ERD-SCMRJ, 1876 68

Figura 14 - Roda da SCMSP sobre estante contendo livros de matrícula dos expostos.

Figura 15 - Registro de entrada de exposto exibindo o escrito correspondente,

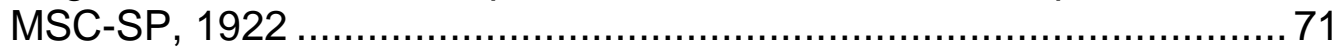

Figura 16 - Capa de livro de matrícula de expostos da MSC-SP, $1915 \ldots \ldots \ldots \ldots \ldots .72$

Figura 17 - Página de matrícula de exposta acompanhada de escrito redigido em língua Italiana e sinais, MSC-SP, 1915 .................................. 73

Figura 18 - Modelo de ficha codicológica .................................................. 215

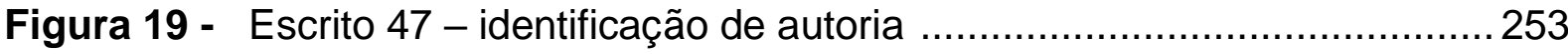




\section{LISTA DE GRÁFICOS}

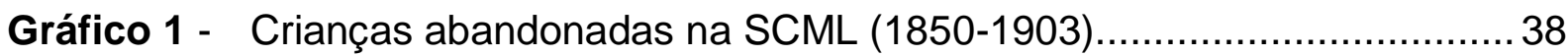

Gráfico 2 - Variação da composição do suporte de escrita .................................... 240

Gráfico 3 - Variação do formato do suporte de escrita .................................243

Gráfico 4 - Elementos anexados ao suporte de escrita .............................. 246

Gráfico 5 - Presença de acréscimos ao texto no corpus ...............................248

Gráfico 6 - Marcas de identificação de destinatário no corpus ..........................251

Gráfico 7 - Utilização de assinatura para identificar o autor ........................... 254

Gráfico 8 - Utilização de iniciais para identificar o autor ............................... 255

Gráfico 9 - Utilização do nome para identificar o autor................................. 256

Gráfico 10 - Gênero dos expostos do corpus............................................262

Gráfico 11 - Marcas de identificação do exposto no corpus: nome .....................264

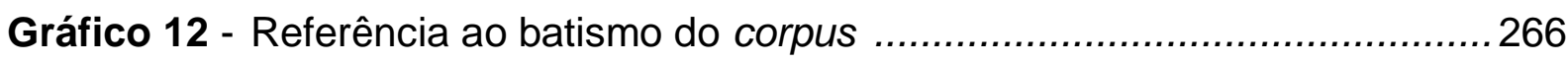

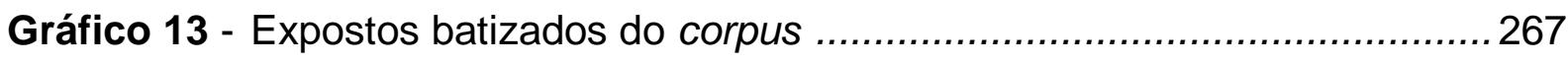

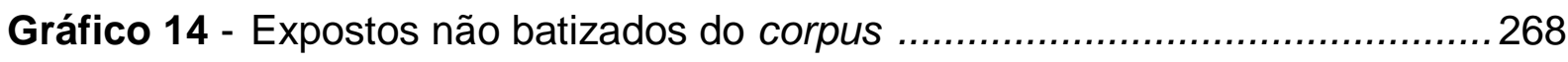

\section{LISTA DE TABELAS}

Tabela 1 - Número absoluto de expostos deixados na Roda da SCMRJ, 1738-1797...

Tabela 2 - Proporção entre população e número de expostos deixados na Roda da SCMRJ, 1738-1797 


\section{LISTA DE QUADROS}

Quadro 1 - Datas de instalação das rodas dos expostos no Brasil...................... 40

Quadro 2 - Legislação brasileira relativa à proteção de menores ......................... 49

Quadro 3 - Local e instituição de origem dos escritos do corpus.........................74

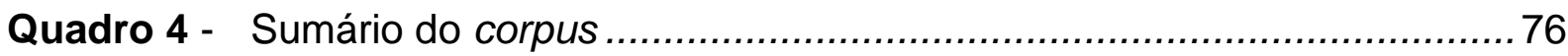

Quadro 5 - Escritos agrupados de meio em meio século .................................. 83

Quadro 6 - Variação na composição do suporte de escrita ................................ 239

Quadro 7 - Variação do formato do suporte de escrita ..................................... 241

Quadro 8 - Descrição dos elementos anexados ao suporte de escrita ................244

Quadro 9 - Tipos de sinais anexados ao suporte de escrita ............................ 245

Quadro 10 - Descrição dos acréscimos ao texto encontrados no corpus ..............247

Quadro 11 - Tipos de acréscimos ao texto encontrados no corpus ......................247

Quadro 12 - Marcas de identificação do destinatário encontradas no corpus........ 251

Quadro 13 - Marcas de identificação do autor encontradas no corpus.................. 253

Quadro 14 - Datação tópica e cronológica dos escritos do corpus ....................... 257

Quadro 15 - Referência à data de nascimento do exposto nos escritos do corpus ........................................................................... 260

Quadro 16 - Lista exaustiva de nomes das crianças do corpus ..........................263

Quadro 17 - Lista exaustiva de menções ao batismo no corpus .........................265

Quadro 18 - Formulação da expositio dos escritos da roda com os verbos nascer, entrar e ir ............................................................269

Quadro 19 - Formulação da expositio dos escritos da roda com os verbos entregar, botar, remeter, deixar e por ...................................... 270

Quadro 20 - Menção ao sinal nos escritos do corpus .......................................273

Quadro 21 - Convergência de elementos extrínsecos e intrínsecos nos escritos do corpus ............................................................................ 276

Quadro 22 - Classificação tipológica dos escritos do corpus ..............................292 


\section{SUMÁRIO}

1 INTRODUÇÃO 17

2 OS DOCUMENTOS E AS RODAS DOS EXPOSTOS …....................................19

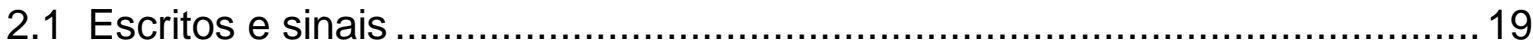

2.2 Aspectos institucionais, jurídicos e históricos ………………………….... 26

3 ORIGEM, DESCRIÇÃO E TRANSCRIÇÃO DO CORPUS .................................63

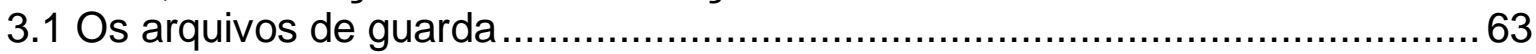

3.1.1 Arquivos de guarda dos documentos da Roda de Lisboa ...................63

3.1.2 Arquivo de guarda dos documentos da Roda de Salvador ...................65

3.1.3 Arquivo de guarda dos documentos da Roda de Rio de Janeiro............66

3.1.4 Arquivo de guarda dos documentos da Roda de São Paulo ................. 70

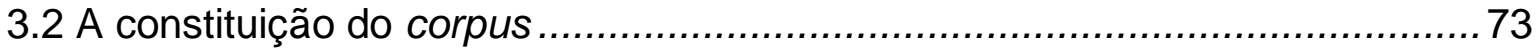

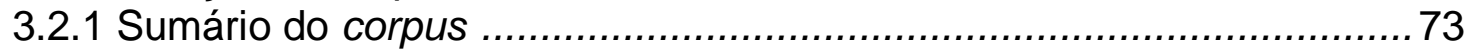

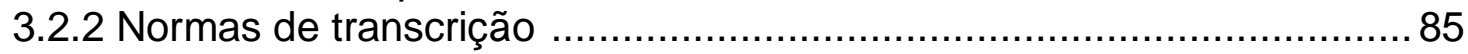

3.2.3 Reprodução fac-similar e transcrição semidiplomática .........................87

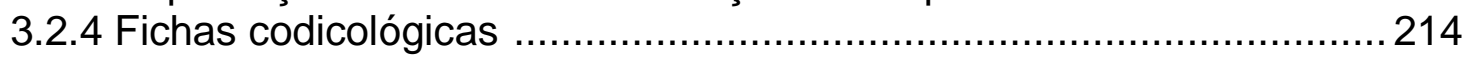

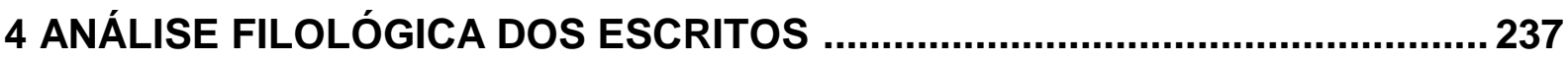

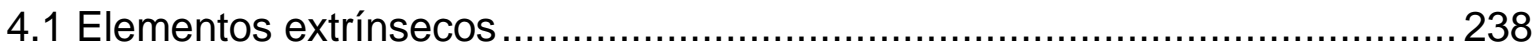

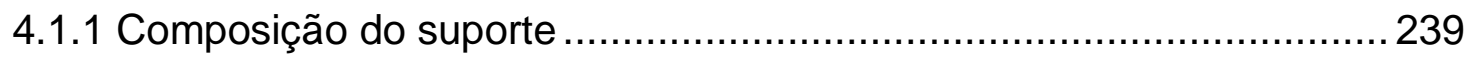

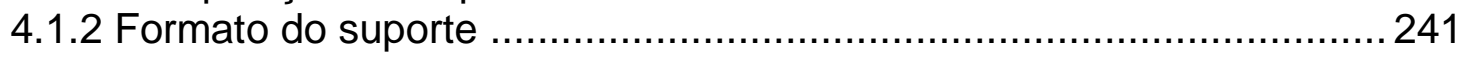

4.1.3 Elementos anexados ao suporte: sinais ....................................... 243

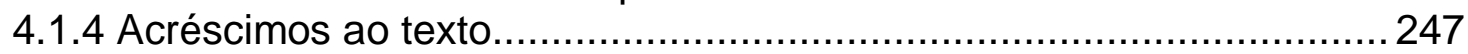

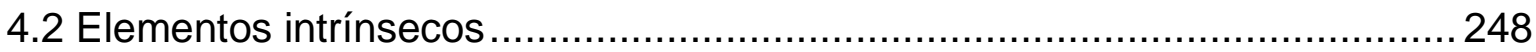

4.2.1 Protocolo inicial dos escritos da Roda ........................................ 249

4.2.2 Protocolo final: identificação do autor ............................................ 252

4.2.3 O texto dos escritos da Roda: Exposição (narratio) .......................... 258

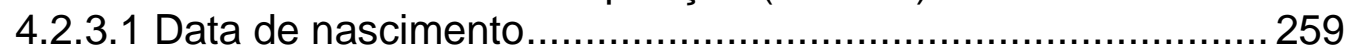

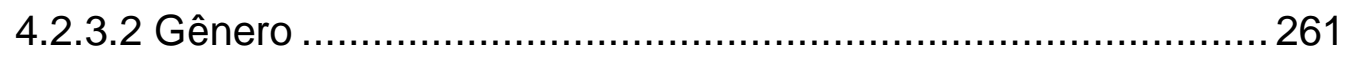

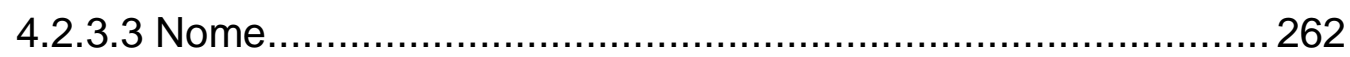

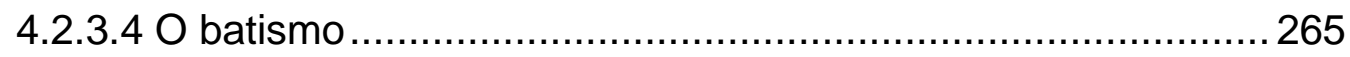

4.2.3.5 Formulação da expositio dos textos ……………………... 269

4.2.4 O texto dos escritos da Roda: Dispositivo (dispositio) ........................2271

4.2.4.1 Formulação da dispositio dos textos................................... 272

4.2.4.2 Referência aos sinais na dispositio dos textos ..................... 272

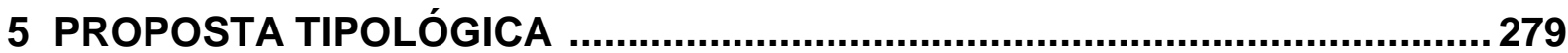

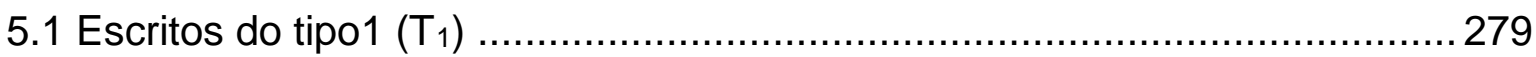

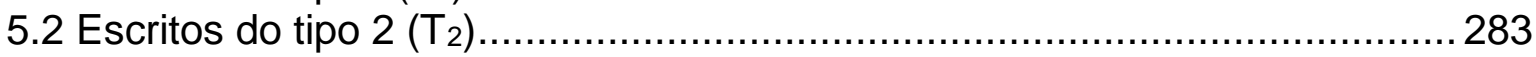

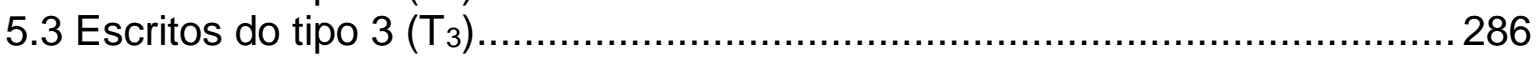

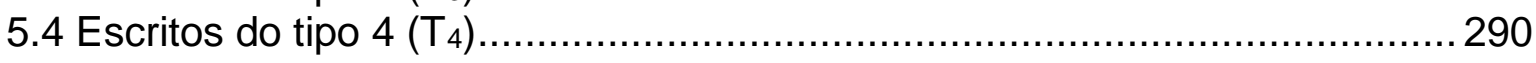

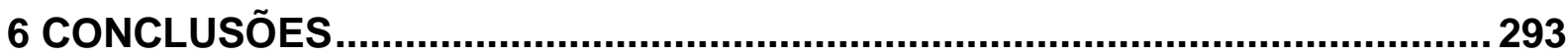




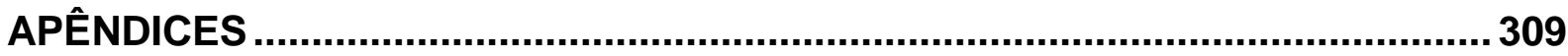

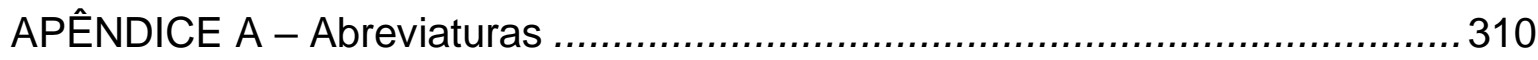

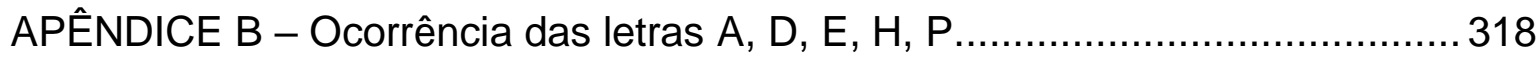

APÊNDICE C - Variação caligráfica entre os escritos (punhos) ..........................332

APÊNDICE D - Índice de termos relacionados à exposição de crianças ........... 335

APÊNDICE E - Índices de termos relacionados aos sinais e ao enxoval............340

APÊNDICE F - Mais alguns exemplos de escritos da roda (Lisboa e Rio de

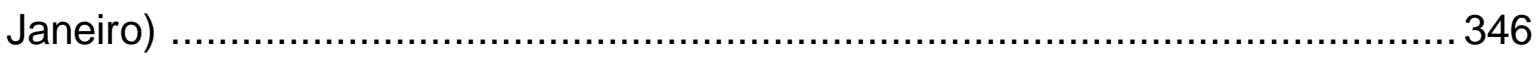

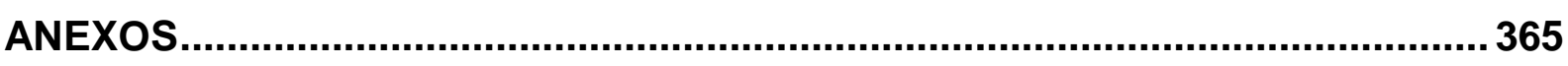

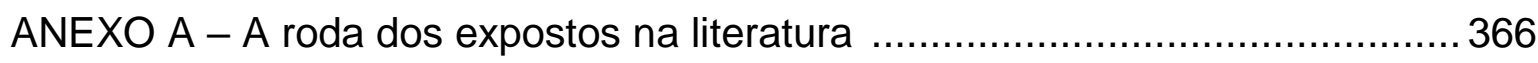

ANEXO B - Reprodução da pintura da visita de D. Pedro II e D. Leopoldina a roda

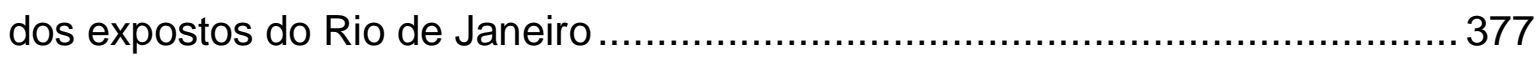




\section{INTRODUÇÃO}

O objetivo desta pesquisa é estudar, a partir de uma perspectiva filológica, os escritos que acompanhavam as crianças depositadas na roda dos expostos. A roda dos expostos era, um mecanismo cilíndrico de madeira, no qual bebês podiam ser deixados anonimamente, para que fossem criados pelas Misericórdias, por um período de tempo indeterminado.

A primeira etapa desta pesquisa realizou-se como trabalho de campo. Visitamos diferentes Misericórdias no Brasil e em Portugal. Selecionamos e reproduzimos um grande número de escritos, a partir dos quais compusemos nosso corpus a partir do critério cronológico e geográfico. Em seguida, à seleção do corpus, fizemos a transcrição dos escritos selecionados.

Os escritos estudados provêm de quatro diferentes Misericórdias, localizadas nas seguintes cidades: São Paulo, Rio de Janeiro, Salvador e Lisboa. A escassez de material encontrado em São Paulo motivou-nos a ampliar a pesquisa para as antigas capitais coloniais do Brasil, Salvador e Rio de Janeiro, e à capital do reino, Lisboa. A partir do levantamento e seleção, compusemos um corpus de 60 escritos, com datas entre 1790 e 1923, portanto, o corpus apresenta-se heterogêneo, por conter material produzido em distintos locais e períodos.

Conforme uma perspectiva filológica, procuramos, inicialmente, identificar as principais características codicológicas e paleográficas do corpus: datação tópica e cronológica, tipo e o formato do suporte material empregado.

Os escritos da roda dos expostos apresentam diversos elementos de interesse para o filólogo. Por exemplo, os sinais, elementos de identificação anexos aos escritos. É um elemento que, embora não textual, tem um peso na caracterização diplomática de alguns dos escritos. Assim, por meio da análise diplomática do corpus, examinaremos os elementos extrínsecos e intrínsecos que o caracterizam. Neste caso, o propósito, é verificar que tipologia ou tipologias documentais são seguidas na elaboração dos escritos do ponto de vista diplomático, é um aspecto muito importante, para onde convergem todos os elementos estudados nesta pesquisa. Saber se os escritos compõem tipos heterogêneos ou apenas um modelo é uma questão fundamental e norteadora deste estudo, à medida que constatamos que a caracterização diplomática desses escritos da roda é muito escassa, para não dizer 
inexistente. A ausência de estudos diplomáticos sobre esses escritos justifica em grande parte nosso estudo, que se espelha nas funções do trabalho filológico propostas por Spina (1977, p.77).

Esta pesquisa divide-se em quatro partes. Na primeira parte, procuramos conceituar o que são os escritos da roda. Examinamos o contexto de circulação desses escritos e a definição de termos frequentes e/ou próprios do estudo das rodas dos expostos, como o próprio termo exposto, além de enjeitado, depositante e sinais. Tratamos também dos contextos institucional, jurídico e histórico das rodas dos expostos e das instituições que acolheram as crianças e arquivaram os escritos.

$\mathrm{Na}$ segunda parte, apresentamos a reprodução fac-similar e a transcrição semidiplomática do corpus da pesquisa. Examinamos a origem dos documentos e descrevemos os arquivos que preservam os originais e as condições de manutenção dos mesmos. Apresentamos as normas de transcrição e concluímos com a descrição codicológica do corpus.

$\mathrm{Na}$ terceira parte, procedemos a uma análise filológica, mais especificamente diplomática, dos escritos da roda. Partimos da premissa que as características formais do documento são determinadas pelas circunstâncias de sua elaboração, pelo grau de cultura daqueles que os redigem, pelos meios de que dispõem para elaborá-los e pelo teor daquilo que necessitam registrar. Analisamos elementos extrínsecos e intrínsecos dos escritos.

Na quarta e última parte, fazemos a proposta de uma tipologia dos escritos da roda dos expostos. Investigamos as semelhanças e diferenças codicológicas, paleográficas e diplomáticas apresentadas nos capítulos anteriores. 


\section{OS DOCUMENTOS E AS RODAS DOS EXPOSTOS}

$\mathrm{Na}$ primeira parte deste capítulo, caracterizamos, os escritos da roda dos expostos $^{1}$. Em seguida, examinamos o contexto de circulação desses escritos. Procuramos ainda apresentar uma definição de termos ${ }^{2}$ recorrentes no campo semântico referente à roda dos expostos: exposto, enjeitado e depositante. Examinamos também os sinais que acompanham os escritos.

$\mathrm{Na}$ segunda parte deste capítulo, apresentamos brevemente os contextos institucional, jurídico e histórico das rodas dos expostos e das instituições que acolheram as crianças e arquivaram os escritos ${ }^{3}$.

\subsection{ESCRITOS E SINAIS}

Nosso passo inicial foi delimitar um grupo documental específico, reunindo os manuscritos das rodas dos expostos denominados escritos da roda. Este conjunto de documentos é constituído, exclusivamente, por escritos depositados junto às crianças nas rodas, porém, produzidos previamente, fora das instituições. Originalmente, tais manuscritos fazem parte de um grupo indiferenciado e heterogêneo de documentos encontrados nos arquivos das instituições que acolheram os expostos e que incluem livros de registros, livros de receitas e despesas, certidões de batismo, certidões de nascimento, laudos médicos e outros.

Para delimitar nosso corpus, o passo inicial foi, então, selecionar um conjunto de escritos da roda dos expostos. Estes escritos acompanhavam as crianças depositadas na roda. $E$, nas instituições que os recebiam, eram um dos tipos de

\footnotetext{
${ }^{1}$ As "rodas dos expostos" eram mecanismos cilíndricos de madeira, instalados em muros ou paredes de instituições para possibilitar o depósito anônimo de crianças, ali deixadas para serem acolhidas. $\mathrm{O}$ procedimento de uso era o seguinte: a criança era colocada no interior do cilindro, que era girado 180 graus, de modo que a parte onde a criança era depositada virava-se para o interior do prédio. Isto feito, a campainha, ou o sino, era tocada pela pessoa que ali deixava a criança. O funcionário da casa, ao escutar o toque, dirigia-se até o muro para retirar a criança e providenciar o registro de seu recebimento.

2 Utilizamos como referências: Bluteau (1722), Venâncio (1999) e Manoel (2001, 2006, 2010). A definição de termos é fundamental para tornar mais preciso e completo o entendimento e a posterior análise filológica e diplomática dos textos dos escritos. Como apêndice deste trabalho há um índice de termos da roda dos expostos, que traz outros termos referentes ao assunto.

3 São referências para essa parte a Compilação das leis relativas aos expostos (1820) e o Código de Menores, de Mello Matos (1927). O estudo das leis relativas aos expostos e à proteção de menores fornece informações imprescindíveis para compreender certos procedimentos e perceber alterações importantes na produção dos escritos, as quais estão correlacionadas com a sua datação cronológica.
} 
manuscritos que trarão informações sobre a criança. Há ainda muitos outros, como os livros de registro, os livros de receitas e despesas, as certidões de batismo, as certidões de nascimento e os laudos médicos, entre outros.

Na bibliografia consultada, esses escritos são denominados, de forma geral, como bilhetes ou cartas. No entanto, constatamos que essa denominação geral é imprecisa, uma vez que há mais de uma forma para a execução do texto. Propomos, portanto, o termo escritos, seguindo a nomenclatura adotada por Manoel e Morna ${ }^{4}$ (2001, p.111) que assim se referem aos papeis manuscritos que acompanhavam a criança exposta. Conforme os autores, escrito era o "texto através do qual os pais, ou alguém de sua confiança, transmitiam as informações consideradas pertinentes".

Exposto ou enjeitado do passado são as crianças abandonadas de hoje (VENÂNCIO, 1999, p. 19). Enjeitado, de acordo com Bluteau (Suplemento, parte I, 1722, p. 577), era o "desamparado de seus pays, e exposto no adro de huma Igreja (...), ou de pessoa particular, ou depositado no campo a Deos". Outras denominações eram empregadas para denominar a criança depositada na roda dos expostos: inocente, anjinho, imposto, infeliz são utilizados em diversos contextos como sinônimos para fazer referência à criança deixada na roda 5 .

Retomando o foco aos escritos da roda dos expostos, já que definimos os termos, escritos e expostos, acrescentamos que, embora a forma do escrito seja variada, o conteúdo é recorrente. As informações que sempre constam, ou poderiam constar, nos escritos são as seguintes, conforme Manoel (2006, p.79):

- Data e hora de nascimento;

- Nome pretendido;

- Referência ao fato de a criança já ter sido batizada, ou

- Demonstração expressa do desejo de que seja batizada;

- Pedido específico para a criança ser bem tratada;

- Explicação sobre as razões que levaram à exposição do descendente;

- Descrição das características físicas ou de seu estado de saúde;

- Relação do enxoval que acompanhava o bebê;

\footnotetext{
${ }^{4}$ Francisco d'Orey Manoel e Teresa Freitas Morna, são, respectivamente, Diretor do Arquivo Histórico da Santa Casa de Misericórdia de Lisboa e Conservadora do Museu São Roque.

${ }^{5}$ Neste trabalho adotamos o termo exposto para a criança deixada na roda, depositante, para quem deixa a criança na roda anonimamente e depositar, para o ação de deixar a criança na roda.
} 
- Solicitação para não entregar a criança a uma ama residente fora de Lisboa;

- Nota referindo a intenção de recuperar o filho logo que tal viesse a ser possível e

- Indicação de outros elementos considerados pertinentes.

Dentre os tópicos referidos, um dos mais importantes do ponto de vista social e histórico é o que menciona as razões do abandono. As principais razões alegadas para o depósito na roda, conforme pudemos constatar, eram a incapacidade de cuidar da criança, por motivo de doença dos pais ou responsáveis, ou por falta de recursos. Um exemplo da justificativa por falta de recursos registra-se no escrito a seguir. A autora define-se como "uma mãe extremosa mas muito pobre":

Figura 1 - Manuscrito com pobreza como razão do abandono da criança; AH-SCML, 1892

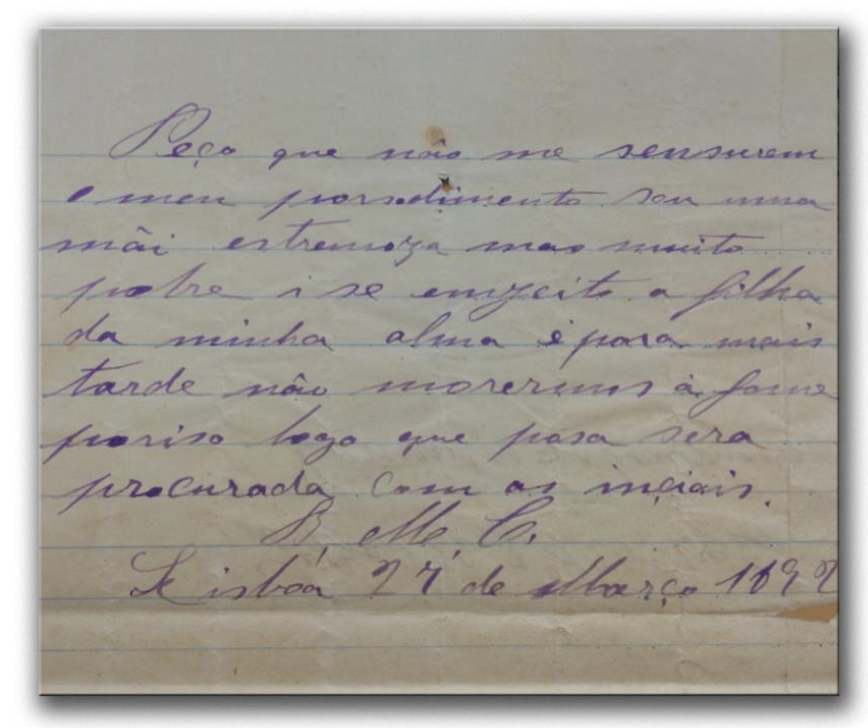

Peço que nâo me sensurem o meu porsedimento sou uma mãi estremoza mas muito pobre i se emjeito a filha da minha alma é para mais tarde nâo morermos à fome poriso logo que posa sera procurada com as iniçiais. B.M.C.

Lisboa 27 de Março de 189[2].

Havia ainda outras razões para o abandono do exposto, como a necessidade política, como evidencia o exemplo a seguir - no entanto, não cabe ao escopo deste estudo investigar qual necessidade política seria essa. 
Figura 2 - Manuscrito com necessidade política como razão do abandono da criança; AH-SCML, 1800

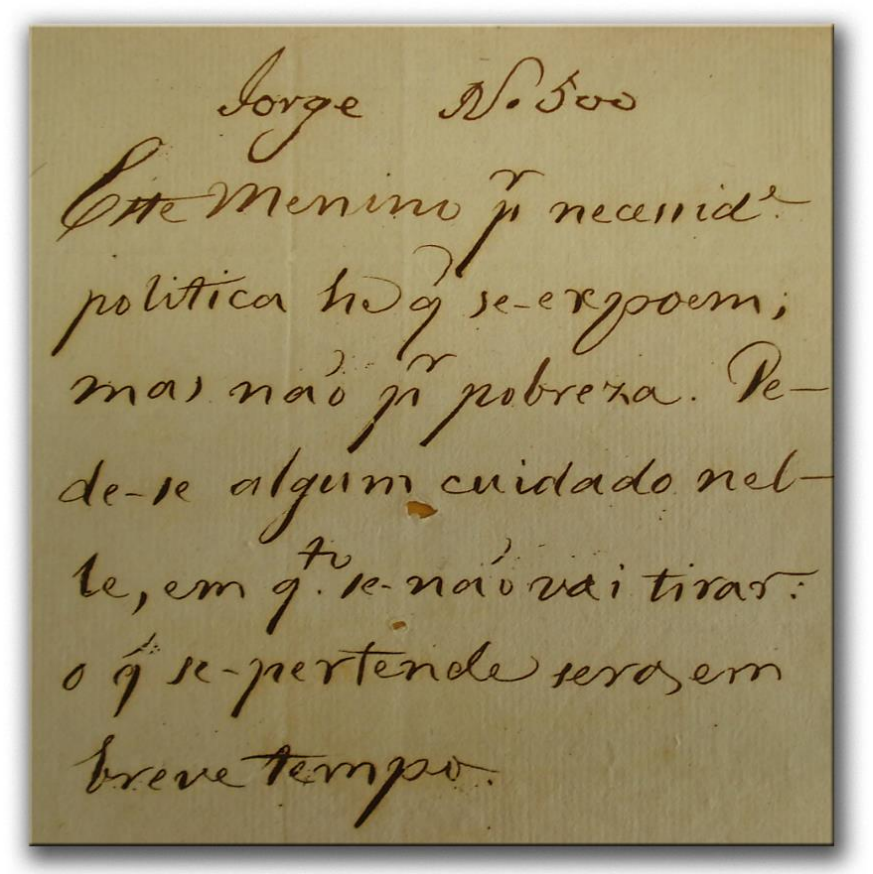

Jorge <Número 500>

Este menino por necessidade politica he que se-expoem; mas não por pobreza. Pede-se algum cuidado nele, em quanto se-não vai tirar: o que se-pertende sera em breve tempo.

Entretanto, a legislação relativa aos expostos reconhece como razões que levam os responsáveis a enjeitar as crianças, além da extrema pobreza, a necessidade de ocultar sua origem e a falta de interesse dos pais em relação às crianças, que consideram sua criação um encargo do qual procuram se desincumbir 6 .

Além da forma e do conteúdo textuais, uma particularidade dos escritos da roda é a presença de sinais para indicar a intenção de reclamar a criança posteriormente. Como ensina Rodrigues (1987, p. 8), "o modo de identificar o Exposto visando uma futura recuperação ou a manifestação de um liame originário é impreciso e inicia-se com a aposição à criança abandonada de documentos (...) que marquem sua origem".

$\mathrm{Na}$ bibliografia sobre os escritos da roda, o termo sinal pode designar tanto manifestações dos autores nos textos dos escritos como objetos deixados na roda junto às crianças. Bluteau (1789, t. II, p. 402) define sinal como "qualquer coisa da qual vimos em conhecimento de outra com que ella tem connexão natural”. Há sinais que são elementos de identificação anexos aos escritos ou variações relacionadas ao suporte da escrita. Podem consistir, por exemplo, de pedaços de tecido costurados

\footnotetext{
${ }^{6}$ A Compilação das leis relativas aos expostos, (PINTO, 1820, p. 7) relaciona três razões principais que levavam os progenitores a enjeitar as crianças: 1: Os perigos que corriam se sua origem fosse conhecida, como no caso de crianças fruto de uniões clandestinas; 2: A suma pobreza dos pais; 3: A perversidade dos pais, que sufocam em seus corações o sentimento de amor paterno e lhes faz considerar a criação dos filhos como um peso do qual procuram aliviar-se.
} 
ou colados, fitas perpassadas no papel, ou mesmo alterações no formato do escrito. O escrito reproduzido abaixo apresenta um pedaço de tecido colado ao papel como sinal.

Figura 3 - Escrito com pedaço de tecido costurado AH-SCML, 1850

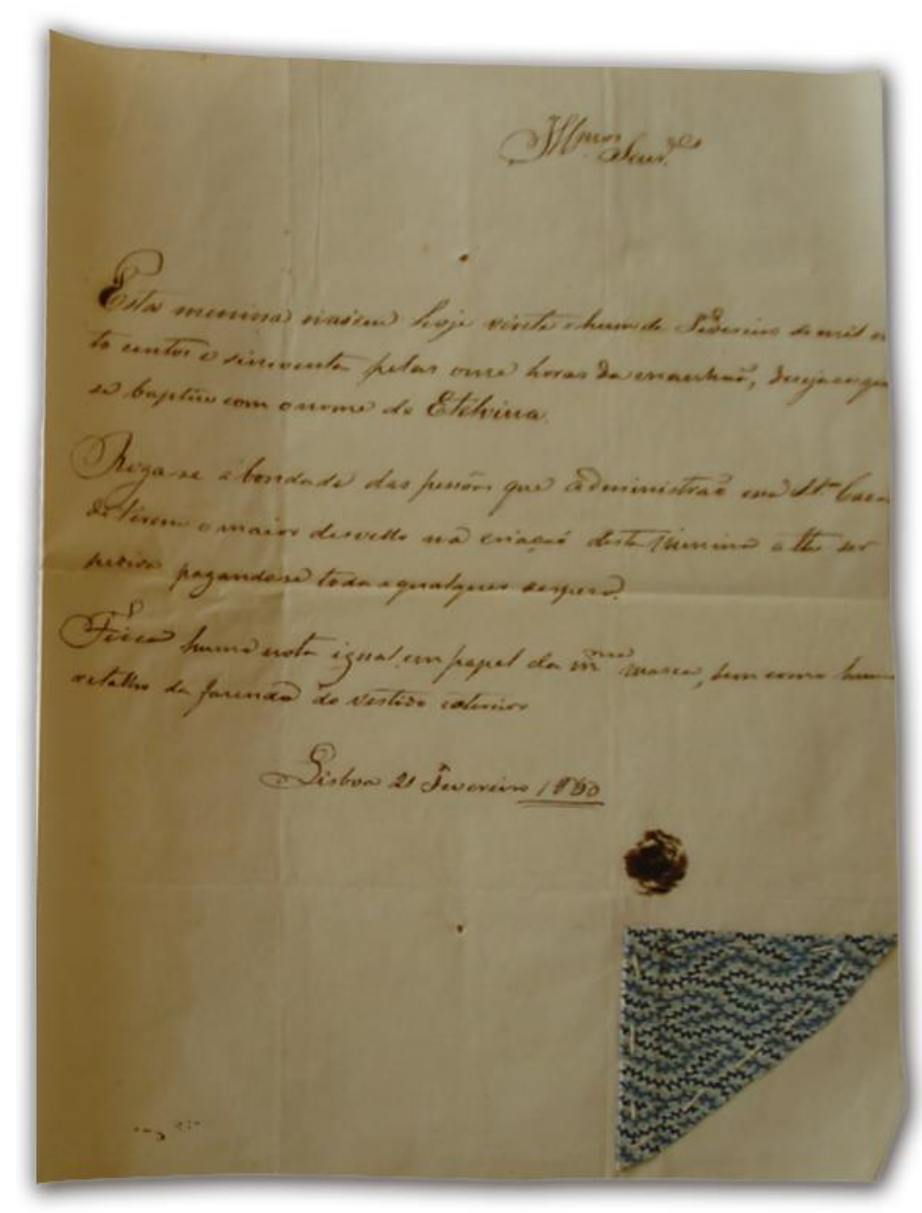

Ilustríssimos Senhores

Esta menina nasceu hoje vinte e hum de Fevereiro de mil oi to centos e sincoenta pelas onse horas da manhaã, deseja se que se baptise com o nome de Etelvina.

Roga-se á bondade das pessôas que administraõ essa Santa Caza de terem o maior desvello na criação desta Minina a the ser preciso pagando se toda e qualquer despesa.

Fica huma nota igual em papel da mesma marca, bem como hum retalho da fadenda do vestido e [coterier ${ }^{7}$ ]

Lisboa 21 de fevereiro de $\underline{\underline{1850}}$

\footnotetext{
${ }^{7}$ Supomos que se seja forma variante de cotelê
} 
Em um exemplo, reproduzido no escrito abaixo, podemos observar como a forma de coração do suporte parece indicar um nexo afetivo entre os responsáveis e o exposto.

Figura 4 - Escrito com suporte em formato de coração, AH-SCML, 1890

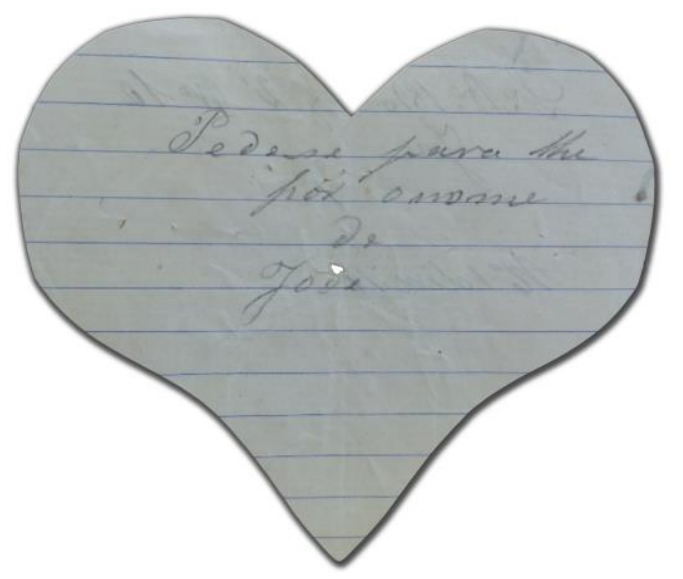

Pede-se para lhe pór o nome de José

O termo sinal também pode referir-se ao próprio texto. Caso houvesse uma cópia do escrito em poder do depositante ou do responsável pela criança, o próprio escrito poderia servir como sinal. Como esclarecem Manoel e Morna (2001, p. 111), "em muitas ocasiões (...) os pais permaneciam com um exemplar igual e, por vezes, chegavam mesmo a inserir cortes no documento, para que o encaixe das duas partes comprovasse a autenticidade dos exemplares".

O autor do escrito também poderia efetuar recortes no suporte do escrito, para que as partes faltantes pudessem servir como sinal. Por vezes, estes recortes eram realizados nas partes dos escritos que continham as assinaturas, dividindo-as ao meio.

Os escritos, ora estudados, eram depositados na roda, junto às crianças, de forma anônima, não obrigatória e sem regulação legal. Não há, até o momento, elementos suficientes para identificar sem qualquer dúvida quem seriam os autores intelectuais e os materiais dos escritos. Seriam sempre os pais ou responsáveis pelas crianças?

Pode-se até mesmo formular a hipótese de os escritos terem sido redigidos por pessoas especializadas em produzir esse tipo de escrito. A questão da autoria será problematizada no decorrer deste estudo, por meio da análise filológica dos escritos do corpus desta pesquisa. 
Do ponto de vista diplomático, embora não sejam obrigatórios e anônimos (em sua maioria), os escritos da roda pretendem ser documento comprobatório, um "atestado de origem da criança", um substituto da certidão de batismo ou do registro civil. Efetuam uma transferência da responsabilidade dos pais ou responsáveis não só da guarda da criança para as Misericórdias, mas são também uma forma de garantir o direito ao nome/registro civil/batismo da criança.

Para realizar uma análise dos escritos, partimos do pressuposto de que os escritos da roda podem ser considerados atos jurídicos, e, portanto, documentos ${ }^{8}$, pois tudo o que está na esfera do funcionamento das rodas constitui uma prática dirigida a uma instituição.

Mesmo sendo um documento, as suas partes não estão explicitadas a priori, mas explicitá-las é exatamente o objetivo de nosso estudo. Por meio de um estudo comparativo, que examina filologicamente diversos escritos provenientes de lugares e épocas distintas, buscaremos definir sua estrutura diplomática. Como afirma Duranti, as regras de cada parte do documento podem ser "fórmulas, estilo burocrático ou literário, linguagem especializada, técnicas de entrevista e assim por diante."9

O exame filológico dos escritos da roda será um meio para o melhor conhecimento desses documentos. É relevante ressaltar que, conforme o ensinamento de Duranti, "essas regras, que chamamos de forma, refletem estruturas políticas, legais, administrativas e econômicas, a cultura, os hábitos, os mitos e constituem uma parte integral do documento escrito". ${ }^{10}$

\footnotetext{
8 Para Duranti, documento é o escrito que "contém informação transmitida ou descrita por meio de regras de representação que são, elas próprias, evidência da intenção de revelar informações" (DURANTI, 1989, p. 15).

${ }^{9}$ Any written document in the diplomatic sense contains information transmitted or described by means of rules of representation, which are themselves evidence of the intent to convey information: formulas, bureaucratic or literary styles, specialized language, interview technique, and so on. (DURANTI, 1989, p. 15).

10 These rules, which we call form, reflect political, legal, administrative, and economic structures, culture, habits, myths, and constitute an integral parto $f$ the written document, because they formulate or condition the ideas or facts which e take to be the contente of the documents. (DURANTI, 1989, p. 15)
} 
2.2 ASPECTOS INSTITUCIONAIS, JURÍDICOS E HISTÓRICOS

Diante da proposta precípua desta tese, de estudar mais detidamente os escritos depositados com os bebês nas rodas dos expostos, torna-se válida a contextualização dos aspectos institucionais, jurídicos e históricos das rodas.

A Administração da Casa da roda no século XVIII era feita pela Mesa dos Expostos. O presidente da mesa era o provedor da Santa Casa, que também era responsável pela administração do hospital. O segundo posto era do escrivão, responsável pelos livros de receitas e de despesas. A seguir estava o tesoureiro, encarregado de cobrar as rendas e esmolas e determinar os dias de pagamento das serventes e amas contratadas. Nenhum dos componentes da Mesa dos Expostos entrava em contato direto com as crianças. Estes três membros da mesa eram classificados como de condição maior ou nobres. No entanto, havia outros escolhidos entre membros de condição menor designados como oficiais, como pontua Venâncio (1999, p. 28). Compunham ainda a administração o secretário, o visitador e dois mordomos.

A seguir, apresentaremos o organograma que representa a composição geral da Mesa dos Expostos que era válida para as Casas da roda de Portugal. No Brasil, o organograma era muito semelhante, excluindo-se em alguns casos o visitador ou o secretário.

Figura 5 - Organograma da composição geral da Mesa dos Expostos

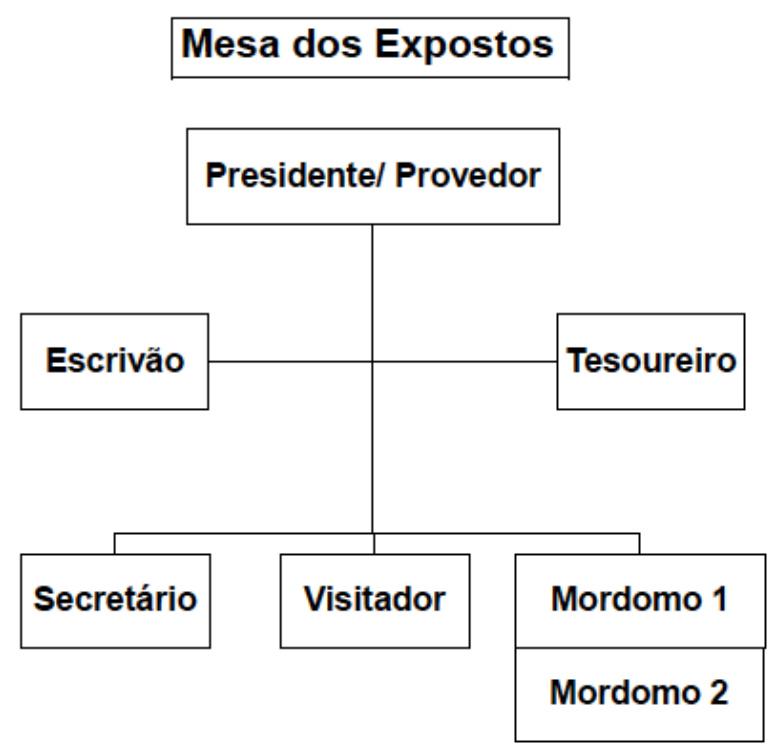


Cabia ao secretário registrar a matrícula dos enjeitados, elaborar o livro de pagamento, o de receitas e despesas e o livro de requerimentos e legados. O visitador efetuava o pagamento das amas de leite em suas próprias residências e verificava o estado da criança sob seus cuidados. Os mordomos cumpriam o papel de fiscais, tendo o poder de transferir o enjeitado a uma outra ama em caso de maus tratos.

O funcionamento interno das Casas dos Expostos era desempenhado pelas pessoas que se dedicavam diretamente ao trato das crianças que ingressavam na roda dos Expostos. O estudo de Venâncio explica as funções desempenhadas pelos funcionários da Casa dos Expostos: "a principal responsável pelo dia-a-dia da casa da roda era a ama-seca, que também recebia o título de rodeira”, cuja função era "retirar a criança da roda e entregá-la às amas-de-leite internas cujo número variava de acordo com as necessidades da época". As amas internas, a partir do recebimento do bebê, davam início aos atendimentos práticos: examinar, banhar, agasalhar, alimentar e aos procedimentos burocráticos (VENÂNCIO, 1999, p. 29).

Figura 6 - Organograma funcional geral da Casa dos Expostos

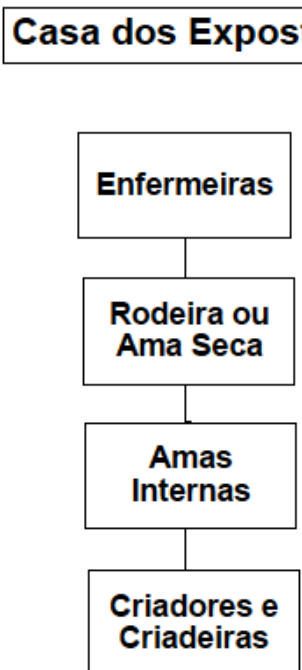

No livro de registro dos expostos, anotava-se o dia e o horário no qual a campainha soara, bem como as informações concretas como as roupas que o bebê usava, suas características físicas e se trazia consigo algum escrito ou outros objetos, como esclarecem Manoel e Colen (1999, p. 41).

Após esses procedimentos, o bebê era entregue a uma ama de leite, chamada criadeira, paga pela municipalidade, que o recebia em sua casa para amamentar o 
exposto até os três anos e criá-lo até os sete anos de idade, conforme elucida Venâncio (1999, p. 27). Após essa idade, a criança era encaminhada para aprender um ofício com vistas a ser emancipada com a maior brevidade possível.

Os expostos do sexo masculino que saíam da casa para aprender ofício deveriam receber um pagamento pelo seu trabalho. Do mesmo modo, as expostas encaminhadas para o trabalho doméstico também eram remuneradas.

O abandono infantil era uma prática bastante difundida em todo o Reino de Portugal e o ato de depositar crianças para serem criadas por caridade era legalizado.

Encontramos registros referentes ao cuidado com enjeitados e órfãos, que datam do século XIII, sob o reinado de D. Afonso III, com a fundação do Hospital dos Meninos, em Lisboa Em Santarém, por volta de 1321, foi construído um hospital para cuidar de órfãos, como aponta Moisão (2012, p. 79).

Com as Ordenações Manuelinas, no início do século XVI, foram constituídas as instituições jurídicas e administrativas encarregadas dos cuidados com os órfãos e enjeitados. A responsabilidade sobre a criação dos enjeitados, na falta de progenitores e na ausência de hospitais ou albergues dotados de bens com esta finalidade, passou a ser das Câmaras Municipais. Não havendo renda para isso, o Conselho Municipal poderia lançar impostos destinados a essa finalidade ${ }^{11}$ :

A instalação da chamada "roda dos expostos" foi estabelecida em 1783 por uma circular expedida por ordem da Rainha D. Maria I, determinando que todas as localidades do Reino possuíssem este dispositivo para depositar os enjeitados ${ }^{12}$.

As Câmaras Municipais e as Misericórdias foram as principais instituições responsáveis por sustentar a assistência às crianças abandonadas em Portugal e em suas colônias (FRANCO, 2014, p. 7).

\footnotetext{
11 (...) se alguns órfãos não forem de legítimo matrimônio forem filhos de alguns homens casados, ou de solteiros, em tal caso primeiramente serão constrangidos seus pais, que os criem; e não tendo eles por onde os criar, se criarão as custas das mães; e não tendo uns nem outros por onde os criar, sejam requeridos seus parentes que os mandem criar; e não o querendo fazer, ou sendo filhos de Religiosos, ou Frades, ou Freiras, ou de mulheres casadas, por tal que as crianças não morram por míngua de criação, os mandarão criar às custas dos bens dos Hospitais, ou Albergarias, se os houver na Cidade, Vila, ou Lugar ordenados para criação dos enjeitados; e não havendo aí tais Hospitais ou Albergarias, se criarão às custas das rendas do Conselho; e não tendo o Conselho rendas por onde se possam criar, se lançará fintas (...). Ordenações Manuelinas, Livro I, Título LXVII, p. 482. In: http://www1.ci.uc.pt/ihti/proj/manuelinas/ (acesso em 19 de junho de 2017)

12 "Em todas as Cidades, e Villas do Reino deve haver Casa de Roda, para expor os meninos, que se enjeitarem, e esta existir em o lugar mais accommodado, que possa haver, em cada huma das Terras, em que devem estabelecer-se; para que mais facilmente se possão expor as crianças sem serem observados, e conhecidos tão facilmente os seus conductores." Ordem circular da Intendência Geral da Polícia de 24 de maio de 1783. (PINTO, 1820, p. 8).
} 
Vale ressaltar que a fundação da Confraria de Nossa Senhora da Misericórdia, em Lisboa, deu ensejo à criação de dezenas de outras irmandades, que se espalharam por todo o reino, confome explica Ribeiro:

Tamanho renome ganhou, mercê de suas obras benéficas a Santa Casa de Lisboa, da qual por imitação, derivaram logo as Misericórdias de todas as villas e concelhos no continente do Reino, na Asia, na África e na América, por todas as extensas regiões do então vastíssimo império portuguez (RIBEIRO, 1902, p. 424).

Em função disso, a forma de a Misericórdia de Lisboa administrar a caridade tornou-se um modelo de assistência institucionalizada. Franco (2014, p. 7) aponta que o protagonismo da confraria "tendeu a monopolizar as novas fundações de hospitais, homogeneizando consideravelmente o sistema a partir do modelo de Lisboa".

A prática do abandono infantil ampliou-se consideravelmente, como explica Sá. Houve um aumento progressivo no abandono de crianças, até a segunda metade do século XIX:

Quer porque era relativamente fácil abandonar um recém-nascido de forma anónima (nas igrejas e outros locais muito frequentados, ou à porta de particulares) quer porque passou a existir um dispositivo - a roda -, que permitia fazê-lo de forma segura sem revelar a identidade dos abandonantes, o fenómeno cresceu exponencialmente (SÁ, 2014, p. 154).

Os enjeitados eram vistos como filhos do Estado, que tinha a responsabilidade de acolhê-los e educá-los, conforme afirma Pinto:

(...) sendo certo que a Humanidade, e a Politica pedem, que se salvem da morte criaturas desgraçadas, que apenas nasceram foram logo desamparadas pelos autores de sua existência; que se aumente a povoação, recebendo estes infelizes em o número dos cidadãos; e que se procure conseguir, que eles sejam membros úteis da Sociedade, dando-lhes uma educação, que os habilite para este fim; pois que sendo os Engeitados propriamente filhos do Estado, que faz as vezes dos Pais, que não conheceram (...) (PINTO, 1820, p.3).

A organização da assistência aos expostos, em fins do século XVIII, abrangia todo o território português e a mesma legislação, determinada pelo poder central ${ }^{13}$, aplicava-se a todas as vilas e cidades do reino. Nesse período, as despesas com as Casas das rodas e com a criação dos expostos competia aos Concelhos Municipais.

\footnotetext{
13 Ordem Circular da Intendência Geral da Polícia, 1783.
} 
Nas maiores cidades portuguesas, como Lisboa, Porto, Coimbra e Évora, a responsabilidade pelos enjeitados cabia às Santas Casas de Misericórdia. No entanto, o sistema de acolhida das crianças, bem como o envio dos enjeitados até os sete anos de idade a uma ama para aleitamento e criação, era regulado pelo Estado (Cubeiro, 2011, p. 9).

A estrutura setecentista passou a apresentar inúmeras dificuldades que interferiam no sistema de criação dos expostos, sobretudo de ordem orçamentária e de fiscalização. Dessa maneira, em 1836, uma nova lei passou a criação dos expostos à responsabilidade exclusiva dos distritos administrativos e extinguiu a competência das Misericórdias no amparo a essas crianças ${ }^{14}$.

A situação insustentável resultante do crescente número de expostos, somada às dificuldades financeiras e administrativas para a sua criação, conduziram a que, em 1852, o Código Penal Português caracterizasse como crime o abandono de crianças fora das rodas, para evitar que fossem deixadas à sua própria sorte ou em frente às casas de particulares. Leiam-se, como confirmação, os artigos 345 ao artigo 348 da figura 8 a seguir.

14 De acordo com a Sessão de 18 de Fevereiro de 1836, disponível online (http://debates.parlamento.pt/catalogo/mc/cp1/01/01/01/031/1836-02-18?sft=true\#p248), da qual se destacam os artigos 1 e 8, reproduzidos a seguir: "Art. 1. A despeza das Rodas, e creação dos Expostos será feita por Districtos Administrativos a custa de todas as Municipalidades de que cada um delles se compõe. Art. 8. ${ }^{\circ}$ Cessará a competencia que em algumas terras do Reino estava incumbida ás Santas Casas de Misericordias a respeito de Expostos, tornando-se a sua administração uniforme em toda a parte pelo modo prescripto na presente Lei, cumprindo-se fielmente as disposições do citado Alvará, que por esta não ficam derrogadas." 
Figura 7 - Página de rosto do Código Penal Português, Lisboa: Imprensa Nacional, 1855

\section{CODIGO PENAL}

APPRUVADO

POR

\section{DECRETO DE 10 DR DEZEMBRO DE 1852.}

\section{LISBOA}

IMPRENSA NACIONAL

1855. 
Figura 8 - Página da Secção 4 - Exposição e abandono dos infantes, Código Penal Português, Lisboa: Imprensa Nacional, 1855

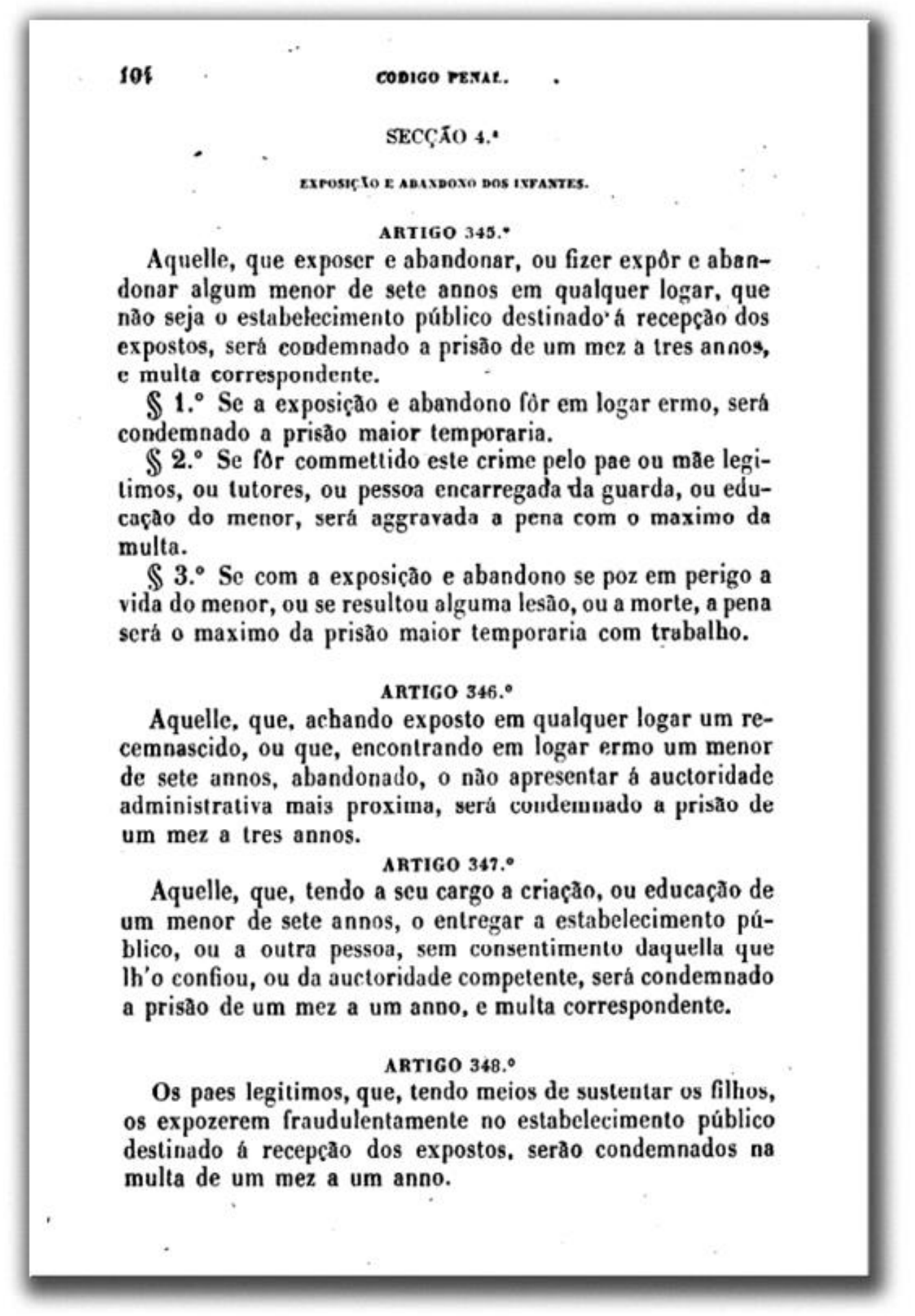

O Código Penal, aprovado em Lisboa pelo Decreto de 10 de dezembro de 1852, deixa clara a institucionalização da prática do abandono dos infantes, assim considerados até os sete anos de idade. A introdução do artigo 345 estabelece que 
seria passível de punição o abandono realizado fora dos lugares para isso determinados. Essa restrição denota que o código penal coevo não considerava crime o abandono de menores de maneira geral. Comprova-se a institucionalização e até o aceite social da prática pelos três parágrafos que seguem, em que a pena máxima em caso de morte ou lesão da criança seria prisão temporária com trabalho.

A tentativa de institucionalização do abandono que esse código parece prescrever justifica-se pela situação financeira dos pais, de acordo com o que determina o Artigo 348. Mesmo que realizada em local propício, a prática de entregar o filho à responsabilidade de terceiros geraria multa aos pais legítimos. Uma vez que havia a punição definida de multa de um mês a um ano aos pais que comprovadamente tivessem condições sociais de sustentar os filhos, enfatiza-se que o que caracterizava o abandono como algo fraudulento não é o ato em si, mas a posse de meios de sustentar essa criança. Dessa forma, embora a legislação tentasse limitar o abandono infantil, ela não penalizava o abandono anônimo nas rodas dos expostos, como explica Reis (2012, p. 162) "na prática, continua a não se penalizar o acto de abandono, mas a penalizar como se abandona".

Esse padrão institucionalizado aos poucos conduziu a polêmicas a respeito da roda dos expostos. Nesse contexto, seus críticos, sobretudo, médicos e jornalistas consideravam a existência da roda degradante e os cuidados com as crianças, ineficientes. Apontavam os altos índices de mortalidade infantil e os custos elevados para o orçamento público. Ademais, havia pressão popular contra as rodas.

Por outro lado, havia cidadãos defensores da estrutura social estabelecida tradicionalmente pelas rodas. Estes argumentavam, de acordo com Cubeiro (2011, p.10), que a instituição detinha a função essencial de salvaguardar a moralidade pública e garantir a sobrevivência de muitas crianças.

Nesse impasse que ultrapassava a questão da existência da roda, mas se situava no aspecto mais profundo da prática recorrente do abandono de crianças, uma comissão especial do governo propôs, em 1862, medidas para amenizar o problema: a substituição das rodas por abrigos de admissão vigiada (em que, em cada caso, era discutida a admissão ou não da criança) e a atribuição de subsídios de lactação para progenitores sem condições econômicas para criar seus filhos.

Essa proposta culminou com o decreto de 21 de novembro de 1867, que criou uma estrutura social mais ampla de acolhimento de crianças e extinguiu formalmente as rodas dos expostos: 
Em seu lugar, instituíram-se os hospícios de admissão restrita de crianças expostas, abandonadas (com pais conhecidos) e indigentes. Os novos hospícios seriam providos com enfermarias de maternidade e as parturientes ficavam obrigadas a criar e educar seus filhos, excepto nas impossibilidades comprovadas. Instalar-se-iam creches para os filhos de gente trabalhadora, conceder-se-iam subsídios de lactação às mães solteiras e viúvas pobres e a pais pobres, desde que fossem viúvos ou não pudessem trabalhar. As crianças abandonadas e admitidas no hospício seriam criadas por amas externas (CUBEIRO, 2011, p. 11).

Conforme o mesmo autor, este decreto não fez com que a instituição deixasse de existir imediatamente. A extinção das rodas realizou-se de maneira gradual e processual, primeiramente, nas cidades de Aveiro, Leiria, nos conselhos rurais de Lisboa, Porto, Penafiel, Ponte de Lima e Torres Novas e, tempos depois, nas cidades de Lisboa, Coimbra, Viseu, Bragança, Évora, Beja e demais localidades em Portugal.

Cabe ressaltar que o problema do abandono ultrapassava a questão da existência das rodas. Sendo assim, a extinção das rodas não impediu que essa espécie de tradição social de abandonar crianças para serem criadas pelo Estado continuasse, conforme descreve Paulino:

Efectivamente, o decreto estabelece uma ruptura face ao antigo modelo assistencial de acolhimento aos expostos. Porém, pode-se questionar qual o alcance desta mudança, quando o percurso das crianças continuou a ser 0 mesmo - os pais eram identificados, mas os abandonados continuavam (...) sendo (...) enviados para uma ama no meio rural. (PAULINO, 2014, p. 201202).

Em 1888, o Regulamento para o Serviço dos Expostos e Menores Desvalidos ou Abandonados ${ }^{15}$, seguida no Brasil e em Portugal, refere que "estão a cargo das câmaras municipais e das juntas gerais até a idade de sete anos os expostos, as crianças abandonadas e as crianças desvalidas", sendo os primeiros "as crianças nascidas de pais incógnitos que as desampararam". Por um lado, essa nova legislação amplia o escopo de crianças amparadas pelo Estado, mas, por outro lado, continua protegendo o abandono de crianças por pais desconhecidos. Nesse sentido, pode-se afirmar que "certo é que pelo menos até à primeira década do século XX são ainda encontrados registros e relatos sobre expostos", embora atualmente possa parecer "difícil perceber esta prática como uma ação recorrente, natural e aceitável" (LEANDRO, 2011, p. 140).

1505 de janeiro de 1888. Collecção Official da Legislação Portugueza, Anno de 1888, Imprensa Nacional, Lisboa, 1889. 
Após a sucinta contextualização geral das rodas, apresentam-se pormenores do histórico e organização de funcionamento de cada uma das rodas de onde originaram os escritos do corpus.

\section{A roda de Lisboa (Santa Casa de Misericórdia de Lisboa - SCML)}

A roda de Lisboa, cuja origem remonta ao Hospital Real de Todos os Santos, tinha a responsabilidade de receber enjeitados. As crianças ficavam no chamado "Hospital dos expostos", onde também se abrigavam doentes, peregrinos, idosos e mendigos, que lá permaneciam para fins de tratamento e hospedagem.

Em 1564, a administração do Hospital Real passou à Misericórdia, conforme Manoel e Colen (1999, p. 40.). Sabe-se que "em 1616 entraram 200 enjeitados no criandário estabelecido na parte do grande edifício que dava para a Rua da Betesga; a roda era num Beco à esquerda nesta mesma Rua, onde hoje começa a Rua dos Fanqueiros" (RIBEIRO, 1902, p. 394). Em 1657, foi instituída a Mesa dos Enjeitados ou dos Santos Inocentes. No ano seguinte, por meio de um decreto, a Câmara Municipal de Lisboa foi incumbida do pagamento de uma verba anual para os expostos.

As dificuldades financeiras para o acolhimento e a criação dos expostos sempre estiveram presentes na história dessa Santa Casa de Misericórdia. "Encontrou sempre a Misericórdia de Lisboa proteção decidida, não só nos soberanos, como também no Município da Capital, que repetidas vezes lhe acudiu nos seus apuros, concedendoIhe quantiosas esmolas" (RIBEIRO, 1902, p. 115). Testadores e doadores contribuíam com quantias valiosas, mas a escassez de recursos era constante tanto por consequência dos avultados encargos como pela má administração de seus bens.

Em detrimento da estrutura já mantida com dificuldades, no ano de 1755, o terrível terremoto de Lisboa, seguido de um incêndio de grandes proporções, atingiu os edifícios da Misericórdia e o Hospital de Todos os Santos. A roda dos expostos, os equipamentos, bem como os arquivos e documentos da Santa Casa que lá se encontravam foram destruídos. Dessa maneira, as atividades da Misericórdia passaram a ser exercidas em vários edifícios alugados ou emprestados, até que a Misericórdia recebeu por Carta Régia de 6 de fevereiro de 1768, em doação, a Igreja e a casa de S. Roque, conforme Antunes (2014, p. 53). 
Como vinham cidadãos de várias partes do Reino, sobretudo das proximidades da capital, depositar crianças na roda de Lisboa, sobrecarregavam-se as amas de serviço e crescentes despesas eram atribuídas a essa Santa Casa. Como prova dessa sobrecarga, Ribeiro (1902, p. 401) aponta um aumento de subvenção da Câmara Municipal para 2:000\$000 réis no ano de 1775. Mesmo com tal subvenção, a Mesa da Misericórdia de Lisboa pediu providências ao Governo, para que as Câmaras de outras localidades contribuíssem com as despesas dos expostos.

O afluxo de expostos para a roda da Santa Casa de Lisboa avolumava-se rapidamente. Em 1791, a Mesa da Santa Casa de Misericórdia publicou um edital determinando a instalação de outras rodas nos subúrbios de Lisboa:

A mesa da Santa Casa da Misericordia e Hospitaes Reais dos Enfermos e Expostos d'esta Côrte, querendo facilitar todo o commodo para a exposição das creanças que nascem ao desamparo, tem determinado estabelecer pelos subúrbios de Lisboa vários logares de roda aonde com menor risco possam ser entregues as ditas creanças para d'alli imediatamente se conduzirem á Real Casa dos Expostos d'esta Cidade pelas pessoas que para isso houver de nomear (RIBEIRO,1902, p. 402).

Como se explicita, diversas providências foram tomadas para auxiliar os expostos da Misericórdia. Dentre elas, destaca-se que, em 1801, foi criada a "Real Ordem das Damas Nobres de Santa Isabel" (ANTUNES, 2014, p. 57), cujos estatutos foram aprovados em 1804. Esta instituição era composta pela família Real e por mais 26 damas nobres, e seu principal objetivo era apoiar os expostos, e, em alguns casos, subvencionar os custos com sua criação

Em 11 de setembro de 1802, foi publicado Alvará relativo aos privilégios concedidos aos maridos e filhos das amas que criavam as crianças enjeitadas. A situação tornou-se insustentável e, em 1804, a Mesa expôs o risco de falência e solicitou uma ajuda à Coroa com urgência, pedindo também a continuidade de duas loterias anuais para seu equilíbrio financeiro, como elucida Antunes (2014, p. 57).

Nas décadas seguintes, a assistência prestada pela Misericórdia aos expostos tornou-se cada vez mais precária em Lisboa. Em 1834, um relatório do Ministro dos Negócios do Reino expôs o estado "deplorável" em que se encontravam as instalações hospitalares e as condições de saúde das crianças, demonstrando também índices de mortalidade infantil e os atrasos nos pagamentos das amas. A Mesa da Misericórdia foi dissolvida e uma Comissão Administrativa foi instaurada para reger o Hospital dos Expostos, ainda conforme Antunes (2014, p. 59-60). 
A partir de 1836, as Misericórdias deixaram de administrar a assistência aos expostos em Portugal. A única roda dos expostos que continuou sendo administrada pela Santa Casa de Misericórdia foi a roda de Lisboa. Dessa maneira, o antigo compromisso da Misericórdia foi reformado por decreto, em 26 de novembro de 1851. Nesse novo contexto, a Mesa Administrativa e o Provedor da Santa Casa passaram a ser nomeados pelo Rei.

A Junta Geral do Distrito de Lisboa, em 1863, com base no relatório de uma comissão designada para estudar o tema das rodas, decretou que se regulamentasse o serviço dos expostos. Nessa peça jurídica, Antunes $(2014$, p. 62) afirma que já se antecipava a extinção das rodas e sua substituição por um sistema de admissão da criança perante a identificação dos pais ou da pessoa que a abandonasse, e também a criação de subsídios de criação às mães.

A grave situação dos expostos em meados do século XIX pode ser medida pelos dados coletados por Ribeiro no ano de 1863, entraram nas rodas de Portugal 16.294 crianças, e eram sustentadas pelo Estado mais 36.753 crianças, o que totalizava um exposto para cada 109 habitantes, sendo um exposto para cada oito nascimentos. Estatísticas da época descrevem a elevada mortalidade infantil: entre os anos de 1863 e de 1869, entraram na roda de Lisboa 87 cadáveres de crianças, provavelmente provenientes de crimes que ficaram impunes. (RIBEIRO, 1902, p. 149151):

Tantas questões sociais por certo influenciaram na extinção já citada do mecanismo da roda em todo o país no ano de 1867. Retoma-se que a real extinção da roda de Lisboa foi postergada, somente em 1 de dezembro de 1870, o Provedor da Santa Casa de Misericórdia de Lisboa resolveu encerrar o acolhimento de crianças por meio da roda. Os expostos passaram a ser deixados diretamente no interior da Casa da roda dos expostos, e apenas durante o período diurno. Um funcionário era encarregado de receber os menores abandonados e registrar informações como o nome dos pais ou da pessoa condutora do menor, bem como as causas da exposição. Nesse contexto, eram recebidas crianças: a) Abandonadas na rua, sobre os quais não tinha sido possível descobrir a respectiva filiação; b) Filhas de mães falecidas no Hospital e que não possuíam mais familiares; c) Filhas de condenados pela justiça; d) Filhas de mães solteiras ou em decadência moral, como lista Antunes (2014, p. 63). 
Como o sistema de entrega dos menores passou a exigir o registro da identificação dos pais, a produção documental alterou-se. O número de sinais diminuiu e outros documentos passaram a ser produzidos: os formulários.

O gráfico abaixo mostra o fluxo de entrada de crianças na Santa Casa de Lisboa antes e após a extinção da roda dos expostos em Lisboa pelo Provedor (1870).

Gráfico 1 - Crianças abandonadas na SCML (1850-1903)

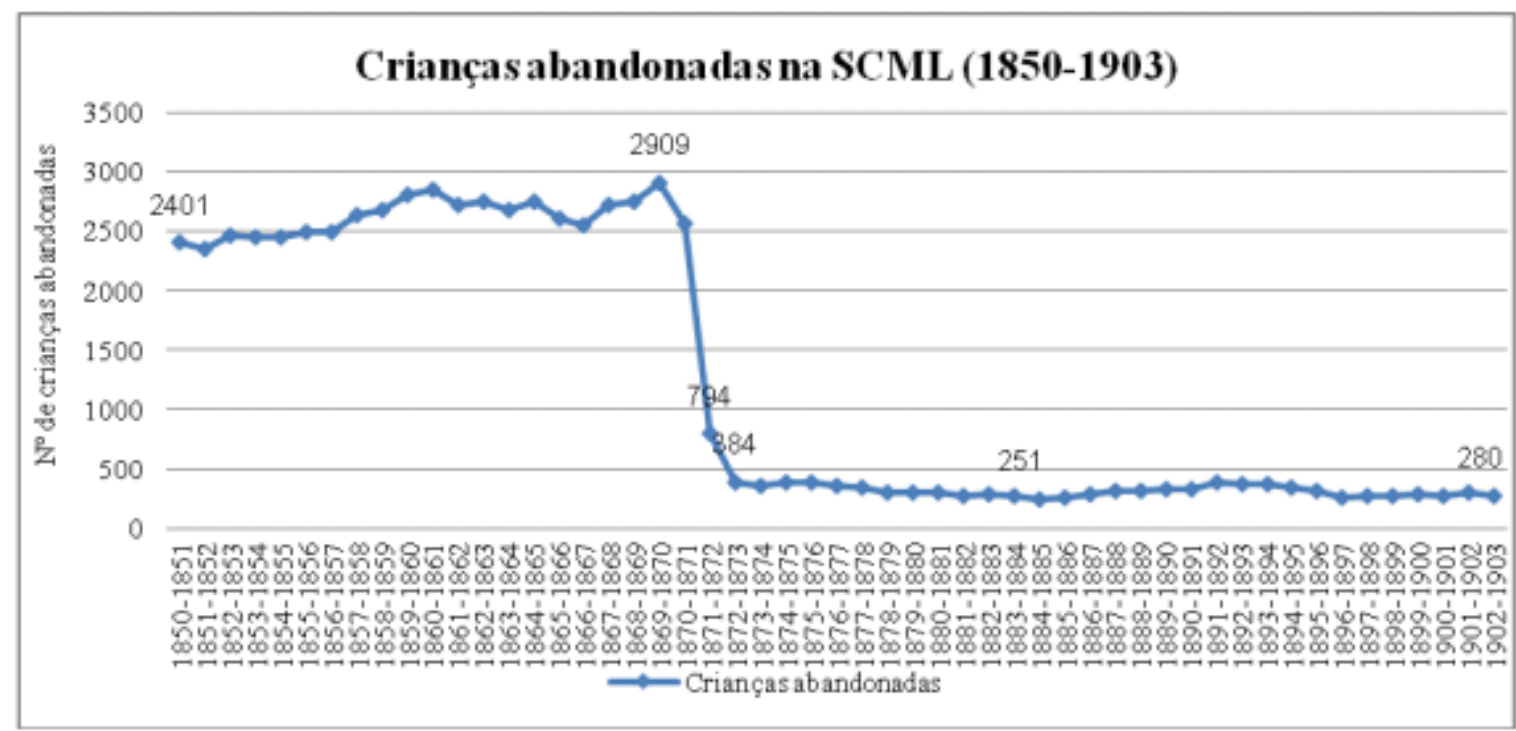

Fonte: Paulino (2014, p. 190)

É possível distinguir duas fases bem demarcadas na exposição de crianças na Santa Casa de Misericórdia de Lisboa, anterior (1850-1870) e posterior (1871-1903) à extinção das roda e do abandono anônimo. Na primeira fase, embora os números oscilassem, podemos notar a exposição crescente. Não obstante os debates públicos que antecederam a extinção da roda e o decreto de 1867 (que extinguiu a roda em todo o país), a entrada de expostos atingiu seu pico máximo em 1870.

Na segunda fase, após o fechamento da roda na Misericórdia de Lisboa, a entrada de crianças passa seu último período de maior diminuição entre 1871 e 1873, estabilizando-se a seguir num patamar bem abaixo daquele que se encontrava na primeira fase.

Após esse breve histórico a respeito da roda de Lisboa, segue-se o estudo das rodas dos expostos brasileiras, de cujos arquivos coletamos escritos para compor o corpus deste trabalho. 


\section{As Rodas dos Expostos no Brasil}

Por sua vez, as instituições brasileiras ofereceram abrigo e proteção aos expostos, seguindo os mesmos modelos das instituições portuguesas, mesmo após a independência de Portugal.

As cidades brasileiras, no entanto, não estabeleceram a regra de contratar funcionários para recolher as crianças abandonadas nas ruas, nas portas das igrejas e diante de domicílios. Em fins do século XVII, cada Câmara Municipal estabelecia suas próprias regras de auxílio aos enjeitados. Conforme Venâncio (1999, p. 27), "a ausência de controle permitia que os vereadores promovessem clientelas do meio urbano, contratando famílias criadeiras entre seus dependentes". Nessa época, a demanda por recursos destinados aos enjeitados era cada vez maior, impactando nos cofres das Câmaras. O avultamento desses gastos das Câmaras com os enjeitados fez com que os governadores transferissem a responsabilidade para as Santas Casas, instalando as chamadas "Casas das rodas" ou "Casa dos Expostos"16.

A transferência da responsabilidade das Câmaras Municipais para as Santas Casas de Misericórdia seguiu uma prática já adotada em Portugal, mas necessitou de negociações e ajustes para ser implementada no Brasil. De acordo com Venâncio (1999, p. 28), as Santas Casas relutaram em estabelecer o dispendioso auxílio aos abandonados. Sendo assim, a instalação da Casa da roda ou Casa dos expostos acontecia quando surgiam benfeitores ou quando a Câmara acertava contratos com a Misericórdia, transferindo-Ihe a administração dos expostos mediante o pagamento de soma anual.

A instalação das rodas dos expostos nas Santas Casas deu-se gradualmente durante os séculos XVIII e XIX, como podemos observar nos dados do quadro abaixo.

\footnotetext{
${ }^{16}$ Durante os anos 1710 e 1720 foram inúmeras as consultas e negociações entre as Câmaras e as Santas Casas cariocas e soteropolitanas. Entre 1726 e 1738, graças à doação de verdadeiras fortunas por parte de benfeitores e da regularização de contribuições por parte do poder municipal, a transferência do encargo teve início. O modelo administrativo pelo qual o auxílio da Santa Casa deveria se pautar apresentava várias diferenças em relação ao proporcionado pelo poder camarário, a começar pela instalação da Roda dos Expostos, que implicava subordinar o abandono a uma visível ruptura dos laços familiares. (VENÂNCIO, 1999, p. 28).
} 
Quadro 1 - Datas de instalação das rodas dos expostos no Brasil

\begin{tabular}{|c|c|}
\hline Capitania & $\begin{array}{c}\text { Roda dos Expostos por } \\
\text { ano }\end{array}$ \\
\hline Bahia (Salvador) & 1726 \\
\hline Rio de Janeiro & 1738 \\
\hline Pernambuco (Recife) & 1789 \\
\hline Rio de Janeiro (Campos) & 1796 \\
\hline São Paulo (São Paulo) & 1825 \\
\hline Santa Catarina (Desterro) & 1828 \\
\hline Maranhão (São Luís) & 1829 \\
\hline Minas Gerais (São João Del Rei) & 1832 \\
\hline Mato Grosso (Cuiabá) & 1833 \\
\hline Rio Grande do Sul (Porto Alegre) & 1837 \\
\hline Bahia (Cachoeira) & 1840 \\
\hline Paraíba (João Pessoa) & 1841 \\
\hline Rio Grande do Sul (Pelotas) & 1849 \\
\hline
\end{tabular}

Fonte: Ferreira, L. (2011, p. 38).

De modo geral, no Brasil, as Casas da roda serviam para acolher os expostos e enviá-los para serem amamentados por amas e criados por famílias, haja vista que essas casas de acolhimento não tinham estrutura material própria para mantê-los permanentemente ${ }^{17}$.

Diferente da complexa estrutura administrativa das Casas da roda na metrópole, o funcionamento efetivo das Casas na colônia era precário e não dispunha de mecanismos de fiscalização.

Tal situação era motivo de preocupação entre os administradores das casas da roda coloniais que não dispunham de recursos para criar a estrutura administrativa prevista. Talvez por isso, as modificações nas leis e nos regimentos, ocorridas em Portugal durante a segunda metade do século XVIII, tenham sido ignoradas na colônia (VENÂNCIO, 1999, p. 29).

Na maior parte dos casos, as crianças viviam sob os cuidados das amas até os sete anos de idade. Posteriormente, eram transferidas para educandários, internatos e asilos, também de responsabilidade das Santas Casas. Nesses locais sempre havia a preocupação em alimentar, dar educação e instrução e um ofício aos expostos.

Há registros de que as crianças da roda, após aprenderem um ofício, eram encaminhadas para fazendas ou famílias para prestarem serviços. O pagamento que

17 Conforme o Venâncio (1999, p. 52), as casas da Roda não eram asilos. Simplesmente acolhiam crianças e as enviavam a outras famílias, a quem se oferecia ajuda financeira como retribuição. Ressalta-se que as instituições soteropolitana e carioca funcionaram no próprio hospital da Santa Casa de Misericórdia. 
recebiam ficava sob a guarda da Santa Casa, para constituição do dote da criança, a ser usado ao se casar ou ao adquirir sua maioridade e independência e poder retirar a quantia acumulada. Contudo, há casos entre os chamados "filhos da roda"18, de indivíduos que nunca saíram da tutela da Santa Casa, tendo vivido toda a vida e morrido nos muros da instituição.

A transferência da Corte Portuguesa para o Rio de Janeiro, em 1808, criou novas demandas para as Santas Casas, em razão do crescimento populacional e, consequente, do aumento do número de expostos.

Em 1815, o Príncipe Regente determinou a criação de novos impostos para fazer frente à "sustentação e criação destes inocentes", atendendo a uma solicitação do Provedor da Misericórdia do Rio de Janeiro de conceder "a mesma graça outorgada à Misericórdia de Lisboa em 1775", conforme consta na Carta Régia de dezembro de 1815 parcialmente transcrita a seguir:

Requerendo-me o Provedor da Misericordia desta Cidade a mesma graça
outorgada a de Lisboa por Carta Regia de 31 de Janeiro de 1775 em beneficio
dos Expostos, cujo numero tem consideravelmente crescido, e crescerá cada
vez mais pelo augmento em que vai a população, não chegando por isso os
seus tenues rendimentos para satisfazer a tão importantes despezas;
(...)
"querendo eu prover a tão urgente necessidade com os paternaes desvelos
que sempre me mereceu a criação dos innocentes Expostos; hei por bem e
ordeno que em beneficio delles se cobre na Casa da Supplicação do Brazil
400 réis sobre cada uma das petições de aggravo que a ella subirem, a terça
parte de accrescentamento das assignaturas que se costumam vencer na
Mesa de Aggravos, outra terça parte mais na braçagem dos ministros
Estravagantes, e outra igual parte na braçagem dos sete Juizes relatores da
mesma Casa (...) para ser logo entregue no fim de cada mez, na Thesouraria
da Casa da Misericorida a administração do sobredito Hospital dos Expostos,
afim de applicar a sustenção e criação destes innocentes. (Carta Régia, 14
de dezembro de 1815.)

Após a Independência, no período Imperial, os expostos maiores de sete anos encontraram ofício, não apenas em instituições administradas pela Igreja, mas também em organizações patrocinadas pelo Estado, conforme Ferreira (2011, p. 14) "novas instituições surgiram para abrigar, educar e ensinar algum tipo de ofício às crianças carentes maiores de sete anos de idade." Tais instituições foram as seguintes, de acordo com o mesmo autor: os Colégios Pios, Escolas de Aprendiz de Arsenal de Guerra e de Marinheiros, Recolhimento e Asilos para órfãs e Colônias Agrícolas e Industriais.

\footnotetext{
${ }^{18}$ Expressão que designa pessoa que foi acolhida pela Roda dos Expostos.
} 
Do mesmo modo que, em Portugal, com o passar do tempo, as rodas dos expostos foram se tornando mecanismos discutíveis do ponto de vista social e moral, principalmente, pelos números cada vez maiores de expostos recebidos, o que sugeria um estímulo à irresponsabilidade das famílias para com seus filhos, causando polêmicas na imprensa e nos meios mais cultivados (CUBEIRO, 2011, p.10-11).

Contudo, o fechamento das rodas dos expostos no Brasil ocorreu muito mais lentamente do que na metrópole, tendo adentrado o período republicano. Não houve, no período, qualquer planejamento ou política de compensações, como subsídios de lactação ou auxílio às famílias, como ocorreu em Portugal, no período posterior à extinção das rodas:

Diferentemente de Portugal ou de outros reinos europeus, o fechamento da roda não foi acompanhado por políticas assistenciais de socorro às lactantes, auxílio a famílias pobres ou instalação de creches populares. Tal evolução, na primeira república brasileira, abriu caminho para a progressiva dependência da assistência à infância em relação à filantropia privada (VENÂNCIO, 2008, p. 15).

Nesse sentido, diversas instâncias sociais podem ser citadas como relacionadas ao abandono de crianças. Conforme a monarquia chegava ao fim, aumentava a pressão abolicionista. No primeiro reinado, em 1871, a lei do Ventre Livre tornava livres os filhos dos escravos, sem estabelecer políticas sociais para as crianças nascidas nesta condição.

Com o advento da República, em 1889, o contexto social e político do abandono de menores alterou-se substancialmente. O fim do regime escravista, o aumento da população urbana pobre e a separação Igreja-Estado aumentaram o número de crianças em situação de miséria. Com isso, o modelo de acolhimento dos enjeitados passou por uma profunda transformação. A questão da infância desvalida distanciouse da caridade cristã e se aproximou da área jurídica e da medicina (PUBLIO, 2011, p. 38),

Este movimento fez com que, em 1891, período da Primeira República, um decreto regularizasse o trabalho infantil nas fábricas do Rio de Janeiro, estabelecendo a idade mínima de 12 anos para admissão de menores. A seguir, em 1916, o Código Civil, estabeleceu que o sustento, a guarda e a educação dos filhos são deveres de ambos os cônjuges. Até então não havia legislação específica pertinente à situação das crianças no país, que tratasse de seus direitos, conforme Silva (2016). No ano seguinte, em 1927, foi publicado o Decreto 17.943-A, chamado de "Código de 
Menores de Mello Matos", que regulou a situação legal de menores no Brasil. Desse código destaca-se o capítulo III, que trata especificamente da questão dos expostos:

\section{CAPITULO III}

\section{DOS INFANTES EXPOSTOS}

Art. 14. São considerados expostos os infantes até sete annos de idade, encontrados em estado de abandono, onde quer que seja.

Art. 15. A admissão dos expostos á assistencia se fará por consignação directa, excluido o systema das rodas.

Art. 16. As instituições destinadas a recolher e crear expostos terão um registro secreto, organizado de modo a respeitar e garantir o incognito, em que se apresentem e desejem manter os portadores de creanças a serem asyladas.

Art. 17. Os recolhimentos de expostos, salvo nos casos previstos pelo artigo seguinte, não podem receber creança sem a exhibição do registro civil de nascimento e a declaração de todas as circumstancias que poderão servir para identifical-a; e deverão fazer a descripção dos signaes particulares e dos objectos encontrados no infante ou junto deste.

Art. 18. Si é a mãe que apresenta o infante, ella não é adstricta a se dar a conhecer, nem a assignar o processo de entrega. Si, porém, ella espontaneamente fizer declaração do seu estado civil, que qualquer outra que esclareça a situação da creança, taes declarações serão recebidas e registradas pelo funccionario do recolhimento.

$\S 1^{\circ}$ Ella poderá tambem fazer declarações perante um notario da sua confiança, em acto separado, que é prohibido communicar ou publicar sob qualquer forma, salvo autorização escripta da autoridade competente; e entregar ao respectivo funccionario do recolhimento esse documento encerrado e lacrado, para ser aberto na época e nas circumstancias que ella determinar, e que ficarão constando do registro da creança.

$\S 2^{\circ} \mathrm{Si}$ é uma outra pessoa que apresenta o infante. O funccionario do recolhimento procurará mostrar-lhe os inconvenientes do abandono, sem, todavia,. fazer pressão, sob pena de demissão. Si o portador da creança insistir em a deixar, o funccionario pedirá o registro civil de nascimento, ou informações do cartorio e da data em que foi feito o registro. Si o portador declarar que não póde, ou não quer, fornecer indicação alguma, essa recusa ficará registrada, mas a creança será recolhida.

Art. 19. A violação do segredo de taes actos é punida com multa de $50 \$$ a $500 \$$, além das penas do art. 192, do Codigo Penal.

Art. 20. Si o infante fôr abandonado no recolhimento, em vez de ser ahi devidamente apresentado, o funccionario respectivo o levará a registro no competente officio, preenchendo as exigencias legaes; sob as penas do art. 388 do Codigo Penal.

Art. 21. Quem encontrar infante exposto, deve apresental-o, ou dar aviso do seu achado, á autoridade policial no Districto Federal ou, nos Estados, á autoridade publica mais proxima do local onde estiver o infante.

Art. 22. A autoridade, a quem fôr apresentado um infante exposto, deve mandar inscrevel-o no registro civil de nascimento dentro do prazo e segundo as formalidades regulamentares, declarando-se no registro o dia, mez e anno, o logar em que foi exposto, e a idade apparente; sob as penas do art. 388 do Codigo Penal, e os mais de direito.

$\S 1^{\circ} \mathrm{O}$ envoltorio, roupas e quaesquer outros objectos e signaes que trouxer a creança, e que possam a todo tempo fazel-a reconhecer, serão numerados, alistados e fechados em caixa lacrada e sellada, com o seguinte rotulo: "pertencente ao exposto tal........ assento de fl..... do livro........."; e remettidos com uma duplicata ao juiz de menores, onde o houver, ou ao juiz de orphãos, para serem recolhidos a logar de segurança. 
$\S 2^{\circ}$ Recebida a duplicata com o competente conhecimento do deposito, que será archivada, far-se-hão á margem do assentamento as notas convenientes.

Art. 23. Os expostos que não forem recolhidos a estabelecimentos a esse fim destinados, ficarão sob a tutela das pessoas que voluntaria 0 gratuitamente se encarreguem da sua creação, ou terão tutores nomeados pela juiz.

Art. 24. Quem tiver em consignação um infante, não póde confial-o a outrem, sem autorização da autoridade publica ou do quem de direito; salvo si não fôr legalmente obrigado, ou não se tiver obrigado, a prover gratuitamente á sua manutenção.

Art. 25. Incorrerá em pena de prisão cellular por um a seis mezes e multa de 20\$ a 200\$000:

I, quem entregar a qualquer pessoa ou a estabelecimento publico ou particular, sem o consentimento da autoridade ou da pessoa de quem houver recebido, menor abaixo da idade de sete annos.

II, quem, encontrando recem nascido ou menor de sete annos abandonado, não o apresentar ou não der aviso do seu achado, á autoridade publica.

Decreto 17.943-A, Capítulo III; Codigo de Menores de Mello Matos, 1927

(grifos nossos)

Destaca-se o fato de o Código de Mello Matos ter ampliado os poderes dos Juízes e dos Comissários em relação às crianças, caracterizando-as como "menores", fortalecendo o intervencionismo oficial no âmbito da família.

Como resultado das negociações para erradicar o Sistema da roda e a Casa dos Expostos, garantiu-se também o segredo de justiça, reservando-se às entidades de acolhimento de menores e aos cartórios de registro de pessoas naturais o sigilo em relação aos genitores que quisessem abandonar os seus filhos, garantindo-se em particular o sigilo da mãe quanto ao seu estado civil e as condições em que foi gerada a criança (SILVA, 2001, p.5).

Apesar da vigência do Código de Menores e das denúncias de procedimentos inadequados referentes ao tratamento dado aos expostos, a extinção das rodas não foi imediata. Grande parte da sociedade da época era contra a extinção das rodas, pois estas eram vistas como a única forma possível de esperança de vida aos bebês que tinham como destino o sofrimento e/ou a morte, preservando assim os costumes, a dignidade das famílias que abandonavam e a ordem social, de acordo com Públio (2011, p. 41).

Em 1940, período do Estado Novo, compromissado com questões sociais ${ }^{19}$, o abandono de menores de idade passou a ser considerado crime no Brasil. O DecretoLei $n^{0} 2.848 / 40$, o Código Penal, afirma em seus artigos 134 e 243:

19 Os documentos estudados nesta tese estão inseridos no contexto histórico que parte do Brasil Colonial, percorre o Primeiro Reinado (1822-1831), a Regência (1831-1840), Segundo Reinado (18401889), Primeira República (1889-1930), Estado Getulhista (1930-1945) e finaliza no início do período 


\section{Exposição ou abandono de recém-nascido}

Art. 134. Expor ou abandonar recém-nascido, para ocultar desonra própria: Pena - detenção, de seis meses a dois anos.

$\S 1^{\circ}$ Se do fato resulta lesão corporal de natureza grave:

Pena - detenção, de um a três anos.

$\S 2^{\circ}$ Se resulta a morte:

Pena - detenção, de dois a seis anos.

(...)

Sonegação de estado de filiação

Art. 243. Deixar em asilo de expostos ou outra instituição de assistência filho próprio ou alheio, ocultando-lhe a filiação ou atribuindo-Ihe outra, com o fim de prejudicar direito inerente ao estado civil:

Pena - reclusão, de um a cinco anos, e multa de um conto a oito contos de réis.

Decreto-Lei nº 2.848/40, o Código Penal, 1940.

As crianças, no entanto, continuaram a ser deixadas em instituições administradas pelas Santas Casas, como podemos testemunhar pelo livro de registros ${ }^{20}$ da Santa Casa de Misericórdia da Bahia, reproduzido abaixo. A carta ${ }^{21}$ está apensa ao registro de entrada da criança, datado de dezembro de $1958^{22}$.

Democrático (1945-1964). Periodização com base na obra História do Brasil. FAUSTO, 1995, p. 35382.

20 Transcrição do livro de registros: "1958| Dezembro| Pelas 11,30 da manhã foi regis-|trado no Escritório de Admissaõ dol Internato de Nossa Senhora da Misericórdia, uma| creança do sexo masculino de cor branca,| aparentando 1 ano de idade. Cai aban-|donado no Gabinete Medico da Ligal Contra Mortalidade Infantil. E| uma creança paralitica e anormal.| Trouxe os seguintes objetos.|1 Vestidinho branco|1 Fralda| Declaração|Nome da creança - Jorge Gomes de Jesus|Nome da genitora - Nilce Gomes de Jesus|Lugar do nascimento - Maternidade|Nita Costa|Data do nascimento - 20 de Julho de|1957.|Já está batizado|[[f. 2]] Jorge Gomes de Jesus| Observações| Jorge Gomes| De Jesus| faleceu no dia $1^{\circ} \mid$ de março de 1962|às 4 horas e 30 mi-|nutos.

${ }^{21}$ Transcrição da carta: Querida irmaẽs de caridade| apelo para esta criança vôces tomarem| conta, porque eu me acho em condiçoẽs| de não poder, criar, pois sou uma mulher| pobre, vivo de emprego de cozinha em| casas de famílias, ultimamente não tenho| encontrado mais emprego, quando digo que| tenho um filho. Logo me dizem que fosse| para mim só eu lhe arranjava, mais com| filho não. Eu que não tenho coração del matar meu filho; Apelo para uma casa| de Caridade que eu possa trabalhal sabendo que meu filho estas vivo; todo| o tempo que Deus me ajudar, que eu passa| te-lo com migo, eu irei buscar-lo não| der meu filho a niguem, eu tenho fé| em Deus, que um dia, eu é de ter êle| com migo, eu faço isto de me disarpar-|tar do meu filho. Já é batizao o nome| dele é Jorge Gomes de Jesus nacido em 20| de Julho de 1954. Os médicos dizem que êçe é| é doente retardado, êle só dorme diburço| senão não dorme. mais uma vez eu peço| não der meu filho a ninguém, que mais tarde| [De]us me ajudando eu vou procurar| [linha recortada]

${ }^{22}$ Mais uma vez alertamos que essa criança não deu entrada na instituição por meio Roda, caso contrário a carta reproduzida acima faria parte de nosso corpus. Reforçamos ainda que todos os escritos de Salvador que nos foram fornecidos no arquivo da roda de Salvador - e informados como os únicos existentes - fazem parte do corpus. 
Figura 9 - Registro de entrada do exposto Jorge Gomes de Jesus, com identificação da mãe, acompanhado de escrito, 1958



O exposto, citado no documento acima reproduzido, tinha paralisia e era "anormal". Faleceu 4 anos após sua chegada, anteriormente, portanto, a sua genitora conseguir buscá-lo conforme desejo expresso no escrito que acompanhou a criança.

Um novo Código de Menores passou a ser elaborado e finalmente entrou em vigor em 1979. A transição entre os dois Códigos efetuou-se com a criação da Fundação Nacional do Bem-Estar do Menor (FUNABEM), em 1964. A organização, concebida com autonomia financeira e administrativa, destinava-se a atender ao mesmo tempo menores carentes, abandonados e infratores, prevendo sua internação em estabelecimentos apropriados.

Com base nesta entidade, formulou-se uma Política Nacional do Bem-Estar do Menor, inspirada no que passou a reger todas as entidades estaduais e municipais de atendimento à criança e ao adolescente.

O novo Código passou a unificar a terminologia utilizada anteriormente, designando os menores como "crianças em situação irregular": 
[O juiz de menores do Rio de Janeiro] Alyrio Cavallieri foi quem propôs e fez aprovar no Código de Menores de 79 a substituiçãoo das diferentes terminologias pelas quais se designava a criança, exposto, abandonado, delinquente, transviado, infrator, vadio, libertino, etc, reunindo-os todos sob a mesma condição de "situação irregular". (SILVA, 2001, p. 5).

A redemocratização do país e o reordenamento jurídico que resultou na Constituição de 1988 culminaram na criação do Estatuto da Criança e do Adolescente (ECA), em 1990. Conforme a lei,

Criança, até 12 anos, e adolescente, até 18, são então definidos como "pessoa em fase de desenvolvimento", eliminou-se a rotulação de "menor", "infrator", "carente", abandonado", etc, classificando-os todos como crianças e adolescentes em situação de risco (SILVA, 2001, p.6).

A seguir, apresentamos uma quadro-resumo da legislação brasileira relativa ao registro civil e proteção de crianças e adolescentes em situação de risco.

Antes das leis abaixo listadas, a sociedade brasileira era regida pelas Ordenações do Reino de Portugal. 

Quadro 2 - Legislação brasileira relativa à proteção de menores

\begin{tabular}{|c|c|c|c|}
\hline \multicolumn{4}{|c|}{ Legislação brasileira relativa ao registro civil e à proteção de menores } \\
\hline Ano & Legislação & Artigo e Descrição & Contextualização/Comentários \\
\hline 1852 & Decreto 798 & $\begin{array}{l}\text { Art. } 6^{\circ} \text { O registro do nascimento será feito á vista da participação da } \\
\text { pessoa que por este Regulamento he obrigada a faze-la, e no prazo de } \\
\text { dez dias depois de dado á luz o recem-nascido. } \\
\text { Art. } 7^{\circ} \text { São obrigados a fazer a participação do nascimento: } \\
1^{\circ} \text { O pae, sendo filho legitimo o recem-nascido; e na sua falta a mãi } \\
\text { ou pessoa por elles autorisada. } \\
2^{\circ} \text { A mãi do recem-nascido, sendo elle filho illegitimo, ou o pae que o } \\
\text { reconhecer, ou pessoa por elles autorisada. } \\
3^{\circ} \text { Os funccionarios das casas de Caridade ou Hospicios, que tiverem } \\
\text { essa incumbencia, se for exposto o recem-nascido; ou a pessoa, em cuja } \\
\text { casa for deixado, ou que o tiver achado em abandono, ou que for para } \\
\text { isso autorisada. } \\
4^{\circ} \text { O Sr. do recem-nascido escravo, ou o administrador de casa, } \\
\text { fazenda, ou qualquer estabelecimento rural, ou pessoa por elles } \\
\text { autorisada. } \\
\text { Art. } 8^{\circ} \text { O Escrivão lavrará no livro competente hum termo, em que declare } \\
\text { o dia, mez e anno, e lugar em que he escripto } \\
1^{\circ} \text { Se o recem-nascido for algum exposto, far-se-ha declaração da } \\
\text { idade provavel, do sexo, do nome que tiver, ou que se houver de lhe } \\
\text { dar, dos signaes que trouxer, e de quaesquer circumstancias de } \\
\text { tempo e lugar que possão concorrer para ser conhecido. } \\
\text { Art. } 32 \text {. O registro dos nascimentos e obitos de que trata o presente } \\
\text { Regulamento, começará impreterivelmente no } 1^{\circ} \text { de Janeiro de } 1852 \text {. } \\
\text { Art. } 33 \text {. Pelas disposições d'este Regulamento não se entenderá } \\
\text { que ficão supprimidos os registros Ecclesiasticos, que costumão } \\
\text { fazer os Parochos, os quaes continuarão, como até agora, para a } \\
\text { prova dos baptismos e casamentos. }\end{array}$ & $\begin{array}{l}\text { Manda executar o Regulamento do } \\
\text { registro dos nascimentos e obitos. }\end{array}$ \\
\hline
\end{tabular}




\begin{tabular}{|c|c|c|c|}
\hline Ano & Legislação & Artigo e Descrição & Contextualização/Comentários \\
\hline 1871 & Lei 2040 & Lei do Ventre Livre & $\begin{array}{l}\text { A Princesa Isabel assina a Lei do Ventre } \\
\text { Livre, que considerava livres da } \\
\text { escravidão os filhos de escravas nascidos } \\
\text { a partir de então. }\end{array}$ \\
\hline 1874 & Decreto 5604 & $\begin{array}{l}\text { CAPITULO I } \\
\text { Do registro dos nascimentos } \\
\text { Art. } 48 \text {. Todo recem-nascido, filho de nacional ou estrangeiro, deverá } \\
\text { ser apresentado, dentro dos } 30 \text { primeiros dias depois do nascimento, ao } \\
\text { Escrivão de Paz do districto em que residir sua familia, a fim de fazer o } \\
\text { registro competente. Se o Escrivão residir a mais de uma légua de } \\
\text { distancia do lugar em que fôr dado a luz o recem-nascido, a } \\
\text { apresentação será feita ao Inspector do quarteirão do Lugar, obrigado } \\
\text { este a ir á casa do recem-nascido, quando fôr chamado, com a sua } \\
\text { declaração fará o Escrivão o registro. } \\
\text { O prazo aqui marcado poderá ser prorogado até tres mezes pelo Juiz } \\
\text { de Paz. } \\
\text { Art. 53. Sendo exposto, declarar-se-ha o dia, mez e anno, e o lugar em } \\
\text { que foi exposto; a hora em que foi encontrado, a sua idade apparente e o } \\
\text { envoltorio, roupas quaesquer outros objectos e signaes que tiver, e que } \\
\text { possam a todo tempo fazel-o reconhecer. }\end{array}$ & $\begin{array}{l}\text { Manda observar o Regulamento desta } \\
\text { data para execução do art. } 2^{\circ} \text { da Lei } n^{\circ} \\
1829 \text { de } 9 \text { de setembro de } 1870, \text { na } \\
\text { parte em que estabelece o registro civil } \\
\text { dos nascimentos, casamentos e obitos. } \\
\text { Hei por bem Mandar que, para execução } \\
\text { do art. } 2^{\circ} \text { da Lei } n^{\circ} 1829 \text { de } 9 \text { de } \\
\text { Setembro de } 1870, \text { na parte em que } \\
\text { estabelece o registro civil dos } \\
\text { nascimentos, casamentos e obitos, se } \\
\text { observe o Regulamento que com este } \\
\text { baixa, assignado pelo Dr. João Alfredo } \\
\text { Corrêa de Oliveira, do Meu Conselho, } \\
\text { Ministro e Secretario de Estado dos } \\
\text { Negocios do Imperio, que assim o tenha } \\
\text { entendido e faça executar. }\end{array}$ \\
\hline
\end{tabular}




\begin{tabular}{|c|c|c|c|}
\hline Ano & Legislação & Artigo e Descrição & Contextualização/Comentários \\
\hline 1888 & Decreto 9886 & $\begin{array}{l}\text { Manda observar o novo Regulamento para a execução do art. } 2^{\circ} \text { da Lei n. } \\
1829 \text { de } 9 \text { de Setembro de } 1870 \text { na parte que estabelece o Registro civil } \\
\text { dos nascimentos, casamentos e obitos, do accôrdo com a autorisação do } \\
\text { art. } 2^{\circ} \text { do Decreto n. } 3316 \text { de } 11 \text { de Junho do } 1887 \text {. } \\
\text { Art. } 60 \text {. Tratando-se de exposto, far-se-ha a registro de accôrdo com as } \\
\text { declarações que a Santa Casa da Misericordia, nos logares onde existirem } \\
\text { estabelecimentos para esse fim, communicarem ao official competente, } \\
\text { nos prazos mencionados no art. } 54 \text { e sob as penas do art. } 50 \text {. } \\
\text { Art. } 50 \text {. Toda pessoa, nacional ou estrangeira, que, tendo obrigação de } \\
\text { dar a registro algum nascimento, casamento ou obito, não fizer as } \\
\text { declarações competentes dentro dos prazos marcados neste } \\
\text { Regulamento, incorrerá na multa de } 5 \$ 000 \text { a } 20 \$ 000 \text {, elevada ao duplo no } \\
\text { caso de reincidencia. }\end{array}$ & Inclui detalhes e penalidades \\
\hline 1891 & Decreto 1313 & $\begin{array}{l}\text { Estabelece providencias para regularizar o trabalho dos menores } \\
\text { empregados nas fabricas da Capital Federal. }\end{array}$ & $\begin{array}{l}\text { Determina que o trabalho seja permitido a } \\
\text { partir dos } 12 \text { anos de idade. }\end{array}$ \\
\hline 1916 & $\begin{array}{l}\text { Código Civil } \\
\text { Lei } 3071 / 16\end{array}$ & $\begin{array}{l}231 \text { - IV. São deveres de ambos os cônjuges. } \\
\text { Sustento, guarda e educação dos filhos }\end{array}$ & Revogado pela Lei $10.406 / 2002$ \\
\hline 1927 & $\begin{array}{l}\text { Código de } \\
\text { Menores: } \\
1927 \text { (Código } \\
\text { Mello Mattos) }\end{array}$ & III. Dos infantes expostos & $\begin{array}{l}\text { Estatuto Legal para os menores de } 18 \\
\text { anos de idade. O Código de Menores } \\
\text { proibia o sistema de rodas das Santas } \\
\text { Casas, bem como previa a proteção e } \\
\text { guarda dos menores em instituiçôes de } \\
\text { amparo. }\end{array}$ \\
\hline
\end{tabular}




\begin{tabular}{|c|c|c|c|}
\hline Ano & Legislação & Artigo e Descrição & Contextualização/Comentários \\
\hline 1940 & Código Penal & $\begin{array}{l}\text { 133. Abandonar pessoa que está sob seu cuidado, guarda, vigilância ou } \\
\text { autoridade, e, por qualquer motivo incapaz de defender-se dos riscos } \\
\text { resultantes do abandono. } \\
\text { 136. Expor a perigo a vida ou a saúde de pessoa sob sua autoridade, } \\
\text { guarda ou vigilância, para fim de educação, ensino, tratamento ou } \\
\text { custódia, quer privando-a de alimentação ou cuidados indispensáveis, } \\
\text { quer sujeitando-a ao trabalho excessivo ou inadequado, quer abusando } \\
\text { de meios de correção ou disciplina. } \\
\text { 242. Dar parto alheio como próprio; ocultar recem-nascido ou substituí-lo, } \\
\text { suprimindo ou alterando direito inerente ao estado civil: } \\
\text { Pena - reclusão, de dois a seis anos. } \\
\text { Art } 243 \text {. Deixar em asilo de expostos ou outra instituição de assistência } \\
\text { filho próprio ou alheio, ocultando-lhe a filiação ou atribuindo-lhe outra, com } \\
\text { o fim de prejudicar direito inerente ao estado civil. } \\
\text { Art. } 244 \text {. Deixar, sem justa causa, de prover à subsistência do cônjuge, ou } \\
\text { de filho menor de dezoito anos ou inapto para o trabalho, ou de } \\
\text { ascendente inválido ou valetudinário, não Ihes proporcionando os } \\
\text { recursos necessários ou faltando ao pagamento da pensão alimentícia } \\
\text { judicialmente fixada; deixar, sem justa causa, de socorrer descendente ou } \\
\text { ascendente, gravemente enfermo. }\end{array}$ & $\begin{array}{l}\text { Decreto Lei } 2848 \text { de } 07 \text { de dezembro de } \\
1940 .\end{array}$ \\
\hline 1964 & Lei 4513 & $\begin{array}{l}\text { Criação da Fundação Nacional do Bem-Estar do Menor, quetinha como } \\
\text { dever a formulação e implantação da Política Nacional do Bem Estar do } \\
\text { Menor e assistência à infância, na internação de abandonados, carentes } \\
\text { e infratores. }\end{array}$ & Revogado pela lei 8069 de 1990 \\
\hline 1979 & $\begin{array}{l}\text { Lei } 6697 \\
\text { Código de } \\
\text { Menores }\end{array}$ & $\begin{array}{l}\text { O Código de Menores de } 1979 \text { substitui o Código de Menores de } 1927 \text {. O } \\
\text { novo código ampliou o alcance da proteção aos menores e com a } \\
\text { participação da autoridade judiciária. }\end{array}$ & Revogado pela lei 8069 de 1990 \\
\hline
\end{tabular}




\begin{tabular}{|l|l|l|l|}
\hline Ano & Legislação & \multicolumn{1}{|c|}{ Artigo e Descrição } & Contextualização/Comentários \\
\hline 1988 & $\begin{array}{l}\text { Constituição } \\
\text { Federal }\end{array}$ & Lei maior da República Federativa do Brasil. & $\begin{array}{l}\text { A Constituição da República previu no } \\
\text { artigo 227 a proteção dos menores, futura } \\
\text { da base para o Estatuto da Criança e do } \\
\text { Adolescente. }\end{array}$ \\
\hline 1990 & $\begin{array}{l}\text { Lei } 8069 . \\
\text { Estatuto da } \\
\text { Criança e do } \\
\text { Adolescente } \\
\text { (ECA) }\end{array}$ & $\begin{array}{l}\text { Lei federal versa sobre os direitos das crianças e adolescentes em todo o o } \\
\text { Brasil. }\end{array}$ & $\begin{array}{l}\text { O ECA direitos à vida, à saúde, à } \\
\text { alimentação, à educação, ao lazer, à } \\
\text { profissionalização, à cultura, à dignidade, } \\
\text { ao respeito, à liberdade, à convivência } \\
\text { familiar e comunitária para meninos e } \\
\text { meninas, e contempla questões de } \\
\text { políticas de atendimento, medidas } \\
\text { protetivas ou medidas socioeducativas, } \\
\text { entre outras providências. Trata-se de } \\
\text { direitos diretamente relacionados à } \\
\text { Constituição da República de 1988. }\end{array}$ \\
\hline
\end{tabular}





\section{A roda de Salvador (Santa Casa de Misericórdia da Bahia - SCMBA)}

A história da Santa Casa de Misericórdia da Bahia, localizada na cidade de Salvador, confunde-se com a história da própria cidade. A construção do Hospital da Caridade teve início sob o primeiro Governador-geral, Tomé de Souza, que, em 1549, fundou primeira capital do Brasil, como aponta Russel-Wood (1981, p.274).

A instituição, desde seus primórdios, dedicou-se ao acolhimento de enfermos e idosos e a uma ampla série de funções na área da saúde e da educação. Entre 1690 e 1691, o hospital foi demolido e outro foi construído em seu lugar, recebendo o nome de Hospital São Cristóvão ou da Caridade. O edifício, localizado próximo ao Pelourinho, na Praça da Sé, foi tombado pelo Instituto do Patrimônio Histórico e Artístico Nacional (IPHAN) em 1938. Transformado no Museu da Misericórdia, abriga um exemplar da roda dos expostos.

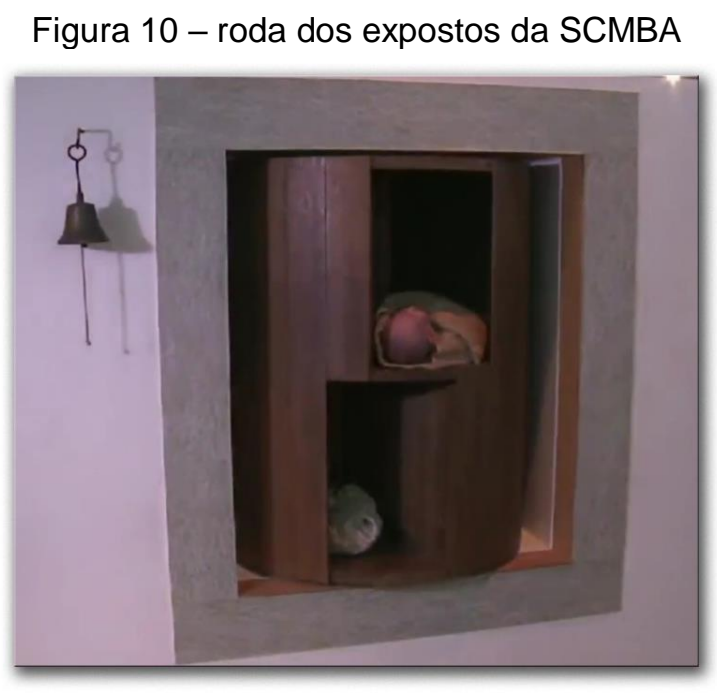

Por sua vez, a Casa da roda de Salvador, foi fundada em 1726, graças aos esforços do Comendador António Joaquim Álvares do Amaral e, de acordo com Almeida (2013, p. 3), é considerada a mais antiga do Brasil. A roda dos expostos foi instalada na portaria do prédio da Casa de Recolhimento do Santo Nome de Jesus, na rua da Misericórdia. O referido estabelecimento, construído por disposição do testamento de João de Matinhos, abrigava moças e viúvas que tivessem sua honra ameaçada.

Uma vez tendo sido depositadas na roda e batizadas, as crianças eram “alojadas nas inadequadas instalações do internato no Hospital São Cristóvão para, 
em seguida, serem enviadas a famílias adotivas ou mães-criadeiras" (SANTANA, 2008, p. 59). No século XIX, a Misericórdia passou a encarregar-se formalmente da educação dos expostos. Como explica Almeida:

em 1847, o Arcebispo D. Romualdo Seixas, Provedor da Santa Casa da
Bahia, estabeleceu as chamadas Casas dos Expostos em educação, uma
para cada sexo. Os meninos entregues à Casa dos Expostos em Educação
aprendiam as primeiras letras e a doutrina cristã. Havia um professor só para
meninos e as meninas, por sua vez, aprendiam na Escola do Recolhimento e
permaneciam na Casa dos Expostos em Educação até a idade de dez a doze
anos, quando passavam para o cuidado da Regente na condição de
recolhidas (ALMEIDA, 2013, p. 2).

Em 11 de fevereiro de 1862, a Mesa da Santa Casa adquiriu da Confraria de São Vicente de Paulo um edifício situado no Campo da Pólvora, que foi inaugurado no dia 29 de junho do mesmo ano. Em 21 de fevereiro de 1875, foram inauguradas as novas instalações do asilo dos expostos. A instituição continuou a receber uma grande quantidade de enjeitados. Com o fim do Império, um projeto modernizador, liderado pela nova elite política e científica, promoveu uma transformação na visão dos cuidados com a infância e nas práticas assistenciais, contando com o protagonismo do Estado (RIBEIRO, 2010, p.7)

Em 1915, um relatório do Dr. Joaquim Martagão Gesteira, então diretor da Inspetoria de Higiene Infantil, apontou a precariedade das condições de higiene local e restrições à prática de depositar crianças na roda dos expostos.

As ações da Liga Baiana contra a Mortalidade Infantil (LBCMI), fundada em 1923, foram de grande importância. Conforme Ribeiro (2010, p. 8), esta organização deu início à construção de um complexo de assistência materno-infantil que se expandiu ao longo da década de 1930, com a inauguração de uma série de novas instalações para abrigar seus serviços no terreno do asilo dos expostos, tais como: lactário Júlia de Carvalho, Museu Áurea de Souza Simas, Abrigo Maternal - Pavilhão Martagão Gesteira e a Pupileira Juracy Magalhães. O mesmo autor (RIBEIRO, 2010, p.8) afirma que o atendimento funcionava de forma integrada, dentro de um novo modelo assistencial médico-científico, e promoveu "o encerramento de dois serviços prestados pela Santa Casa de Misericórdia representantes do modelo de assistência à infância em moldes caritativos, a roda e o Asilo dos Expostos". 


\section{A roda do Rio de Janeiro (Santa Casa de Misericórdia do Rio de Janeiro -SCMRJ)}

O padre José de Anchieta, vendo a esquadra de Castela acometida pela "peste", quando aportou na Guanabara, em março de 1582, começou a construir palhoças para abrigar os doentes e os tratou com ervas, raízes e frutas locais. Não há informações precisas sobre a data de fundação da Santa Casa do Rio de Janeiro, conforme Arantes (2010, p. 6). Para efeitos de estudos históricos, convencionou-se que a data seria 24 de março de 1582.

A roda dos expostos do Rio de Janeiro iniciou-se em 1738, conforme Glauco Carneiro (1986, p. 249). O mecanismo foi instalado na Casa dos Expostos, doada por Romão de Mattos Duarte, provedor da Santa Casa de Misericórdia.

A Casa dos Expostos situou-se por um longo tempo em acomodações anexas ao Hospital Velho da Misericórdia, mudando várias vezes de endereço, quando, finalmente, em 1810, instalou-se na Rua da Misericórdia, 17.

Durante o século XVIII, após um decréscimo inicial na primeira década de funcionamento, o número de expostos deixados na roda cresceu significativamente ao longo das décadas seguintes, como observamos nos dados da tabela abaixo, formulada por Venâncio (2002, p. 136).

Tabela 1 - Número absoluto de expostos deixados na roda da SCMRJ, 1738-1797

NÚMERO ABSOLUTO DE EXPOSTOS DEIXADOS NA RODA DA SANTA CASA DA MISERICÓRDIA DO RIO DE JANEIRO, 1738-1797

\begin{tabular}{ccc}
\hline Periodo & N. Abs. & Indice \\
\hline $1738-1747$ & 379 & 100,0 \\
$1748-1757$ & 356 & 93,9 \\
$1758-1767$ & 811 & 213,9 \\
$1768-1777$ & 1.110 & 292,8 \\
$1778-1787$ & 1.299 & 342,7 \\
$1788-1797$ & 1.535 & 405,0 \\
\hline
\end{tabular}

Fonte: Venâncio (2002, p. 136).

Este crescimento superou o crescimento populacional da cidade do Rio de Janeiro, no mesmo período, como podemos observar nos dados tabulados por Venâncio (2002, p. 136), conforme apresentados a seguir: 
Tabela 2 - Proporção entre população e número de expostos deixados na roda da SCMRJ, 1738-1797

POPULAÇÃO DO RIO DE JANEIRO 1760-1803

\begin{tabular}{lcl}
\hline Ano & N. abs. de habitantes & Índice \\
\hline 1760 & 32.746 & 100 \\
1789 & 36.932 & 112,7 \\
1799 & 43.476 & 132,7 \\
1803 & 46.944 & 144,5 \\
\hline
\end{tabular}

Fonte: Venâncio (2002, p. 136).

No século XIX, a Casa dos Expostos, conforme Arantes, "passou por verdadeira 'via-crúcis', até estabelecer-se no endereço atual":

Esteve na Rua Santa Teresa até 1850; depois, de 1850 a 1860, no Cais da Glória, na Rua da Lapa; Rua dos Barbonos, atual Evaristo da Veira de 1860 a 1906; depois Praia do Flamento n. 82/3 e Rua Senador Vergueiros, de 1906 a 1911; e por fim, a sede definitiva, na Rua Marquês de Abrantes, 48, em terreno que pertencia ao Conde D'Eu, genro do Imperador D. Pedro II. (ARANTES, 2010, p. 7),

Nos últimos anos do Império, a preocupação com os expostos depositados na roda e com suas condições de saúde era crescente. Relatórios encaminhados pelo provedor da Santa Casa ao Ministro do Império informavam que os índices de mortalidade deviam-se ao fato de que as crianças já eram depositadas na roda doentes ou mortas:

\begin{abstract}
Segundo os Relatórios do Ministério do Império, foram recolhidas na roda do Rio de Janeiro 47.255 crianças, no período 1738-1788. As explicações mais comuns apontadas pelos estudiosos para o número crescente de crianças deixadas na roda sempre foram: para que os senhores pudessem alugar as escravas como amas-de-leite; para proteger a honra das famílias, escondendo o fruto de amores ilícitos; para evitar o ônus da criação de filhos das escravas, em idade ainda não produtiva; pela esperança que tinham as escravas de que seus filhos se tornassem livres, entregando-os à roda; para que os recém-nascidos tivessem um enterro cristão, já que muitos eram expostos mortos ou adoecidos, em decorrência de epidemias que se abateram sobre o Rio de Janeiro, fazendo grande número de vítimas, dizimando famílias inteiras e deixando crianças órfãs ou em estado de necessidade (ORLANDI, 1985 apud ARANTES, 2010, p. 9).
\end{abstract}

Embora várias instituições de amparo e de ensino infantil tenham sido criadas ainda no período imperial e após a proclamação da República, a roda dos expostos continuou a acolher os enjeitados. Além da cidade do Rio de Janeiro, outras localidades da Província possuíam roda dos expostos, como Campos e Cabo Frio. 
Com o tempo, a Casa dos expostos transformou-se no Educandário Romão de Mattos Duarte. A instituição passou a receber crianças cujos pais e / ou responsáveis perderam a guarda ou o pátrio poder, por determinação do Poder Judiciário. As crianças permanecem no educandário até que as condições mínimas de proteção a seus direitos sejam garantidas, ou se obtêm uma família substituta por tutela ou adoção, conforme o Estatuto da Criança e Adolescente (ECA). No prédio do Educandário, atualmente, funciona também uma creche popular, destinada à população em situação de vulnerabilidade social. ${ }^{23}$

\section{A roda de São Paulo (Santa Casa de Misericórdia de São Paulo - SCMSP)}

Ao contrário do que ocorreu em Salvador e no Rio de Janeiro, a instalação da roda dos expostos foi tardia em São Paulo.

Apenas no início do século XIX, esforços do provedor da Santa Casa e governador da Capitania, Antonio Jose de Franca e Horta ${ }^{24}$, junto ao Príncipe Regente, tentaram estabelecer uma roda dos expostos na cidade. Após a Independência, em 1823, o Presidente do Governo Provisório, Marechal Cândido Xavier de Almeida e Souza, também tentou junto ao Imperador angariar recursos para implantar a roda. Em 1824, a aquisição da Chácara dos Ingleses, com o legado do Conselheiro Diogo de Toledo Lara Ordonhes ${ }^{25}$, permitiu finalmente a construção do Hospital de Caridade da Santa Casa e a instalação da roda. Em 2 de agosto de 1825, o funcionamento da roda ${ }^{26}$, no muro da rua dona Veridiana, foi autorizado pelo governador da Província de São Paulo, Visconde de Congonhas do Campo, Lucas A. Monteiro de Barros, como explica Mesgravis (1976, p. 414).

\footnotetext{
${ }^{23} \mathrm{http}: / /$ www.romaoduarte.com.br/.

${ }^{24}$ Nasceu em Portugal, foi governador e capitão-general de São Paulo de 1802 a 1808. Faleceu em Portugal.

${ }^{25}$ Nasceu na cidade de São Paulo em 16 de dezembro de 1752. Faleceu na cidade do Rio de Janeiro, em 1826.

${ }^{26}$ AMARAL, Antonio Barreto do. Dicionário de história de São Paulo. São Paulo: Imprensa Oficial, 2006, p. 548, afirma, em verbete sobre a Roda dos Expostos, que "Criada a Santa Casa de Misericórdia de São Paulo, [a Roda dos Expostos] foi instalada em 2-6-1825, e recebida a primeira criança no dia 4 de outubro. Para cuidar dos expostos sempre teve a dirigi-la um mordomo, cujas funções eram contratar amas; fornecer o necessário para o sustento delas e dos menores; cura e educação destes. A grande maioria dos enjeitados era confiada a amas, permanecendo reduzido número na casa dos expostos, no próprio prédio".
} 
Ainda conforme Mesgravis, a Misericórdia acolhia os expostos e os enviava aos cuidados de amas, até os sete anos, quando eram encaminhados ao Seminário da Glória, para meninas, e de Santana, para meninos.

$\mathrm{Na}$ segunda metade do século XIX na falta de serviços de caridade e de serviços públicos nessa área de atuação em São Paulo, a Santa Casa apresentavase como única casa de saúde e obra assistencial. No entanto, seu atendimento funcionava de modo precário. Por iniciativa, do Barão de Iguápe, em 07 de julho de 1872, foi firmado contrato de prestação de serviço entre a Irmandade da Santa Casa e as Irmãs de São José para a administração dos serviços internos com o objetivo de ampliação dos atendimentos prestados, bem como incremento da qualidade dos serviços dispensados aos desvalidos (AZZI, 2012, p. 228-241).

Em 1896 foi inaugurado o Asilo Sampaio Vianna, em uma chácara no bairro do Pacaembu, em terreno legado ${ }^{27}$ pelo padre Joaquim Floriano Wanderley. O edifício passou a abrigar crianças da roda dos expostos a partir dos três anos, ao passo que os recém-nascidos continuavam sendo acolhidos na Seção de Lactantes do Hospital Central da Santa Casa e enviados às amas de leite.

A precariedade do atendimento às crianças, somada à pobreza e ao baixo índice de instrução das amas, fazia crescer o índice de mortalidade entre os expostos. Os avanços da medicina sanitária e do saber científico, ocasionados pela mudança de paradigma da nova ordem republicana, colocavam em cheque o mecanismo da roda e o sistema de amas para a criação dos expostos Como estímulo à melhoria da qualidade dos serviços prestados pelas amas, a Santa Casa instituiu, em 1905, um concurso para premiar, com 100 mil réis a ama que apresentasse o exposto sob sua responsabilidade em melhor condição de saúde (MESGRAVIS, 1976, p. 415).

Um relatório de 1913, de médico do Asilo Sampaio Viana, Rangel Pestana, retratou a elevada mortalidade dos expostos sob responsabilidade da Santa Casa, "ao passo que, em 1912, a porcentagem de óbitos de crianças de 0 a 1 ano, em toda Capital foi de 19,9 por 100 nascimentos, nós registramos 28,5 por 100 entrados." (RANGEL PESTANA apud KUHLMANN Jr.; ROCHA, 2006).

Deve-se destacar que, a partir de 1927, com a publicação do Código de Menores, o abandono de menores tornou-se ilegal, e, por conseguinte, o funcionamento da roda passou a ser posto em causa.

\footnotetext{
${ }^{27}$ http://www.prefeitura.sp.gov.br/cidade/upload/84b46_02_T_Febem_Sampaio_Viana.pdf
} 
Em 1936, o antigo serviço de entrega dos expostos a amas foi substituído por um novo sistema. A partir desta data, os expostos, passaram a ser abrigados em um berçário. Essa nova instituição tinha dormitórios com capacidade para 60 crianças, contava com enfermeiras e pajens para cuidar das crianças, mantinha serviços próprios de costura, lavanderia e limpeza. As condições de saúde dos expostos eram registradas diariamente para informação médica. Nesse mesmo ano foi criado também um lactário. A antigas amas mudaram de papel e passaram a ser doadoras de leite, que era armazenado e distribuído posteriormente. Muitas crianças passaram sua infância no Asilo Sampaio Viana, no Pacaembu e, ao atingirem a idade escolar, iam para o Colégio São José, no qual, além de serem alfabetizadas, aprendiam uma profissão. Por fim, em abril de 1944, a conveniência da extinção da roda foi proposta pelo provedor da Santa Casa José Cassio de Macedo Soares. Diante da proposta, surgiram inúmeros debates, que duraram até junho de 1949. Neste ano, foi produzido um extenso relatório em que se argumentou que "a instituição era a única no Brasil que mantinha a roda", e que ela era considerada "antiquado regime incompatível com o regime social da nova era". Com base nesses argumentos, a essa data, a roda foi extinta na Santa Casa de Misericórdia de São Paulo e no Brasil. ${ }^{28}$

Feitas estas considerações institucionais, jurídicas e históricas para contextualizar as rodas dos expostos e a produção dos escritos da roda, procederemos à descrição da origem dos documentos que compõem o corpus de nosso trabalho. Apresentamos ainda as normas de transcrição adotadas, a reprodução fac-similar, a transcrição semidiplomática dos escritos e suas fichas codicológicas.

\footnotetext{
${ }^{28}$ Informação retirada do site http://santacasasp.org.br/upSrv01/up_publicacoes/4639/5009_roda.pdf. Acesso em 14 de abril de 2017.
} 



\section{ORIGEM, DESCRIÇÃO E TRANSCRIÇÃO DO CORPUS}

Neste capítulo, apresentamos o corpus de nosso estudo, que é constituído de escritos provenientes de quatro rodas dos expostos. Iniciamos em São Paulo, nosso local de origem. Entretanto, considerando que poucos testemunhos foram encontrados, ampliamos nossa pesquisa às capitais coloniais brasileiras, Salvador e Rio de Janeiro e à capital do reino, Lisboa com a hipótese de encontrar mais material nessas cidades, para constituir um corpus mínimo significativo para análise.

Em Salvador, pouquíssimo material foi encontrado, apenas seis escritos. No Rio de Janeiro, um número mais significativo de escritos foi localizado. Por fim, em Lisboa um arquivo com milhares de escritos está disponível à pesquisa.

Identificamos a origem dos escritos, descrevendo os arquivos que preservam seus originais e indicando se são abertos ao público; se são arquivos ou museus, públicos ou privados; e que instituição os mantêm. Em nossa caracterização dos documentos, dizemos ainda onde estão depositados os documentos, como é a estrutura física do espaço depositário, como é a infraestrutura do espaço onde ficam, como estão armazenados, quais são as condições de conservação, com relação à temperatura e à iluminação. Quanto à catalogação dos documentos, indicamos como eles estão separados dos demais documentos do arquivo, como estão organizados, se estão microfilmados ou digitalizados. A seguir, fazemos algumas considerações sobre a constituição do corpus e explicamos quais são as condições de pesquisa nas instituições em que os documentos foram descobertos. Apresentamos, por fim, um quadro com o sumário do corpus, indicando a data e local de produção dos escritos. Seguem as normas utilizadas para a transcrição semidiplomática de cada escrito, seguida da respectiva reprodução fac-similar.

\subsection{OS ARQUIVOS DE GUARDA}

\subsubsection{Arquivos de guarda dos documentos da Roda de Lisboa}

Os documentos da roda de Lisboa estão preservados no Arquivo da Santa Casa de Misericórdia de Lisboa e no Arquivo da Torre do Tombo, em Lisboa. Somados aos sinais que acompanhavam os expostos, constituem um acervo de mais de 86.000 itens, disponibilizados à consulta pública, conforme Manoel e Antão (2010, p. 182). 
Os documentos estão em bom estado de conservação, pois são mantidos em ambiente adequado, com controle de umidade e luz. O acesso direto às salas que contêm o acervo não é permitido.

Embora grande parte do espólio da Misericórdia tenha sido destruída com o incêndio que se seguiu ao terremoto de Lisboa, em 1755, o Arquivo da Santa Casa de Lisboa e o da Torre do Tombo foram os que mais preservaram documentos relativos às rodas dos expostos, tanto em quantidade como em variedade, de acordo com Manoel e Colen (2006, p. 3-5).

Além de realizar a pesquisa diretamente com os escritos da roda, para a seleção dos documentos do corpus, consultamos e fotografamos diversos documentos e objetos relacionados à roda dos expostos, para compreender e contextualizar os escritos como livros de registros e certidões de batismo e sinais.

O arquivo histórico conta com as seguintes seções especializadas: a) livros de entrada e batismo dos expostos; b) livros de entrada de expostos pretos e pardos; c) sinais dos expostos; d) papeletas de matrícula; e) registros de entrega a amas de leite; f) entrega de crianças a amas de criação; g) criação de crianças negras e pardas; h) cartas da encaminhamento entre instituições; i) entregas a fidalgas; j) entregas de expostos dados a ofício; k) entrega de expostas maiores dadas a servir; I) termos de entrega aos pais; $m$ ) registros de emancipações dos expostos, entre outras.

A pesquisa dos escritos da roda de Lisboa foi realizada, presencialmente, em dois meses. As caixas estão organizadas em ordem cronológica e foram consultadas com os cuidados necessários e a supervisão de funcionários do arquivo. Consultamos centenas de escritos e sinais da roda, sendo o mais antigo datado de 1790 e o mais recente de 1926. Embora tenhamos tido acesso a uma grande quantidade de documentos, muitos deles apresentam textos muito similares, reduzidos a algumas poucas palavras ${ }^{29}$, ou são ilegíveis ora por deterioração do suporte, ora por apresentarem borrões ou apagamento da tinta. A partir desse valioso acervo, compusemos parte do corpus desta pesquisa, como será apresentado adiante.

\footnotetext{
29 Os escritos mais breves apresentam apenas uma ou duas das informações a seguir e muito raramente chegam a apresentar três delas: data de nascimento da criança, nome, informação sobre batismo. Muitos escritos com essas características foram encontrados, mas por tratar-se de anotações, e por apresentarem pequeno grau de habilidade de punho, optamos por não incluí-los no corpus.
} 


\subsubsection{Arquivo de guarda dos documentos da roda de Salvador}

Os escritos da roda de Salvador estão preservados no Centro de Memória Jorge Calmon, que é o arquivo histórico da Santa Casa de Misericórdia da Bahia. Esse Centro de Memória está aberto ao público e conta com profissionais das áreas de Biblioteconomia, História e Arquivística, além de estagiários, todos capacitados para descrever os principais documentos do Arquivo e apresentar breve contextualização histórica do material, de modo a prestarem um bom atendimento aos pesquisadores.

O acesso direto às salas que contêm o acervo não é permitido. Estas salas têm controle de temperatura e o acervo documental recebe periodicamente tratamento de proteção aos papirófagos e fungos. A documentação histórica está bem organizada e encontra-se, em sua maior parte, bem conservada. A consulta ao material é supervisionada.

Os livros de registro estão envoltos em papel livre de ácido e amarrados delicadamente com fitilhos próprios. Os documentos avulsos são protegidos por capilhas e acondicionados em caixas de arquivo tratadas quimicamente para maior proteção dos documentos. Os livros de registros da roda também estão digitalizados em arquivos PDF.

A pesquisa para localizar os escritos da roda foi realizada durante diversas visitas ao Centro de Memórias Jorge Calmon e teve um percurso característico. Os documentos relacionados à roda dos expostos estão divididos em três seções: a) Livros de registros e de batismo dos expostos; b) Livros de pagamentos das rodas dos expostos e c) Documentos avulsos.

Apesar da capacitação dos profissionais do Centro de Memória Jorge Calmon, ao se solicitarem os escritos da roda, fomos apresentados às transcrições dos escritos, presentes nos Livros de Registro. Depois de solicitações recorrentes de nossa parte, os profissionais conseguiram localizar seis originais de escritos da roda, que fotografamos e incluímos em nosso corpus. Apresentaram-nos também, a carta datada de 1958 acompanhada do registro de entrada do exposto Jorge Gomes de Jesus, com identificação da mãe, conforme alertarmos antes, a criança não deu entrada na instituição por meio da roda, por isso, a carta reproduzida não faz parte de nosso corpus. Reforçamos ainda que todos os escritos de Salvador que nos foram fornecidos no arquivo da roda de Salvador - e informados como os únicos existentes - como escritos da roda fazem parte do corpus. 
Abaixo temos a imagem de um dos mais antigos livros de registro de expostos da roda de Salvador.

Figura 11 - Livro de registro dos enjeitados, aberto, CMJC-SCMBA, 1757-1763

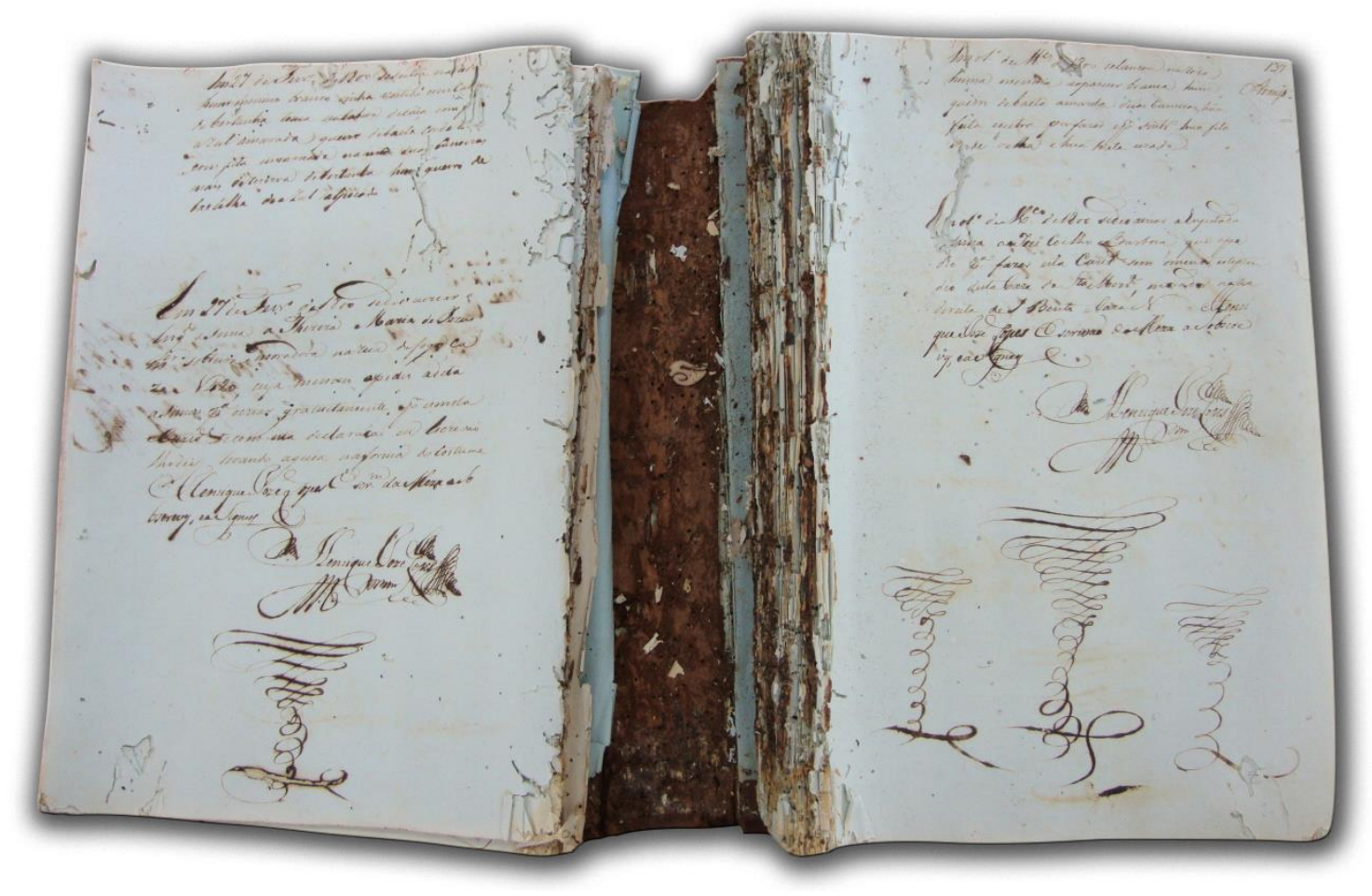

\subsubsection{Arquivo de guarda dos documentos da roda do Rio de Janeiro}

Os escritos da roda do Rio de Janeiro estão depositados em um pequeno museu dedicado à roda dos expostos. O museu está abrigado em uma edificação onde anteriormente ficava instalada a roda, no complexo do Educandário Romão de Mattos Duarte, localizado na rua do Rua Paulo VI n 60, no bairro do Flamengo.

O museu não é aberto ao público nem conta com manutenção regular. O museu abriga diversos objetos históricos como mobiliário, entre eles, berços e estantes; obras de arte, como quadros; brinquedos, como bonecas; peças de vestuários; utensílios, como banheiras; documentos, como fotografias e um conjunto de mais de cem volumes encadernados referentes aos expostos. Todo esse acervo está armazendado em estantes, ou sobre mesas e outras peças do mobiliário. Apenas alguns objetos 
trazem identificação. Duas rodas também fazem parte do acervo, sendo uma delas réplica ${ }^{30}$ e outra original. A imagem a seguir mostra a roda dos expostos original:

Figura 12 - roda dos expostos da SCMRJ

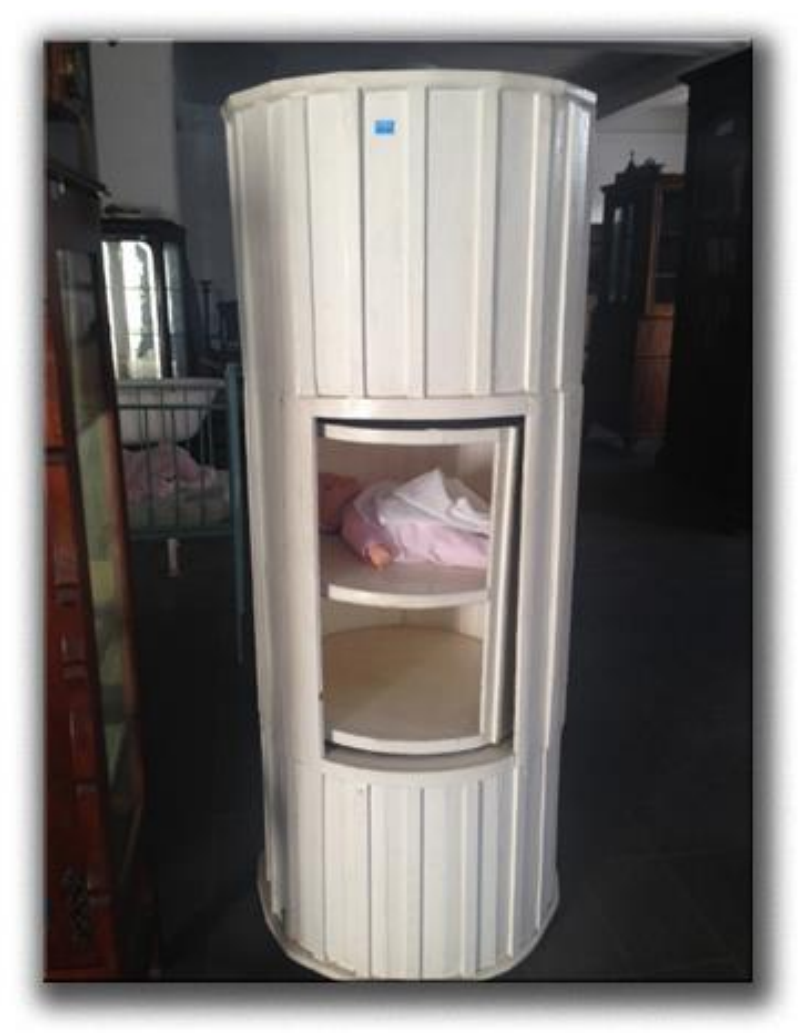

$\mathrm{Na}$ parede junto à porta de entrada do museu está dependurado um sino original do período de funcionamento da roda.

O conjunto de volumes com os escritos consiste em livros encadernados em capa dura azul, identificados com letras douradas na lombada e na capa, divididos por períodos de 5 em 5 anos.

Cada um desses volumes reúne um ou mais livros de matrículas dos expostos - cuja(s) capa(s) foi(ram) removida(s) -, certidões de nascimento, batismo, óbito e prontuários médicos, além de um número variável de escritos. Alguns deles apresentam centenas de escritos da roda, enquanto outros, nenhum. O fato sugere falta de sistematização na organização das encadernações dos volumes.

\footnotetext{
30 Utilizada na telenovela Terra Nostra, rot. Benedito Ruy Barbosa, dir. Jayme Monjardim, 1999-2000, Rede Globo de Televisão.
} 
A forma pela qual esses volumes foram encadernados, por meio de costuras no papel e cola na lombada, prejudicou a leitura dos escritos e danificou muitos deles, especialmente, os menores, como podemos observar na imagem abaixo:

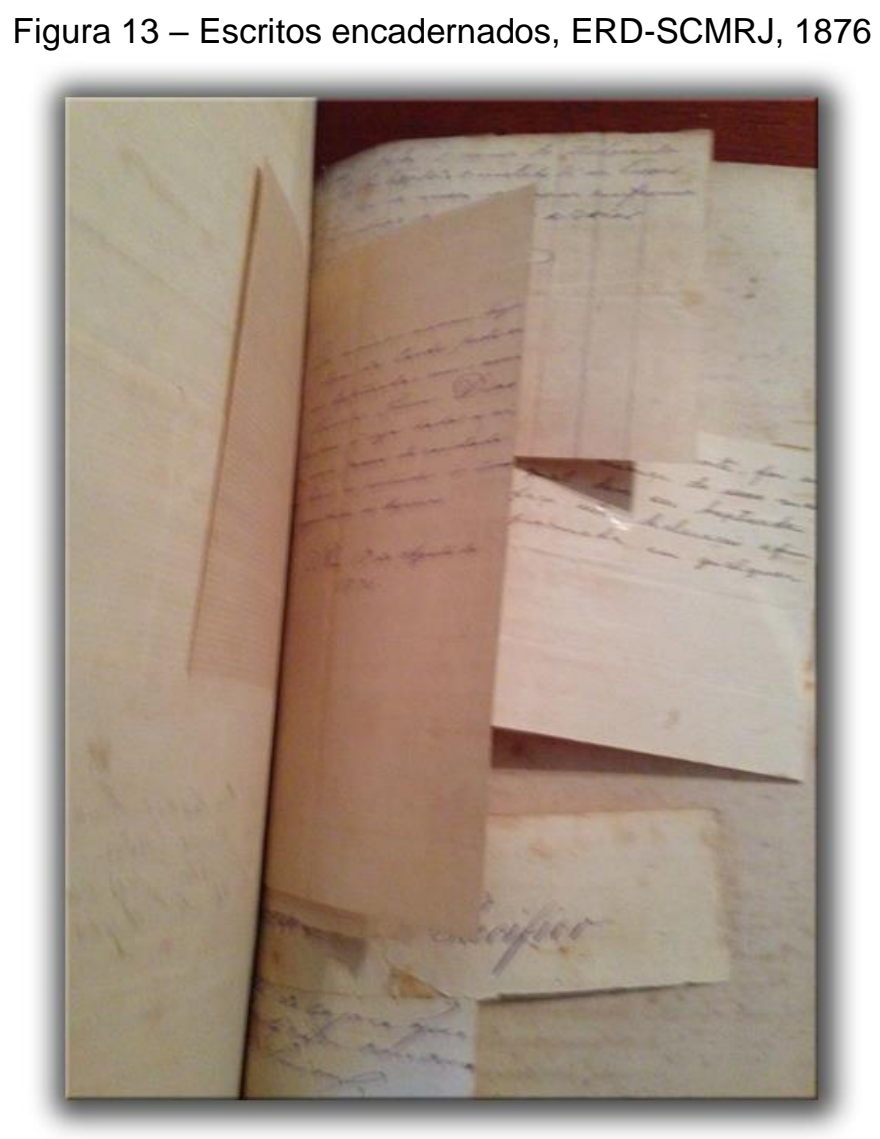

Os documentos não estão catalogados, microfilmados nem digitalizados e, portanto, foi-nos permitido fotografá-los. Os livros de matrícula dos expostos, bem como os outros documentos e os escritos, em sua maioria, estão em razoável estado de conservação, embora o museu não possua controle de umidade e luz.

Conseguimos acesso aos escritos da roda por solicitação, com justificativa, à direção do Educandário Romão de Mattos Duarte, depois de algumas tentativas de contato. O museu não possui infraestrutura para pesquisa e sua iluminação é precária. A pesquisa foi realizada durante duas semanas, com visitas diárias. Tivemos acesso direto a todos os documentos existentes no museu, com um funcionário designado para nos acompanhar durante todo o tempo de consulta ao material. Inicialmente, pretendíamos coletar uma amostra de escritos pertencente a cada meio século. Apesar da grande quantidade de escritos que pudemos pesquisar, muitos deles 
estavam prejudicados pela forma de encadernação e não puderam, portanto, ser lidos e fotografados em sua integralidade, para fins de análise filológica.

Coletamos cerca de 60 escritos, dos quais selecionamos 25 para nosso corpus. Excluímos os que eram muito semelhantes quanto aos elementos extrínsecos e intrínsecos e os constituídos poucas palavras ${ }^{31}$. O mais antigo data de 1858 e o mais recente, de 1955.

${ }^{31}$ Idem nota 23. 


\subsubsection{Arquivo de guarda dos documentos da roda São Paulo}

Os escritos da roda dos expostos de São Paulo estão depositados no Museu da Santa Casa de São Paulo, localizado no Hospital Central da Santa Casa de Misericórdia, na rua Doutor Cesário Mota Júnior.

O Museu é aberto ao público e abriga peças referentes à história da Santa Casa de Misericórdia: mobiliário, indumentária, objetos religiosos e cerimonias, fotografias, esculturas, pinturas, além de periódicos e outros documentos, incluindo documentos da roda dos expostos e um exemplar da própria roda.

Figura 14 - roda da SCMSP sobre estante contendo livros de matrícula dos expostos

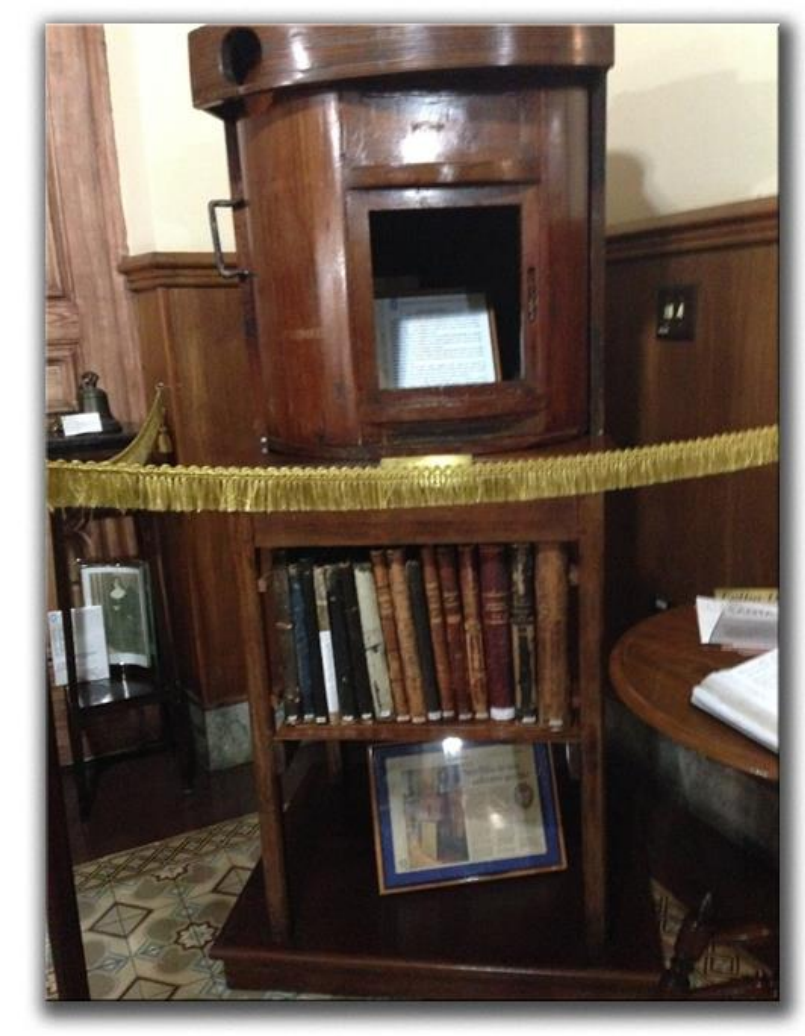


Os escritos estão soltos, entre as páginas dos livros de matrícula dos expostos, organizados em ordem cronológica. A maior parte destes livros de matrícula está disposta em uma pequena estante localizada abaixo do mecanismo da roda dos expostos. Alguns livros estão abertos em vitrinas e exibem a matrícula do exposto com o escrito correspondente.

Figura 15 - Registro de entrada de exposto, exibindo o escrito correspondente, MSC-SP, 1922

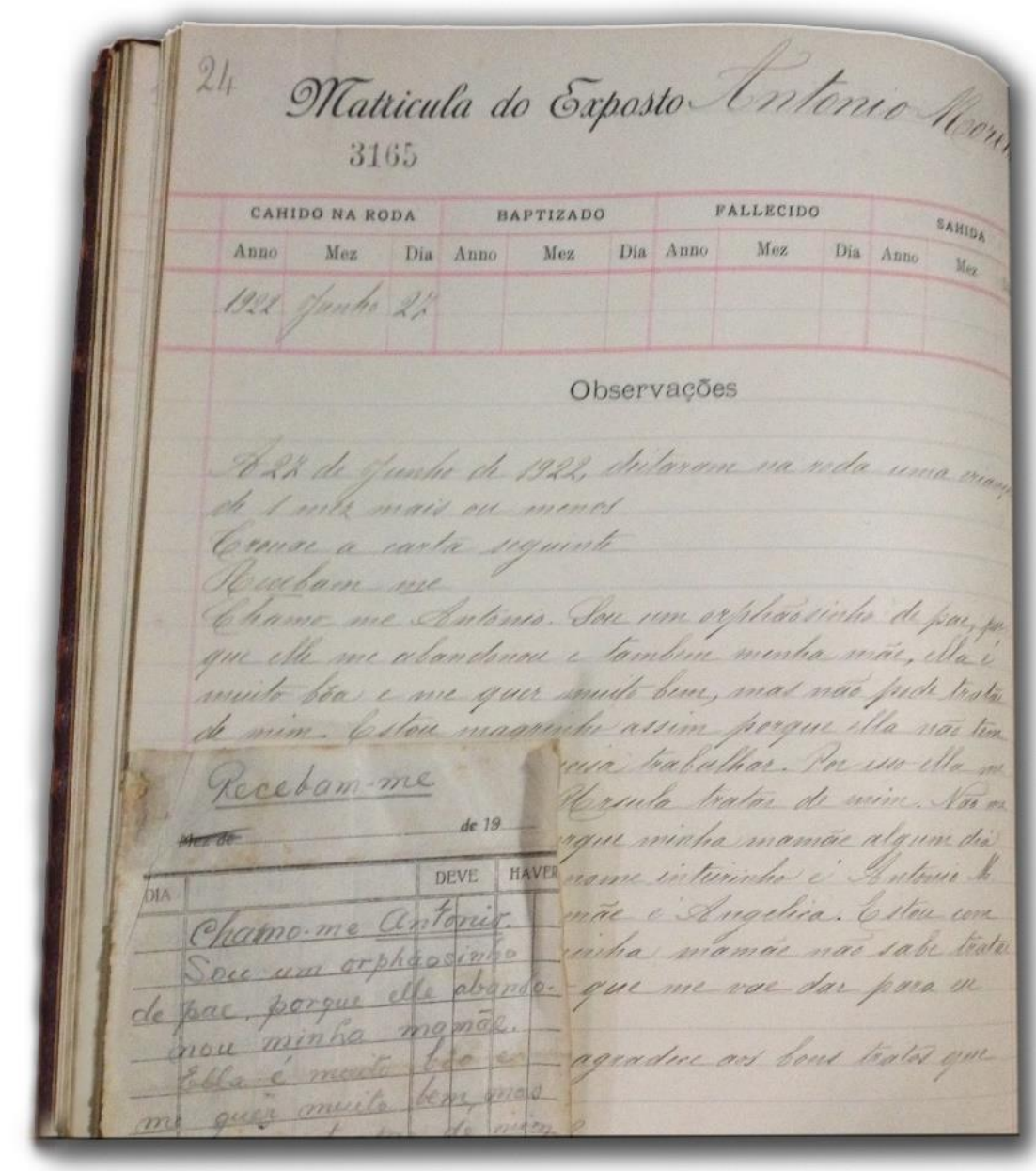


Os livros de matrícula dos expostos, bem como os escritos, estão em bom estado de conservação. Os livros estão encadernados em capa dura, identificados com letras douradas, como podemos visualizar na imagem abaixo.

Figura 16 - Capa de livro de matrícula de expostos da MSC-SP, 1915

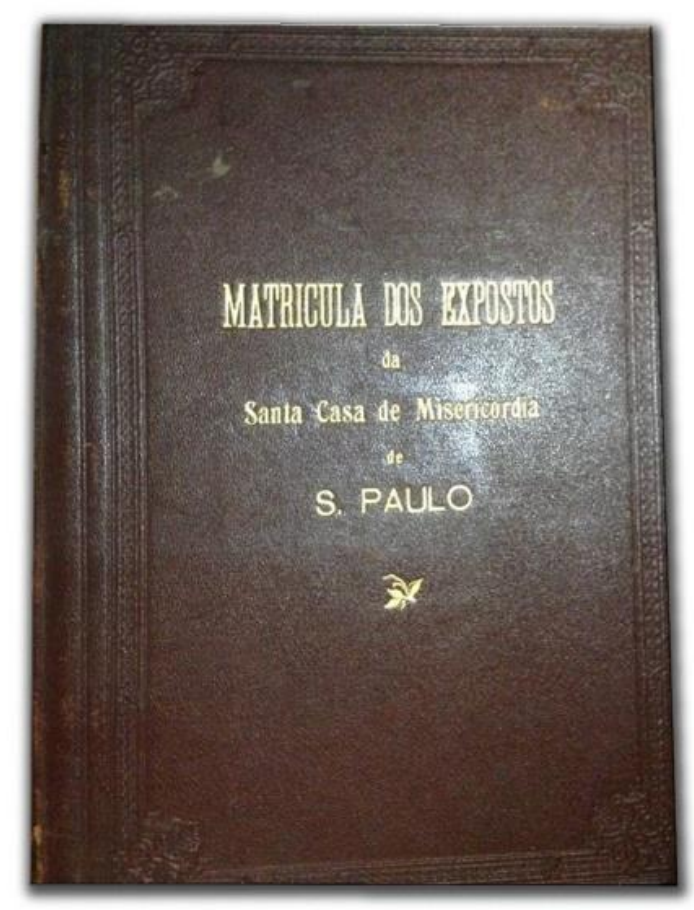

Os documentos não estão catalogados, microfilmados nem digitalizados. Foinos autorizada a pesquisa no acervo, mediante solicitação verbal e escrita à Coordenação do Museu. Além disso, permitiram-nos fotografar os escritos e os livros de matrícula.

A pesquisa foi realizada durante várias visitas ao Museu. Não tivemos acesso direto ao acervo, mas só acesso a escritos avulsos e a livros de matrícula com as páginas abertas, já acompanhados dos respectivos escritos, sob estrita supervisão da responsável pelo museu. 
Um total de 9 escritos $^{32}$ foi coletado, todos apresentados no corpus deste trabalho, exceto o escrito que reproduzimos abaixo, redigido em língua italiana:

Figura 17 - Página de matrícula de exposta acompanhada de escrito redigido em língua Italiana e sinais, MSC-SP, 1915

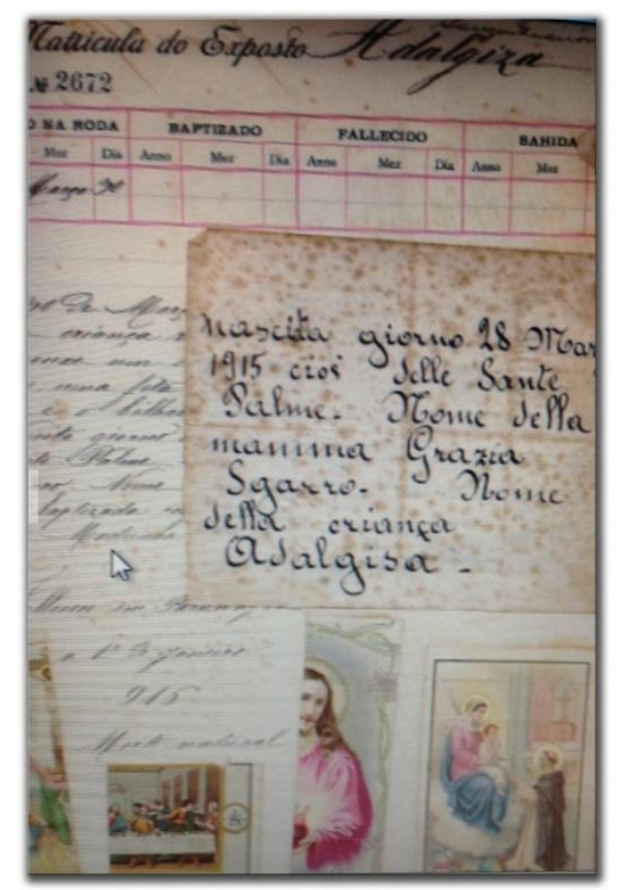

\subsection{A CONSTITUIÇÃO DO CORPUS}

O corpus de nosso trabalho é composto por uma seleção de 60 escritos da roda, recolhidos, como já foi referido, em quatro instituições: uma em Portugal, na Santa Casa de Misericóridia de Lisboa, e três no Brasil, nas Santas Casas de Salvador, Rio de Janeiro e São Paulo.

\subsubsection{Sumário do corpus}

Os escritos das rodas são constituídos por textos originais e, em sua maioria, monotestemunhais, salvo os casos em que o autor do documento produzia duas

\footnotetext{
${ }^{32}$ A existência de tão poucos documentos deve-se ao fato de muitos escritos terem se perdido durante as sucessivas mudanças dos arquivos do museu, conforme a hipótese levantada por funcionária responsável pelo acervo.
} 
cópias do mesmo manuscrito e retinha um delas como documento comprovante da intenção de recuperar a criança posteriormente.

O corpus aqui apresentado é composto por cópias fac-similiares dos escritos originais, que estão organizados por uma dupla ordem cronológica: 1) de procedência, relativa à data de fundação da instituição onde foram localizados, da mais antiga para a mais recente e, dentro delas, 2) de datação do documento, do mais antigo para o mais recente. Os documentos estudados nesta tese envolvem um amplo período histórico, sendo o primeiro datado de 1790 o mais recente, de 1969.

Do total de 60 escritos, 20 foram coletados no Arquivo Histórica da Santa Casa de Misericórida de Lisboa (AH-SCML); 6 descobertos no Centro de Memória Jorge Calmon, da Santa Casa de Misericórdia da Bahia (CMJC-SCMBA); 25 localizados no Educandário Romão Duarte, da Santa Casa de Misericórdia do Rio de Janeiro (ERDSCMRJ) e 9 coletados no Museu da Santa Casa de Misericórdia de São Paulo (MSCSP). ${ }^{33}$ A seguir, os dados da tabela sistematizam o corpus quanto ao local de depósito:

Quadro 3 - Local e instituição de origem dos escritos do corpus

\begin{tabular}{|l|l|c|c|}
\hline \multicolumn{1}{|c|}{ Local } & \multicolumn{1}{|c|}{ Instituição } & Sigla & $\begin{array}{c}\text { Número de } \\
\text { escritos }\end{array}$ \\
\hline Lisboa & Arquivo Histórico da Santa Casa de Misericórdia Lisboa & AH-SCML & 20 \\
\hline Salvador & $\begin{array}{l}\text { Centro de Memória Jorge Calmon da Santa Casa de } \\
\text { Misericórdia da Bahia }\end{array}$ & $\begin{array}{c}\text { CMJC- } \\
\text { SCMBA }\end{array}$ & 6 \\
\hline $\begin{array}{l}\text { Rio de } \\
\text { Janeiro }\end{array}$ & $\begin{array}{l}\text { Educandário Romão Duarte da Santa Casa de } \\
\text { Misericórdia do Rio de Janeiro }\end{array}$ & $\begin{array}{c}\text { ERD- } \\
\text { SCMRJ }\end{array}$ & 25 \\
\hline São Paulo & Museu da Santa Casa de Misericórdia de São Paulo & MSC-SP & 9 \\
\hline
\end{tabular}

Como indicado no quadro, o total foi de 60 escritos, 20 foram provenientes de Portugal e 40 do Brasil, sendo 6 de Salvador, 25 do Rio de Janeiro e 9 de São Paulo. ${ }^{34}$

A título de visualizar-se a organização do material, apresentamos a seguir um quadro com o sumário do corpus, que está organizado da seguinte forma: a primeira coluna refere-se ao número de identificação dado ao manuscrito no conjunto do corpus. A segunda coluna traz a data do manuscrito, geralmente, explícita. Na terceira

\footnotetext{
${ }^{33}$ As siglas utilizadas neste estudo foram propostas por nós, excetuando-se a do Museu da Santa Casa de São Paulo, que consta no site da instituição. <www.santacasasp.org.br/portal/site/museu/museu>. Acesso em 6 de agoto de 2017.

${ }^{34}$ Como explicamos anteriormente, nos itens 3.1.2 e 3.1.4, só foi possível coletar 6 escritos do arquivo da Roda de Salvador e 9 de São Paulo. Optamos por consituir um corpus mínimo de 60 escritos, por esta razão, selecionamos 20 escritos da Roda de Lisboa e 25 escritos da Roda do Rio de Janeiro, com o objetivo de equilibrar nosso corpus.
} 
coluna, faz-se a transcrição da primeira linha do manuscrito. Segue o número indicativo da quantidade de páginas. A quinta coluna informa o número de linhas escritas de cada documento. A penúltima informa a sigla da instituição que guarda o original manuscrito do documento. Por fim, a última coluna indica a página da tese em que o documento é apresentado. 
Quadro 4 - Sumário do Corpus

\begin{tabular}{|c|c|c|c|c|c|c|}
\hline \multicolumn{7}{|c|}{ CORPUS DE LISBOA } \\
\hline 1 & 1790 & Para a Caza das Mezericordia & 1 & 09 & $\mathrm{AH}-\mathrm{SCML}$ & 88 \\
\hline 2 & 1790 & Ahi vay hese Menino com hidade de hum mes & 1 & 11 & $\mathrm{AH}-\mathrm{SCML}$ & 90 \\
\hline 4 & 1798 & Joaquina, anacenso & 1 & 10 & $\mathrm{AH}-\mathrm{SCML}$ & 94 \\
\hline 5 & 1800 & Nanoite do dia 2 de Janeiro de 1800 nas & 1 & 08 & $\mathrm{AH}-\mathrm{SCML}$ & 96 \\
\hline 6 & 1800 & Entrego na Santa Caza de Misericordia Eua importa & 1 & 09 & $\mathrm{AH}-\mathrm{SCML}$ & 98 \\
\hline 10 & 1841 & Este infeliz innocente filho foe um Amor mutuo, e Sincero & 1 & 07 & $\mathrm{AH}-\mathrm{SCML}$ & 106 \\
\hline
\end{tabular}




\begin{tabular}{|c|c|c|c|c|c|c|}
\hline \multicolumn{7}{|c|}{ CORPUS DE LISBOA } \\
\hline 11 & 1842 & Esta menina Nasseo no dia 27 de julho & 1 & 08 & $\mathrm{AH}-\mathrm{SCML}$ & 108 \\
\hline 12 & 1843 & Ilustríssimo Senhor esta criança & 1 & 05 & $\mathrm{AH}-\mathrm{SCML}$ & 110 \\
\hline 14 & 1846 & Pede-se que aeste menino que & 1 & 06 & $\mathrm{AH}-\mathrm{SCML}$ & 114 \\
\hline 15 & 1846 & 1846 & 1 & 07 & $\mathrm{AH}-\mathrm{SCML}$ & 116 \\
\hline 16 & 1886 & Este menino nasceu no dia 22 do mez & 1 & 08 & $\mathrm{AH}-\mathrm{SCML}$ & 118 \\
\hline 20 & 1921 & Esta menina está & 1 & 05 & $\mathrm{AH}-\mathrm{SCML}$ & 126 \\
\hline
\end{tabular}




\begin{tabular}{|c|c|l|c|c|c|c|}
\hline \multicolumn{9}{|c|}{ CORPUS DE SALVADOR } \\
\hline $\begin{array}{c}\text { NÚMERO DO } \\
\text { ESCRITO }\end{array}$ & $\begin{array}{c}\text { ANO DO } \\
\text { ESCRITO }\end{array}$ & LINHA DE ABERTURA & $\begin{array}{c}\text { QTD } \\
\text { DE PÁG }\end{array}$ & $\begin{array}{c}\text { QTD DE } \\
\text { LINHAS } \\
\text { ESCRITAS }\end{array}$ & $\begin{array}{c}\text { ARQUIVO } \\
\text { PÁGINA } \\
\text { DA TESE }\end{array}$ \\
\hline 21 & 1959 & José Bomfim Barbosa & 1 & 09 & CMJC-SCMBA & 128 \\
\hline 22 & 1960 & Maria das Graças naceu no & 1 & 10 & CMJC-SCMBA & 130 \\
\hline 23 & 1961 & Salvador 5-3-961 & 1 & 11 & CMJC-SCMBA & 132 \\
\hline 24 & 1961 & Isabel Cristina Marques & 1 & 22 & CMJC-SCMBA & 136 \\
\hline 25 & 1961 & Salvador 1' de agosto de 1961' & 1 & 134 & CMJC-SCMBA & 134 \\
\hline 26 & 1969 & Madre & 130 CMJC-SCMBA & 138 \\
\hline
\end{tabular}




\begin{tabular}{|c|c|c|c|c|c|c|}
\hline \multicolumn{7}{|c|}{ CORPUS DO RIO DE JANEIRO } \\
\hline $\begin{array}{l}\text { NÚMERO } \\
\text { DO } \\
\text { ESCRITO }\end{array}$ & $\begin{array}{l}\text { ANO DO } \\
\text { ESCRITO }\end{array}$ & LINHA DE ABERTURA & $\begin{array}{l}\text { QTD } \\
\text { DE } \\
\text { PÁG }\end{array}$ & $\begin{array}{c}\text { QTD DE } \\
\text { LINHAS } \\
\text { ESCRITAS }\end{array}$ & ARQUIVO & $\begin{array}{l}\text { PÁGINA } \\
\text { DA TESE }\end{array}$ \\
\hline 27 & 1858 & Remeto esta criança que nacio a 30 de Abril. de 1858 & 1 & 05 & ERD-SCMRJ & 140 \\
\hline 28 & 1858 & A criança que este bilhete acompanha & 1 & 05 & ERD-SCMRJ & 142 \\
\hline 29 & 1858 & Eu chamo-me Severina, est[ou] baptisada & 1 & 08 & ERD-SCMRJ & 144 \\
\hline 30 & 1858 & Esta innocente nasceu a 20 de Feveiro do corrente na & 1 & 09 & ERD-SCMRJ & 146 \\
\hline 31 & 1858 & $\begin{array}{l}\text { O menino está baptisado com o nome de Elias: hoje tem } \\
23 \text { dias }\end{array}$ & 1 & 07 & ERD-SCMRJ & 148 \\
\hline 32 & 1858 & Ilustrissimo Senhor & 1 & 14 & ERD-SCMRJ & 150 \\
\hline 33 & 1858 & Hoje 1 de julho de 1858 & 1 & 05 & ERD-SCMRJ & 152 \\
\hline 34 & 1858 & Este innocente nasceu a 8 de agosto & 1 & 20 & ERD-SCMRJ & 154 \\
\hline 35 & 1958 & Em nome do Altisemo Deos emtrego aminha filha & 1 & 9 & ERD-SCMRJ & 156 \\
\hline 36 & 1958 & Remeto este menino para su & 1 & 7 & ERD-SCMRJ & 158 \\
\hline 37 & 1958 & Rio de Janeiro 4 de Setembro de 1858 & 1 & 14 & ERD-SCMRJ & 160 \\
\hline 38 & 1858 & Pedese ofavor que o [recem] presente seja & 1 & 7 & ERD-SCMRJ & 162 \\
\hline 39 & 1858 & Ponderozos motivos obrigão a aban- & 1 & 18 & ERD-SCMRJ & 164 \\
\hline
\end{tabular}




\begin{tabular}{|c|c|c|c|c|c|c|}
\hline \multicolumn{7}{|c|}{ CORPUS DO RIO DE JANEIRO } \\
\hline $\begin{array}{l}\text { NÚMERO } \\
\text { DO } \\
\text { ESCRITO }\end{array}$ & $\begin{array}{l}\text { ANO DO } \\
\text { ESCRITO }\end{array}$ & LINHA DE ABERTURA & $\begin{array}{l}\text { QTD } \\
\text { DE } \\
\text { PÁG }\end{array}$ & $\begin{array}{c}\text { QTD DE } \\
\text { LINHAS } \\
\text { ESCRITAS }\end{array}$ & ARQUIVO & $\begin{array}{l}\text { PÁGINA } \\
\text { DA TESE }\end{array}$ \\
\hline 40 & 1858 & Roga-se a Illustrissima Administração & 1 & 9 & ERD-SCMRJ & 166 \\
\hline 41 & 1858 & [Humenaije] pedida! & 1 & 10 & ERD-SCMRJ & 168 \\
\hline 42 & 1858 & Rio de Janeiro 31 de Dezembro de 1858. & 1 & 9 & ERD-SCMRJ & 170 \\
\hline 43 & 1880 & Esta menina naçeo no dia & 1 & 8 & ERD-SCMRJ & 172 \\
\hline 44 & 1880 & Dia 14 de Janeiro de 1880 & 1 & 14 & ERD-SCMRJ & 174 \\
\hline 45 & 1880 & Esta criança nasceu no & 1 & 7 & ERD-SCMRJ & 176 \\
\hline 46 & 1880 & Não é o crime que aqui expõe & 2 & 10 & ERD-SCMRJ & 178 \\
\hline 47 & 1880 & Ja está registrado. & 1 & 7 & ERD-SCMRJ & 180 \\
\hline 48 & 1901 & Senhoras da Caridade & 1 & 11 & ERD-SCMRJ & 182 \\
\hline 49 & 1901 & $\begin{array}{l}\text { Esta creança é filha de pais incognitos; não está } \\
\text { baptizada; deve chamar-se }\end{array}$ & 1 & 3 & ERD-SCMRJ & 184 \\
\hline 50 & 1903 & Rio de Janeiro 5 de Dezembro de 1903 & 1 & 16 & ERD-SCMRJ & 186 \\
\hline 51 & 1955 & Deicho esta criaça para ser dada & 1 & 5 & ERD-SCMRJ & 188 \\
\hline
\end{tabular}




\begin{tabular}{|c|c|c|c|c|c|c|}
\hline \multicolumn{7}{|c|}{ CORPUS DE SÃO PAULO } \\
\hline 52 & 1917 & Já foi baptisado chama se & 1 & 09 & MSC-SP & 190 \\
\hline 53 & 1920 & Carlos Penna & 1 & 10 & MSC-SP & 192 \\
\hline 55 & 1922 & S. Paulo 21-2-1922 (Dor de mãe) & 2 & 40 & MSC-SP & 196 \\
\hline 56 & 1922 & São Paulo 30 de Maio de 1922 & 1 & 10 & MSC-SP & 200 \\
\hline 57 & 1922 & Recebam-me & 2 & 31 & MSC-SP & 202 \\
\hline
\end{tabular}





\section{Agrupamento dos escritos de meio em meio século}

Para algumas das análises que serão apresentadas nos capítulos seguintes, utilizaremos como referência o agrupamento dos escritos para cada meio século, pois facilitará observação algumas variações. Seguindo esse critério, temos a seguinte distribuição: sete escritos datados da segunda metade do século XVIII, 8 escritos datados da primeira metade do século XIX, 25 escritos datados da segunda metade do século XIX, 13 escritos datados da primeira metade do século $X X$ e 7 escritos datados da segunda metade do século XX.

Esta distribuição consta nos dados do quadro abaixo que está organizada da seguinte forma: a primeira coluna traz a indicação do meio século em que foi produzido o escrito, o número 1, que se segue ao século indicado, representa sua primeira metade e o número 2, por sua vez, representa a segunda metade do século indicado; a segunda coluna informa o número do escrito e a terceira coluna refere-se a seu ano de produção.

Quadro 5 - Escritos agrupados de meio em meio século

\begin{tabular}{|c|c|c|}
\hline \multicolumn{3}{|c|}{ Segunda metade do século XVIII } \\
\hline MEIO SÉCULO & NÚMERO DO ESCRITO & ANO DO ESCRITO \\
\hline Século XVIII-2 & 1 & 1790 \\
\hline Século XVIII-2 & 2 & 1790 \\
\hline Século XVIII-2 & 3 & 1790 \\
\hline Século XVIII-2 & 4 & 1798 \\
\hline Século XVIII-2 & 5 & 1800 \\
\hline Século XVIII-2 & 6 & 1800 \\
\hline Século XVIII-2 & 7 & 1800 \\
\hline \multicolumn{3}{|c|}{ Primeira metade do século XIX } \\
\hline MEIO SÉCULO & NÚMERO DO ESCRITO & ANO DO ESCRITO \\
\hline Século XIX-1 & 8 & 1838 \\
\hline Século XIX-1 & 9 & 1839 \\
\hline Século XIX-1 & 10 & 1841 \\
\hline Século XIX-1 & 11 & 1842 \\
\hline Século XIX-1 & 12 & 1843 \\
\hline Século XIX-1 & 13 & 1843 \\
\hline Século XIX-1 & 14 & 1846 \\
\hline Século XIX-1 & 15 & 1846 \\
\hline
\end{tabular}




\begin{tabular}{|c|c|c|}
\hline \multicolumn{3}{|c|}{ Segunda metade do século XIX } \\
\hline MEIO SÉCULO & NÚMERO DO ESCRITO & ANO DO ESCRITO \\
\hline Século XIX-2 & 16 & 1886 \\
\hline Século XIX-2 & 17 & 1886 \\
\hline Século XIX-2 & 18 & 1890 \\
\hline Século XIX-2 & 19 & 1892 \\
\hline Século XIX-2 & 27 & 1858 \\
\hline Século XIX-2 & 28 & 1858 \\
\hline Século XIX-2 & 29 & 1858 \\
\hline Século XIX-2 & 30 & 1858 \\
\hline Século XIX-2 & 31 & 1858 \\
\hline Século XIX-2 & 32 & 1858 \\
\hline Século XIX-2 & 33 & 1858 \\
\hline Século XIX-2 & 34 & 1858 \\
\hline Século XIX-2 & 35 & 1858 \\
\hline Século XIX-2 & 36 & 1858 \\
\hline Século XIX-2 & 37 & 1858 \\
\hline Século XIX-2 & 38 & 1858 \\
\hline Século XIX-2 & 39 & 1858 \\
\hline Século XIX-2 & 40 & 1858 \\
\hline Século XIX-2 & 41 & 1858 \\
\hline Século XIX-2 & 42 & 1858 \\
\hline Século XIX-2 & 43 & 1880 \\
\hline Século XIX-2 & 44 & 1880 \\
\hline Século XIX-2 & 45 & 1880 \\
\hline Século XIX-2 & 46 & 1880 \\
\hline Século XIX-2 & 47 & 1880 \\
\hline \multicolumn{3}{|c|}{ Primeira metade do século $X X$} \\
\hline MEIO SÉCULO & NÚMERO DO ESCRITO & ANO DO ESCRITO \\
\hline Século XX-1 & 20 & 1921 \\
\hline Século XX-1 & 48 & 1901 \\
\hline Século XX-1 & 49 & 1903 \\
\hline Século XX-1 & 50 & 1903 \\
\hline Século XX-1 & 52 & 1917 \\
\hline Século XX-1 & 53 & 1920 \\
\hline Século XX-1 & 54 & 1921 \\
\hline Século XX-1 & 55 & 1922 \\
\hline Século XX-1 & 56 & 1922 \\
\hline Século XX-1 & 57 & 1922 \\
\hline Século XX-1 & 58 & 1922 \\
\hline Século XX-1 & 59 & 1923 \\
\hline Século XX-1 & 60 & 1923 \\
\hline \multicolumn{3}{|c|}{ Segunda metade do século $X X$} \\
\hline MEIO SÉCULO & NÚMERO DO ESCRITO & ANO DO ESCRITO \\
\hline Século XX-2 & 21 & 1959 \\
\hline Século XX-2 & 22 & 1960 \\
\hline Século XX-2 & 23 & 1961 \\
\hline Século XX-2 & 24 & 1961 \\
\hline Século XX-2 & 25 & 1961 \\
\hline Século XX-2 & 26 & 1969 \\
\hline Século XX-2 & 51 & 1955 \\
\hline
\end{tabular}




\subsubsection{Normas de transcrição}

As transcrições realizadas neste trabalho são semidiplomáticas e justalineares. Os critérios de transcrição utilizados a seguir foram os definidos em 1998, durante o Seminário para a História do Português do Brasil, por um grupo de pesquisadores, apresentados na obra de Megale e Toledo Neto (2006, p.147-8). As normas estão arroladas a seguir e exemplificadas a partir do corpus deste trabalho. A norma 14 foi proposta por nós e acrescentada por uma necessidade específica do corpus.

1. A transcrição será conservadora. Exemplo: "aCaza daSanta Mezericordia" (Escrito 1), em que se mantém a grafia exatamente igual à do manuscrito, exceto quanto aos alógrafos, que serão uniformizados.

2. As abreviaturas alfabéticas ou não, serão desenvolvidas, marcando-se em itálico as letras omitidas e observando-se o critério de respeitar, sempre que possível, a grafia do manuscrito, ainda que manifeste idiossincrasias ortográficas do autor, como no caso da ocorrência de "numero", grafada sem acentuação gráfica, que leva a abreviatura "N." a ser transcrita "Numero 1:573" (Escrito 4).

3. Não será estabelecida fronteira de palavras que venham escritas juntas, nem se introduzirá hífen ou apóstrofo onde não houver. Exemplo: "papel igual aeste, sehade a | presentar quem ofor reclamar." (Escrito 40).

4. A pontuação original será mantida. No caso de espaço maior intervalar deixado pelo autor, será marcado [espaço]. Exemplo: "de Janeiro de1880 [espaço] não está" (Escrito 43).

5. A acentuação original será rigorosamente mantida, não se permitindo qualquer alteração. Exemplo: "Santa Caza da Mizericordia” (Escrito 9).

6. Será respeitado o emprego de maiúsculas e minúsculas como se apresentam no original. No caso de alguma variação física dos sinais gráficos resultar de fatores cursivos, não será considerada relevante. Assim, a comparação do traçado da 
mesma letra deve propiciar a melhor solução. Exemplo: "Ahi Vay hese Menino Com hidade" (Escrito 2).

7. Eventuais erros ou grafias antigas do autor serão mantidos conforme o original, sem nenhuma correção ou modernização da grafia. Exemplo: "Quando eu Poder eide | ir proqurar" (Escrito 47).

8. Inserções do autor na entrelinha ou nas margens superior, laterais ou inferior entram na transcrição entre os sinais $<>$, na localização indicada. Exemplo: <assinatura> (Escrito 4).

9. No caso de repetição que o autor não suprimiu, passa a ser suprimida pelo editor, que a coloca entre colchetes duplos. Exemplo: "hum Lenco [[Lenco]] nacabeça" (Escrito 37).

10. Correções feitas pelo autor do escrito serão tachadas. Exemplo: estezs (Escrito 4)

11. Intervenções do editor hão de ser raríssimas, permitindo-se apenas em caso de extrema necessidade, desde que elucidativas, a ponto de não deixarem margem à dúvida. Quando ocorrerem, devem vir entre colchetes. Exemplo: "dia 19 de Agosto de 1960 as 5 hora[s]" (Escrito 22).

12. Na transcrição, as linhas serão numeradas de cinco em cinco a partir da quinta. Essa numeração será encontrada à margem direita da mancha, à esquerda do leitor. Será feita de maneira contínua por documento.

13. As assinaturas simples ou as rubricas do punho de quem assina serão sublinhadas. Da mesma forma, serão sublinhadas as assinaturas abreviadas. Exemplo: "Jacinta dos Santos" (Escrito 51).

14. Será inserido entre colchetes o termo [rasgado] quanto houver recorte intencional, sobretudo à guisa de sinal. Exemplo: "o auxilio [rasgado]s e das Boas | Irmãs, [rasgado] filho chama-se; | José e os [rasgado] que” (Escrito 50). 
15. A divisão das linhas do documento original será preservada, ao longo do texto, na transcrição, pela marca de uma barra vertical entre as linhas. A mudança de fólio receberá a marcação com o respectivo número na sequência de duas barras verticais: ||1r.|| ||1v.||

\subsubsection{Reprodução fac-similar e transcrição semidiplomática}

A reprodução fac-similar e a transcrição de cada escrito serão apresentadas lado a lado. Para facilitar a comparação, o fac-símile do documento original é apresentado na página esquerda (numeração par) e a sua transcrição aparece na página direita (numeração ímpar). A transcrição de cada documento é justalinear e numerada de cinco em cinco na margem esquerda. 
TRANSCRIÇÃO SEMIDIPLOMÁTICA DOS ESCRITOS SELECIONADOS DE LISBOA

ESCRITO 1 - AH-SCML - 1790

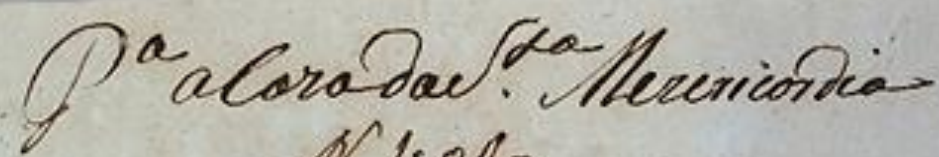 D. 2.040}

C aleu eite Menino pellas ozze horas emeya 20 dia vinte edoif de letembro demil rette centore noventa, vai por Bafitizar, e hade rechamar Maw. ricioi or coejur las debaetso alvadio eicuro ja velhos eenvolta Donerms; offinto Defita atadei ra liza Deteda branca jo velha. perterdere acreacáo delle reja dentro en fo ecomsello pa reprocurar areutempo 
"|1r| Para aCaza daSanta Mezericordia

$<$ Numero 1.040>

Naseu este Menino pellas onze horas emeya do dia vinte e dois de Setembro de mil sette centos e noventa, vai por Baptizar, e hade se chamar Mau-

5 ricio. Os Coeỷros saõ de baetaõ alvadio escuro ja velhos e envolta domesmo; osinto defita atadeira liza deseda branca ja velha. Pertendese que acreação delle seja dentro em Lixboa e com zelo para se procurar aseu tempo ${ }^{35}$ 
ESCRITO 2 - AH-SCML - 1790

\section{1.390}

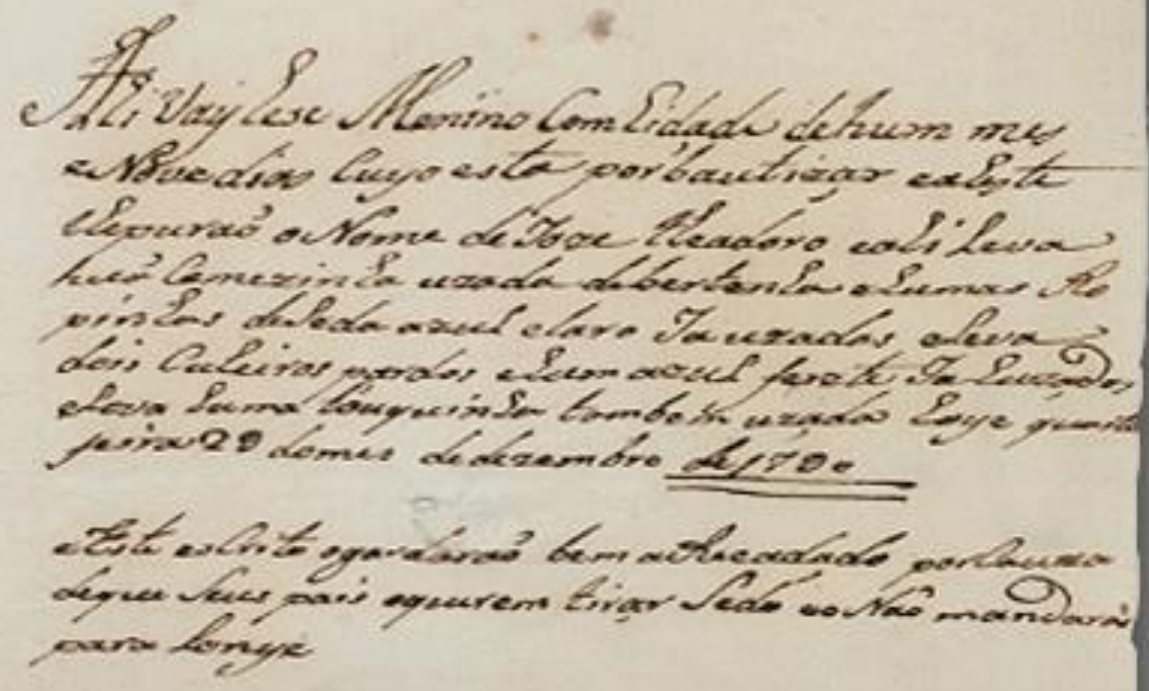


$<$ Numero 1:990>

\|1r $\quad$ Ahi Vaỳ hese Menino Com hidade dehum mes eNove dias Cuyo esta por bautizar eaheste Ihepurão o Nome de Joze theadoro eahi Leva huã Camezinha uzada debertanha e humas Ro

5 pinhas deSeda azul claro Ja uzadas eLeva dois Cuheiros pardos ehum azul ferete Ja Lavados eLeva huma touquinha tambem uzada hoye quarta feira 29 domes de dezembro de1790

e Este esCrito o gardaraõ bem aRecadado porCauza deque Seus pais oquerem tirar Sedo eo Naõ mandará para Lonye 
ESCRITO 3 - AH-SCML - 1790

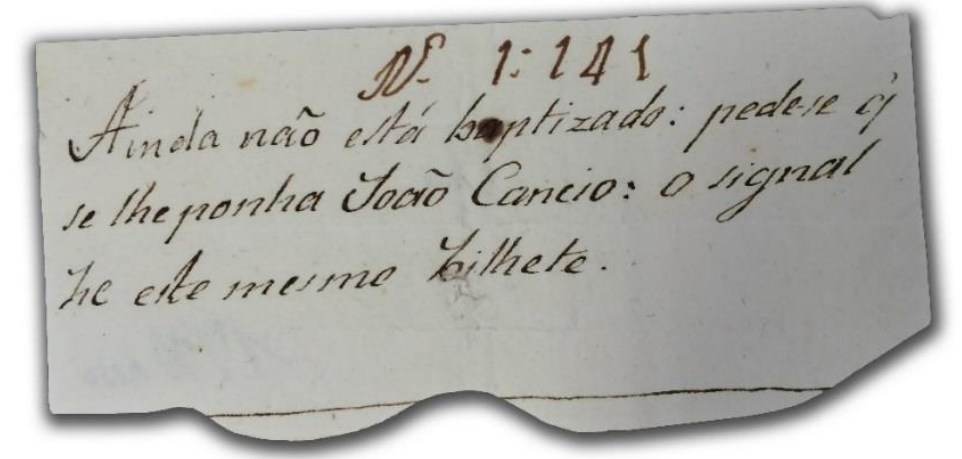


$<$ Numero $1: 141>$

\|1r A Ainda naõ está b[a]ptizado: pede-se que se lhe ponha João Cancio: o signal he este mesmo bilhete. ${ }^{36}$

${ }^{36}$ Recorte irregular do papel na parte inferior 
94

ESCRITO 4 - AH-SCML - 1798

gaguina, DS $1: 523$ aracenso?

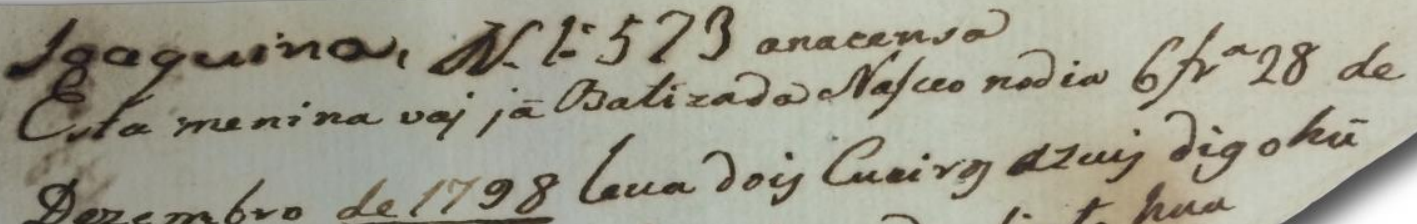

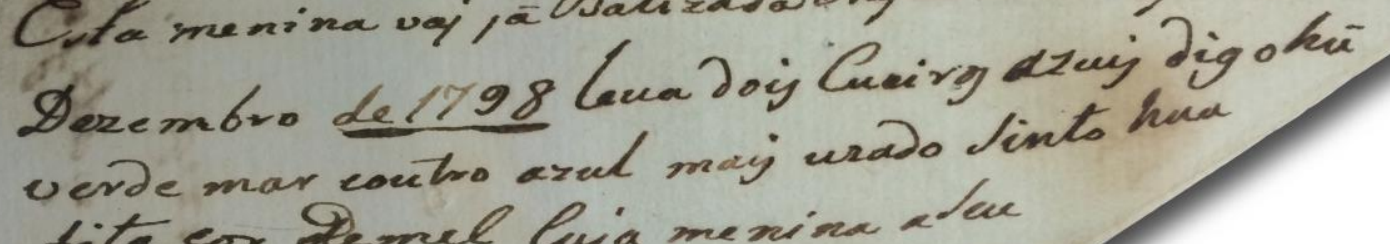
fita er Demel Cuja menina ala temps leprocurar, iste billete ujaim comedt tinayg golpi

à̃ $p^{x}$ comparicer

Com oocetro q́fica

oomermalker शै 
||1r|| loaquina, <Numero 1:573> anacensa

Esta menina vaj já Batizada Nasceo nodia 6 feira 28 de

Dezembro de1798 leua dois Cueiros azuis digo hũ

verde mar eoutro azul mais uzado Sinto hua

5 fita cor demel Cuja menina a Seu

tempo seprocurarâ, este bilhete

uaj asim com estezs sinais golpi

ados para comparicer

com o outro que fica

10 do mesmo Theor

$\underline{\mathrm{DLL}}^{37},{ }^{38}$

\footnotetext{
${ }^{37}$ Papel azul claro

${ }^{38}$ Papel em formato triangular com uma saliência na parte central
} 
ESCRITO 5 - AH-SCML - 1800

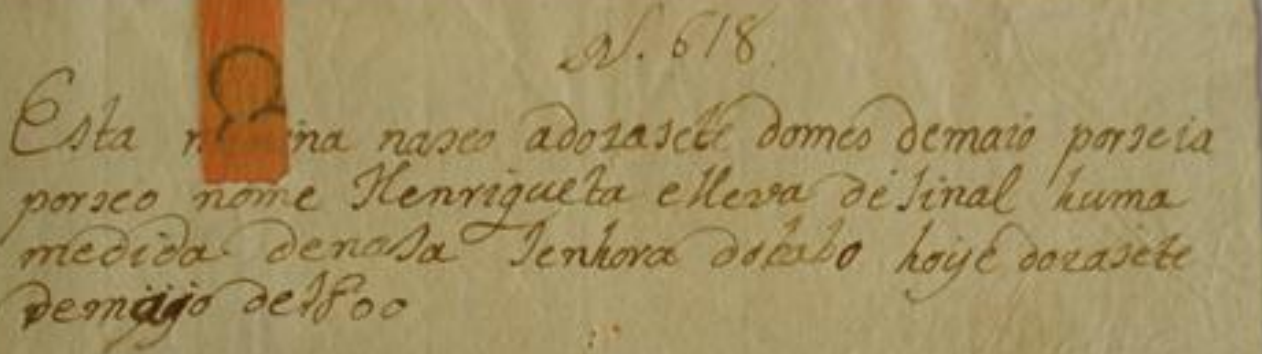


$<$ N. 618>

\|1r\| Esta ${ }^{39}$ menina naseo adozasete domes demaio porseia porseo nome Henriqueta e lleva de Sinal huma medida denosa Senhora do cabo hoye dozasete de mäio de 1800.

${ }^{39}$ Fita cor de rosa perpassada verticalmente encobrindo as letras emi da palavra "menina". 
ESCRITO 6 - AH-SCML - $1800^{40}$

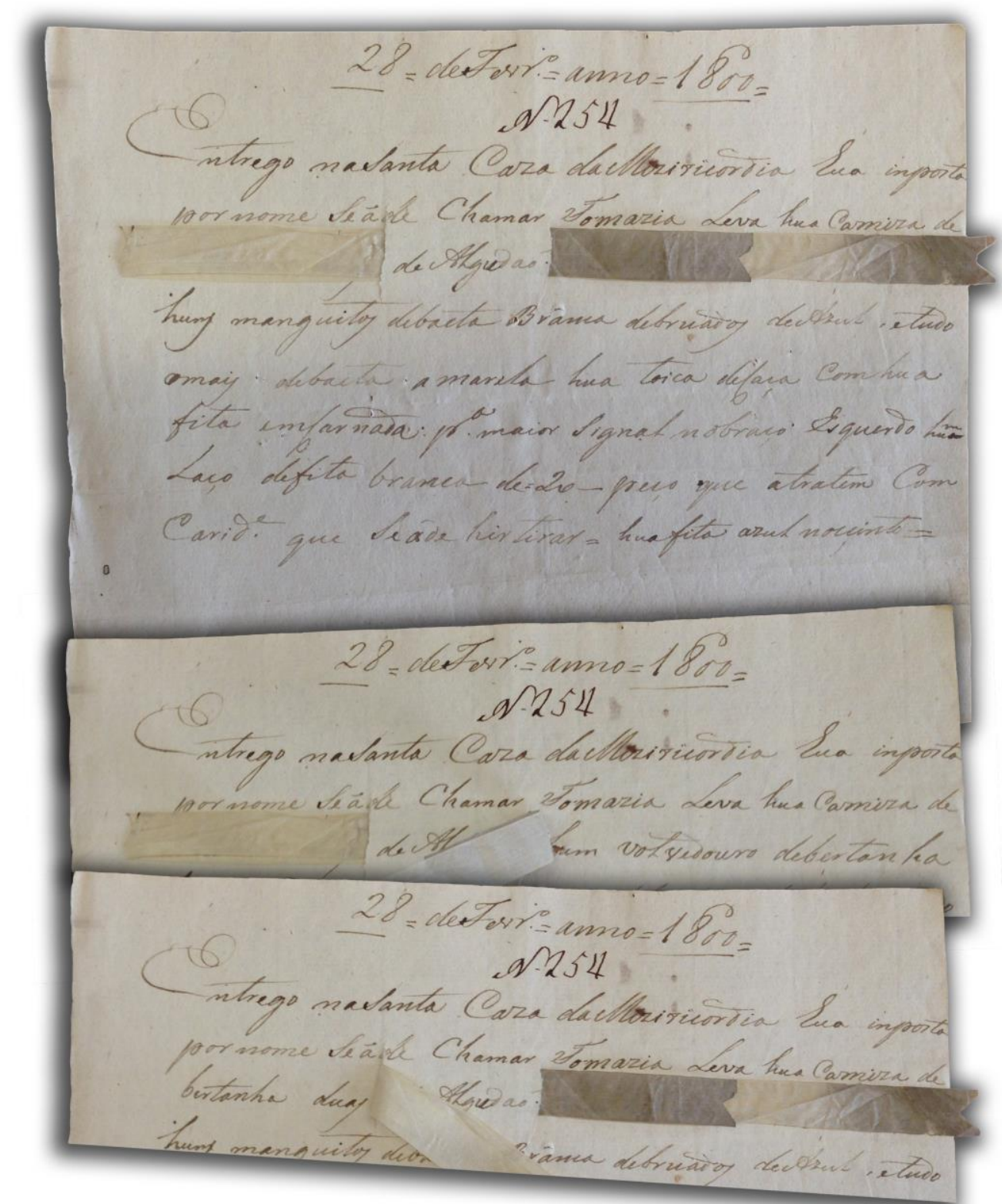

40 Há a reprodução do início do escrito outras duas vezes: cada uma delas com a fita perpassada levantada de um dos lados para tornar possível a leitura da linha encoberta na primeira imagem. 
$\|1 \mathrm{r}\| \quad 28=$ deFevereiro $=$ anno $=1800=$

$<$ Numero 254>

Entrego naSanta Caza da Miziricordia hua inposta por nome Se ã de Chamar Tomazia Leva hua Camiza de bertanha duas de Algudaõ. hum volvedouro debertanha

5 huns manguitos debaeta Brânca debruados deAzul, e tudo omais debaeta amarela hua toica decaça Comhua fita emcarnada: para maior signal nobraço Esquerdo hum Laço defita branca de $=20-$ peço que atratem Com Caridade que Seade hir tirar $=$ huafita azul noccinto $={ }^{41}$ 
100

ESCRITO 7 - AH-SCML - 1800

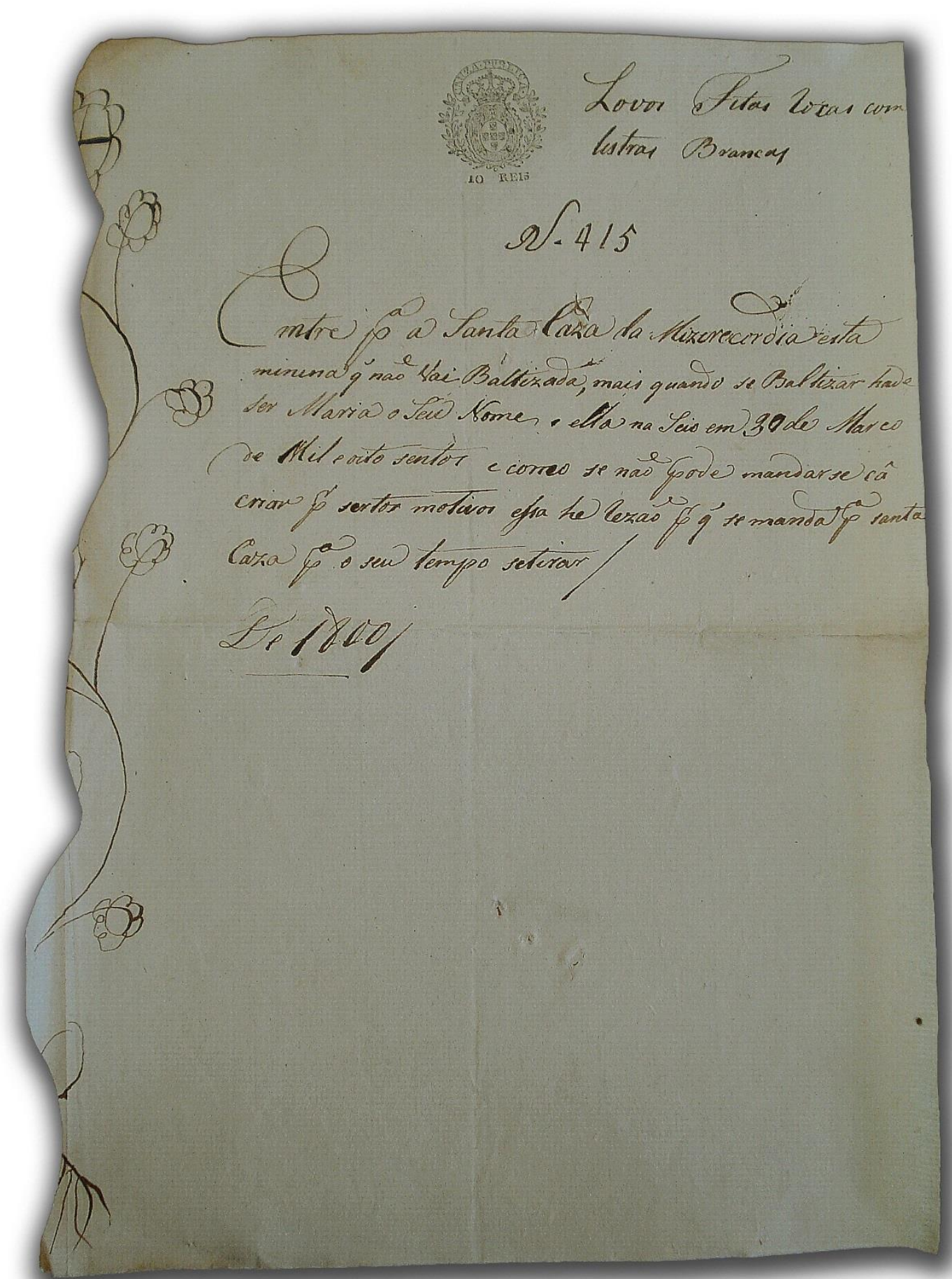


$\|1 \mathrm{r}\|$

${ }^{42}$ Leva Fitas rosas com

listras Brancas

$<$ Numero 415>

Emtre para a Santa Caza da Mizericordia esta

Minina que naõ Vai Baltizada, mais quando a Baltizar hade

5 ser Maria o Seu Nome ella na Seio em 30 de Marco

de Mil e oito sentos e como se nao pode mandarse câ

criar por sertos motivos essa he rezao por que se manda para santa

caza para o seu tempo setirar/

De $1800 / 43$

${ }^{42}$ Há um carimbo com um brasão e abaixo dele consta o valor de 10 reis.

${ }^{43}$ Recorte irregular do papel e desenho de rama de flores na parte esquerda 
ESCRITO 8 - AH-SCML - 1838

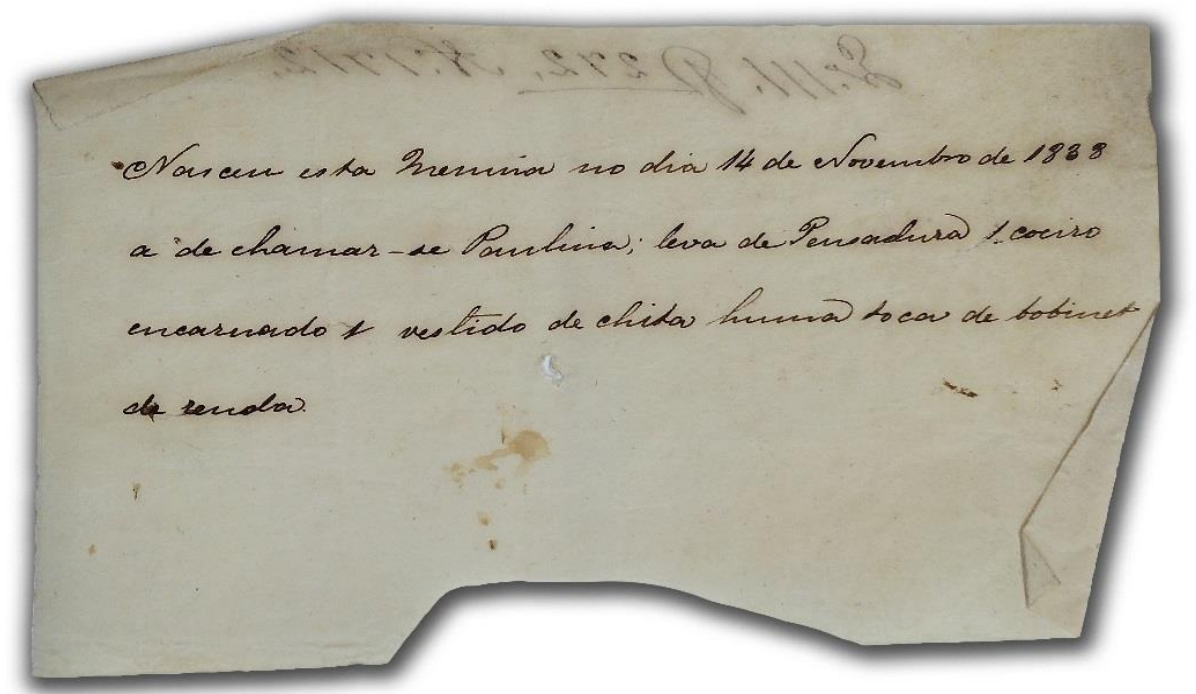


\|1r\| Nasceu esta Menina no dia 14 de novembro de 1838 a de chamar-se Paulina; leva de Pensadura 1 coeiro encarnado 1 vestido de chita huma toca de bobinete de renda. ${ }^{44}$ 
ESCRITO 9 - AH-SCML - 1839

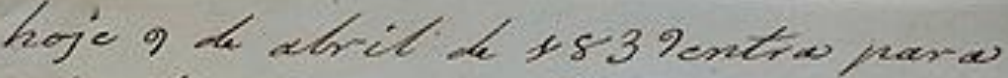

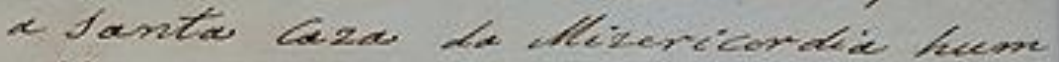
Menino pee Maceo nerte puesmo dise nor nome the pereo jellio

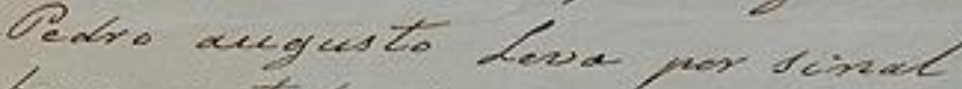

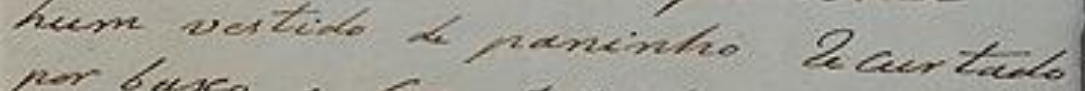

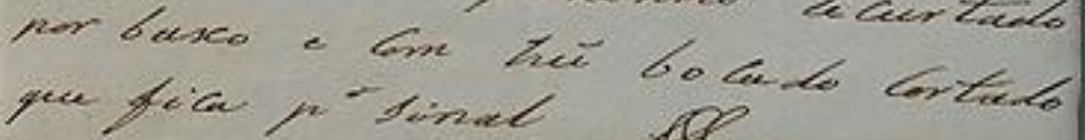


||1r\| hoje 9 de abril de 1839 entra para a Santa Caza da Mizericordia hum Menino que Nasceo neste mesmo dia per nome Ihe poraõ Julio 5 Pedro augusto Leva por sinal hum vestido de paninho recurtado por baxo e Com hũ bocado cortado que fica por sinal

J S Silva 
ESCRITO 10 - AH-SCML - 1841

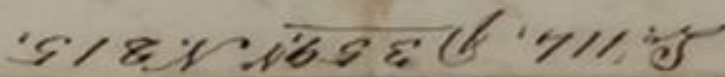

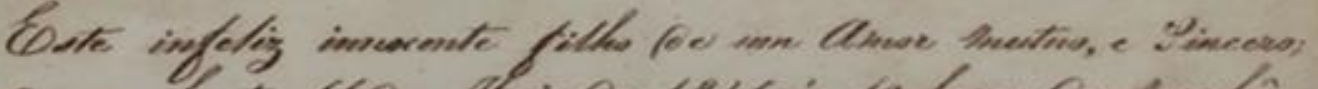

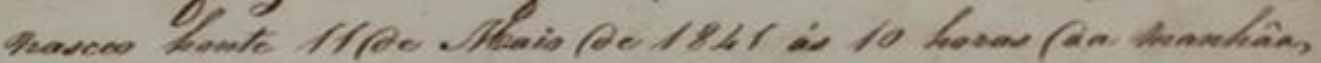

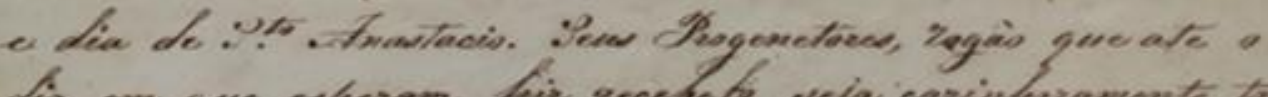

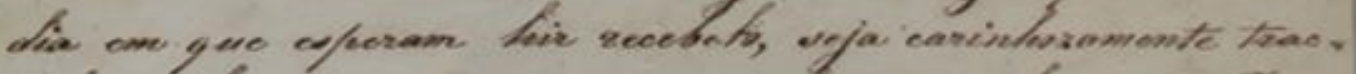

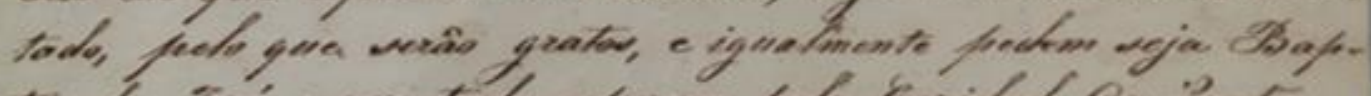

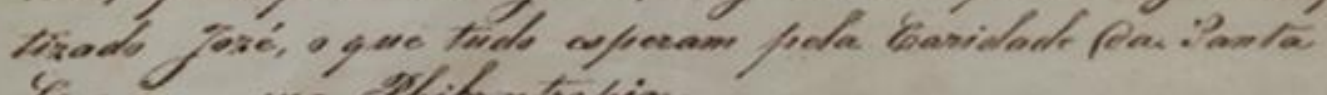

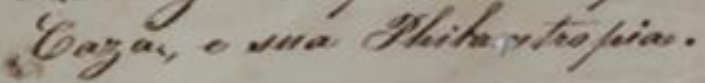




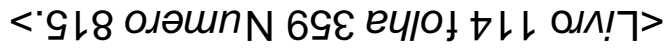

\|1r\| Este infeliz innocente filho de um Amor mutuo, e Sincero; nasceo honte 11 de Maio de 1841 ás 10 horas da manhâa, e dia de Santo Anastacio. Seus Progenetores, rogão que ate o

5 dia em que esperam hir recebelo, seja carinhozamente tractado, pelo que serão gratos, e igualmente pedem seja Baptizado Jozé, o que tudo esperam pela Caridade da Santa Caza, e sua Philantropia. ${ }^{45}$

${ }^{45}$ Papel dobrado ao meio, anotação tardia indicando o número do livro, da página e número do registro do exposto. 
ESCRITO 11 - AH-SCML - 1842

Esta monina of afseo wo dia $27 \mathrm{~d}$ gultio as Eo horas da tride no anro 181,2 huvan

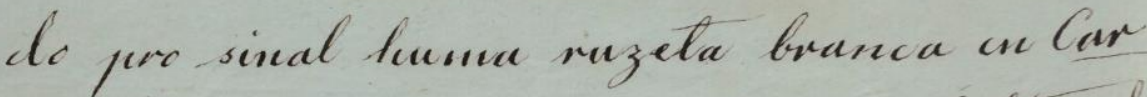
nada e liesde, a enda nai wai battizada Rogo the a Obezeqio qे quaredo a battizar

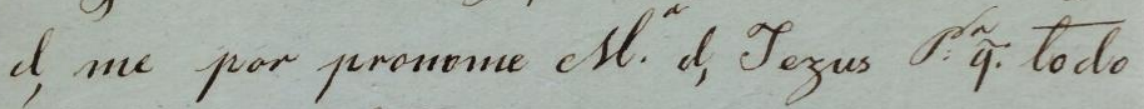

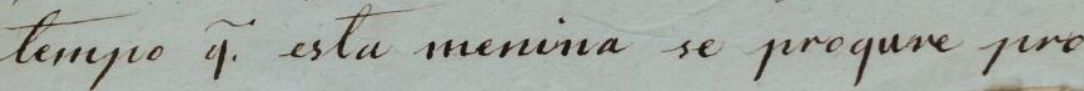
sinal q" leva. 
\|1r Esta menina Nasseo no dia 27 de gulho as 6 horas da trade no anno 1842 luvan do pro sinal huma ruzeta branca en Car nada e Verde, a enda não vai baltizada

5 Rogo-lhe u Obezeqio que quando a baltizar de me por pronome Maria de lezus para que todo tempo que esta menina se proqure pro sinal que leua. ${ }^{46}, 47$

\footnotetext{
${ }^{46}$ Papel de cor azul clara

${ }^{47}$ Roseta branca, encarnada e verde de tecido cosida ao suporte.
} 
ESCRITO 12 - AH-SCML - 1843

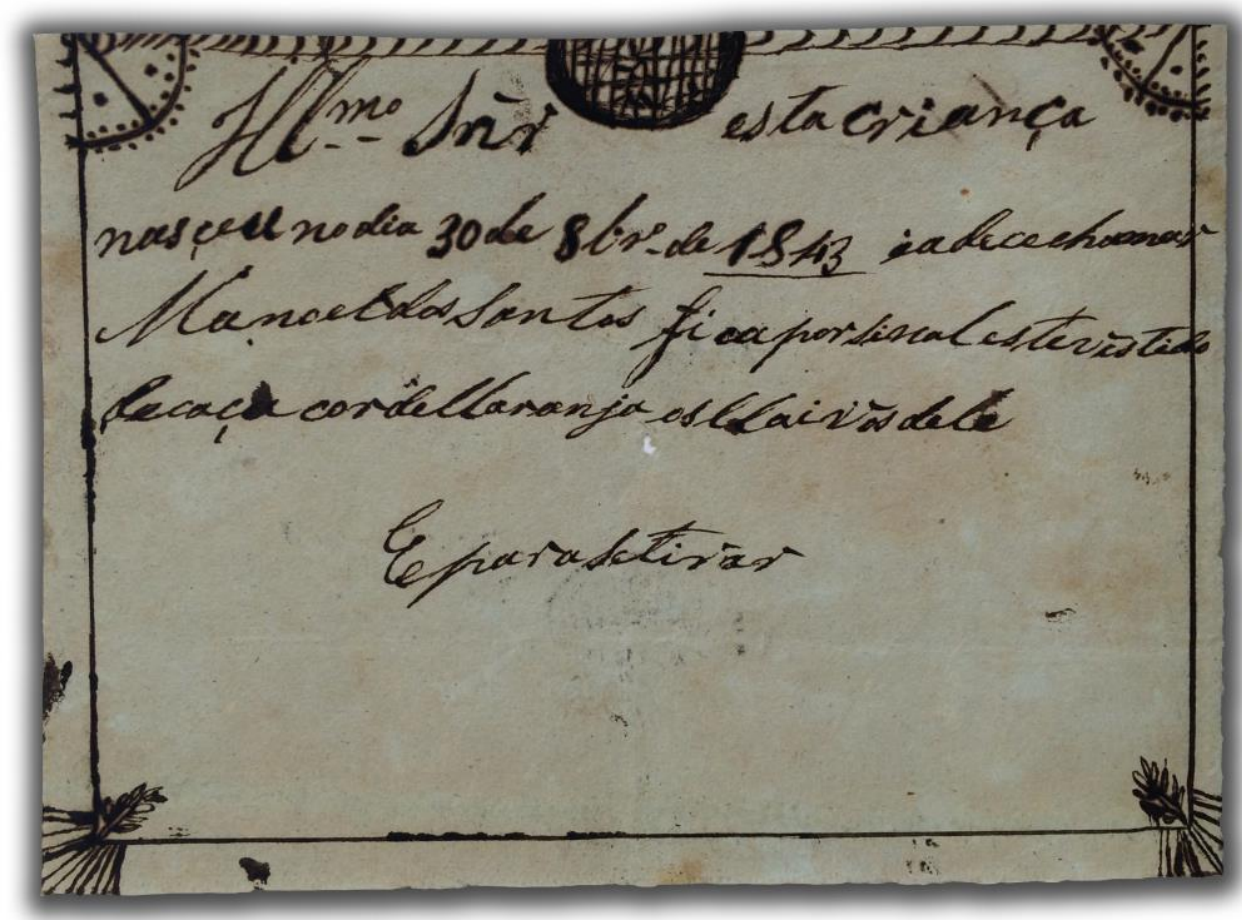


\|1r\| IIlustríssimo Senhor esta criança

nasçeu no dia 30 de outubro de $\underline{1843}$ iadecechamar

Manoeldos Santos ficapor sinal esteuistido

decaça cordellaranja osllaiuos dele

5

EparaSetirar $^{48}$

${ }^{48}$ Desenho de moldura e rrabiscos em cada um dos cantos e na parte central superior do papel 
ESCRITO 13 - AH-SCML - 1843

\section{OAnno de 1843}

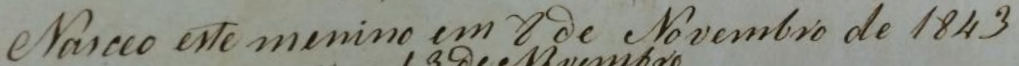

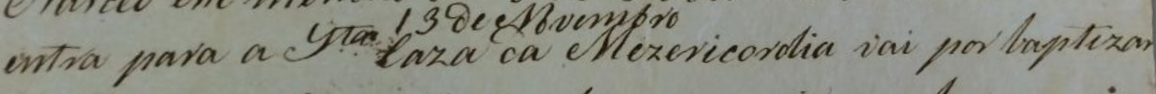
- Nóme sera fore Naria leva um esciro axul um main driao de chita de cualpieos rexa um bocado de fita axul Clava com ram inhor a cers tempro sena procuivado na Y.a Cara da e Mexericonoca. 
Nasceo este menino em 8 de Novembro de 1843

entra para a Santa $<13$ de Novembro $>$ Caza da Mezericordia vai por baptizar o Nome sera Joze Maria leva um coeiro azul um man-

5 drião de chita de salpicos roxa um bocado de fita azul Clara com raminhos a seu tempo sera procurado na Santa Caza da Mezericordia ${ }^{49}$ 
ESCRITO 14 - AH-SCML - 1846

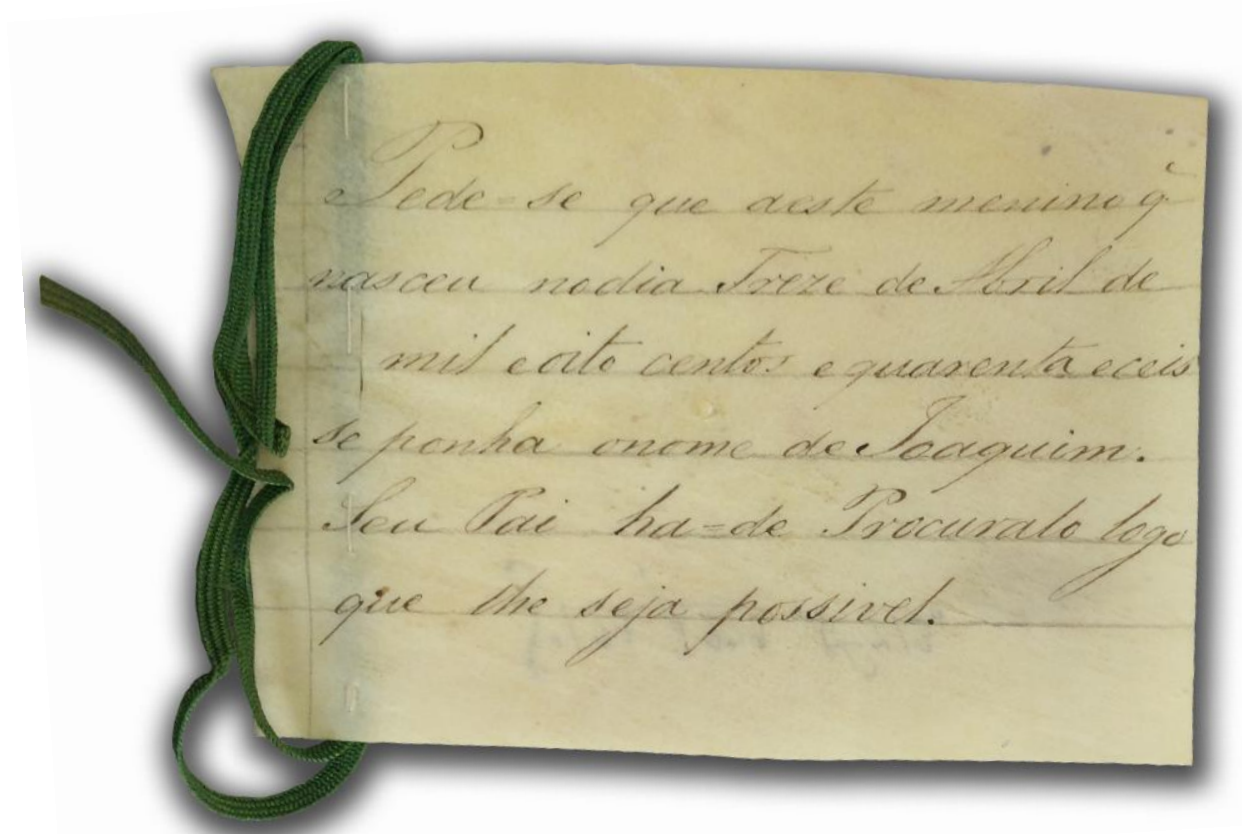


|1r|| Pede-se que aeste menino que nasceu no dia Treze de Abril de mil eoito centos e quarenta eceis se ponha onome de loaquim.

5 Seu Pai ha-de Procuralo logo que Ihe seja possivel. ${ }^{50}$ 
ESCRITO 15 - AH-SCML - 1846

Brta brimea nus esto bap: tirada fidice q. It quarde

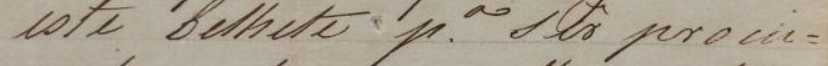
rado um temfios. I dehe fornhas - mosice do día eng. der vistra an $\mathrm{feO} \cdot \mathrm{C}$ 
$<1846->$

\|1r\| Esta criança não esta baptizada pedece que se guarde este Belhete para Sêr procurado em tempo; e selhe ponha

5 o nome do dia em que der entrada assinatura ${ }^{51}, 52$

\footnotetext{
${ }^{51}$ Alfinete perpassando o papel logo após a assinatura

52 Traçados na lateral esquerda suporte do escrito que apresenta um recorte irregular
} 
ESCRITO 16 - AH-SCML - 1886

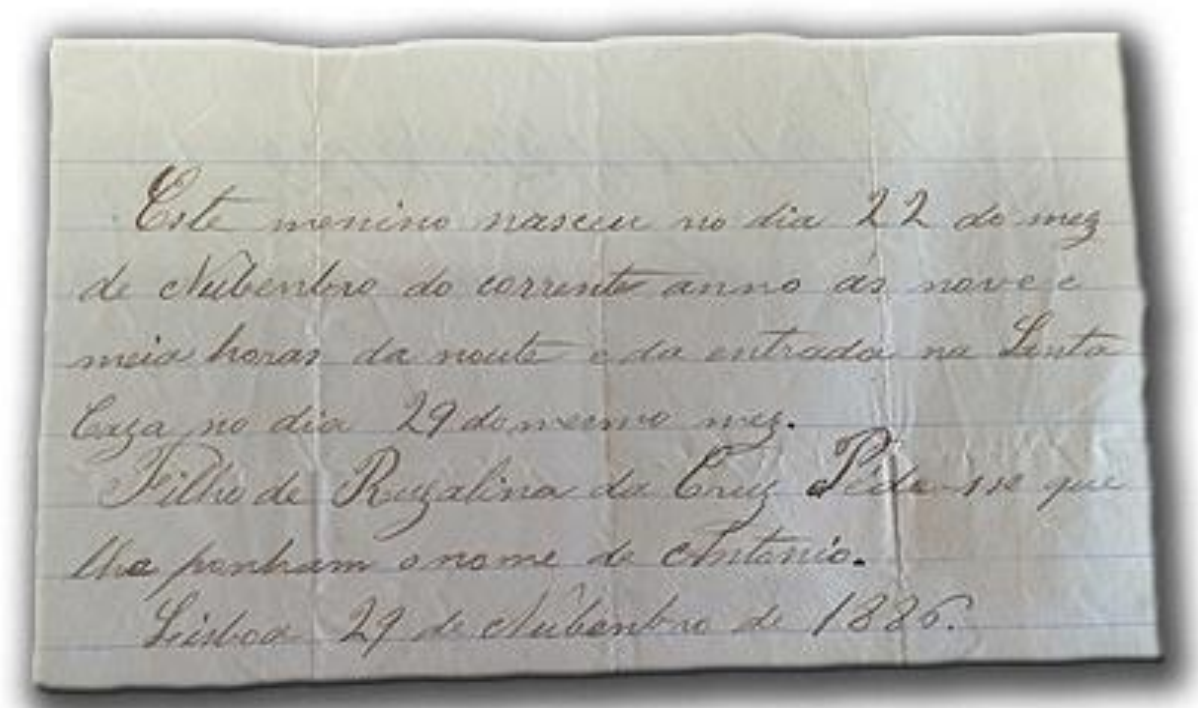


\|1r\| Este menino nasceu no dia 22 do mez de Nubenbro do corrente anno ás nove e meia horas da noute e da entrada na Santa Caza no dia 29 do mesmo mez.

5 Filho de Ruzalina da Cruz Péde-sse que Ihe ponham o nome de Antonio.

Lisboa 29 de Nubenbro de 1886. 
ESCRITO 17 - AH-SCML - 1886

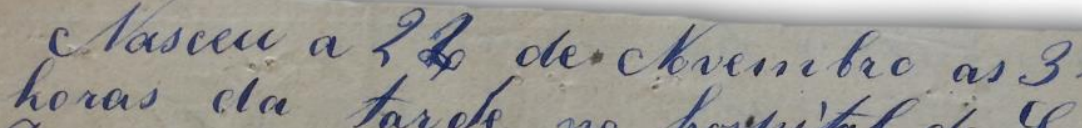

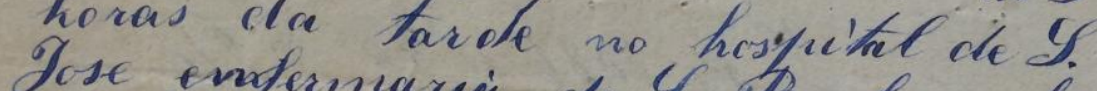
do a of de clovemabe Sarbare bationa

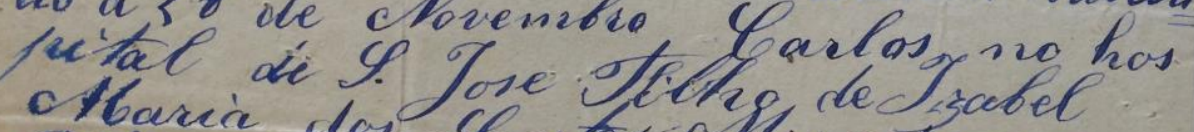

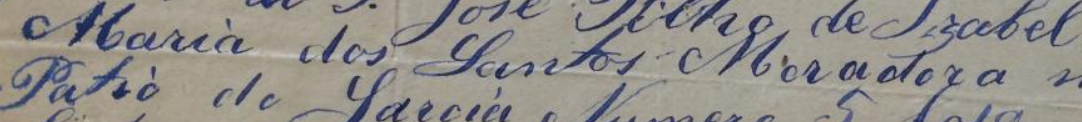
ontrando 0 arera e la ma Jrara a Janta cara da

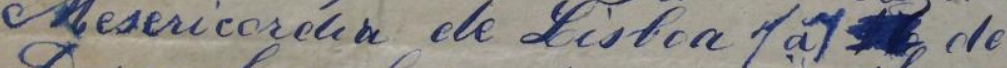

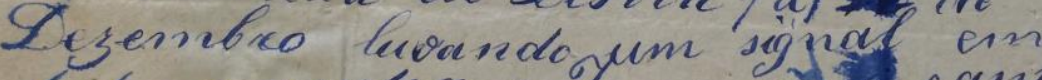

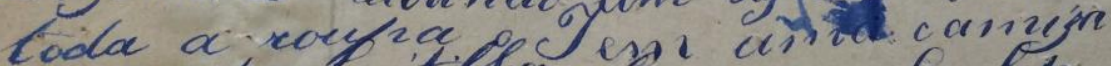

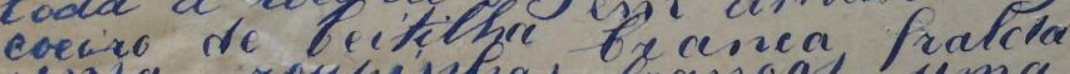
inia roxpipinas breiscas uma vestedinitol becesco o nieco pisco. 1886

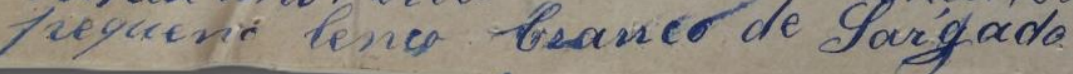


\|1r I Nasceu a $26^{53}$ de Novembro as 3 horas da tarde no hospital de Saõ

Jose emfermaria de Santa Barbara batisado a 28 de Novembro Carlos no hos

5 pital de Saõ Jose Filho de Izabel Maria dos Santos Moradora no Patio de Garcia Numero 5 loja Entrando para a Santa caza da Mesericordia de Lisboa 1 a 7 [borrão]de

10 Dezembro luvando um signal em toda a roupa o Tem uma [borrão] camiza coeiro de beitilha branca fralda uma roupinhas brancas uma vestidinho branco o meio lenço. 1886

15 pequeno lenco branco de Sargado

${ }^{53}$ Número 6 sobreposto ao número 2. 
ESCRITO 18 - AH-SCML - 1890

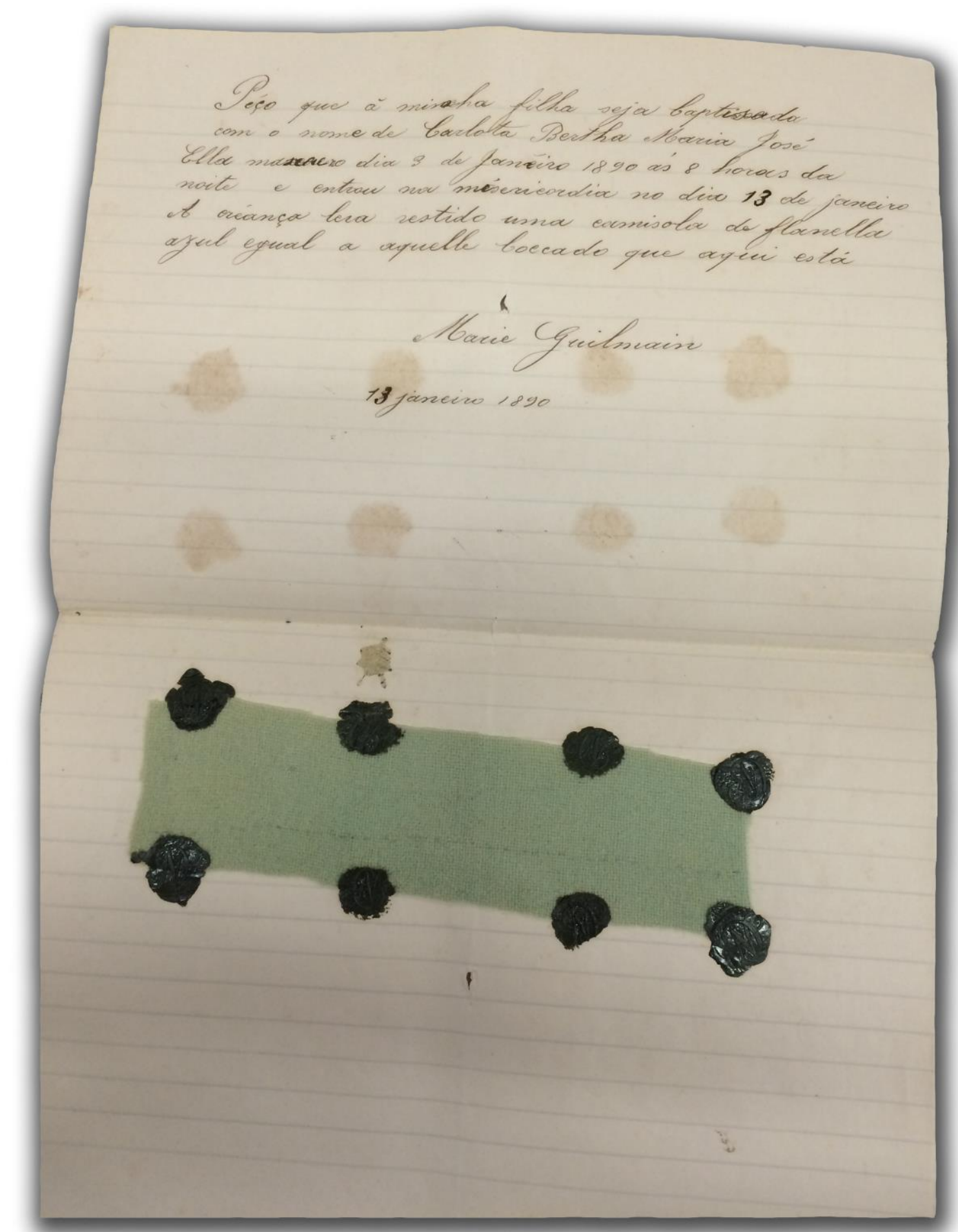


"|1r\| Péço que á minha filha seja baptisada com o nome de Carlota Bertha Maria José

Ella nasceu no dia 3 de Janéiro 1890 ás 8 horas da noite e entrou na misericordia no dia 13 de janeiro

5 A créança leva vestido uma camisola de flanella azul egual a aquelle boccado que aqui está

\section{Marie Guilmain}

13 Janeiro $1890^{54}$

${ }^{54}$ Há um pedaço retangular grande de tecido azul claro colado com gotas de cera 
ESCRITO 19 - AH-SCML - 1892

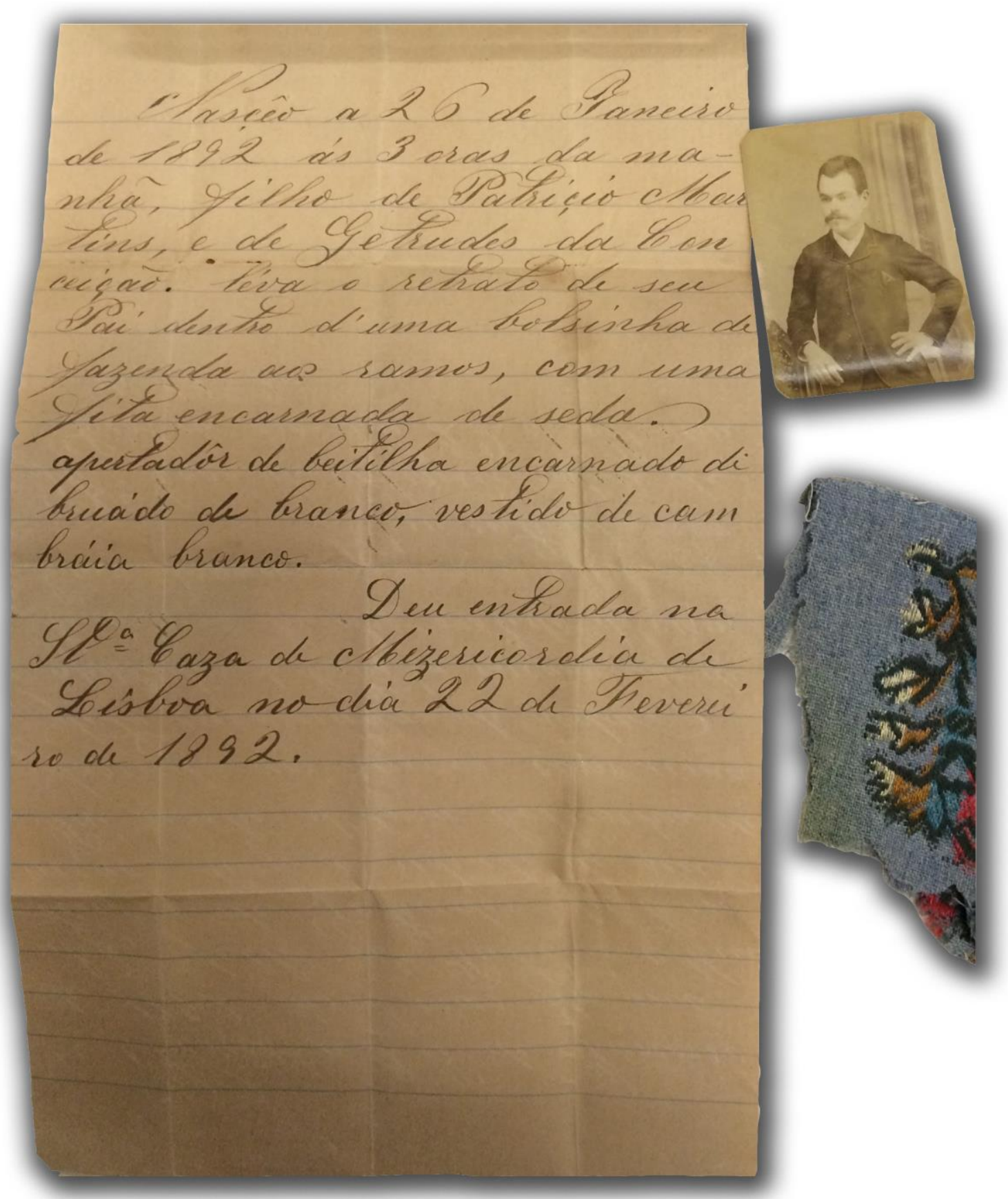


"|1r\| Nascêo a 26 de laneiro de 1892 ás 3 oras da manhã, filho de Patriçio Martins, e de Getrudes da Con

5 ceição. léva o retrato de seu Pai dentro d'uma bolsinha de fazenda aos ramos, com uma fita encarnada de seda. apertadôr de beitilha encarnado di

10 bruádo de branco, vestido de cam bráia branco.

Deu entrada na

Santa Caza de Mizericordia de Lisboa nodia 22 de Feverei

15 ro de $1892 .^{55}$ 
ESCRITO 20 - AH-SCML - 1921

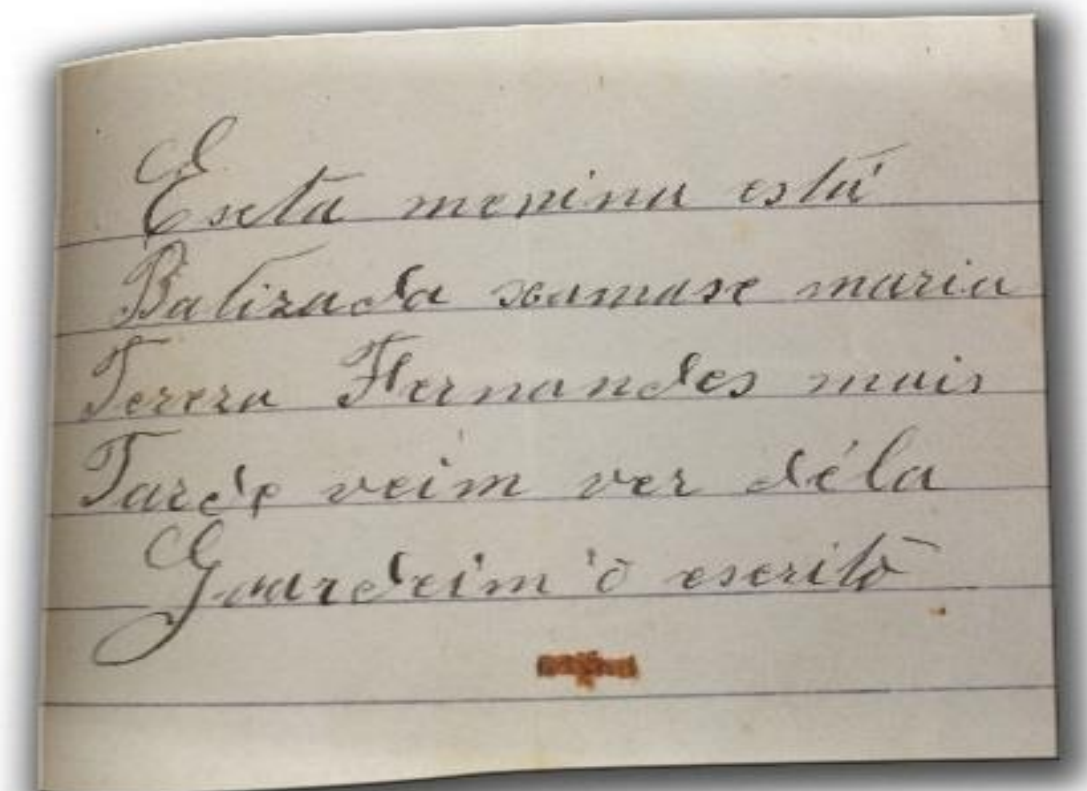


\|1rl| Esta menina está

Batizada xamase maria

Tereza Fernandes mais

Tarde veim ver déla

5 Goardeim o escrito 
128

TRANSCRIÇÃO SEMIDIPLOMÁTICADOS ESCRITOS SELECIONADOS DE SALVADOR

ESCRITO 21 - CMJC-SCMBA - 1959

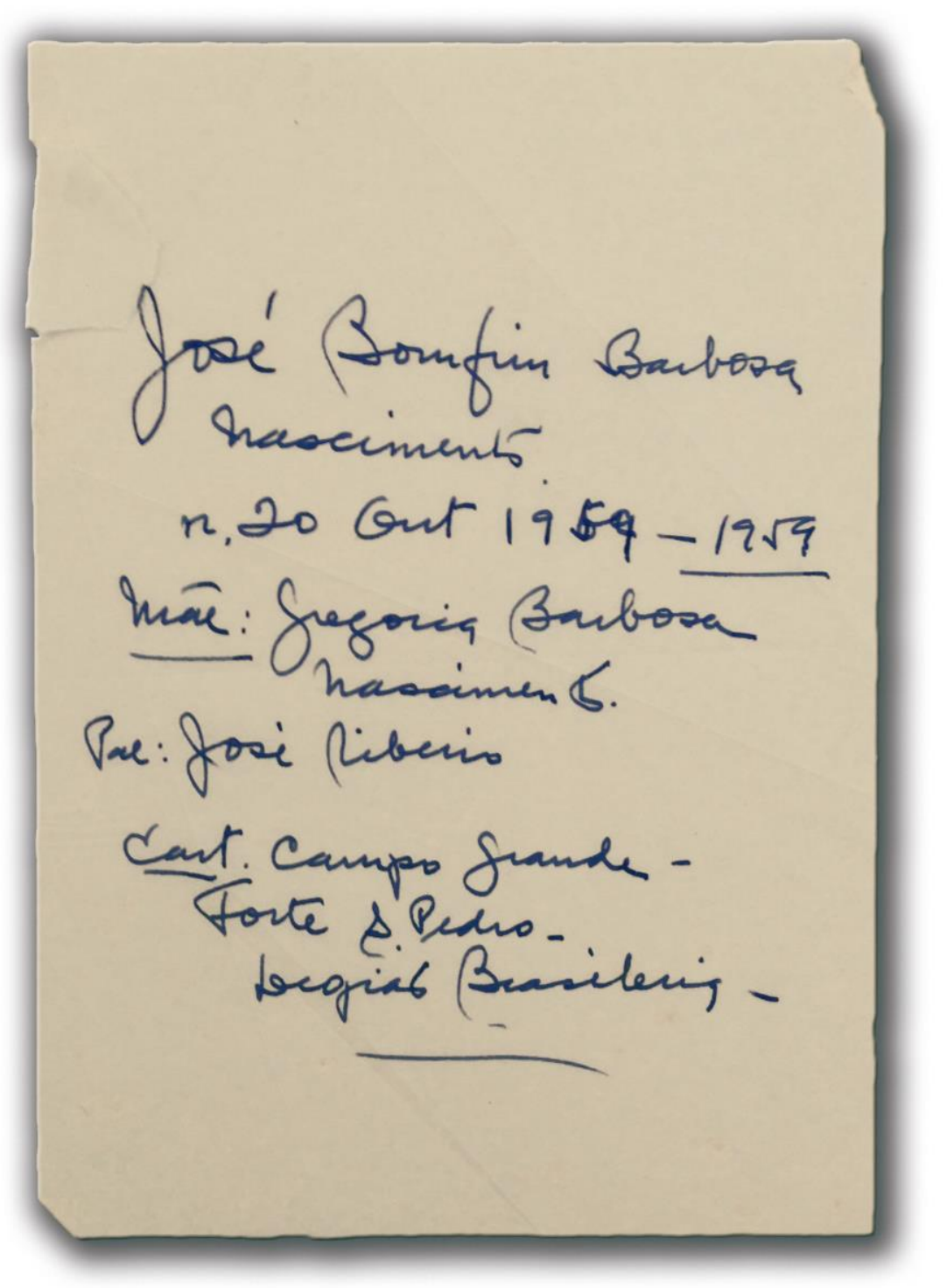


||1r\| José Bomfim Barbosa

Nascimento.

Nascimento 20 Outubro 1959 - 1959

mãe: Gregoria Barbosa

5

nascimento.

Pae: José Ribeiro

cartorio Campo Grande -

Forte Saõ Pedro -

Legião Brasileira - ${ }^{56,57}$

${ }^{56}$ Risco na décima linha

${ }^{57}$ Papel amarelo espresso, liso, semelhante a um papel-cartão 
ESCRITO 22 - CMJC-SCMBA - 1960

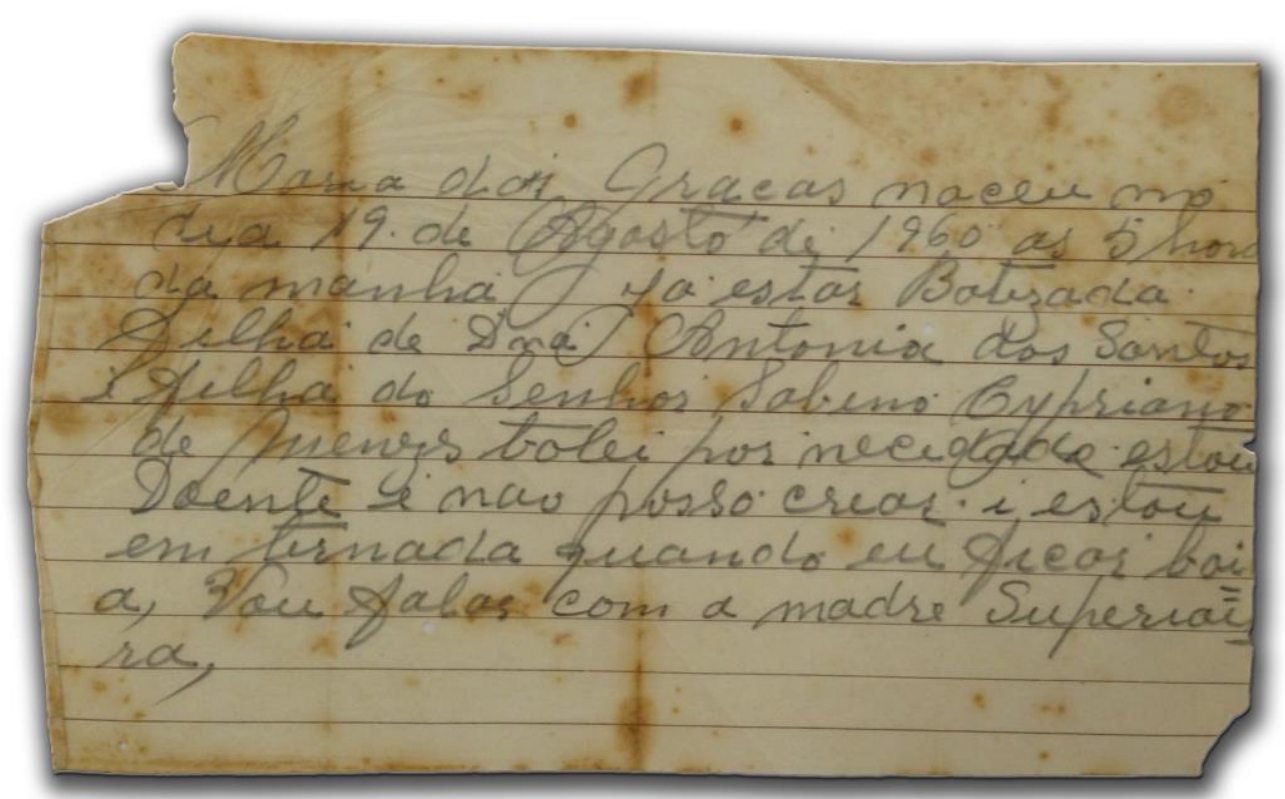


||1r|| Maria das Graças naceu mo dia 19 de Agosto de 1960 as 5 hora[s] da manha Já estar Batizada filha de Dona Antonia dos Santos

5 filha do Senhor Sabino Cypriano de Menezes botei por necedade estou Doente e nao posso crear i estou em ternada quando eu ficar boia, Vou falar com a madre Superioi$10 \mathrm{ra}$, 
ESCRITO 23 - CMJC-SCMBA - 1961

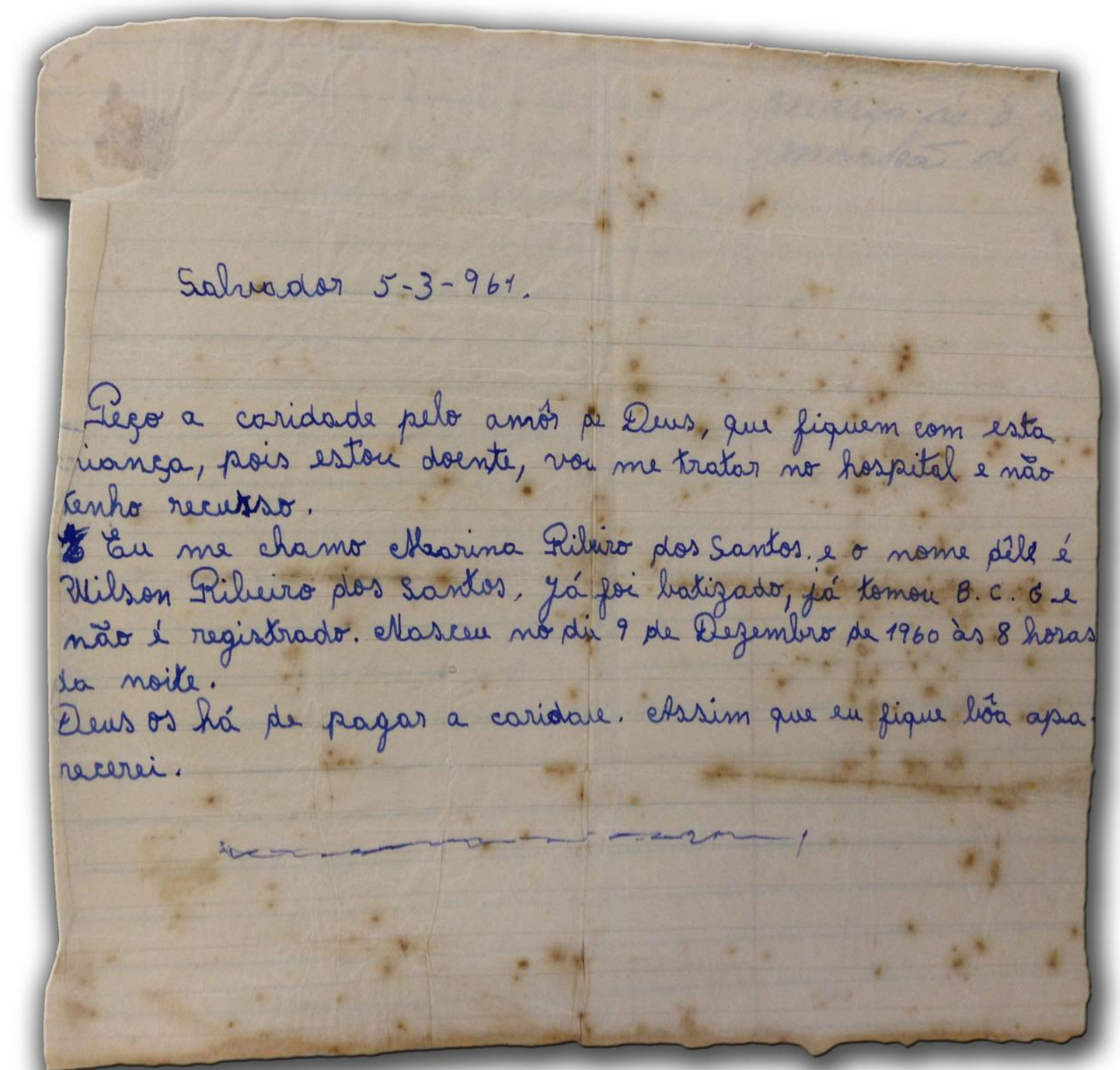


\|1r\| $\quad$ Salvador 5-3-961.

Peço a caridade pelo amôr de Deus, que fiquem com esta criança, pois estou doente, vou me tratar o hospital e não tenho recurso.

5 EE Eu me chamo Marina Ribeiro dos Santos e o nome dêle é Wilson Ribeiro dos Santos, Já foi batizado, já tomou B.C.G. e não é registrado. Nasceu no dia 9 de Dezembro de 1960 às 8 horas da noite.

10

Deus os há de pagar a caridade. Assim que eu fique bôa aparecerei. ${ }^{58}$

58 Traço irregular na décima segunda linha 
ESCRITO 24 - CMJC-SCMBA - 1961

Yoabel bristina Marines Ratirada

Ravaida in "18 de yullo de 1961

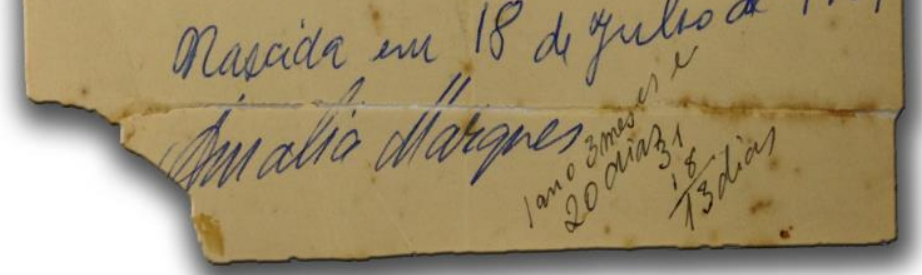


\|1r\| Isabel Cristina Marques

Batisada

Nascida em 18 de Julio de 1961

Amalia Marques

5

$<1$ ano e 3 mezes e

20 dias

31

18

13 dias $>^{59}, 60$

${ }^{59}$ Escrito em diagonal, com outro instrumento de escrita

${ }^{60}$ Papel amarelo espresso, liso, semelhante a um papel-cartão 
136

ESCRITO 25 - CMJC-SCMBA - 1961

Salvados' I de Agosts de 1961" Esta garotinho tem 9 mezés, pelo pai tes uma siturcão finaccira mulnto raca se. Sub metues, elisca a qui ate que ill melhore. Agarâta tem

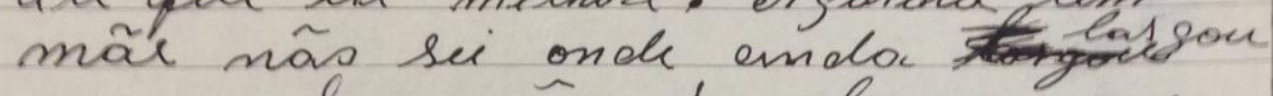
im min ho, mas, se ela quagees timpo, mi a paricer us eamo pai, digo on de ila estoc, para eld vers. eu mesmo como pbi vor zes, fico mueto groto a ismós chifa destoc casager vai toma canta da refirida. A garóto nás ébatisado. mascue em 17 de nowrmbro de 1960 . chama-se bacf ofino. Pai Antônio B.S lwo. ma fondira sifra, pe co que nas di Ininha filka bos en vou besess assim que complete 9 anas, en sou simply operario, esóc estudanto maro en pencás nás poco tamar. cantor, mbis

dí the 30 ménulos 
\|1r\| Salvador' 1 de Agosto de 1961'

Esta garotinho tem 9 mezês, pelo pai ter uma situacão financeira muinto fraca se-submeteces, deixa aqui

5 ate que êle melhore. A garôta tem mãe não sei onde anda largou em minha, mâo, se ela quaquer tempo, mi a paricer eu como pai, digo onde ela esta, para ela ver.

10 eu mesmo como pai vou ver, fico muito grato a irmãs chefa desta casa que vai toma conta da referida. A garôto não é batizado, nasceu em 17 de novembro de 1960 . chama-se

15 Dacj Silva. Pai Antonio B. Silva. mãe Jandira Silva, peço que não dê minha filha pôs eu vou buscar assim que complete 9 anos, eu sou simples operario, e sou estudante

20 moro em pencão não poço tamar conta, mais

<Às 11 e 30 minutos> 61, 62

\footnotetext{
${ }^{61}$ Linha escrita com outro instrumento de escrita, sugere ser uma inserção tardia.

${ }^{62}$ Recortes dentados do papel na parte superior esquerda e na parte direita
} 
ESCRITO 26 - CMJC-SCMBA - 1969

Madre, Boa Tarde

A Sentrora prode entiegar a menima a quem a Senhora achar que tem eredincial paroc reabi-la Conversar, prorque eston superbotado de Servico.

Outietá Viana Een $19 / 12 / 69$ 
\|1r\| Madre,

Boa tarde

A senhora pode entregar a

menina a quem a Senhora achar

5 que tem credencial para recebê-la.

Eu não posso ir aí para

conversar, porque estou superlotada

de serviço -

Julieta Viana

Em 19/12/69 
TRANSCRIÇÃO SEMIDIPLOMÁTICA DOS ESCRITOS SELECIONADOS DO RIO DE JANEIRO

ESCRITO 27 - ERD-SCMRJ - 1858

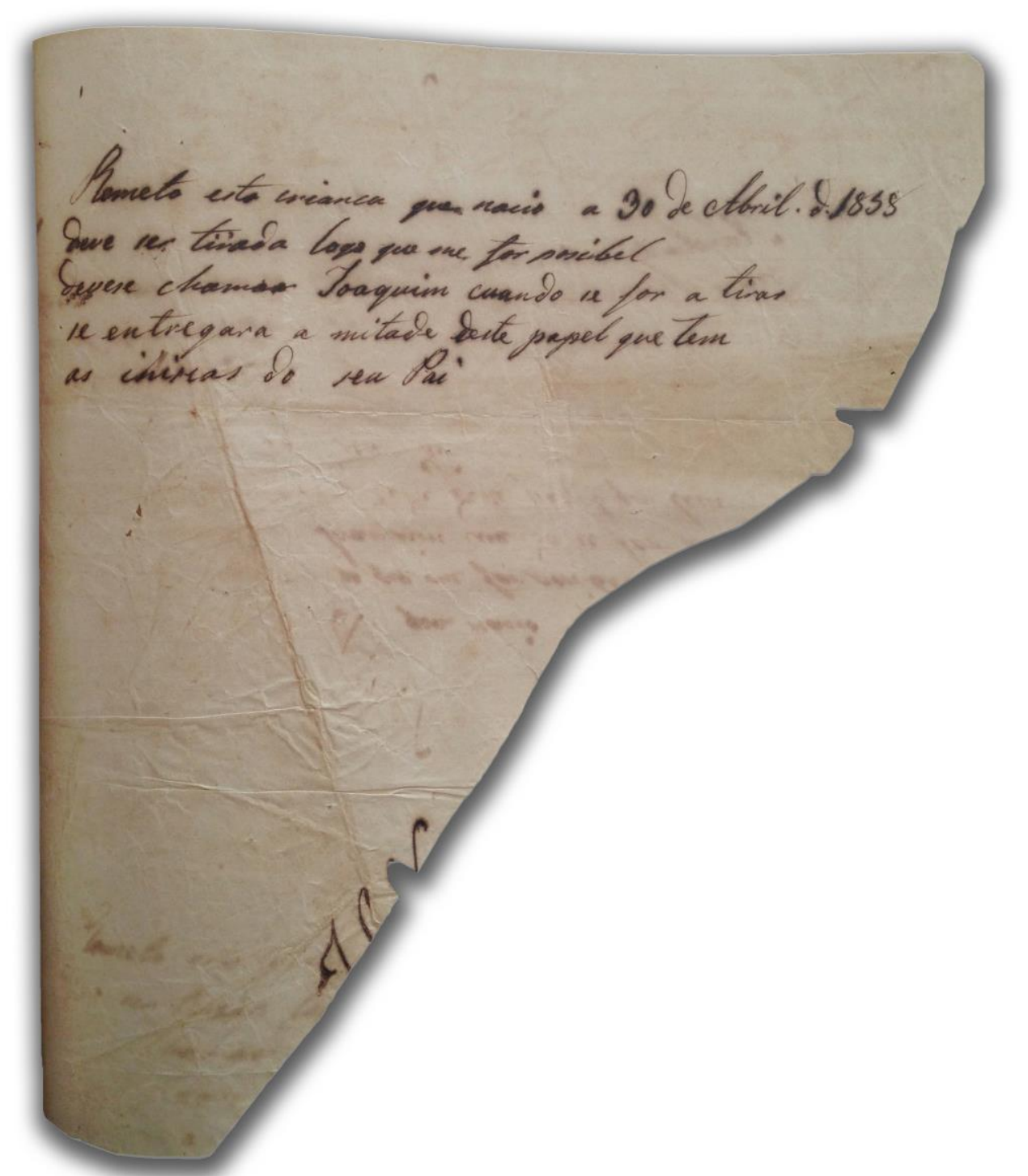


\|1r\| Remeto esta crianca que nacio a 30 de Abril . de1858 deve ser tirada logo que me for possibel

devese chamar loaquim cuando se for a tirar

$5 \quad$ as inisias do seu Pai

$\underline{\mathrm{JLN}}^{63,64}$

\footnotetext{
${ }^{63}$ Iniciais JLN cortadas ao meio

${ }^{64}$ Suporte em formato triangular e recorte oblíquo em um dos lados
} 
ESCRITO 28 - ERD-SCMRJ - 1858

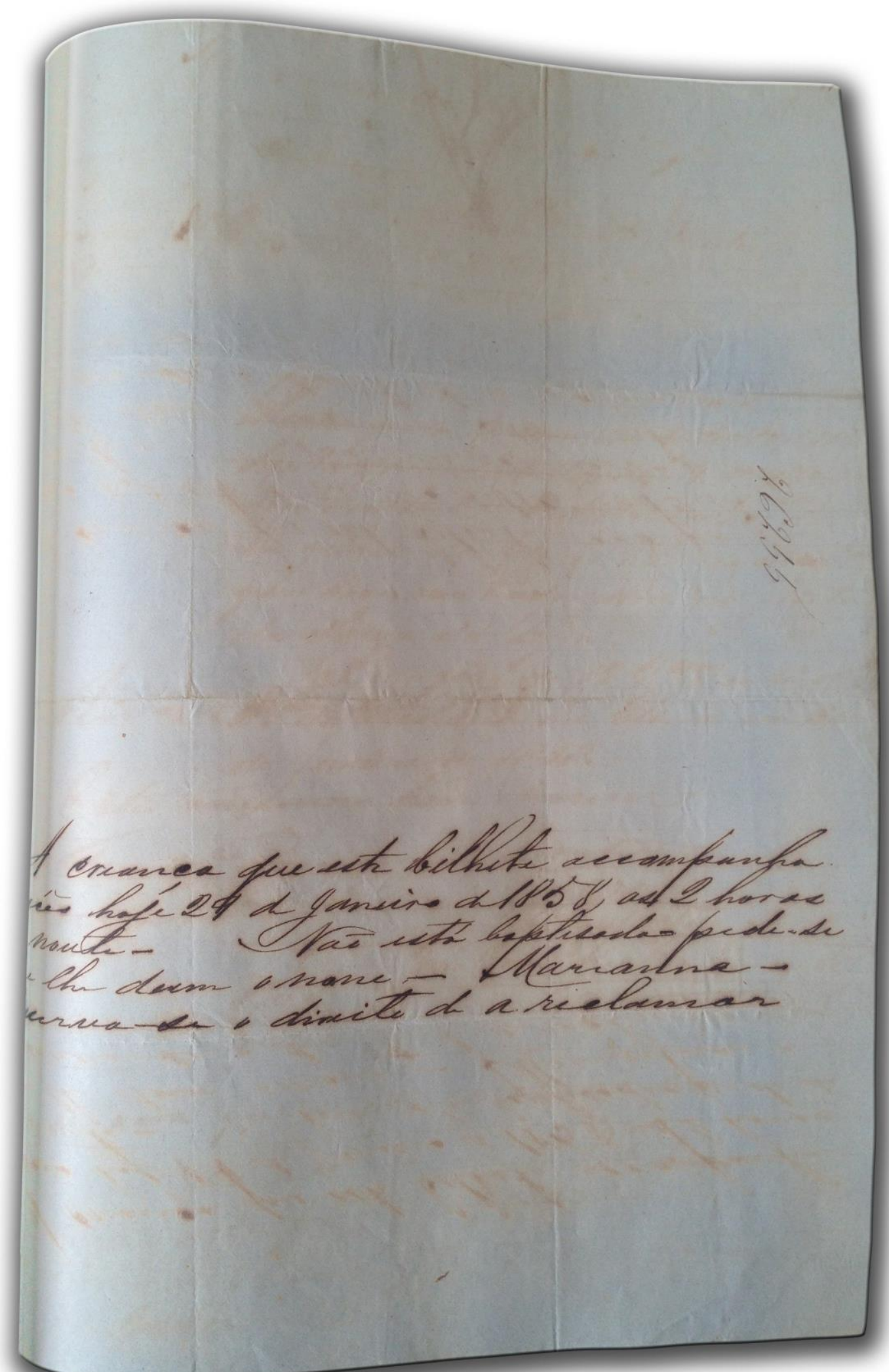


\|1r\| A criança que este bilhete accompanha [nas]cêo hoje 29 de Janeiro de1858, as 2 horas [da] noute - [espaço] Não está baptisada pede-se [que] lhe deem o nome - Marianna -

5 [c]urva-se o direito de a reclamar ${ }^{65}$ 
ESCRITO 29 - ERD-SCMRJ - 1858

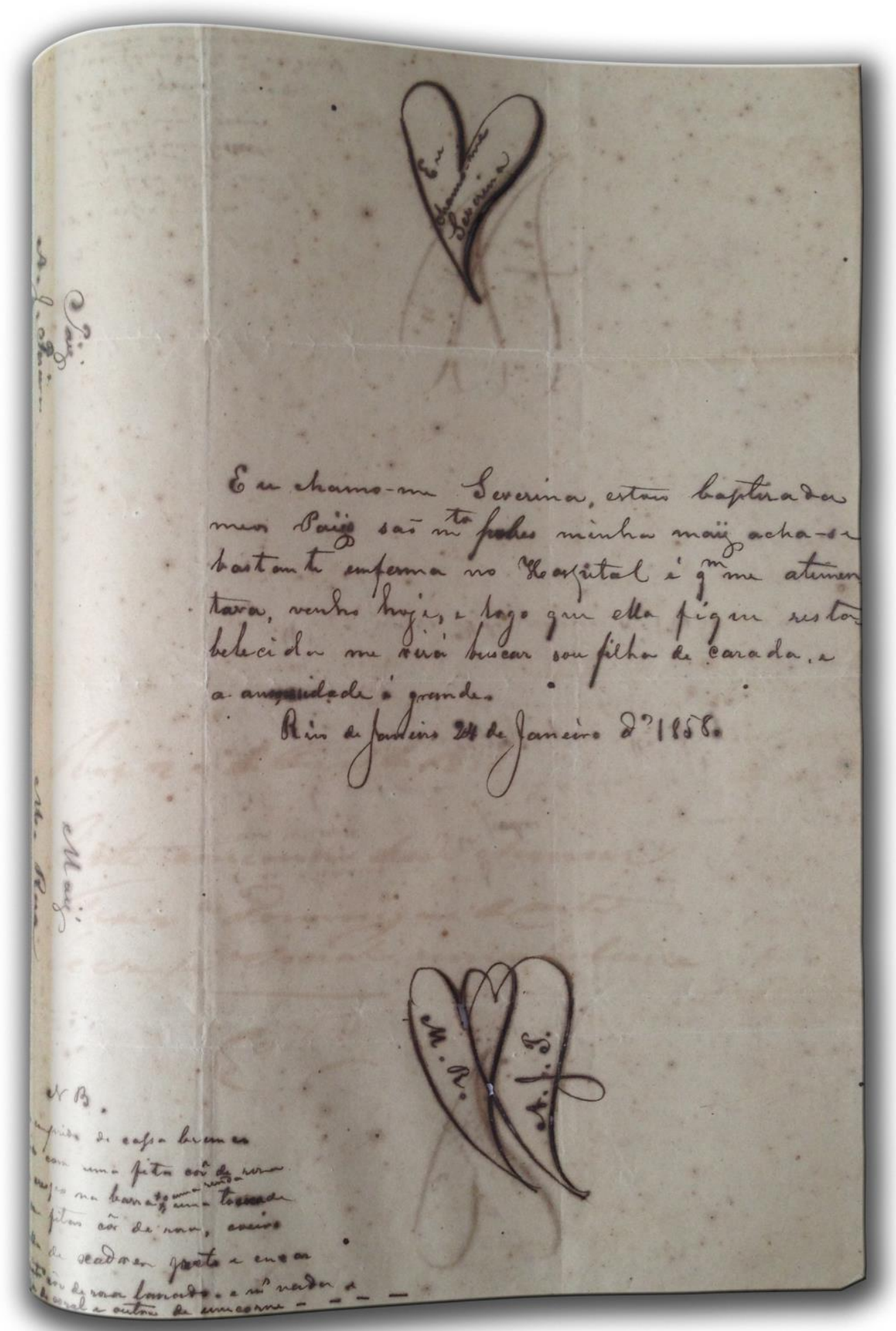


\|1r\| Eu chamo-me Severina, est[ou] baptisada meos Pais são muito pobres minha maÿ acha-se bastante emferma no Hospital é quem me atimen tava, venho hoje, e logo que ela fique resta-

5 belecida me virá buscar sou filha de casada, e a anecessidade é grande.

Rio de laneiro 24 de laneiro de 1858 66, 67

${ }^{66}$ Desenho de um coração com os escritos: Eu| chamo-me| Severina e iniciais M. R. / A. J. P. escritas dentro de um coração duplo

${ }^{67}$ Anotações na margem esquerda inferior 
ESCRITO 30 - ERD-SCMRJ - 1858

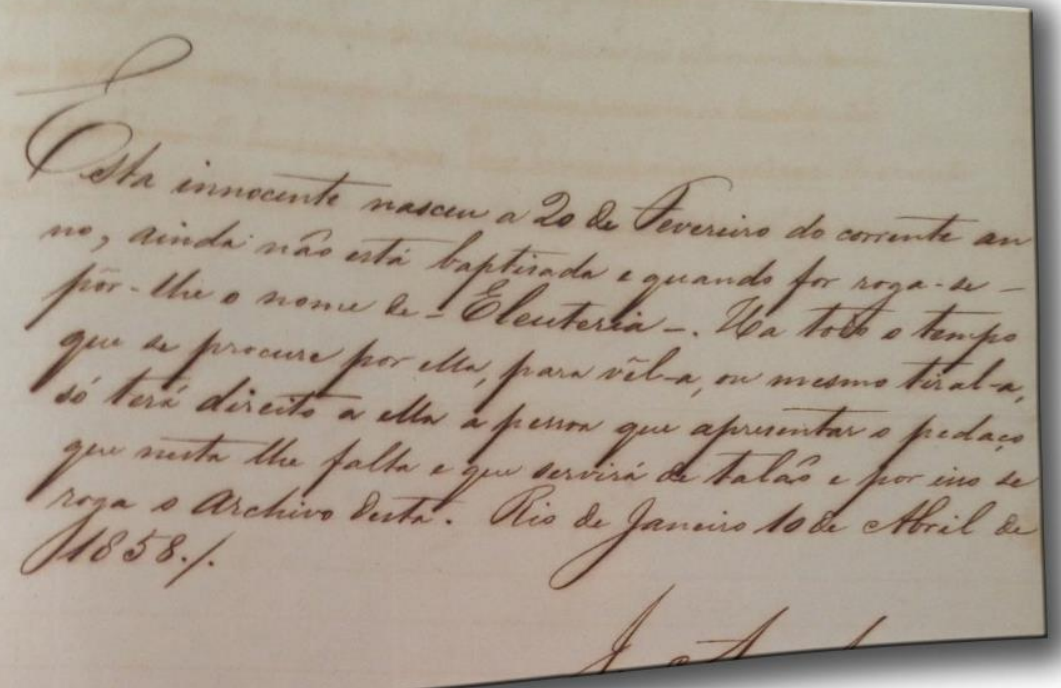


Esta innocente nasceu a 20 de Fevereiro do corrente an no, ainda não está baptisada e quando for roga-se pôr-lhe o nome de - Eleuteria - Ha todo o tempo que se procure por ella, para vêl-a, ou mesmo tiral-a, 5 só terá direito a ella a pessoa que apresentar o pedaço que nesta lhe falta e que servirá de talaõ e por isso se roga o Archivo desta. Rio de Janeiro 10 de Abril de 1858./.

$$
\underline{\mathrm{JAA}}^{68}
$$

${ }^{68}$ Recorte grande em forma de triângulo na parte direita do papel, que corta as iniciais JAA ao meio 
ESCRITO 31 - ERD-SCMRJ - 1858

munino evta baptuado con o nonue de Clias: hojo tem 23 dias

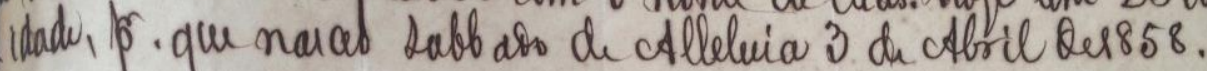

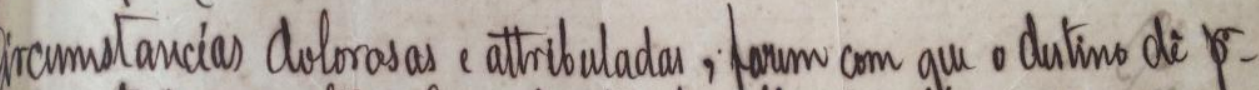
lai a eite innocente, a Cara sauta du cllesiricordin, ese onus ono Who for mais venterroso um dia, elle tera redamato à $\mathrm{ma}$ lai adptiva.

Plio de Gamino, olo de abiel dess88. 
[Es]te menino está baptisado com o nome de Elias: hoje tem 23 dias [de] idade, por que nasceo sabbado de Alleluia 3 de Abril de 1858.

Circunstancias dolorosas e attribuladas, fazem com que o destino dê por Mãi este innocente a Casa Santa da Mesericordia, e se o mesmo

5 destino for mais venturoso um dia, elle será reclamado àSua Mai adoptiva.

Rio de Janeiro, 26 de abril de1858. 
ESCRITO 32 - ERD-SCMRJ - 1858

Ylamo genkor.

Yyai Vica de poxilado cote angenteo Heu Hoene devejor Centorséce Rogarce a caridade dotem lralar "I nav hajia inigano pois devern hir buscar wh peushor de lanto valor - a mizade, e se hade reconjuncar ludo og for jercino, roga ce de novo a caridade dobom lrata mento cno. ungano g̈nossa ver leva ula lila nara deviralihoje de maiode Iica encaha dosespusto e) le anyo.e Ycos operteja;. nobrascinho leva durta mesena Yila 
16628

||1r||

Illustrissimo Sẽnhor

Aqui fica depositado este anyinho Seu Nome deve ser Antonio Roga-çe a caridade do bem tratar

5 e que não haja ingano pois devem hir buscar este penhor de tanto valor e a mizade, e se ha de reconpençar tudo o que for perçizo, roga-ce de novo a caridade do bom tratamento e no

10 engano que possa ver leva esta fita para de viza; hoje <espaço> de Maio de 1858.

Fica en caza dos Esposto

Este anyo e Deos o porteja;

no brasçinho leva desta mesma fita 
ESCRITO 33 - ERD-SCMRJ - 1858

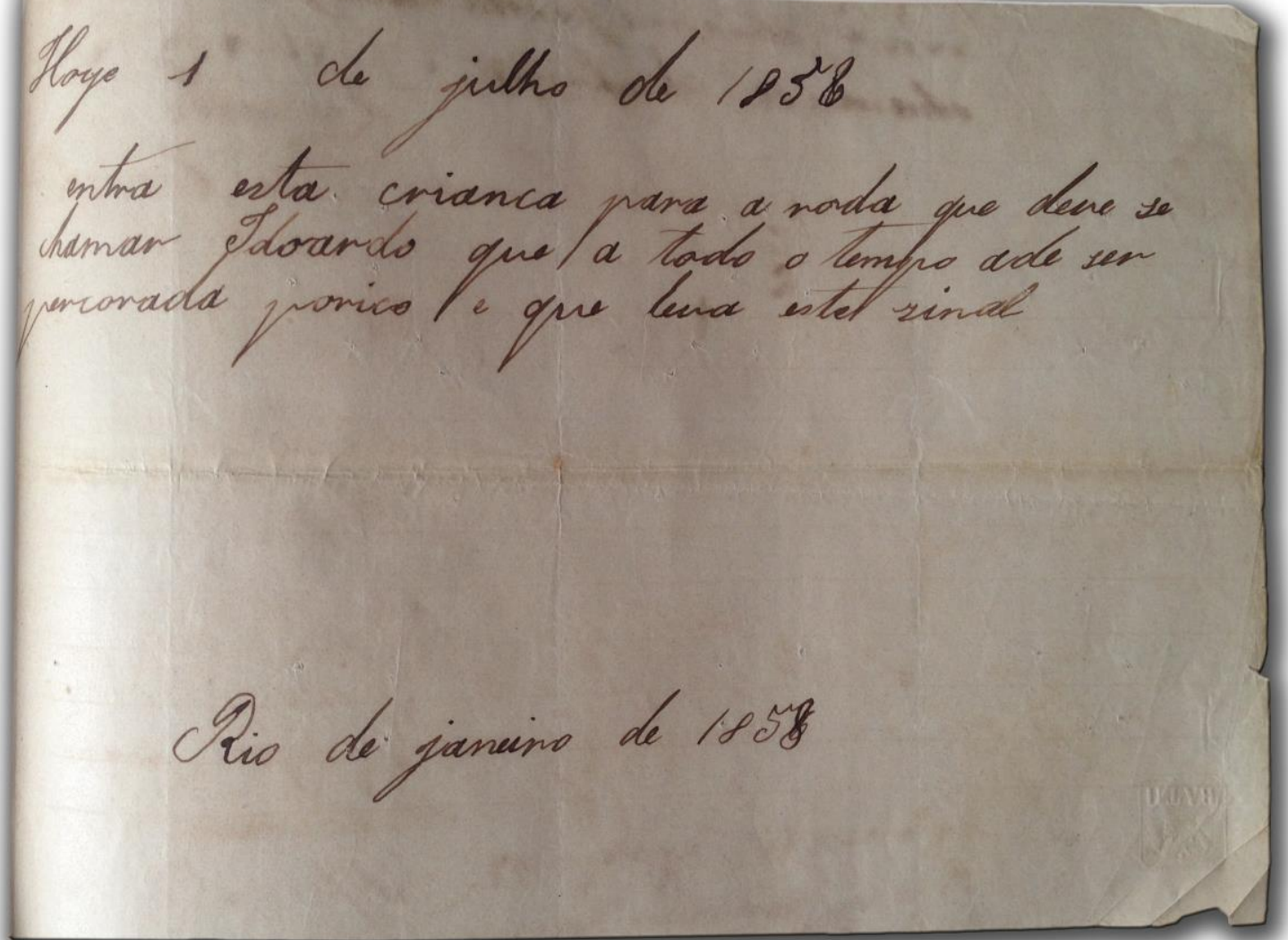


\|1r\| $\quad$ Hoje 1 de julho de 1858

entra esta crianca para a roda que deve se chamar Idoardo que a todo o tempo ade ser percorada porico e que leva este sinal 
ESCRITO 34 - ERD-SCMRJ - 1858

6

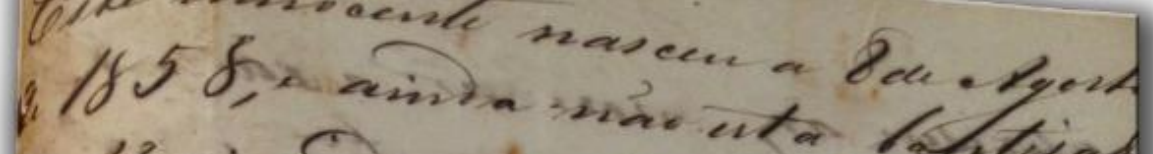

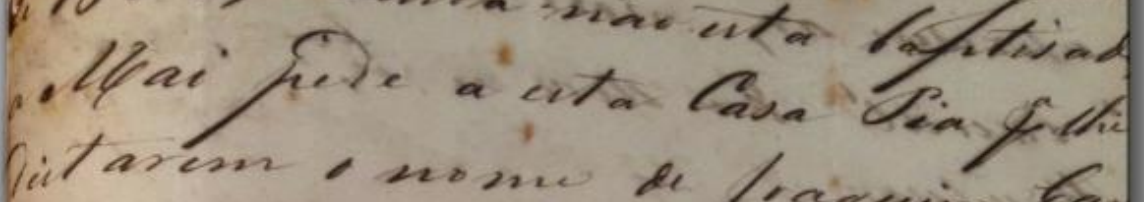

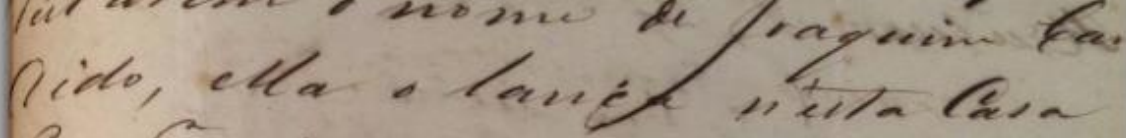
iaif leax meivesea,e frella de tidy a recesdes, pele a Cauta

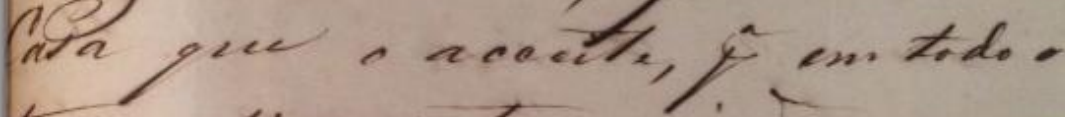

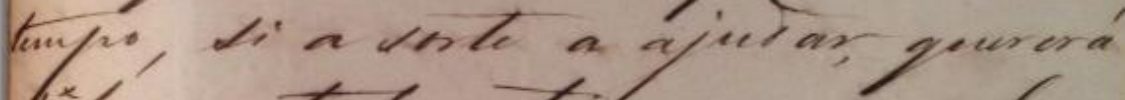
hel o,e tatey tobmar a seceter

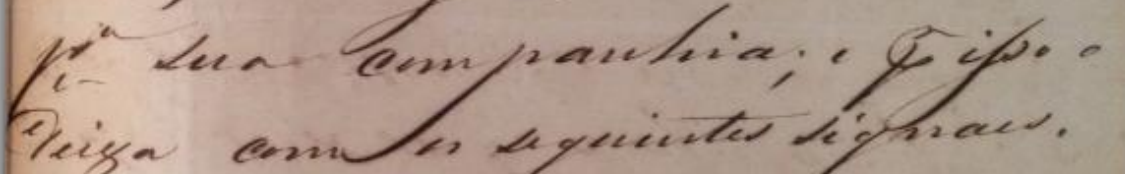

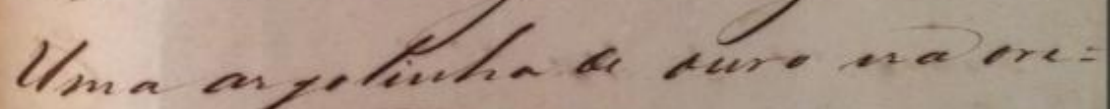
tha Nelextax.

Hue levieteire de chita on de calé. an flowe bamea meived.

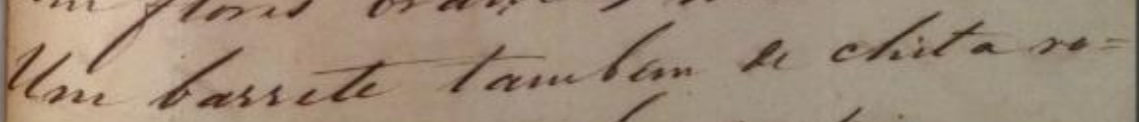

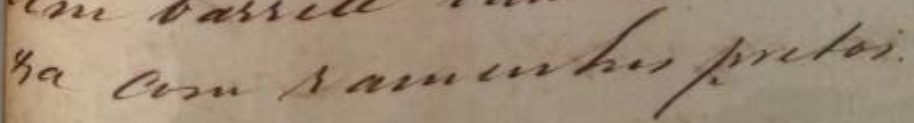


||1r| Este innocente nasceu a 8 de Agosto de 1858, e ainda não está baptizad[o] a Mai pede a esta Casa Pia para Ihe [acc]eitarem o nome de Joaquim Can-

5 [D]ido, ella o lanca n'esta Casa

Pia por Sua miseria, e falta de todoz os recursos, pede a Santa Casa que a acceite, para em todo o tempo, si a sorte a ajudar, quererá

10 vêl-o, e talvez tornar a receber para sua companhia; e por isso o deixa com os seguintes signaes. Uma argolinha de ouro na ore= Iha esquerda.

15 um sinteiro de chita côr de café. com flores brancas miúdas.

Um barrete tambem de chita ro= xa com raminhos pretos. 
ESCRITO 35 - ERD-SCMRJ - 1858

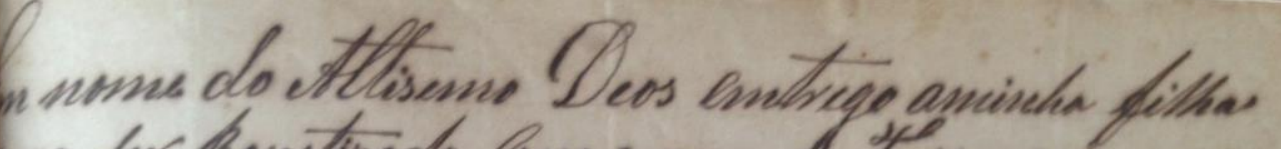
no dia. 18 de otgosts as g horas da manhas operi us is me achartlone piosey yeara a criar entioges que timay que ella Seja vosa dithas fa cosn es to sinal maids huma maht a que liva enér ruthada fiça. bume jeedaco infi proceurar

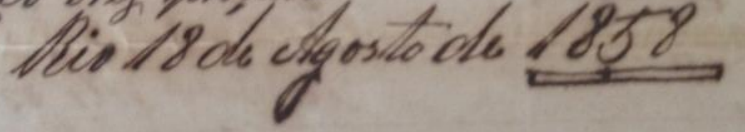

A. B. 
||1r|| Em nome do Altisemo Deos emtrego aminha filha para ser Baptizada Com onome de Tereza que naçeu no dia 18 de Agosto as 9 horas da manha e por eu naõ me açhar Com poses para a çriar emtregoa que

5 estimaej que ella Seja vosa filha e com este sinal e mais huma manta que leva embrulhada fiça hum pedaço irej proçurar

Rio 18 de Agosto de $\underline{\underline{1858}}$

\section{A.B.L.}


ESCRITO 36 - ERD-SCMRJ - 1858

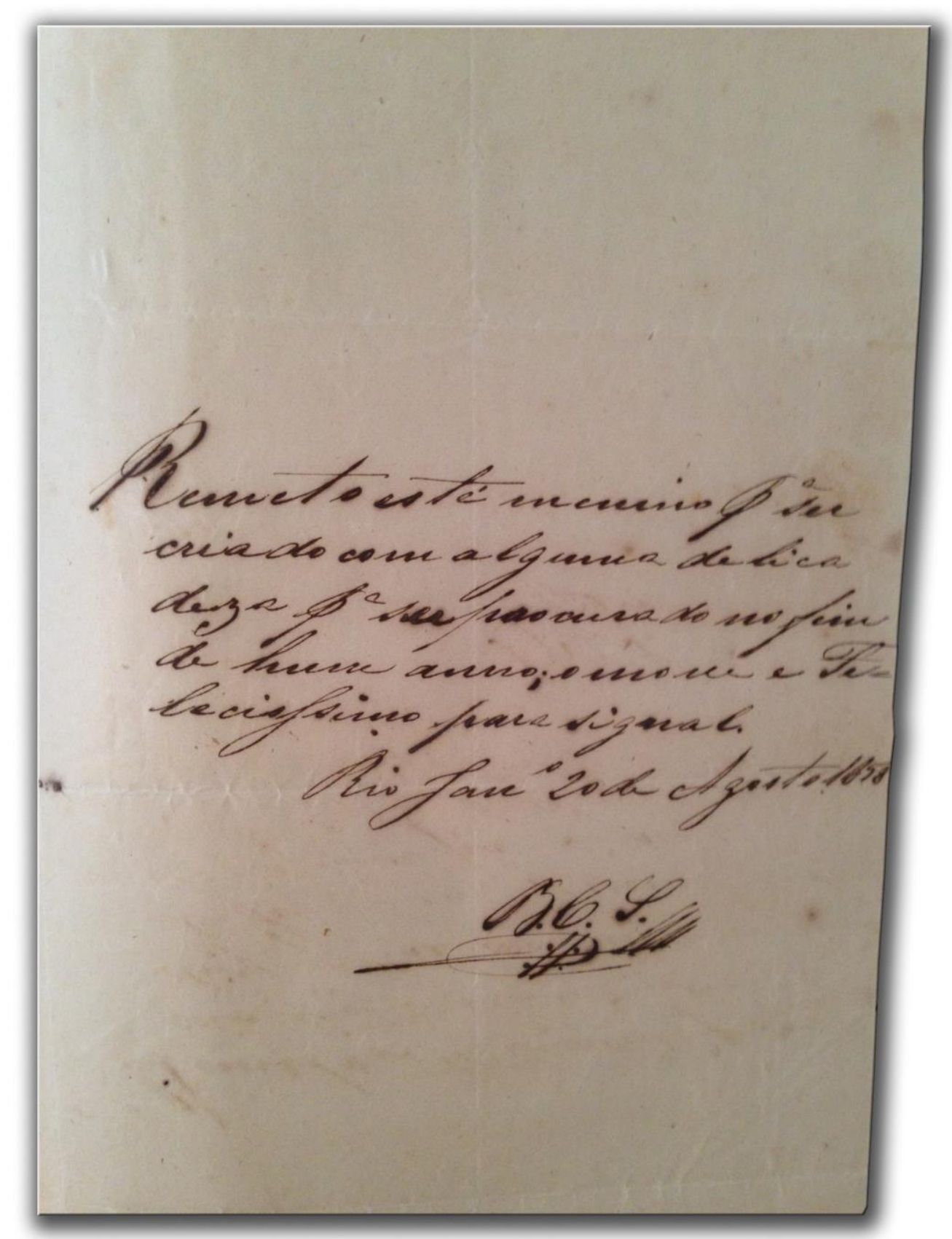


\|1r\| Remeto esté menino para ser criado com alguma delica deza para ser procurado no fim de hum anno; o nome e Fe-

5 lecisssimo para signal

Rio Janeiro 20 de Agosto de 1858

B.C.S. 
ESCRITO 37 - ERD-SCMRJ - 1858

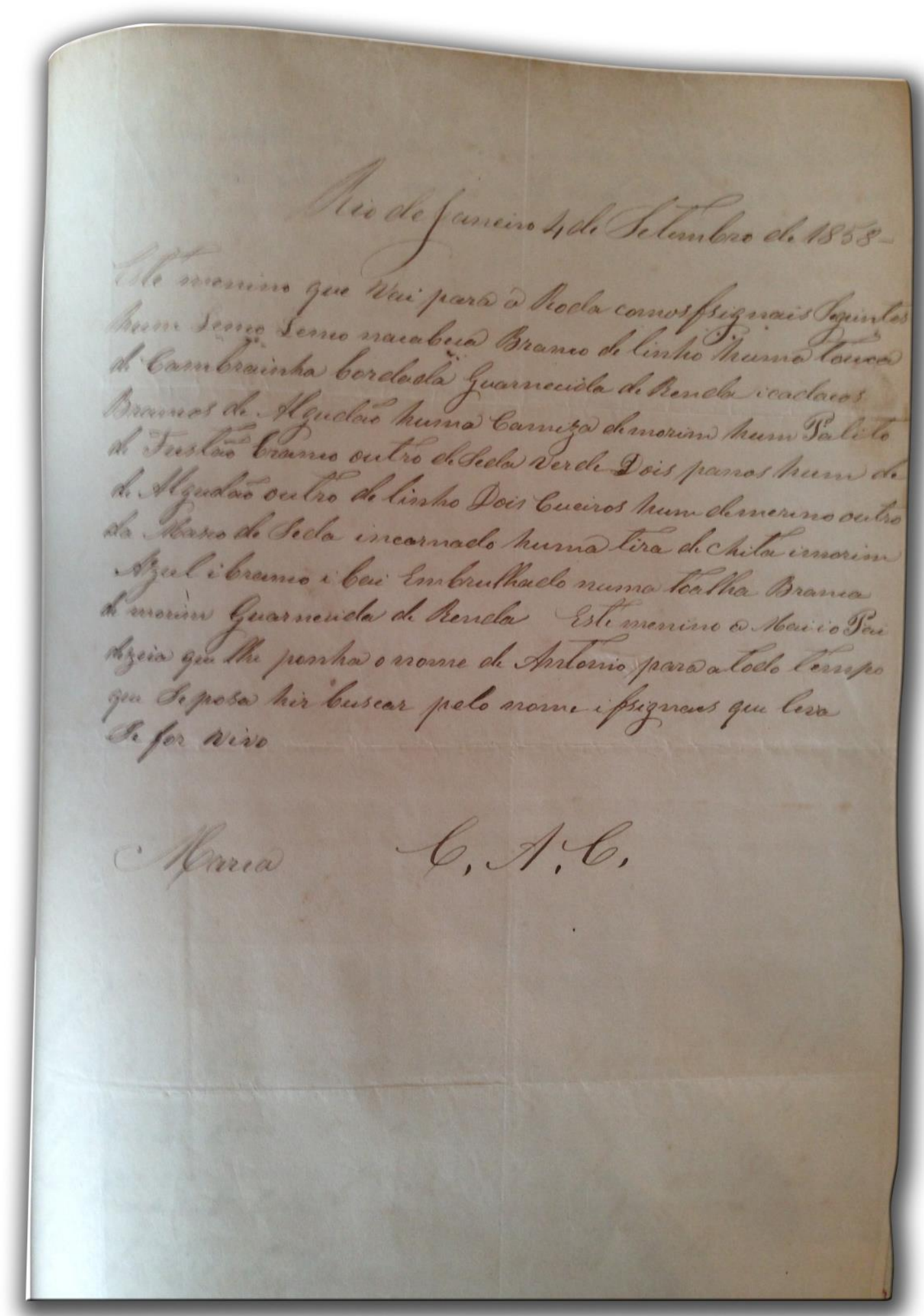


\|1r\| $\quad$ Rio de Janeiro 4 de Setembro de 1858 -

Este menino que vai para a roda comosssignais Seguintes hum Lenco [[Lenco]] nacabeça Branco de linho huma touca di Cambrainha bordada Guarnecida de Renda icadacos

5 Brancos de Algudão numa Camiza de morim num Palito di Feestaõ branco outro de Seda Verde Dois panos hum de de Algudaõ outro de linho Dois Cueiros num demerino outro do Masio de Seda incarnado huma tira de chita emmorim Azul i branco i Ceu Embrulhado numa toalha Branca

10 de morim Guarnecida de Renda [espaço] Este menino a Mae e o Pai dezeia que lhe punha o nome de Antonio para atodo tempo que Seposa hir buscar pelo nome iSignaes que leva Se for Vivo

Maria <espaço> C.A.C. 
ESCRITO 38 - ERD-SCMRJ - 1858

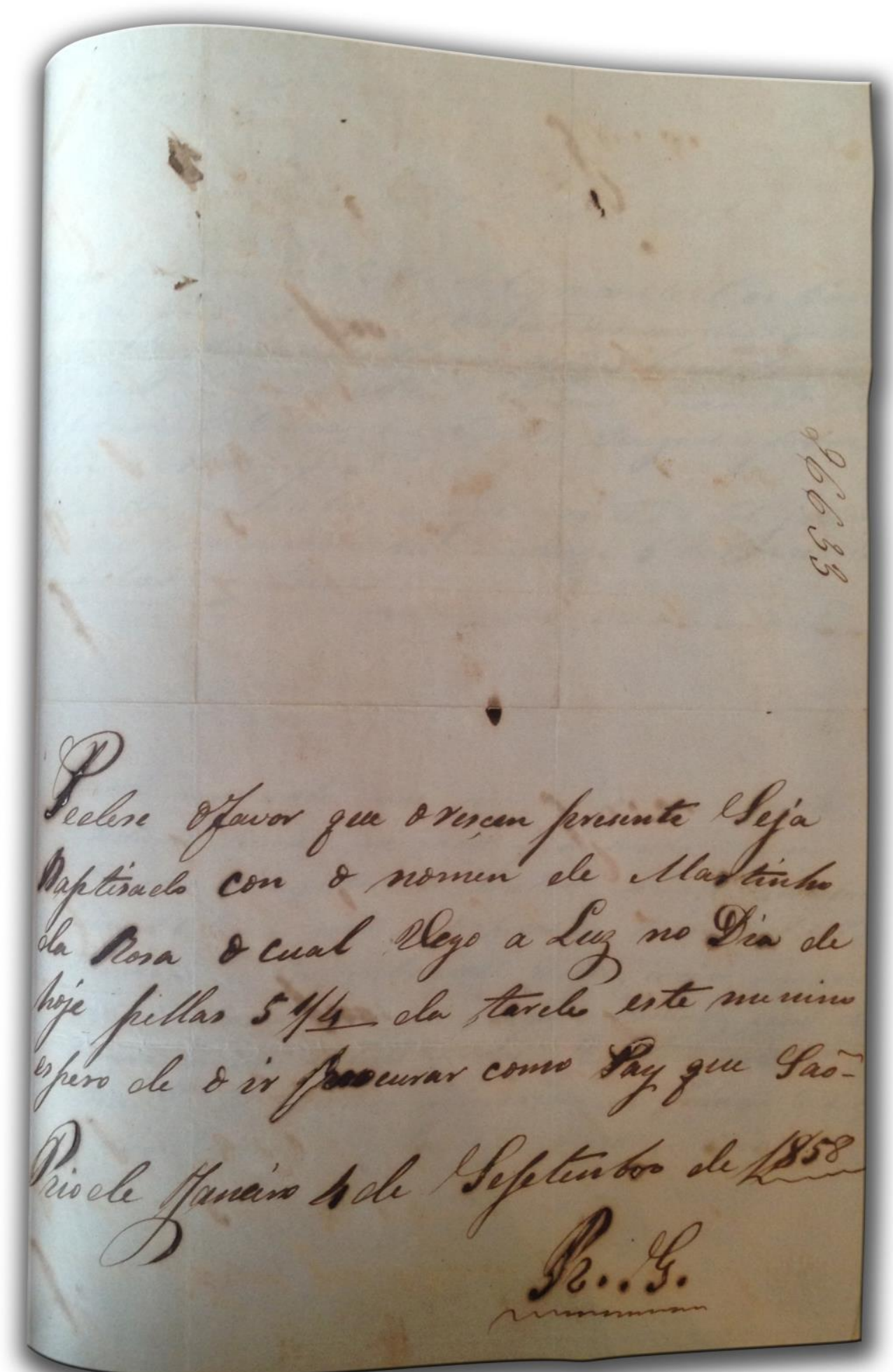


\|1r\| Pedese ofavor que o resçen presente Seja Baptisado con o nomen de Martinho da Rosa o cual llego a Luz no Dia de hoje pellas $5^{1 /} \underline{4}$ da tarde este menino espero de $o$ ir procurar como Pay que Saõ5 Rio de Janeiro 4 de Septembro de $\underline{1858}$ R...G. 
164

ESCRITO 39 - ERD-SCMRJ - 1858

- onveroras motiros, obrigas a abar. donar esta menina, (Dens sabe atéquando...

Pede-sc para que exta se chame Yoabel, a que the converven dempre ao pespoes a medachor que leva, dentro da qual existe o signal $a_{0}$ dew reconhecimento, quarido fon re elarnada; eque a fressow que a re clamas a presutará uma car. ta diegual theor destor. Origando-nos $(200$ toda a despera que ti. wer felito in dua eriaca. (De vessor cacitate vos coracoesem nome aw (Dens, to oura es perác esta es molo: do que o compess a qrato - Zaco evans: aw 1838 -

16. . dow

Narecur ono If d'Agosto, mas he baptisada 
||1r|| ${ }^{69}$ Ponderozos motivos, obrigão a abandonar esta menina, Deus sabe até quando...

Pede-se para que esta se chame

5 Isabel, e que the conservem sempre ao pesçoço a medalha que leva, dentro da qual existe o signal do seu reconhecimento, quando fôr reclamada; e que a pessoa que

10 a reclamar apresentará uma carta d'egual theor desta. Obrigando-nos por toda a despera que ti= ver feito em sua criaçaõ.

De vossos caritativos coraçoẽs e em

15 nome de Deus, se ouza esperar esta esmola; do que se confessa grato

- 2 de Novembro de 1858 - M. J. da S.P. Nasceu em 17 deAgosto, não he baptisada

\footnotetext{
${ }^{69}$ Há um tipo de filigrana em alto relevo com as letras MAU inseridas em um brasão
} 
ESCRITO 40 - ERD-SCMRJ - 1858

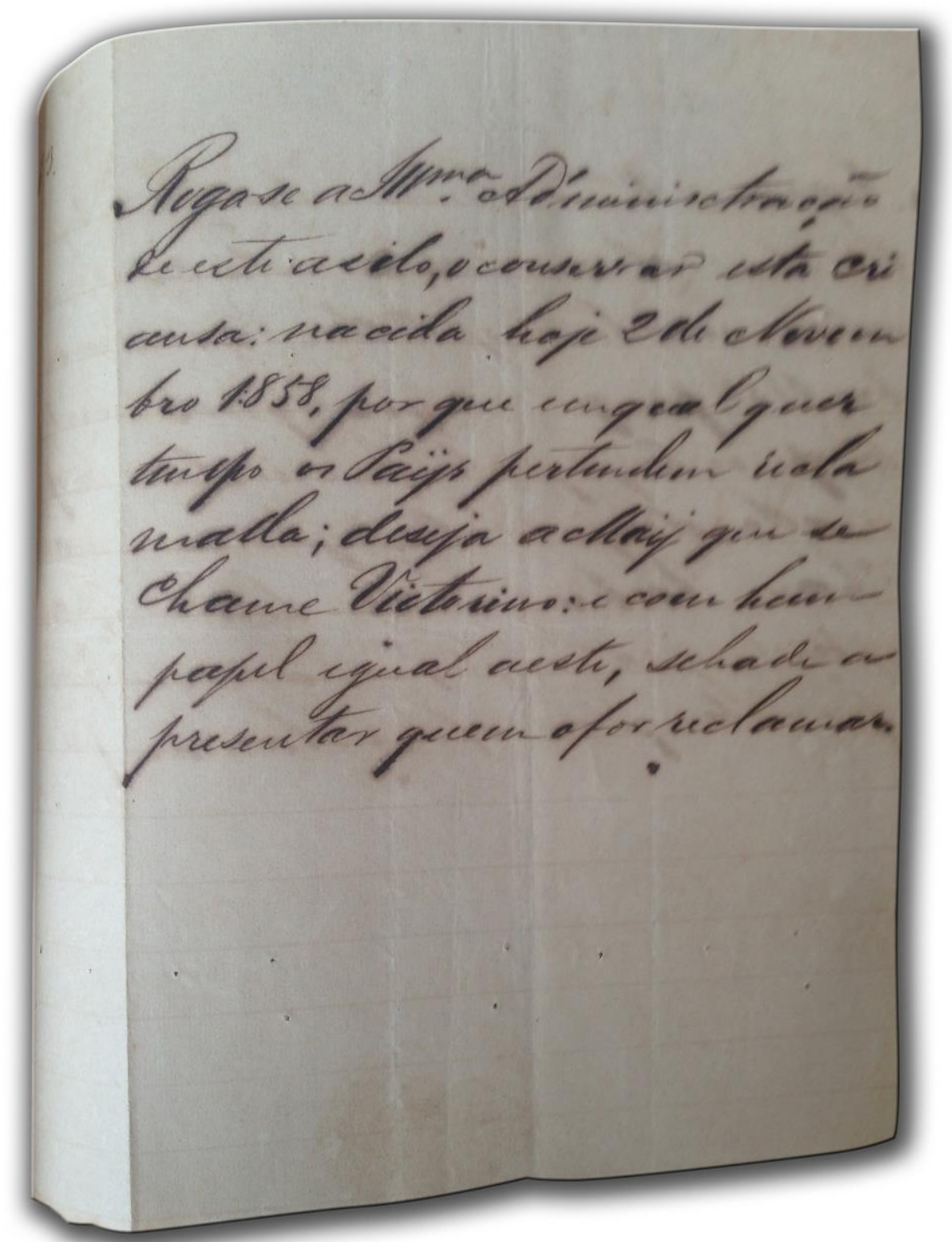


||1r\| Roga-se a Illustrissima Ad'ministração de este asilo, o conservar esta cri ansa: nacida hoje 2 de Novem bro 1858, por que em qualquer

5 tempo os Paÿs pertendem recla malla; deseja a Maÿ que se chame Victorino: e com humpapel igual aeste, sehade a presentar quem ofor reclamar. 
ESCRITO 41 - ERD-SCMRJ - 1858

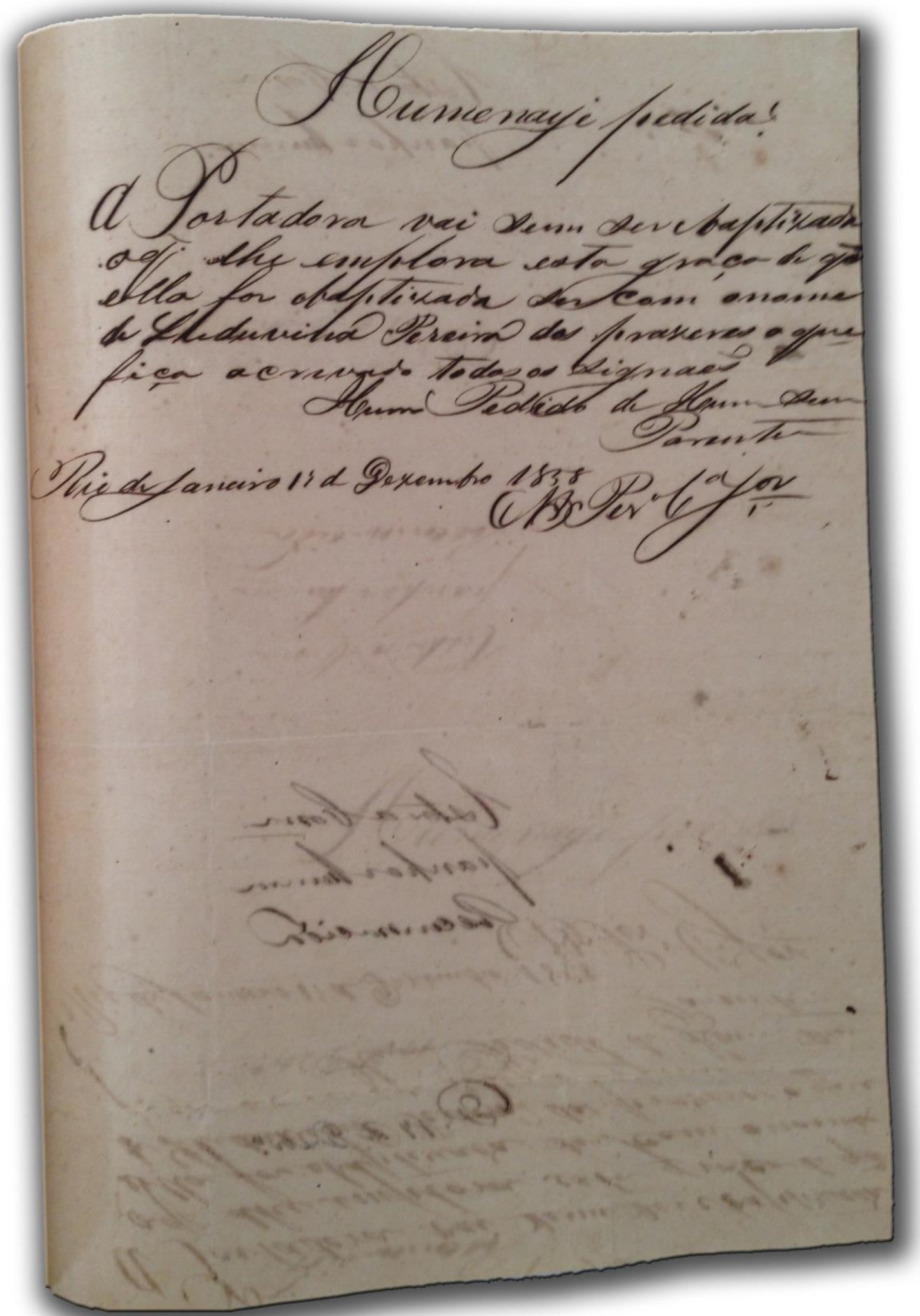


\|1r\| Humenaije pedida!

A Portadora vai sem ser baptizada oque lhe emplora esta graça de que ella for obaptizada ser com onome

5 de Luduvina Pereira dos prazeres o que fica acrivado todos os signaes Hum Pedido de Hum sem Parente Rio de Janeiro 17 de Dezembro 1858 Antonio Pereira Costa Santos 
ESCRITO 42 - ERD-SCMRJ - 1858

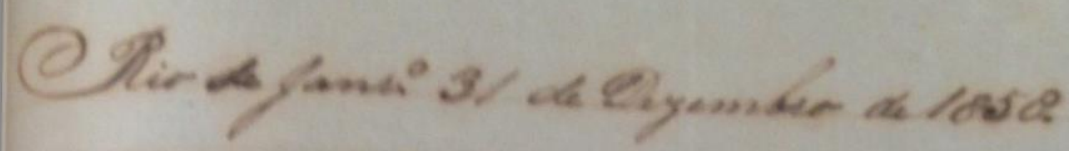

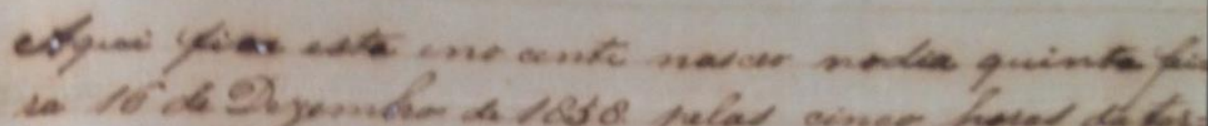

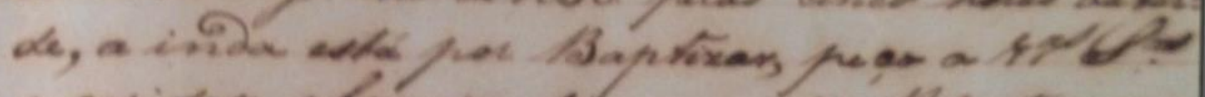

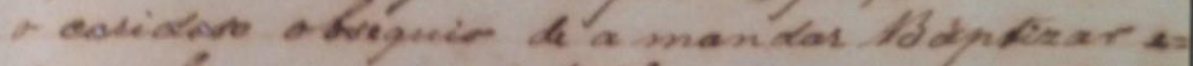

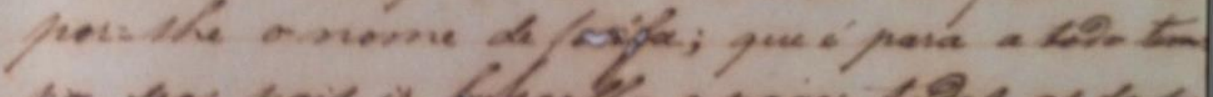

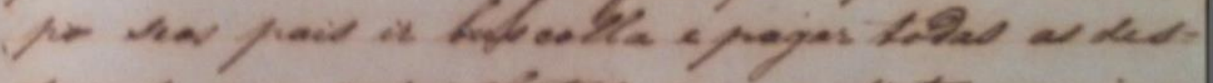

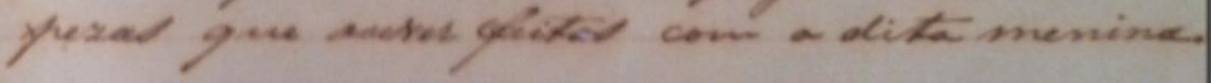

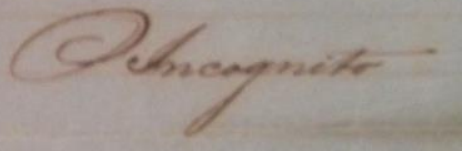

$\overrightarrow{1}$

18

I

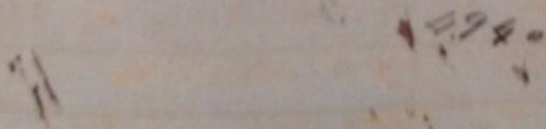


"|1r\| Rio de Janeiro 31 de Dezembro de $1858 .{ }^{70}$

Aqui fica esta ino cente nasceu nodia quinta fei ra 16 de Dezembro de 1858 pelas cinco horas da tar= de, a inda está por Baptizar, peço a Vossas Senhorias

5 o caridoso obsequio de a mandar Baptizar e= por-lhe o nome de Joséfa; que é para a todo tem= po seus pais ir buscalla e pagar todas as des= pezas que ouver feitas com a dita menina.

\section{$\underline{\text { O Incognito }}$}

$$
<494>^{71}
$$

\footnotetext{
${ }^{70}$ Recorte no canto direito superior

${ }^{71}$ Anotação tardia
} 
ESCRITO 43 - ERD-SCMRJ - 1880

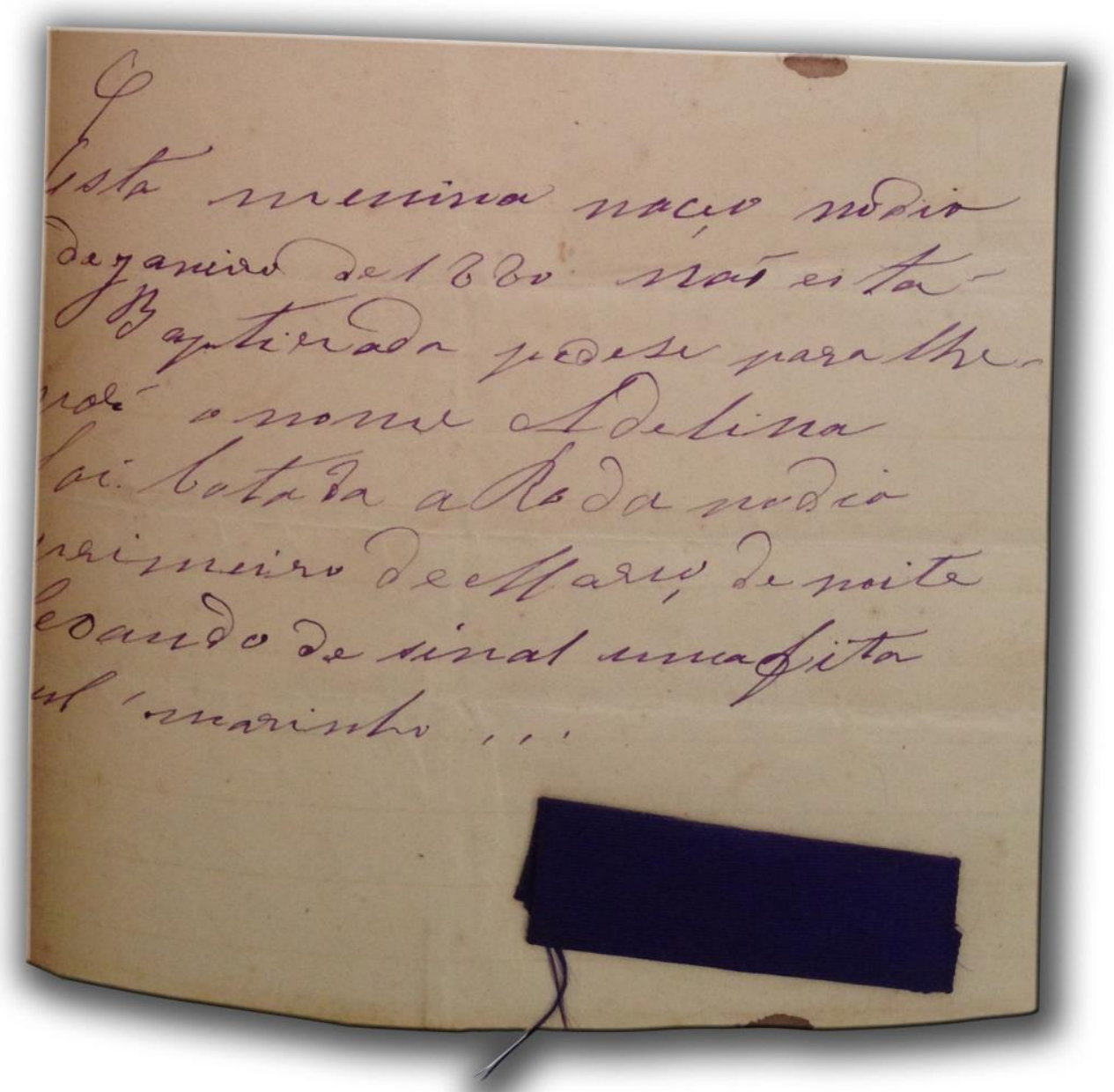


\|1r\| Esta menina naçeo no dia de Janeiro de1880 [espaço] não está [espaço] Baptizada pedese para lhe por o nome Adelina

5 foi botada a roda nodia primeiro de Março de noite [l]evando de sinal uma fita [az]ul 'marinho... ${ }^{72}$ 
ESCRITO 44 - ERD-SCMRJ - 1880

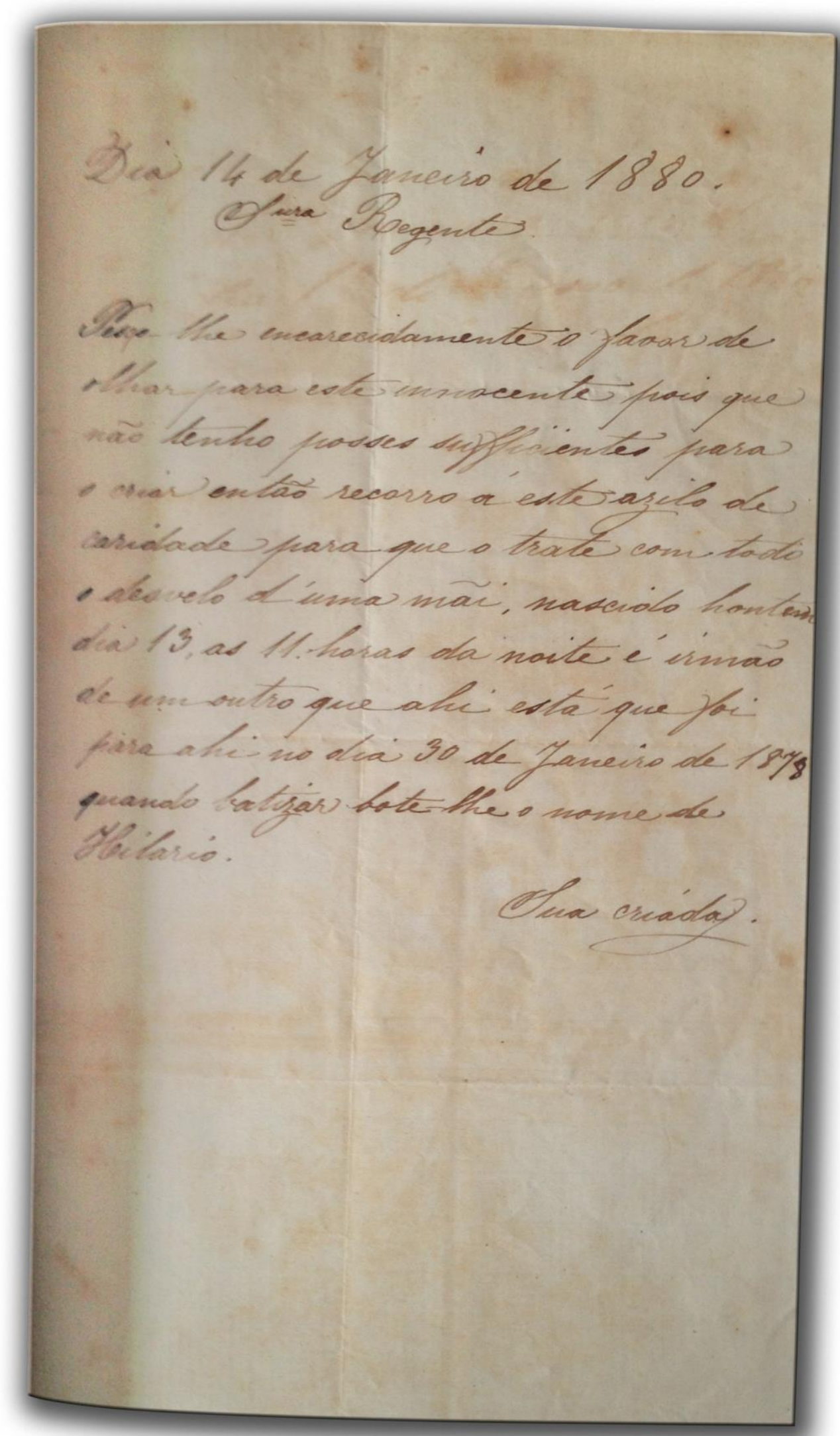


\|1r\| Dia 14 de Janeiro de 1880. Senhora Regente

Peço-lhe encarecidamente o favor de olhar para este innocente pois que

5 não tenho posses sufficientes para o criar então recorro à este azilo de caridade para que o trate com todo o desvelo deuma mãi, nascido hontem dia 13, as 11 horas da noite é irmão

10 de um outro que ahi está que foi para ahi no dia 30 de Janeiro de 1878 quando batizar bote-lhe o nome de Hilario. 
ESCRITO 45 - ERD-SCMRJ - 1858

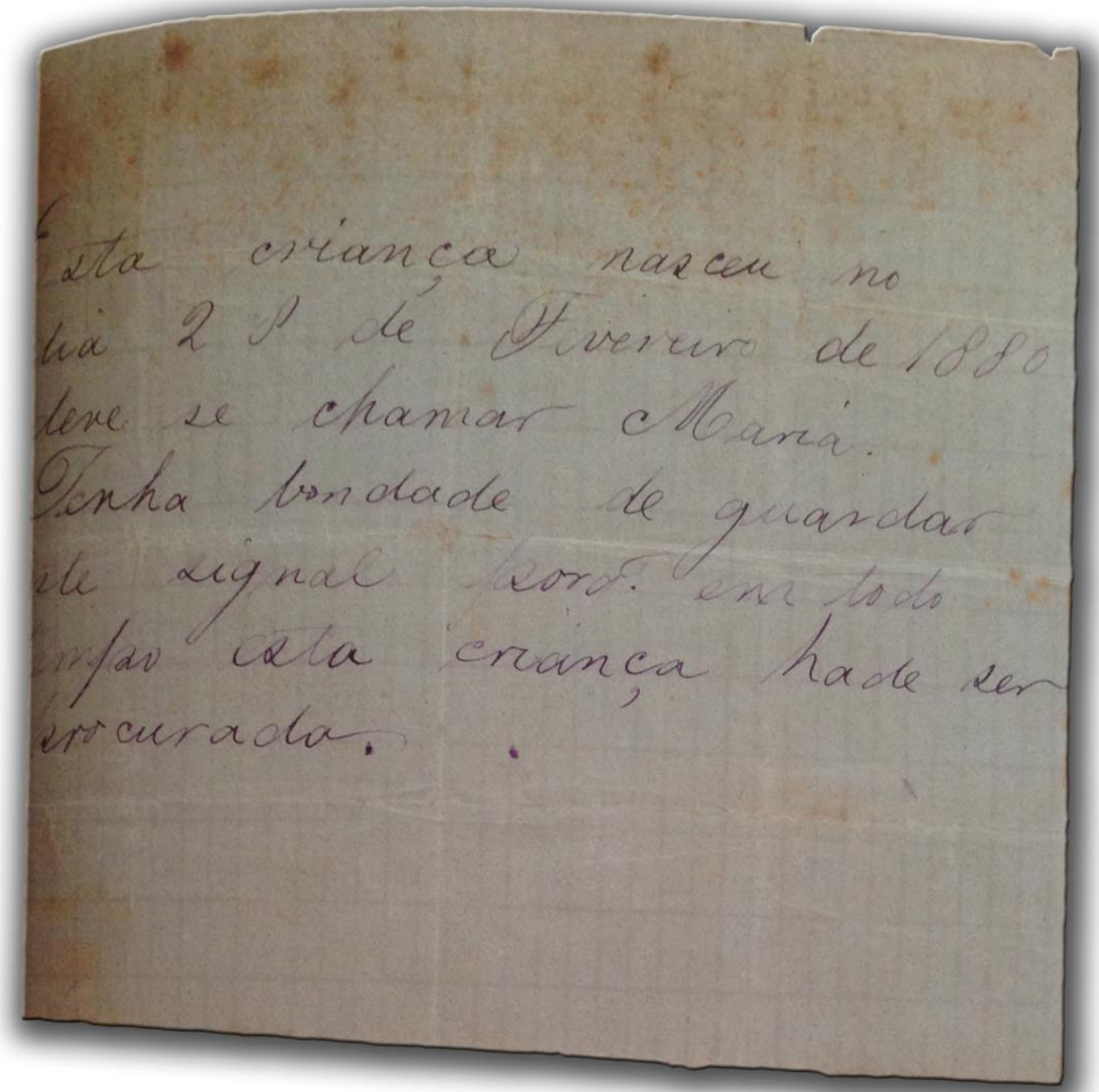


\|1r\| Esta criança nasceu no dia $28 \mathrm{P}$ de Fevereiro de 1880 deve se chamar Maria. Tenha bondade de guardar este signal por Favor em todo 5 tempo esta criança hade ser procurada. 
ESCRITO 46 - ERD-SCMRJ - 1880

Nöis orisue quic sasi expöe Esta pobre eriansa, innocentinba; O Alcas de sergenta eloftima pangida : Comfé, a triste Inte sôl-a confía: Bôas J̈rmàs, piedade pra polresinha.

$$
\text { "Wéodato" }
$$

Tox Sia sija-the coste nome dado, que best exprisne dua vituaçào; "sarita Mizericordia confiado näo faltará us infeliz protecệa. 
\|1r\| Não é o crime que aqui expõe Esta pobre criança, innocentinha; Mas de vergonha e lastima pungida Com fé, a triste Mãe vôl-a confia:

5 Bôas Irmãs, piedade pra pobresinha.

\|1v I _ "Déodato" Na $\bar{P}$ ia seja-lhe este nome dado, que bem exprime sua situação; á Santa Mizericordia confiado não faltará ao infeliz protecção. ${ }^{73,74}$

\footnotetext{
${ }^{73}$ Papel amarelo espresso, liso, semelhante a um papel-cartão

${ }^{74}$ Suporte com formato de pequeno retângulo com um dos lados arredondado, semelhante a uma etiqueta com um ilhó inserido no canto arredondado.
} 
ESCRITO 47 - ERD-SCMRJ - 1880

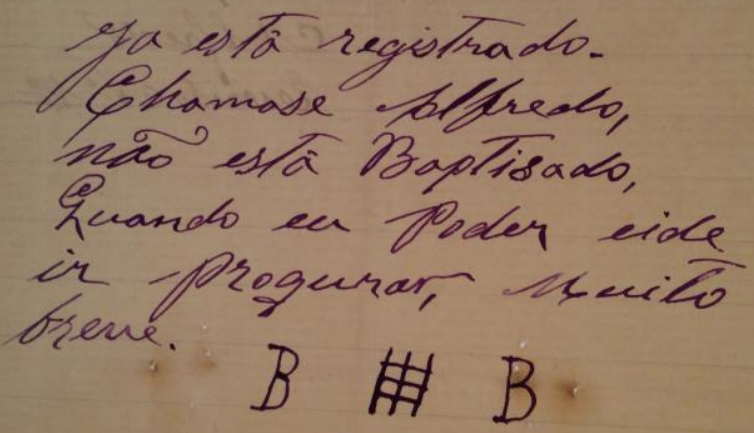


$\|1 \mathrm{v}\| \quad$ Ja está registrado.

Chamase Alfredo,

não está Baptisado,

Quando eu Poder eide

5 ir proqurar, muito

breve

$B[\#] B^{75}$

${ }^{75}$ Formato quadrado com os cantos superiores arredondados 
ESCRITO 48 - ERD-SCMRJ - 1901

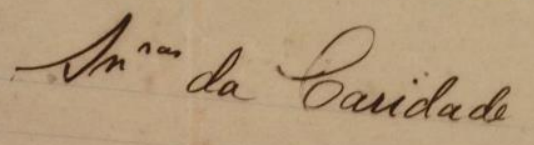

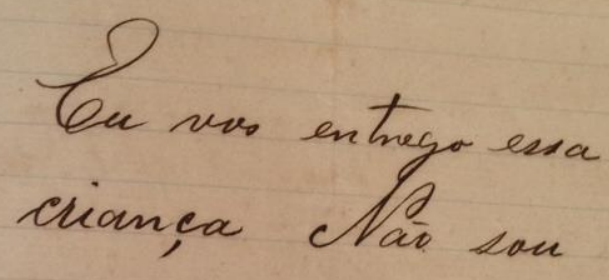

mai desnaturada!!

Tea traba thar!

a falta de recussas assim herdus e varsa caridade. Naser hofe as Pda manhà 22 de Junho 1901. Dever a ennola marcala com la b. 
\|1v\| Senhoras da Caridade

Eu vos entrego essa

criança Não sou

mai desnaturada!!

5 Vou trabalhar!

a falta de recursos assim

me permite Eu pesso

perdão e vossa caridade.

Nasseo hoje as 8 da manhã

1022 de Junho 1901.

E.C.

Pesso a esmola marcala com E.C. 
ESCRITO 49 - ERD-SCMRJ - 1903

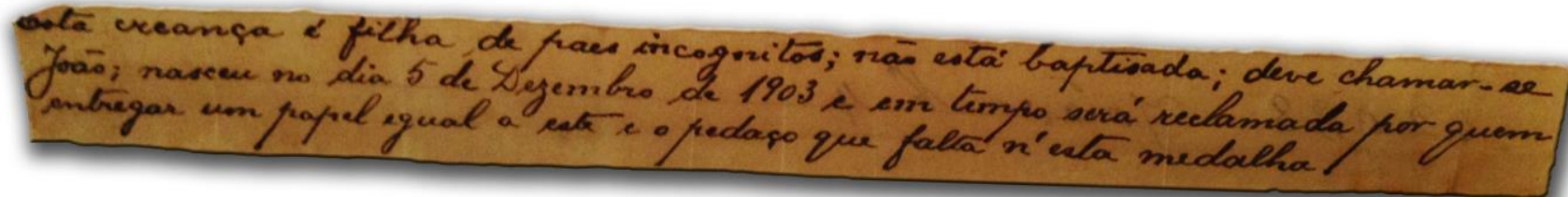


\|1v|| Esta creança é filha de pais incognitos; não está baptisada; deve chamar-se João; nasceu no dia 5 de Dezembro de1903 e em tempo será reclamada por quem entregar um papel egual a este e o pedaço que falta n'esta medalha ${ }^{76}$ 
186

ESCRITO 50 - ERD-SCMRJ - 1903

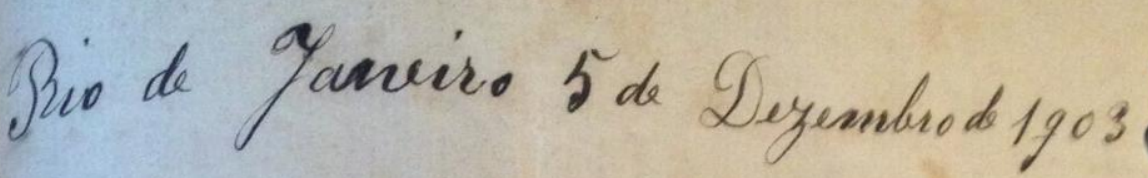

Uxinas Yresisas

Ceeo geeardar ssen fillso

ate' que as sucinhas foreas ormitas ir bused-ocom Insieds. Filhoehamave;

Yosée as que darei yaj:

una eofiera d'estar earla e unsa nedalha eosse o nonse

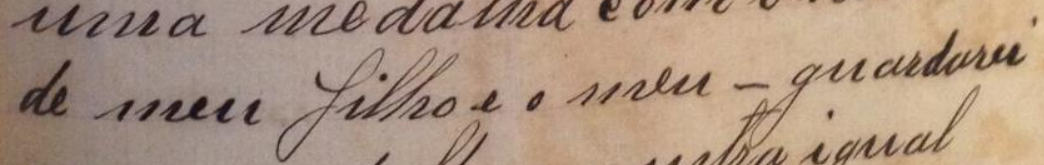
una inedatha e a mbla igual acomprastra sneer filvo.

Gassiasma

que fiea agraderida e pede a Duss jueta felieidade de bodos 
\|1v\| Rio de Janeiro 5 de Dezembro de 1903

Excelentissimas Irmãs

Peço guardar meu filho

até que as minhas forças

5 permittaõ ir buscal-o com

o auxilio [rasgado] ${ }^{77}$ s e das Boas

Irmãs, [rasgado] filho chama-se;

José e os [rasgado] que darei são;

uma copia d'esta carta e

10 uma medalha com o nome

de meu filho e o meu - guardarei

uma medalha e a outra igual

acompanha meu filho -

Cassianna

15 que fica agradecida e pede

a Deus pela felicidade de todos

${ }^{77}$ Recorte quadrado com bordas irregulares na parte central do escrito 
ESCRITO 51 - ERD-SCMRJ - 1955

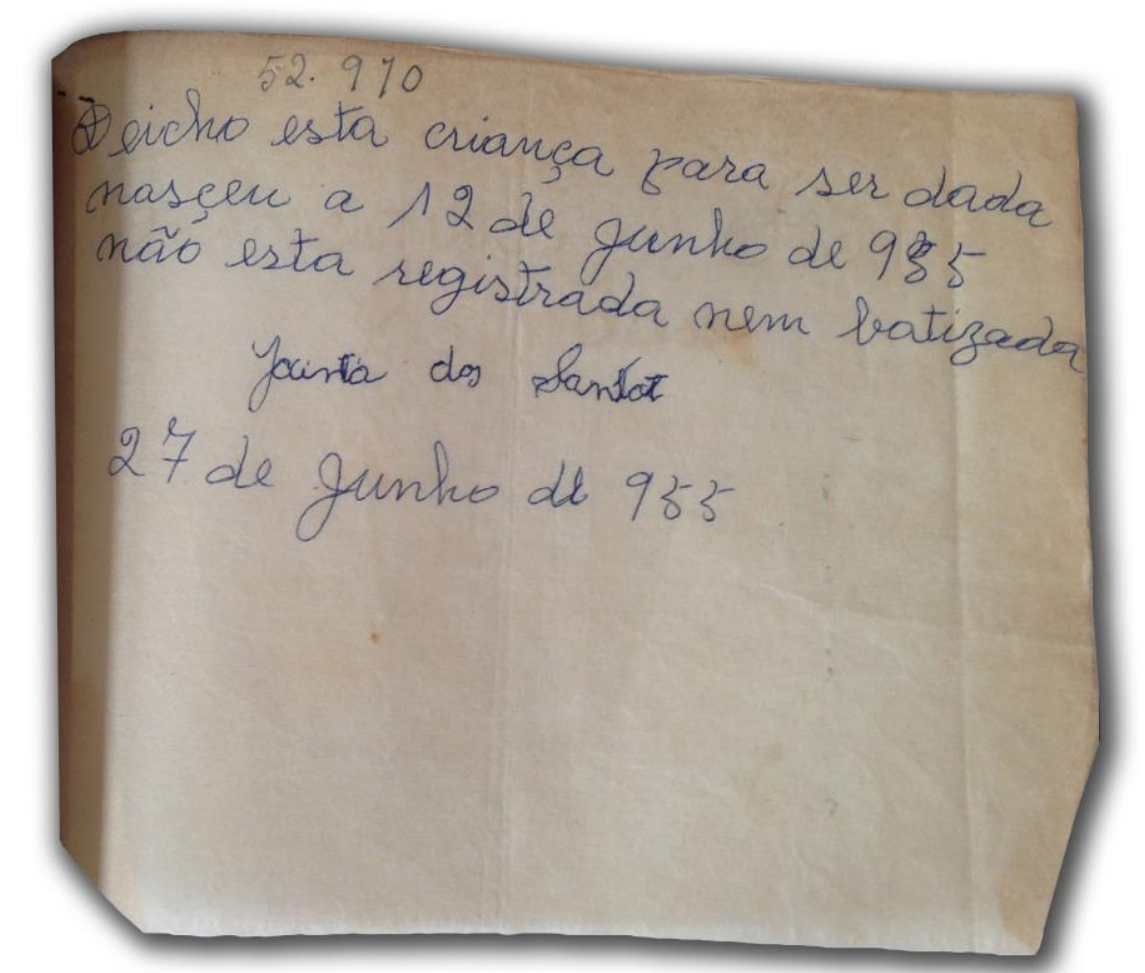


$<52.970>$

\|1v\| Deicho esta criança para ser dada nasçeu a 12 de Junho de 955 não esta registrada nem batizada

5 Jacinta dos Santos

27 de Junho de 955 
TRANSCRIÇÃO SEMIDIPLOMÁTICA DOS ESCRITOS DE SÃO PAULO

ESCRITO 52 - MSC-SP - 1917

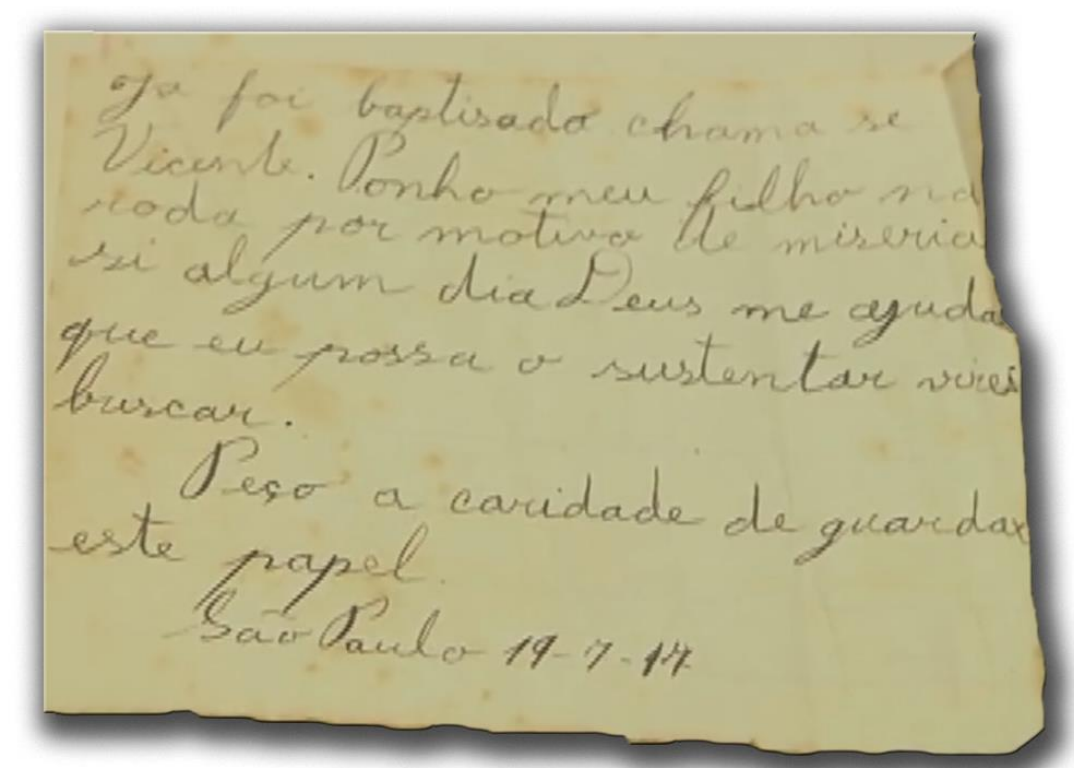


\|1v\| Já foi baptisado chama se Vicente. Ponho meu filho na roda por motivo de miseria si algum dia Deus me ajudar 5 que eu possa o sustentar virei buscar.

Peço a caridade de guardar este papel.

São Paulo 19-7-17 
ESCRITO 53 - MSC-SP - 1920

barlos Sema

Bascido a 21 de Setembro de 1990 ga for baptisado

Sede-se a caridade de con sevar como roliquia sagrada. a correntinha com a medalha. da 'Cirgem da Gonceiciad, no pescocinto, que é cumprimento de uma fromesia.

I. Paulo, 1\% des. Cutuber de 1920 
\|1\| Carlos Penna

Nascido a 21 de Setembro de 1920 Já foi baptisado.

Pede-se a caridade de con-

5 servar como reliquia sagrada. a correntinha com a medalha da Virgem da Conceição, no pescocinho, que é cuprimento de uma promessa.

10 S. Paulo, $17^{78}$ de Outubro de 1920

\footnotetext{
${ }^{78}$ Número 7 sobreposto ao númemro cinco.
} 
ESCRITO 54 - MSC-SP - 1921

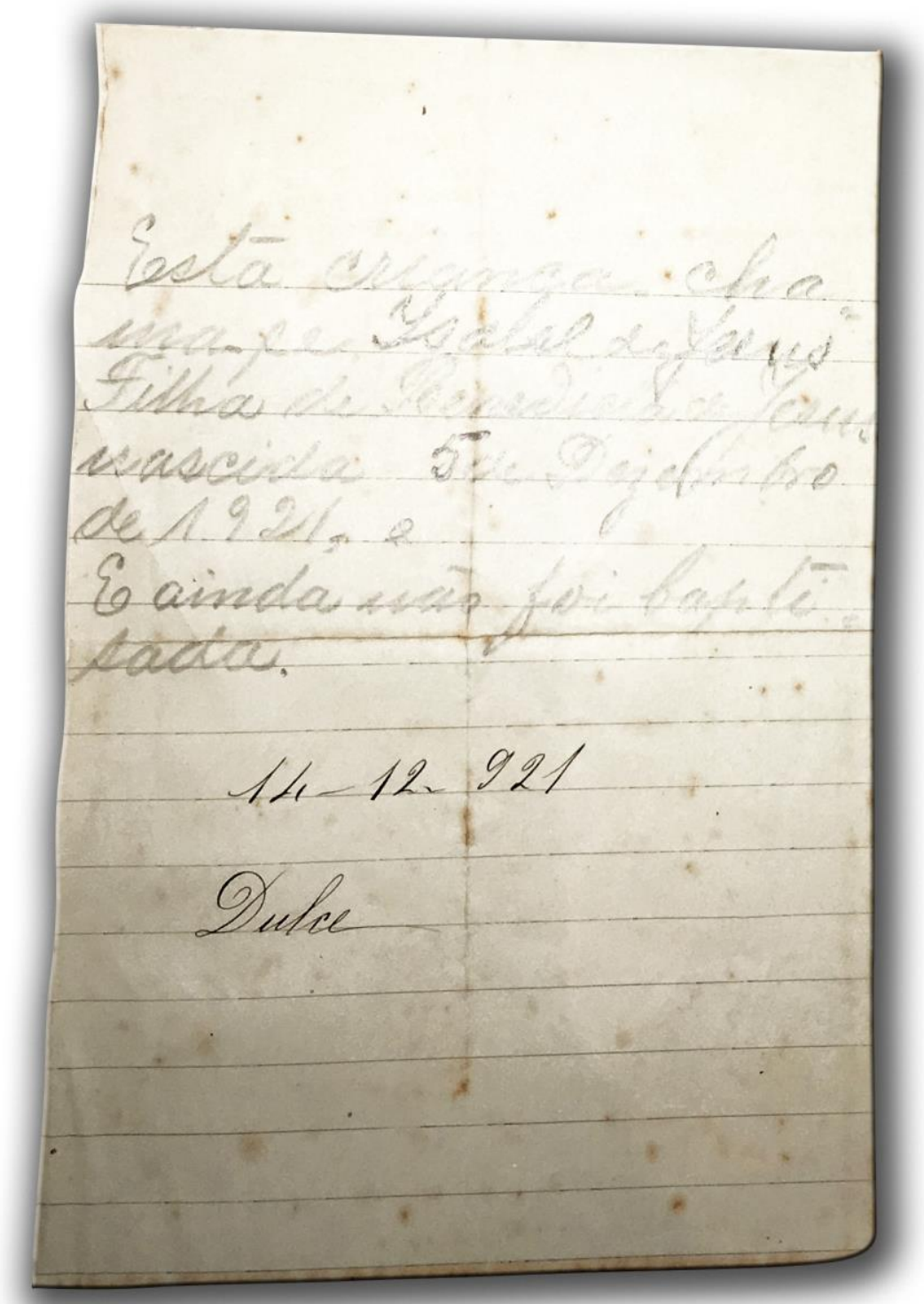


\|1\| Esta criança cha-

ma-se Isabel de Jesus

Filha de Benedicta de Jesus

nascida 5 de Dezembro

5 de 1921.

E ainda não foi bapti-

sada.

$14-12-921^{79}$

Dulce

${ }^{79}$ A data cronológica e a assinatura foram realizadas com outro instrumento de escrita. Pode sugerir uma anotação tardia. 
ESCRITO 55 - Página 1 - MSC-SP - 1922

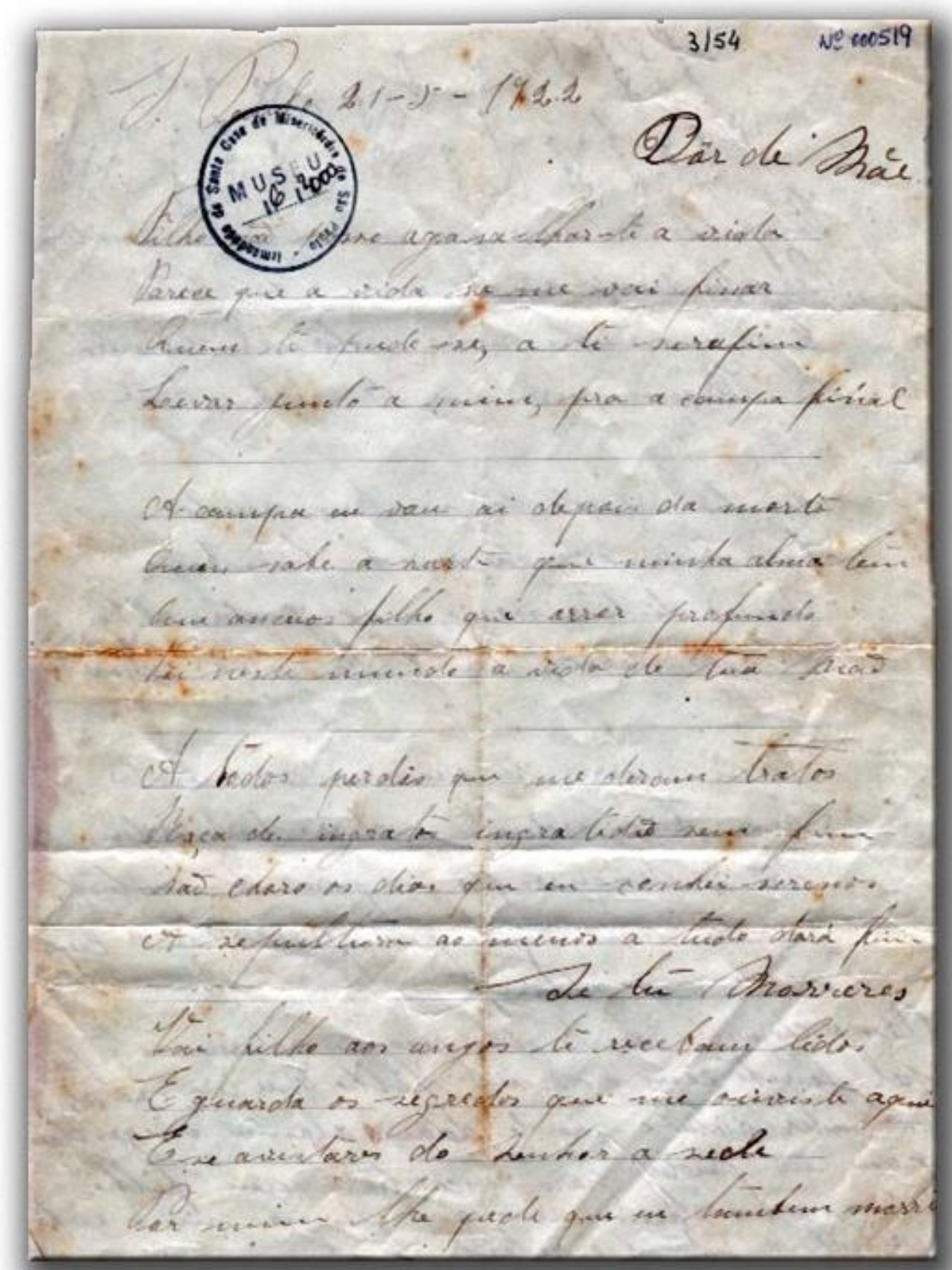


$<3 / 54><$ Numero 000519>

\|1r|| Saõ Paulo 21-2-1922

Dôr de Mãe

Filho não posso agasa Ihar-te a vida

Parece que a vida se me vai finar

5 Quem te pude-se, a ti serafim

Levar junto-a mim, pra a campa finál

A campa eu vou ai depois da morte Quem sabe a sorte que minha alma tem Que anceios filho que amor profundo

10

Vai neste mundo a vida de tua mãe

A todos perdão que me deram tratos Raça de ingratos ingratidão sem fim Não choro os dias que eu sonhei serenos A sepultura ao menos a tudo dará fim

15

Se tu Morreres

Vai filho aos anjos te recebam lidos

$E$ guarda os segredos que me ouvis te aqui

E se avistares do Senhor a sede

Por mim lhe pede que eu tambem morri 
ESCRITO 55 - Página 2 - MSC-SP - 1922

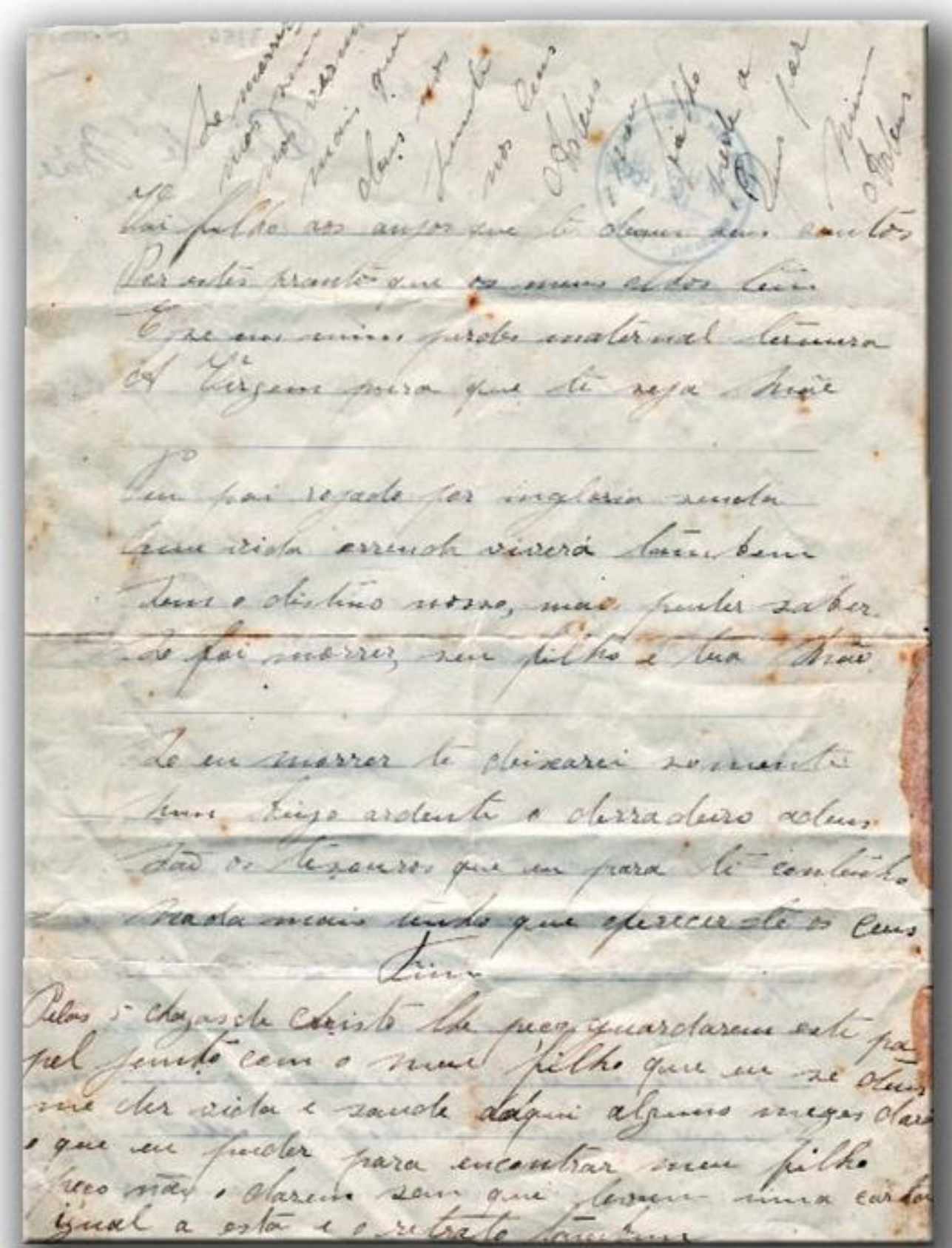


$\|1 v\|<$ Se morrer- | mos sem| nos vermos | mais que | deus nos | junte nos Ceus | Adeus | meu | filho | pede a | Deus por | mim | Adeus $>80$

Vai filho aos anjos que te deram seus cantos

Por estes prantos os meus olhos tem

E se em mim perdes maternal ternura

5 A Virgem pura que te seja Mãe

Teu pai rogado por ingloria senda

Que vida orrenda viverá tambem

Sem o distino nosso, mais puder saber

Se foi morrer, seu filho e tua Mãe

10 Se eu morrer te deixarei somente meu beijo ardente o derradeiro adeus

São os tesouros que eu para ti contenho

Nada mais tendo que oferecer-te os Ceus

[espaço] Fim [espaço]

15 Pelas chagas de Christo Ihe peço guardarem este pa-

pel junto com o meu filho que eu se deus

me der vida e saude daqui alguns mezes darei

o que eu puder para encontrar meu filho

peço não o darem sem que levem uma carta

20 igual a esta e o retrato tambem

${ }^{80}$ Escrita no cabeçalho da folha, em diagonal. 
ESCRITO 56 - MSC-SP - 1922

Sor praulo 30 de enaic de 1923.

Foço Pabrer que Esta of Pacen no lis

8 de yaniire de 922 .

e fitha de Mario de sacclas, comen

Antornis I. Limar rea ya falccida nó

dia 20 de mais de 1922 , cosser a'edade

17 anno. elle, vilie con a'udade

de 19 anno antios Prajeilecio.

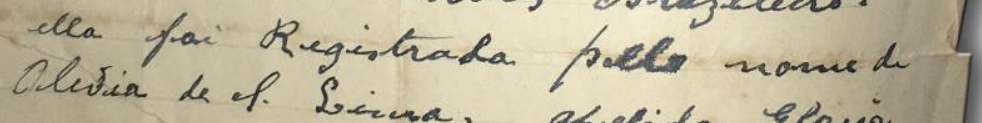
afrelindo, Elasia 
||1| São paulo 30 de Maio de 1922.

Faço Saber que Este Naceu no dia

8 de Janeiro de 1922.

e filha de Maria de paula, com

5 António S. Lima, elle já falecido nò

dia 20 de maio de 1922, com à idade

17 annos. [espaço] ella, ViVe com à idade

de 19 anno anbòs Brazileiro.

ella foi Registrada pelo nome de

10 Olevia de S. Lima. [espaço] apelido, Gloria 
ESCRITO 57 - Página 1 - MSC-SP - 1922

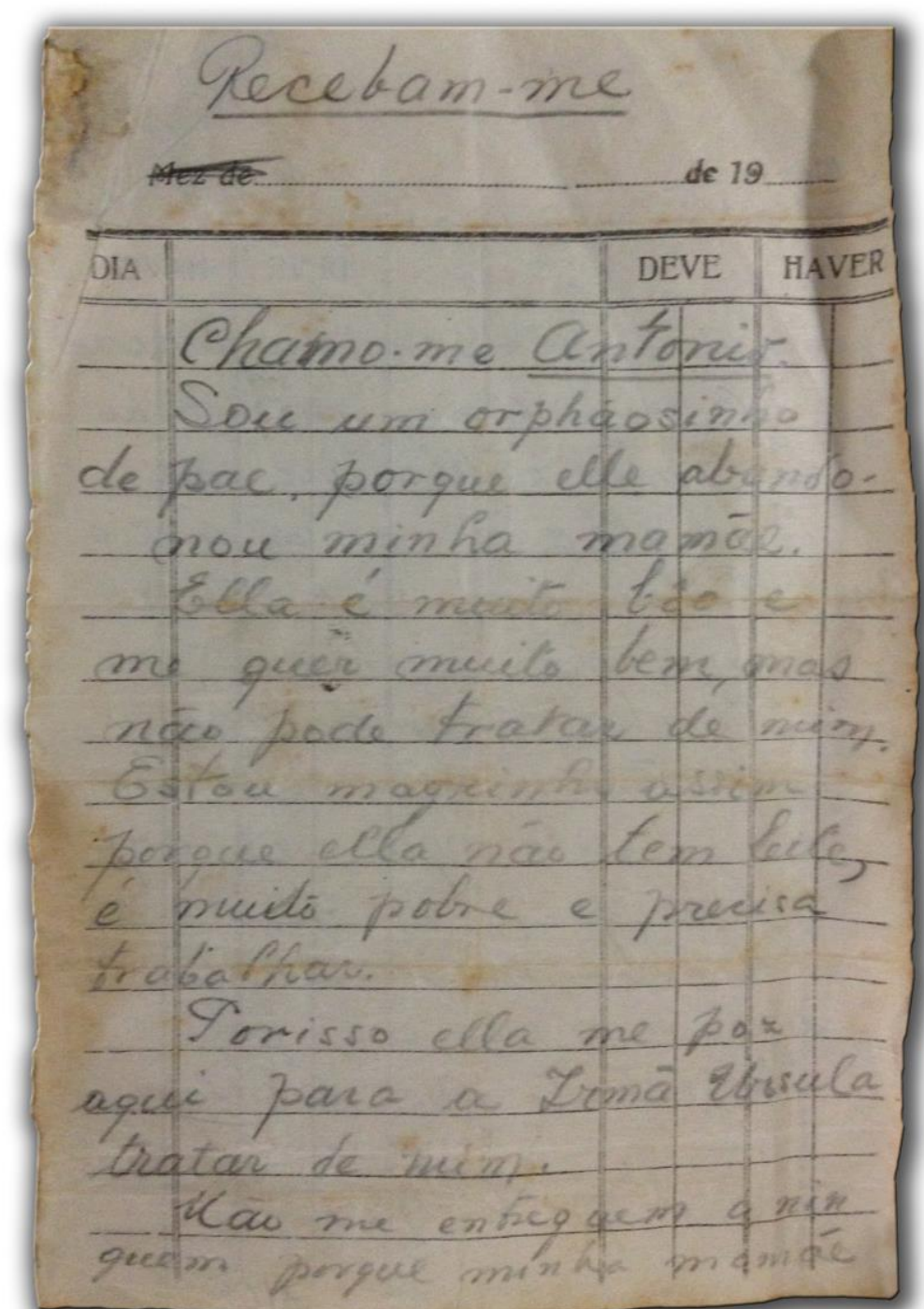


\|1r\| $\quad \underline{\text { Recebam-me }}$

Chamo-me Antonio.

Sou um orphãosinho

de pae, porque elle abando-

5

nou minha mamãe.

Ella é muito boa e

me quer muito bem, mas

não pode tratar de mim.

Estou magrinho assim

10 porque ella não tem leite,

é muito pobre e precisa

trabalhar.

Porisso ella me poz

aqui para a Irmã Ursula

15 tratar de mim.

Não me entreguem a ninguém porque minha mamãe 
ESCRITO 57 - Página 2 - MSC-SP - 1915

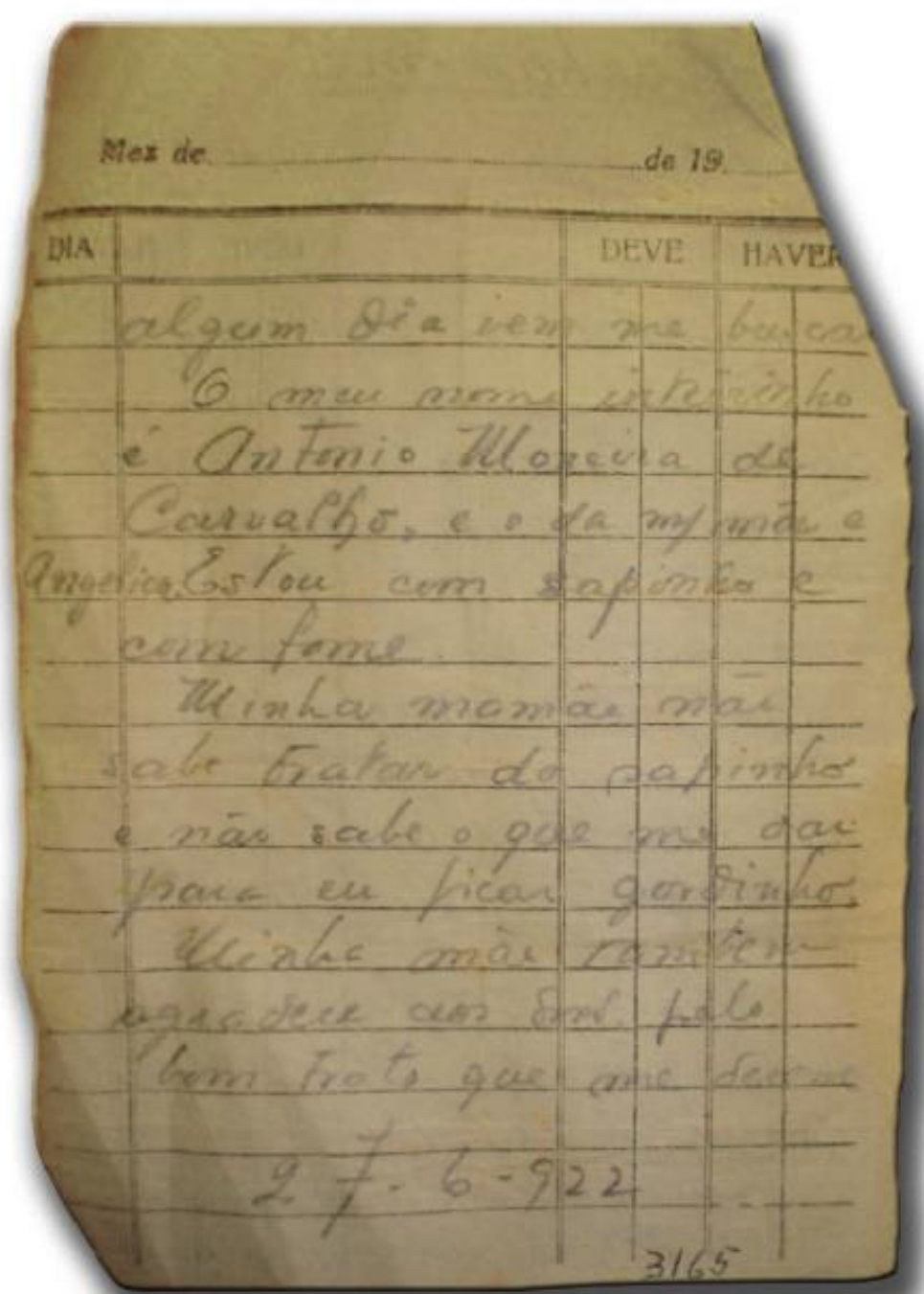


$\|1 \mathrm{v}\| \quad$ algum dia vem me buscar

O meu nome inteirinho

é Antionio Moreira de

Carvalho, e o da minha mãe e

5 Angelica. Estou com sapinho e

com fome.

Minha mamãe não

sabe tratar do sapinho

e não sabe o que me dar

10

para eu ficar gordinho.

Minha mãe também

agradece aos Senhores pelo

bom trato que me derem.

15

$27-6-922$

$<3165>^{81,82}$

\footnotetext{
${ }^{81}$ Anotação tardia

${ }^{82}$ Manuscrito realizado em folha de livro Caixa
} 
ESCRITO 58 - MSC-SP - 1922
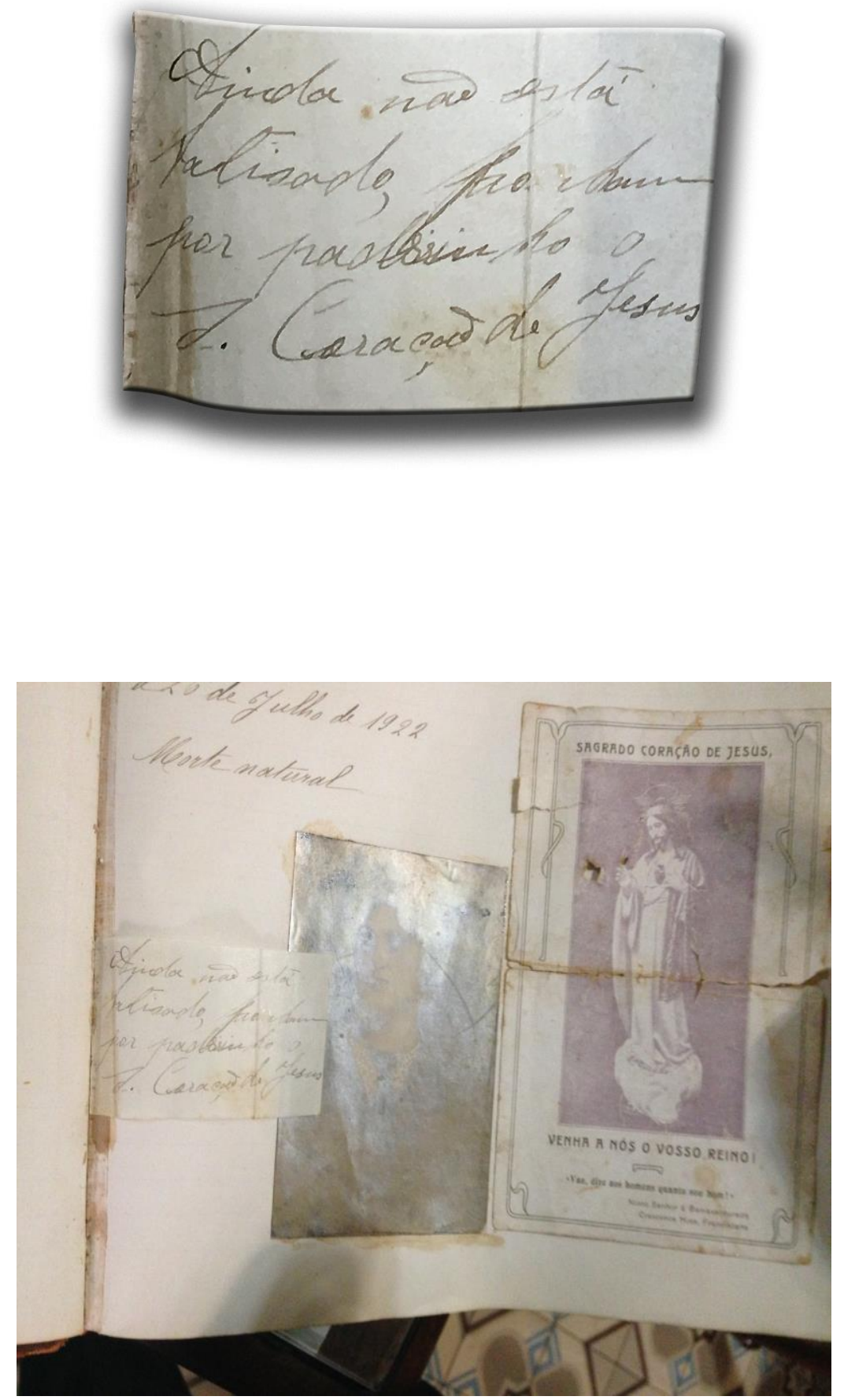
\|1r\| Ainda não está

[ba]tisado [peço darem]

por padrinho o

Sagrado Coração de Jesus ${ }^{83,84}$

${ }^{83}$ Com o escrito, estava arquivado junto ao escrito uma fotografia e o santinho do Sagrado Coração de Jesus

${ }^{84} \mathrm{O}$ suporte da escrita é um pequeno retângulo de papel de seda 
ESCRITO 59 - Página 1 - MSC-SP - 1923

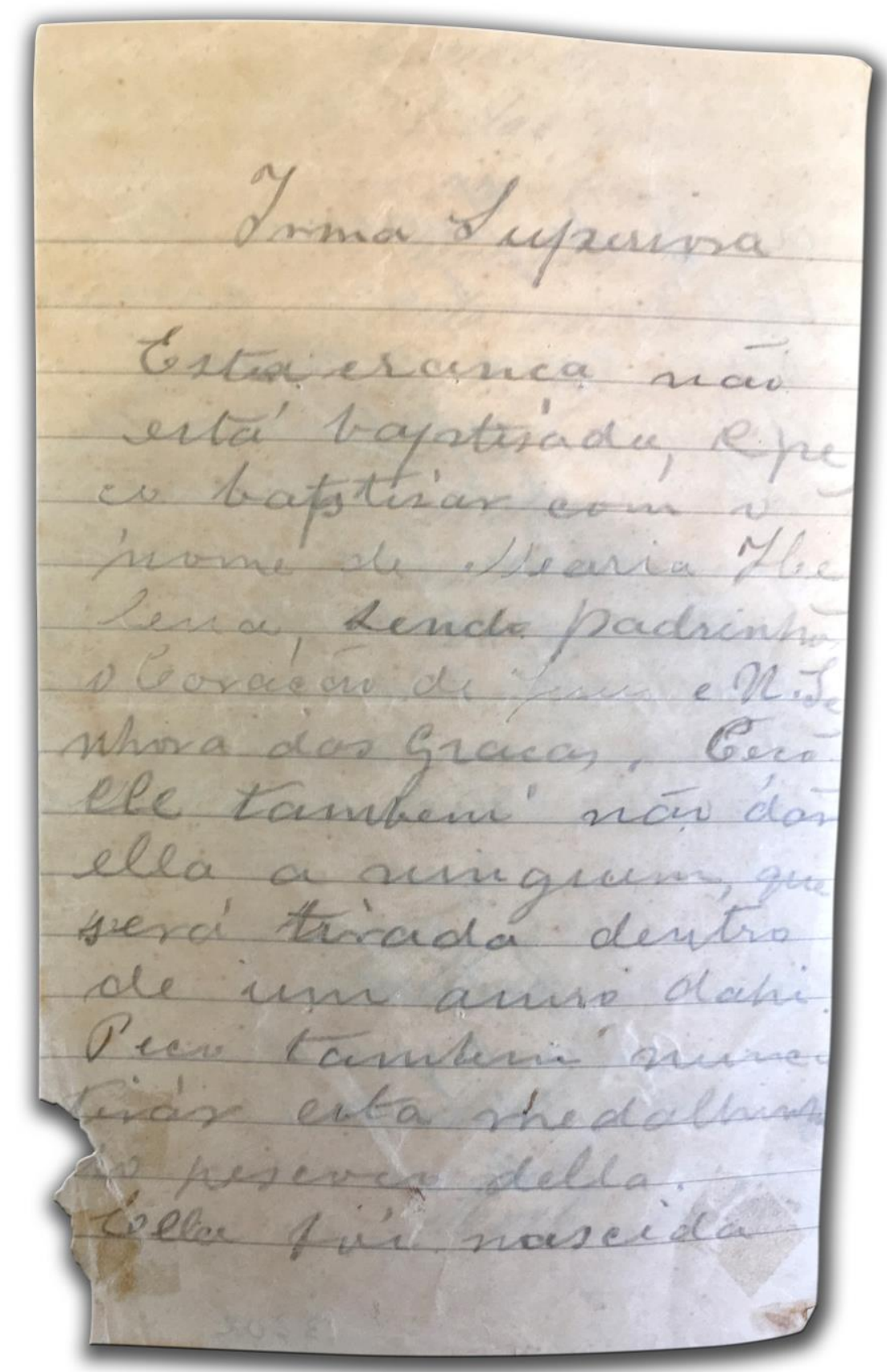


||1r\| Irmã Superiora

Esta crança não

está baptisada, e pe-

ço baptisar com o

5 nome de Maria He-

lena, sendo padrinhos

o Coração de Jesus e Nossa Se-

nhora das Graças, Peço

ele também não dar

ella a ninguem, qu[e]

10 será tirada dentro

de um anno dah[i]

Peço tambem nun[ca]

tirar esta medalha

do pescoço della. ${ }^{85}$

tirar esta medalha

do pescoço della.

Ella foi nascida

${ }^{85}$ Tardiamente um pedaço do papel foi extraído no canto inferior esquerdo 
ESCRITO 59 - Página 2 - MSC-SP - 1915

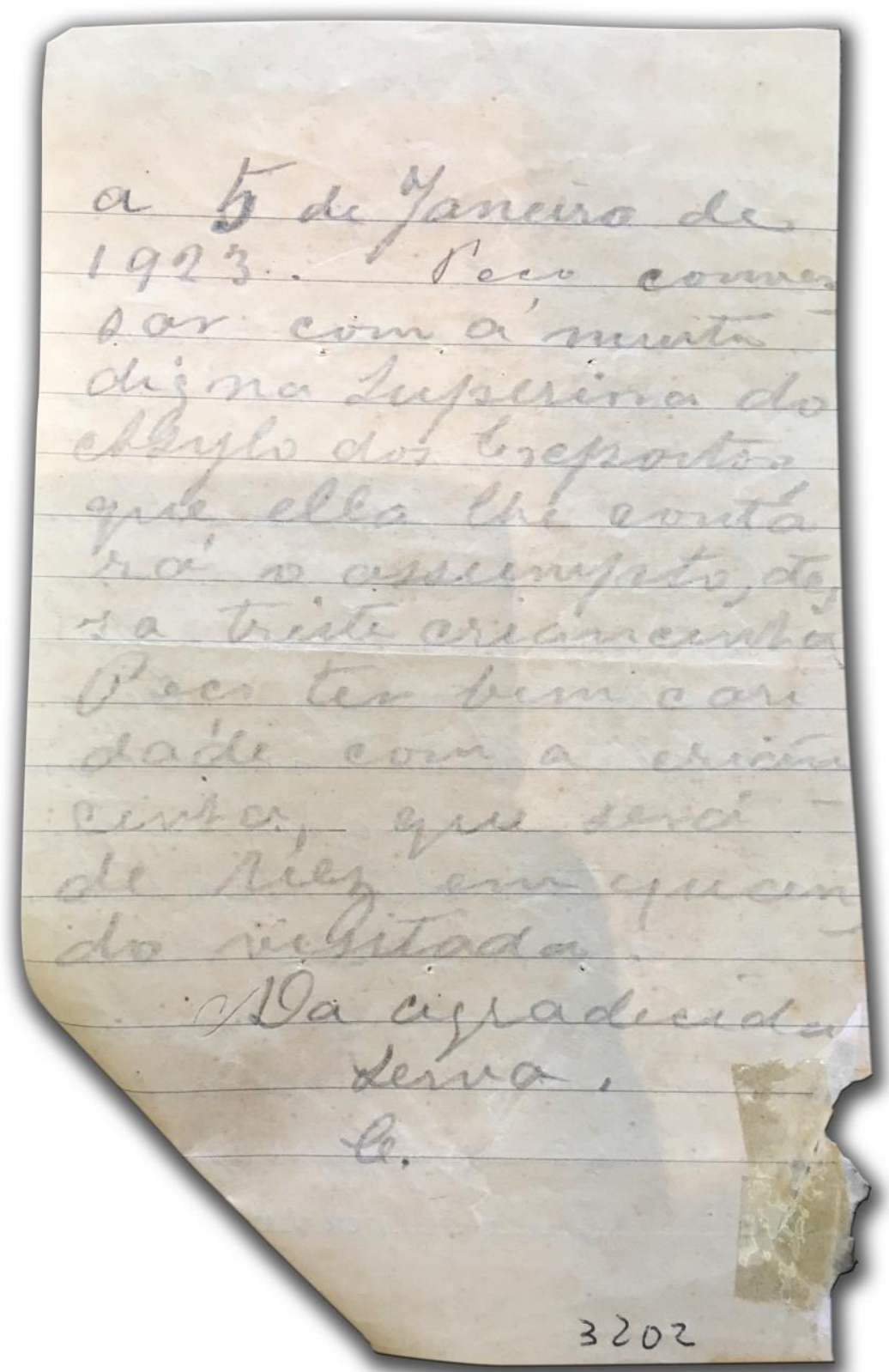


\|1v\| a 5 de Janeiro de 1923, Peço conversar com a muita digna Superiora do

5 Asylo dos Expostos que ella lhe conta rá o assumpto, des sa triste criancinha. Peço ter bem a cari

10 dade com a crian cinha, que de vez en quan do espero visitado

Da agredecida Serva

15 C. 


\section{ESCRITO 60 - MSC-SP - 1923}

\section{Qav vaulo, if-10-923}

Encontarando-me eu, à muito fempes duente, eagora por minha infelicin dade, deil a Luy duas Preancas, vego-me desamparada e sem recar. ssos, para o meir alimento, e nem para - das esencas, pois tenho mais trez filhinhos piquenos, tendos mais arelho sete amos, peco pois, is Dy pras irmãs, terem Compaixao, d'esta inocen le, se minka sorte, for mi lhor para ofutur, eu reconhecerlei ás foàs irmäs de carí. dade,

Dem mais recebam Comprimentos de un pace máe que se veem afflitas
de dar e sem recurssos. 
Saõ Paulo, 4-10-923

Encontrando-me eu, á muito tempo duente, e agora por minha infelici= dade, dei à Luz duas Creanças,

5 vego-me desamparada e sem recurssos, para o meu alimento, e nem para o das crenças, pois tenho mais trez filhinhos piquenos, tendo o mais velho sete annos, peço pois, ás Dignissimas irmãs,

10 terem Compaixão, d'esta inocente, se minha sorte, for milhor para o futuro, eu reconhecerei ás boás irmãs de cari= dade.

Sem mais recebam Comprimentos de um páe e máe que se veem afflitos

15 de dôr e sem recurssos. 


\subsubsection{Fichas codicológicas}

A fim de se desenvolver a descrição codicológica dos documentos do corpus, adotaram-se as fichas codicológicas com o preenchimento de alguns de 9 dos itens do modelo proposto por Cambraia (2005, p. 28), conforme se explicita a seguir. De acordo com o exemplo de descrição codicológica proposto por Monte (2008/2009), adaptado às especificidades e necessidades dos documentos que compõem o corpus, mantiveram-se os itens da "cota", da "datação" e do "lugar de origem". O tópico "folha de rosto" do modelo proposto por Cambraia foi alterado para a "reprodução da primeira linha", para facilitar a identificação do escrito. Eliminou-se o item "colofão", por inexistir no corpus. Ainda conforme Cambraia (2005, p. 28), mantiveram-se as partes em que se descrevem o "suporte material", a "composição", a "organização da página", as "particularidades" e o "conteúdo", "eliminando-se o tipo de encadernação" e as "descrições prévias". Sendo assim, organizou-se abaixo um modelo de ficha codicológica a partir da qual se descreve, a seguir, cada um dos 60 documentos. 
Figura 18 - Modelo de ficha codicológica

Ficha Codicológica explicativa

1. Cota: cidade onde se encontra arquivado atualmente o documento; nome da instituição de guarda; coleção a que pertence o escrito e possível identificação do número de registro do exposto na instituição que o recebera.

2. Datação: data cronológica de produção do escrito, conforme grafado no próprio documento, seja apenas o ano ou a data completa, com dia, mês e ano.

3. Lugar de origem: data tópica, constando o nome da cidade onde se produziu o documento, igualmente, conforme redigido no próprio documento.

4. Reprodução da primeira linha: transcrição semidiplomática da primeira linha do dado escrito para fins de identificação.

5. Suporte material: descrição sumária do papel em que o escrito se encontra registrado. Descreve-se também se há pautas impressas.

6. Composição: quantidade de folhas que compõem o documento. Formato empregado, com as medidas da altura (A) e da largura (L) em centímetros.

7. Organização da página: pontua-se se a folha ou parte de folha é avulsa, o que acontece em todos os documentos do corpus e a quantidade de linhas grafadas. Ressalta-se que as anotações tardias que, geralmente, informam o número de registro do exposto, não foram consideradas na contagem das linhas dos escritos.

8. Particularidades: indicação da existência de elementos gráficos como a apresentação das assinaturas ou outros sinais de identificação do autor material, bem como elementos extratextuais como os sinais, comumente deslocados da mancha do texto.

9. Conteúdo: essencial à consulta prévia dos documentos, este item apresenta uma síntese do que comunica o escrito em questão.

\section{ESCRITO 1}

1. Cota: Lisboa; Arquivo AH-SCML; Escritos dos expostos; Exposto $\mathrm{n}^{\circ} 1040$.

2. Datação: 1790.

3. Lugar de origem: Lisboa.

4. Reprodução da primeira linha: "Para aCaza daSanta Mezericordia".

5. Suporte material: papel sem pauta.

6. Composição: escrito manuscrito somente na frente, formato retangular; L: $20 \mathrm{~cm} \times \mathrm{A}: 14 \mathrm{~cm}$.

7. Organização da página: folha solta, 9 linhas escritas.

8. Particularidades: Não há assinatura. Há anotação do número do exposto, escrita posteriormente e por outro punho.

9. Conteúdo: o texto informa hora e dia do nascimento da criança e que não está batizada, sugerindo que seja chamada de Maurício. Descreve duas peças de enxoval que vão com a criança e informa que os itens estão velhos. Pede ainda que seja criada com zelo em Lisboa, pois em tempo oportuno será procurada. 


\section{ESCRITO 2}

1. Cota: Lisboa; Arquivo AH-SCML; Escritos dos expostos; Exposto nº 1990.

2. Datação: 1790.

3. Lugar de origem: Lisboa.

4. Reprodução da primeira linha: "Ahi vay hese Menino com hidade de hum mes".

5. Suporte material: papel sem pauta.

6. Composição: escrito manuscrito somente no recto, formato retangular; $A$ : $21 \mathrm{~cm}$; L: $18 \mathrm{~cm}$.

7. Organização da página: folha solta, 11 linhas escritas.

8. Particularidades: não há assinatura.

9. Conteúdo: o texto informa a idade da criança e que ela não está batizada. Afirma que a criança deve ser chamada de Joze Theadoro e relaciona o enxoval que a acompanhava. Solicita que se guarde o escrito, pois os pais pretendem buscá-la em breve e pede ainda que ela não seja enviada para longe.

1. Cota: Lisboa; Arquivo AH-SCML; Escritos dos expostos; Exposto no 1141.

2. Datação: 1790.

3. Lugar de origem: Lisboa.

4. Reprodução da primeira linha: "Ainda naõ está baptizado: pede-se que".

5. Suporte material: papel sem pauta.

6. Composição: recorte irregular de papel, escrito manuscrito somente frente, formato retangular; A: $5 \mathrm{~cm}$ nas partes menores e $7 \mathrm{~cm}$ nas partes maiores; $\mathrm{L}: 11 \mathrm{~cm}$.

7. Organização da página: folha avulsa, 3 linhas escritas.

8. Particularidades: não há assinatura. O número do exposto foi incluído acima do texto do escrito tardiamente, por outro punho e instrumento de escrita.

9. Conteúdo: o texto informa que a criança não está batizada, solicita que ela seja chamada de João Carneiro e informa que o sinal que leva é o presente bilhete.

\section{ESCRITO 4}

1. Cota: Lisboa; Arquivo AH-SCML; Escritos dos expostos; Exposto no 1573.

2. Datação: 1798.

3. Lugar de origem: Lisboa.

4. Reprodução da primeira linha: "Esta menina vai já Batizada Nasceo no dia 6 feira 28 de".

5. Suporte material: papel sem pauta, similar ao papel vergê, azul claro.

6. Composição: escrito manuscrito somente frente, redigido a partir da base, $A$ : $8 \mathrm{~cm}$; L: 15,5cm; Diagonal 16,5cm; papel em formato de triângulo-retângulo com corte oblíquo e saliência em sua parte central.

7. Organização da página: folha avulsa, 10 linhas escritas

8. Particularidades: papel azul. A anotação do número do exposto foi inserida por outro punho justamente entre as palavras "Joaquina" e "anacenso". Iniciais da assinatura na ponta do triângulo.

9. Conteúdo: o texto informa que a criança está batizada, a data de nascimento e relaciona os itens de enxoval que acompanham a criança. Acrescenta que a criança será procurada por pessoa que levará outro escrito contendo o mesmo teor. 


\section{ESCRITO 5}

1. Cota: Lisboa; Arquivo AH-SCML; Escritos dos expostos; Exposto nº 618.

2. Datação: 1800.

3. Lugar de origem: Lisboa.

4. Reprodução da primeira linha: "Esta menina naseo adozasete domes demaio porseia".

5. Suporte material: papel sem pauta.

6. Composição: escrito manuscrito, escrito somente frente, formato retangular; $A$ : 14cm; L: 19cm; com recorte irregular na parte inferior da margem.

7. Organização da página: folha avulsa, 4 linhas escritas.

8. Particularidades: Fita cor-de-rosa perpassada verticalmente.

9. Conteúdo: o texto informa dia, mês e ano do nascimento da criança, sugere que deve ser chamada de Henriqueta. Informa que leva uma fita de Nossa Senhora do Cabo.

\section{ESCRITO 6}

1. Cota: Lisboa; Arquivo AH-SCML; Escritos dos expostos; Exposto no 214.

2. Datação: 1800.

3. Lugar de origem: Lisboa.

4. Reprodução da primeira linha: "Entrego na Santa Caza de Misericordia Eua inposta".

5. Suporte material: papel sem pauta.

6. Composição: escrito manuscrito somente frente, formato retangular, $A: 17 \mathrm{~cm}$; L: 22.

7. Organização da página: folha avulsa, 9 linhas escritas.

8. Particularidades: não há assinatura; há uma fita de seda que perpassa na terceira linha do texto, recobrindo dois segmentos dele. A anotação do número do exposto fora escrita posteriormente e por outro punho.

9. Conteúdo: o texto informa que a criança deve ser chamada de Tomazia. Descreve o enxoval que acompanha a criança, afirma que o sinal principal é um laço de fita branca que está no braço esquerdo da criança e solicita que seja tratada com caridade.

\section{ESCRITO 7}

1. Cota: Lisboa; Arquivo AH-SCML; Escritos dos expostos; Exposto no 415.

2. Datação: 1800 .

3. Lugar de origem: Lisboa.

4. Reprodução da primeira linha: "Entre pa a Santa Caza da Mizericordia esta".

5. Suporte material: papel sem pauta.

6. Composição: escrito manuscrito somente frente, formato retangular; $A: 30 \mathrm{~cm}$; L: $21 \mathrm{~cm}$; recorte irregular do papel na parte esquerda.

7. Organização da página: folha avulsa, 7 linhas escritas.

8. Particularidades: duas linhas de anotações, incluindo o número do exposto realizadas tardiamente e por outro punho. Não há assinatura. Papel com o timbre do 10 réis, que indica o valor do papel. Hastes e desenhos de flores na margem esquerda do texto.

9. Conteúdo: o texto informa a data de nascimento da criança, que não está batizada e que seu nome deve ser Maria. Informa ainda que será retirada. 


\section{ESCRITO 8}

1. Cota: Lisboa; Arquivo AH-SCML; Escritos dos expostos; Exposto $\mathrm{n}^{\circ} 1712$.

2. Datação: 1838.

3. Lugar de origem: Lisboa.

4. Reprodução da primeira linha: "Nasceu esta menina no dia 14 de Novembro de 1838 ".

5. Suporte material: papel sem pauta.

6. Composição: escrito manuscrito somente frente; recorte irregular na parte inferior do papel; formato retangular; A: $11,5 \mathrm{~cm}$; L: $18 \mathrm{~cm}$.

7. Organização da página: folha avulsa, 4 linhas escritas.

8. Particularidades: a anotação do número do exposto foi inserida por outro punho tardiamente no verso do escrito. Não há assinatura. Apresenta orelha na parte superior esquerda e na parte inferior direita em função do tempo e da fina espessura do papel.

9. Conteúdo: o texto informa a data de nascimento da criança, que deve ser chamada de Paulina e relaciona itens de enxoval que a acompanham.

\section{ESCRITO 9}

1. Cota: Lisboa; Arquivo AH-SCML; Escritos dos expostos.

2. Datação: 1839.

3. Lugar de origem: Lisboa.

4. Reprodução da primeira linha: "hoje 9 de abril de 1839 entro para”.

5. Suporte material: papel sem pauta.

6. Composição: escrito manuscrito somente frente; recorte de papel retangular; A: 7cm; L: 14,5cm.

7. Organização da página: folha avulsa, 8 linhas escritas.

8. Particularidades: há assinatura no canto inferiror esquerdo. Roseta de tecido nas cores branca, encarnada e verde cosida ao papel.

9. Conteúdo: o texto informa a data de nascimento da criança e que deve ser chamada de Julio Pedro Augusto. Relaciona os itens que a acompanham.

\section{ESCRITO 10}

1. Cota: Lisboa; Arquivo AH-SCML; Escritos dos expostos; Exposto no 815.

2. Datação: 1841.

3. Lugar de origem: Lisboa.

4. Reprodução da primeira linha: "Este infeliz innocente filho foe um Amor mutuo, e Sincero;".

5. Suporte material: papel sem pauta.

6. Composição: escrito manuscrito somente frente, formato quadrado; $A: 9 \mathrm{~cm} ; \mathrm{L}$ : $9 \mathrm{~cm}$.

7. Organização da página: folha avulsa, 7 linhas escritas.

8. Particularidades: originalmente este escrito fora entregue dobrado no meio, sendo que a mancha está na parte inferior da dobradura. Foram inseridos posteriormente na parte superior da folha o número do livro, o número da página e o número de registro. Não há assinatura no escrito.

9. Conteúdo: o texto informa data, hora e dia do nascimento da criança, que é o dia de Santo Anastácio. Informa ainda que seus progenitores pedem que seja carinhosamente tratada e que seja batizada com o nome de José. Informa ainda que os pais pretendem buscá-la. 


\section{ESCRITO 11}

1. Cota: Lisboa; Arquivo AH-SCML; Escritos dos expostos; Exposto $n^{\circ} 1247$.

2. Datação: 1842.

3. Lugar de origem: Lisboa.

4. Reprodução da primeira linha: "Esta menina Nasseo no dia 27 de julho".

5. Suporte material: papel sem pauta, cor azul.

6. Composição: escrito manuscrito somente frente, formato retangular; $A: 15 \mathrm{~cm}$; L: $10 \mathrm{~cm}$.

7. Organização da página: folha avulsa, 8 linhas escritas.

8. Particularidades: costurada ao escrito, há uma roseta de tecido feita em três camadas de tecidos a maior e inferior tem cor amarelada, a segunda rosa e a menor e superior verde. Entretanto, no escrito informa que a roseta tem uma de suas cores branca, provavelmente o tecido branco tenha se tornado amarelado pelo tempo. Não há assinatura.

9. Conteúdo: o texto informa a data e hora do nascimento da criança, que ela não está batizada, e solicita que seja chamada de Maria de Jezus. Faz referência a uma roseta branca, vermelha e verde que acompanha a criança. Relata que os pais pretendem procurá-la por meio do sinal que leva.

\section{ESCRITO 12}

1. Cota: Lisboa; Arquivo AH-SCML; Escritos dos Expostos.

2. Datação: 1843.

3. Lugar de origem: Lisboa.

4. Reprodução da primeira linha: "Illustrissimo Senhor esta criança".

5. Suporte material: papel sem pauta.

6. Composição: escrito manuscrito somente frente, formato retangular; $A: 9,5 \mathrm{~cm}$; $\mathrm{L}: 15 \mathrm{~cm}$.

7. Organização da página: folha avulsa, 5 linhas escritas.

8. Particularidades: desenho de moldura e rabiscos em cada um dos cantos e na parte central superior do papel. Não há assinatura.

9. Conteúdo: o texto informa data e hora do nascimento da criança e que deve ser chamada de Manoel dos Santos para ser batizada. Descreve o vestido que acompanha a criança. Informa que a criança "é para retirar".

\section{ESCRITO 13}

1. Cota: Lisboa; Arquivo AH-SCML; Escritos dos Expostos.

2. Datação: 1843.

3. Lugar de origem: Lisboa.

4. Reprodução da primeira linha: "Anno de 1843".

5. Suporte material: papel sem pauta, cor azul.

6. Composição: escrito manuscrito somente frente, formato retangular; $A: 18 \mathrm{~cm}$; L: $10 \mathrm{~cm}$.

7. Organização da página: folha avulsa, 7 linhas escritas.

8. Particularidades: pedaço de tecido branco costurado junto a escrito. Não há assinatura.

9. Conteúdo: O texto informa a data do nascimento da criança, e que seu nome é Joze Maria. Afirma ainda que a criança será procurada na Santa Casa. 


\section{ESCRITO 14}

1. Cota: Lisboa; Arquivo AH-SCML; Escritos dos expostos.

2. Datação: 1846.

3. Lugar de origem: Lisboa.

4. Reprodução da primeira linha: "Pede-se que aeste menino que".

5. Suporte material: papel sem pauta.

6. Composição: escrito manuscrito somente frente, formato retangular, L: $10 \mathrm{~cm} ; A$ : $5,5 \mathrm{~cm}$.

7. Organização da página: folha avulsa, 6 linhas escritas.

8. Particularidades: fitilho verde perpassado por dois pontos do lado esquerdo do escrito. Não há assinatura.

9. Conteúdo: O texto informa a data do nascimento da criança e que deve ser chamada de Joaquim. Afirma que seu pai irá procurá-la assim que possível.

\section{ESCRITO 15}

1. Cota: Lisboa; Arquivo AH-SCML; Escritos dos Expostos.

2. Datação: 1846.

3. Lugar de origem: Lisboa.

4. Reprodução da primeira linha: "1846".

5. Suporte material: papel sem pauta.

6. Composição: escrito manuscrito somente frente, formato retangular; lateral esquerda com um rabisco e cortada propositalmente de forma irregular.

7. Organização da página: folha avulsa, 6 linhas escritas.

8. Particularidades: recorte irregular do papel na parte esquerda e rabisco espiralado na margem esquerda. Há um alfinete perspassado horizontalmente, logo após a assinatura.

9. Conteúdo: o texto informa que a criança não está batizada e pede que seja registrada com o nome do [Santo] dia em que der entrada. Solicita que se guarde o escrito, pois ela será procurada.

\section{ESCRITO 16}

1. Cota: Lisboa; Arquivo AH-SCML; Escritos dos expostos.

2. Datação: 1886.

3. Lugar de origem: Lisboa.

4. Reprodução da primeira linha: "Este menino nasceu no dia 22 do mez".

5. Suporte material: papel sem pauta.

6. Composição: escrito manuscrito somente frente, formato retangular, $L: 13,5 \mathrm{~cm}$ x A: $13,5 \mathrm{~cm}$.

7. Organização da página: folha avulsa, 8 linhas escritas.

8. Particularidades: formato quadrado ao final da página duas iniciais como assinatura. Há assinatura.

9. Conteúdo: o texto informa data e hora de nascimento da criança e solicita seja chamada de Antonio. 


\section{ESCRITO 17}

1. Cota: Lisboa; Arquivo AH-SCML; Escritos dos expostos.

2. Datação: 1886.

3. Lugar de origem: Lisboa.

4. Reprodução da primeira linha: "Nasceu a 26 de Novembro as 3 -".

5. Suporte material: papel sem pauta.

6. Composição: escrito manuscrito somente frente, formato retangular; $A: 12,5 \mathrm{~cm}$; L: $7,5 \mathrm{~cm}$.

7. Organização da página: folha avulsa, 15 linhas escritas.

8. Particularidades: Não há assinatura.

9. Conteúdo: O texto informa data, hora e local de nascimento da criança. Informa também o local de batismo e que seu nome é Carlos. Relaciona o enxoval que acompanha a criança.

\section{ESCRITO 18}

1. Cota: Lisboa; Arquivo AH-SCML; Escritos dos expostos.

2. Datação: 1890.

3. Lugar de origem: Lisboa.

4. Reprodução da primeira linha: "Peço que à minha filha seja baptisada".

5. Suporte material: papel sem pauta.

6. Composição: escrito manuscrito somente frente, formato retangular; $A: 22 \mathrm{~cm}$; L: $30 \mathrm{~cm}$.

7. Organização da página: folha avulsa, 8 linhas escritas.

8. Particularidades: pedaço grande de tecido de cor verde claro, formato retangular, colado com gotas cera de cor verde escura, cera em excesso. Apresenta a assinatura de Marie Guilmain seguida da data.

9. Conteúdo: o texto informa data e hora de nascimento da criança, solicita que seja batizada com o nome de Carlota Bertha Maria José. Relaciona o enxoval que a acompanha.

\section{ESCRITO 19}

1. Cota: Lisboa; Arquivo AH-SCML; Escritos dos expostos.

2. Datação: 1892.

3. Lugar de origem: Lisboa.

4. Reprodução da primeira linha: "Nascêo a 26 de Janeiro".

5. Suporte material: papel sem pauta.

6. Composição: escrito manuscrito somente frente, formato retangular; $A: 28 \mathrm{~cm}$; L: $20 \mathrm{~cm}$.

7. Organização da página: folha avulsa, 15 linhas escritas.

8. Particularidades: junto ao escrito há a foto de um homem dentro de uma bolsinha de tecido. Não há assinatura. Fotografia e pedaço de tecido originalmente inseridos dentro do escrito dobrado.

9. Conteúdo: o texto informa data e hora de nascimento da criança e nome dos pais. Informa que a criança usa um vestido de cambraia branca. 


\section{ESCRITO 20}

1. Cota: Lisboa; Arquivo AH-SCML; Escritos dos expostos.

2. Datação: 1921.

3. Lugar de origem: Lisboa.

4. Reprodução da primeira linha: "Esta menina está".

5. Suporte material: papel sem pauta.

6. Composição: escrito manuscrito somente frente; formato retangular; $A: 7,5 \mathrm{~cm}$; L: $9 \mathrm{~cm}$.

7. Organização da página: folha avulsa, 5 linhas escritas.

8. Particularidades: não há assinatura.

9. Conteúdo: o texto informa que a criança está batizada, que seu nome é Maria Tereza Fernandes e que mais tarde virão vê-la. Solicita que guardem o escrito.

\section{ESCRITO 21}

1. Cota: Salvador; Arquivo CMJC-SCMBA; Escritos dos expostos.

2. Datação: 1959.

3. Lugar de origem: Salvador.

4. Reprodução da primeira linha: "José Bomfim Barbosa".

5. Suporte material: papel sem pauta, textura semelhante ao papel- cartão, cor amarela.

6. Composição: escrito manuscrito somente frente, formato retangular; $A: 15 \mathrm{~cm}$, L: $10,5 \mathrm{~cm}$.

7. Organização da página: folha avulsa, 10 linhas escritas.

8. Particularidades: não há assinatura. Texto telegráfico.

9. Conteúdo: o texto informa a data do nascimento da criança e que seu nome é José Bomfim Barbosa Nascimento. Indica o nome dos pais e o cartório em que foi registrado.

\section{ESCRITO 22}

1. Cota: Salvador; Arquivo CMJC-SCMBA; Escritos dos expostos.

2. Datação: 1960.

3. Lugar de origem: Salvador.

4. Reprodução da primeira linha: "Maria das Graças naceu no".

5. Suporte material: papel sem pauta.

6. Composição: escrito manuscrito somente frente, formato retangular, cortado propositalmente no canto superior esquerdo; A: 11,5cm; L: 19,5cm.

7. Organização da página: folha avulsa, 10 linhas escritas.

8. Particularidades: rasgos tardios no canto superior esquerdo e no canto inferior direito; não há assinatura.

9. Conteúdo: o texto informa a data e hora de nascimento da criança e que seu nome é Maria das Graças. Acrescenta que já está batizada e informa o nome dos pais. 


\section{ESCRITO 23}

1. Cota: Salvador; Arquivo CMJC-SCMBA; Escritos dos expostos.

2. Datação: 1961.

3. Lugar de origem: Salvador.

4. Reprodução da primeira linha: "Salvador 5-3-961".

5. Suporte material: papel sem pauta.

6. Composição: escrito manuscrito somente frente, formato retangular, A: 19; L: 20.

7. Organização da página: folha avulsa, 10 linhas escritas.

8. Particularidades: traçado irregular na segunda linha após término do texto; dobra como "orelha" no lado esquerdo do papel.

9. Conteúdo: o texto informa data e hora do nascimento da criança. Acrescenta que não está registrada, mas já está batizada e que seu nome é Wilson Ribeiro dos Santos.

\section{ESCRITO 24}

1. Cota: Salvador; Arquivo CMJC-SCMBA; Escritos dos expostos.

2. Datação: 1961.

3. Lugar de origem: Salvador.

4. Reprodução da primeira linha: "Isabel Cristina Marques".

5. Suporte material: papel sem pauta, textura semelhando ao papel- cartão, cor amarela.

6. Composição: escrito manuscrito somente frente, formato retangular, $A: 10 \mathrm{~cm}$; L: $16 \mathrm{~cm}$.

7. Organização da página: folha avulsa, 9 linhas escritas.

8. Particularidades: rasgos tardios nos cantos direito superior e esquerdo inferior do papel. Há algumas palavras e uma conta escrita na diagonal com outra tinta de caneta, em que se lê: " 1 ano 3 meses e 20 dias 31-18= 13 dias". Há assinatura legível: "Amalia Marques".

9. Conteúdo: o texto informa a data de nascimento da criança, que já está batizada e que seu nome é Isabel Cristina Marques.

\section{ESCRITO 25}

1. Cota: Salvador; Arquivo CMJC-SCMBA; Escritos dos expostos.

2. Datação: 1961.

3. Lugar de origem: Salvador.

4. Reprodução da primeira linha: "Salvador' 1 de Agosto de 1961'".

5. Suporte material: papel pautado.

6. Composição: escrito manuscrito somente frente, formato retângular, $A: 26 \mathrm{~cm}$; L: $20 \mathrm{~cm}$.

7. Organização da página: folha avulsa, 22 linhas escritas.

8. Particularidades: abaixo do texto há um registro de horário, grafado com outra tinta de caneta. Há recortes dentados na parte superior esquerda e na parte direita do papel.

9. Conteúdo: o texto informa data de nascimento da criança, que não está batizada, que se chama Dacj Silva e que será retirada quando completar 9 anos de idade. 


\section{ESCRITO 26}

1. Cota: Salvador; Arquivo CMJC-SCMBA; Escritos dos expostos.

2. Datação: 1969.

3. Lugar de origem: Salvador.

4. Reprodução da primeira linha: "Madre".

5. Suporte material: papel de seda sem pautas impressas.

6. Composição: escrito manuscrito somente frente, formato retangular; $A: 18 \mathrm{~cm}$; L: $12 \mathrm{~cm}$.

7. Organização da página: folha avulsa, 10 linhas escritas.

8. Particularidades: há assinatura legível: Julieta Viana. Orelha na parte superior do papel.

9. Conteúdo: O texto solicita que a criança seja entregue a quem puder recebêla.

\section{ESCRITO 27}

1. Cota: Rio de Janeiro; Arquivo ERD-SCMRJ; Escritos dos expostos.

2. Datação: 1858.

3. Lugar de origem: Rio de Janeiro.

4. Reprodução da primeira linha: "Remeto esta criança que nacio a 30 de Abril. de 1858 ".

5. Suporte material: papel sem pauta.

6. Composição: escrito manuscrito somente frente, formato triangular com recorte oblíquo irregular na margem direita, A: $21 \mathrm{~cm} ; \mathrm{L}: 19 \mathrm{~cm}$.

7. Organização da página: folha avulsa, 5 linhas escritas.

8. Particularidades: iniciais do nome do pai cortadas na diagonal.

9. Conteúdo: o texto informa a data de nascimento da criança e que deve ser chamada de Joaquim. Afirma também que será retirada e que nessa ocasião será apresentado como contrassinal a outra metade do escrito.

\section{ESCRITO 28}

1. Cota: Rio de Janeiro; Arquivo ERD-SCMRJ; Escritos dos expostos.

2. Datação: 1858.

3. Lugar de origem: Rio de Janeiro.

4. Reprodução da primeira linha: "A criança que este escrito accompanha".

5. Suporte material: papel sem pauta.

6. Composição: escrito manuscrito somente frente, formato retangular, $A: 24 \mathrm{~cm}$; L: $18 \mathrm{~cm}$.

7. Organização da página: folha avulsa, 5 linhas escritas.

8. Particularidades: o texto começa depois da metade do papel; o papel foi dobrado 3 vezes.

9. Conteúdo: o texto informa a hora e a data de nascimento da criança, que não está batizada e que deve ser chamada de Marianna. 


\section{ESCRITO 29}

1. Cota: Rio de Janeiro; Arquivo ERD-SCMRJ; Escritos dos expostos.

2. Datação: 1858.

3. Lugar de origem: Rio de Janeiro.

4. Reprodução da primeira linha: "Eu chamo-me Severina, est[ou] baptisada".

5. Suporte material: papel sem pauta.

6. Composição: escrito manuscrito somente frente, formato retangular, $A: 27 \mathrm{~cm}$; L: $20 \mathrm{~cm}$.

7. Organização da página: folha avulsa, 7 linhas escritas.

8. Particularidades: antecedendo o texto há desenho de um coração a inscrição "Eu chamo-me Severina" dentro dele, após o texto, iniciais M. R. A. J. P. escritas dentro de um coração duplo, e anotações ilegíveis na margem esquerda inferior.

9. Conteúdo: o texto informa que o nome da criança é Severina e que já está batizada. Afirma ainda que a mãe da criança está hospitalizada e que quando se restabelecer iria retirá-la.

\section{ESCRITO 30}

1. Cota: Rio de Janeiro; Arquivo ERD-SCMRJ; Escritos dos expostos.

2. Datação: 10 de abril 1858.

3. Lugar de origem: Rio de Janeiro.

4. Reprodução da primeira linha: "Esta innocente nasceu a 20 de Fevereiro do corrente an".

5. Suporte material: papel sem pauta.

6. Composição: escrito manuscrito somente frente, formato retangular, $A: 25 \mathrm{~cm}$; L: $20 \mathrm{~cm}$.

7. Organização da página: folha avulsa, 8 linhas escritas.

8. Particularidades: assinatura cortada por um recorte grande triangular na parte direita central do papel.

9. Conteúdo: o texto informa a data de nascimento da criança, que não está batizada e que seu nome deve ser Eleuteria. Solicita também que para vê-la ou retirá-la deverá ser apresentado como contrassinal a parte que falta no escrito.

1. Cota: Rio de Janeiro; Arquivo ERD-SCMRJ; Escritos dos expostos.

2. Datação: 26 de abril de 1858.

3. Lugar de origem: Rio de Janeiro.

4. Reprodução da primeira linha: "O menino está baptisado com o nome de Elias: hoje tem 23 dias".

5. Suporte material: papel sem pauta.

6. Composição: escrito manuscrito somente frente, formato retangular, $A: 20 \mathrm{~cm}$; L22cm.

7. Organização da página: folha avulsa, 7 linhas escritas.

8. Particularidades: não há assinatura.

9. Conteúdo: o escrito informa a data de nascimento da criança, que está batizada e que se chama Elias. Informa que talvez seja retirada por sua mãe adotiva. 


\section{ESCRITO 32}

1. Cota: Rio de Janeiro; Arquivo ERD-SCMRJ; Escritos dos expostos.

2. Datação: Maio de 1858.

3. Lugar de origem: Rio de Janeiro.

4. Reprodução da primeira linha: "Ilustrissimo Senhor".

5. Suporte material: papel sem pauta.

6. Composição: escrito manuscrito somente frente, formato retangular; $A: 28 \mathrm{~cm}$, L: $22,5 \mathrm{~cm}$.

7. Organização da página: folha avulsa, 14 linhas escritas.

8. Particularidades: -

9. Conteúdo: o texto informa que o nome da criança deve ser Antonio que deverá ser retirada mediante menção aos sinais que a acompanham.

\section{ESCRITO 33}

1. Cota: Rio de Janeiro; Arquivo ERD-SCMRJ; Escritos dos expostos.

2. Datação: 1 de julho de 1858.

3. Lugar de origem: Rio de Janeiro.

4. Reprodução da primeira linha: "Hoje 1 de julho de 1858".

5. Suporte material: papel sem pauta.

6. Composição: escrito manuscrito somente frente, formato retangular; $A: 21 \mathrm{~cm}$, L: $19 \mathrm{~cm}$.

7. Organização da página: folha avulsa, 5 linhas escritas.

8. Particularidades: não há assinatura.

9. Conteúdo: o texto solicita que a criança seja chamada de Idoardo e informa que será procurada. O escrito apresenta local e data da entrada da criança na roda.

\section{ESCRITO 34}

1. Cota: Rio de Janeiro; Arquivo ERD-SCMRJ; Escritos dos expostos.

2. Datação: 8 de Agosto de 1858.

3. Lugar de origem: Rio de Janeiro.

4. Reprodução da primeira linha: "Este innocente nasceu a 8 de Agosto".

5. Suporte material: papel sem pauta.

6. Composição: escrito manuscrito somente frente, formato retangular; $A: 27 \mathrm{~cm}$, L: $22,5 \mathrm{~cm}$.

7. Organização da página: folha avulsa, 20 linhas escritas.

8. Particularidades: não há assinatura.

9. Conteúdo: o texto informa a data de nascimento da criança, que não está batizada e que seu nome deve ser Joaquim Candido. Afirma que talvez seja retirada mediante menção aos sinais mencionados que a acompanham. 


\section{ESCRITO 35}

1. Cota: Rio de Janeiro; Arquivo ERD-SCMRJ; Escritos dos expostos.

2. Datação: 18 de Agosto de 1858.

3. Lugar de origem: Rio de Janeiro.

4. Reprodução da primeira linha: "Em nome do Altisemo Deos emtrego aminha filha".

5. Suporte material: papel sem pauta.

6. Composição: escrito manuscrito somente frente, formato retangular; $A: 19 \mathrm{~cm}$, $\mathrm{L}: 23 \mathrm{~cm}$.

7. Organização da página: folha avulsa, 9 linhas escritas.

8. Particularidades: há três iniciais como assinatura.

9. Conteúdo: o texto informa data e hora de nascimento da criança, que não está batizada e que seu nome deve ser Teresa. Relaciona os sinais que a acompanham e afirma que ela será retirada.

\section{ESCRITO 36}

1. Cota: Rio de Janeiro; Arquivo ERD-SCMRJ; Escritos dos expostos.

2. Datação: 20 de agosto de 1858.

3. Lugar de origem: Rio de Janeiro.

4. Reprodução da primeira linha: "Remeto este menino para su".

5. Suporte material: papel sem pauta.

6. Composição: escrito manuscrito somente frente, formato retangular; $A: 28 \mathrm{~cm}$, L: $20 \mathrm{~cm}$.

7. Organização da página: folha avulsa, 7 linhas escritas.

8. Particularidades: há três iniciais como assinatura.

9. Conteúdo: O texto informa que a criança deve ser chamada de Felicíssimo e que será retirada em um ano.

\section{ESCRITO 37}

1. Cota: Rio de Janeiro; Arquivo ERD-SCMRJ; Escritos dos expostos.

2. Datação: 4 de Setembro de 1858.

3. Lugar de origem: Rio de Janeiro.

4. Reprodução da primeira linha: "Rio de Janeiro 4 de Setembro de 1858 -“.

5. Suporte material: papel sem pauta.

6. Composição: escrito manuscrito somente frente, formato retangular; $A: 28 \mathrm{~cm}$, L: $21 \mathrm{~cm}$.

7. Organização da página: folha avulsa, 14 linhas escritas.

8. Particularidades: há três iniciais como assinatura.

9. Conteúdo: o texto informa que a criança deve ser chamada de Antonio e que será retirada, se estiver viva, mediante os sinais mencionados que a acompanham. 


\section{ESCRITO 38}

1. Cota: Rio de Janeiro; Arquivo ERD-SCMRJ; Escritos dos expostos.

2. Datação: 4 de Setembro de 1858.

3. Lugar de origem: Rio de Janeiro.

4. Reprodução da primeira linha: "Pedese ofavor que o [recem] presente seja".

5. Suporte material: papel sem pauta.

6. Composição: escrito manuscrito somente frente, na metade inferior do papel; formato retangular; A: $27 \mathrm{~cm}$, L: $20 \mathrm{~cm}$.

7. Organização da página: folha avulsa, 7 linhas escritas.

8. Particularidades: há duas iniciais como assinatura.

9. Conteúdo: o texto informa data e hora de nascimento da criança, que não está batizada e que seu nome deve ser Martinho da Rosa. Afirma que talvez seja retirada.

\section{ESCRITO 39}

1. Cota: Rio de Janeiro; Arquivo ERD-SCMRJ; Escritos dos expostos.

2. Datação: 2 de Novembro de 1858.

3. Lugar de origem: Rio de Janeiro.

4. Reprodução da primeira linha: "Ponderozos motivos obrigão a aban-“.

5. Suporte material: papel sem pauta.

6. Composição: escrito manuscrito somente frente, formato retangular; $A: 21 \mathrm{~cm}$, L: $22,5 \mathrm{~cm}$.

7. Organização da página: folha avulsa, 18 linhas escritas.

8. Particularidades: há quatro iniciais como assinatura.

9. Conteúdo: o texto informa a data de nascimento da criança, que não está batizada e que deve ser chamada de Isabel. Solicita que a criança sempre porte a medalha que a acompanha como sinal.

ESCRITO 40

1. Cota: Rio de Janeiro; Arquivo ERD-SCMRJ; Escritos dos expostos.

2. Datação: 2 de novembro 1858.

3. Lugar de origem: Rio de Janeiro.

4. Reprodução da primeira linha: "Roga-se a Illustrissima Administração".

5. Suporte material: papel sem pauta.

6. Composição: escrito manuscrito somente frente, formato retangular; $A: 20 \mathrm{~cm}$, $\mathrm{L}: 21 \mathrm{~cm}$.

7. Organização da página: folha avulsa, 9 linhas escritas.

8. Particularidades: não há assinatura.

9. Conteúdo: o texto informa data de nascimento da criança e que ela deve ser chamada de Victorio. Informa ainda que será retirada mediante entrega de cópia do escrito. 


\section{ESCRITO 41}

1. Cota: Rio de Janeiro; Arquivo ERD-SCMRJ; Escritos dos expostos.

2. Datação: 17 de Dezembro 1858.

3. Lugar de origem: Rio de Janeiro.

4. Reprodução da primeira linha: “[Humenaije] pedida!".

5. Suporte material: papel sem pauta.

6. Composição: escrito manuscrito somente frente, formato retangular; $A: 27 \mathrm{~cm}$, L: $19 \mathrm{~cm}$.

7. Organização da página: folha avulsa, 10 linhas escritas.

8. Particularidades: há assinatura.

9. Conteúdo: o texto informa que a criança não está batizada e que deve ser chamada Luduvina Pereira dos Prazeres. Afirma ainda que deve permanecer com os sinais com ela deixados.

\section{ESCRITO 42}

1. Cota: Rio de Janeiro; Arquivo ERD-SCMRJ; Escritos dos expostos.

2. Datação: 31 de Dezembro de 1858.

3. Lugar de origem: Rio de Janeiro.

4. Reprodução da primeira linha: "Rio de Janeiro 31 de Dezembro de 1858."

5. Suporte material: papel pautado.

6. Composição: escrito manuscrito somente frente, formato retangular; $A: 26 \mathrm{~cm}$, L: $19 \mathrm{~cm}$.

7. Organização da página: folha avulsa, 9 linhas escritas.

8. Particularidades: após o texto há o número 494, registrado tardiamente com outra caneta. Tem como assinatura as palavras: "O incógnito". Recorte no canto direito superior do papel.

9. Conteúdo: O texto informa data e hora do nascimento da criança, que não está batizada e que deve ser chamada de Josefa. Afirma ainda que será retirada.

\section{ESCRITO 43}

1. Cota: Rio de Janeiro; Arquivo ERD-SCMRJ; Escritos dos expostos.

2. Datação: 1 março 1880 .

3. Lugar de origem: Rio de Janeiro.

4. Reprodução da primeira linha: "Esta menina naçeo no dia".

5. Suporte material: papel pautado.

6. Composição: escrito manuscrito somente frente, formato retangular; $A: 19 \mathrm{~cm}$, L: $21 \mathrm{~cm}$.

7. Organização da página: folha avulsa, 8 linhas escritas.

8. Particularidades: escrito acompanha sinal: uma fita azul marinho colada horizontalmente abaixo do texto. Não há assinatura.

9. Conteúdo: O texto informa data e local de nascimento da criança, que não está batizada, e que seu nome deve ser Adelina. Informa ainda que leva como sinal uma fita azul marinho. 


\section{ESCRITO 44}

1. Cota: Rio de Janeiro; Arquivo ERD-SCMRJ; Escritos dos expostos.

2. Datação: 14 de Janeiro de 1880.

3. Lugar de origem: Rio de Janeiro.

4. Reprodução da primeira linha: "Dia 14 de Janeiro de 1880." .

5. Suporte material: papel sem pauta.

6. Composição: escrito manuscrito somente frente, formato retangular; $A: 29 \mathrm{~cm}$, L: $17 \mathrm{~cm}$.

7. Organização da página: folha avulsa, 14 linhas escritas.

8. Particularidades: há como assinatura as palvras: "Sua criada".

9. Conteúdo: o texto informa data e hora de nascimento da criança, que não está batizada e que seu nome deve ser Hilário. Afirma ainda que seu irmão foi entregue à roda dois anos antes.

\section{ESCRITO 45}

1. Cota: Rio de Janeiro; Arquivo ERD-SCMRJ; Escritos dos expostos.

2. Datação: 1880.

3. Lugar de origem: Rio de Janeiro.

4. Reprodução da primeira linha: "Esta criança nasceu no".

5. Suporte material: papel sem pauta.

6. Composição: escrito manuscrito somente frente, formato retangular; $A: 20 \mathrm{~cm}$, L: $21 \mathrm{~cm}$.

7. Organização da página: folha avulsa, 6 linhas escritas.

8. Particularidades: não há assinatura.

9. Conteúdo: o texto informa a data de nascimento da criança e que deve ser chamada de Maria. Solicita que guardem o escrito, pois será retirada mediante a menção do mesmo.

\section{ESCRITO 46}

1. Cota: Rio de Janeiro; Arquivo ERD-SCMRJ; Escritos dos expostos.

2. Datação: 1880.

3. Lugar de origem: Rio de Janeiro.

4. Reprodução da primeira linha: "Não é o crime que aqui expõe".

5. Suporte material: papel, com pautas feitas à mão.

6. Composição: escrito manuscrito frente e verso, formato retangular; com um dos cantos arredondados semelhante a uma etiqueta, com um ilhó A: $5 \mathrm{~cm}$, L: 10,5cm.

7. Organização da página: folha avulsa, 5 linhas escritas na frente da folha e 5 linhas escritas no verso.

8. Particularidades: escrito em versos; o formato do suporte da escrita é de uma etiqueta. Não há assinatura. Alfinete perspassado ao escrito.

9. Conteúdo: o texto informa a data de nascimento da criança e que seu nome deve ser Deodato. 


\section{ESCRITO 47}

1. Cota: Rio de Janeiro; Arquivo ERD-SCMRJ; Escritos dos expostos.

2. Datação: 1880.

3. Lugar de origem: Rio de Janeiro.

4. Reprodução da primeira linha: "Ja está registrado.".

5. Suporte material: papel pautado.

6. Composição: escrito manuscrito somente frente, formato quadrado com os cantos superiores arredondados; A: $10 \mathrm{~cm}, \mathrm{~L}: 11 \mathrm{~cm}$.

7. Organização da página: folha avulsa, 7 linhas escritas.

8. Particularidades: inscrito no verso, outra caneta: "42728|Alfredo|Escrito N. 1" . Como assinatura, há duas as iniciais intercaladas por sustenido: "B \# B".

9. Conteúdo: O texto informa que a criança foi registrada, mas que não está batizada e que se chama Alfredo.

\section{ESCRITO 48}

1. Cota: Rio de Janeiro; Arquivo ERD-SCMRJ; Escritos dos expostos.

2. Datação: 22 de Junho 1901.

3. Lugar de origem: Rio de Janeiro.

4. Reprodução da primeira linha: "Senhoras da Caridade".

5. Suporte material: papel pautado.

6. Composição: escrito manuscrito somente frente, formato retangular; recorte tardio no canto superior esquerdo; A: $24 \mathrm{~cm}$, L: $20 \mathrm{~cm}$.

7. Organização da página: folha avulsa, 12 linhas escritas.

8. Particularidades: há duas iniciais como assinatura.

9. Conteúdo: o texto informa data e hora do nascimento da criança e solicita que ela seja marcada com as iniciais "E.C.

\section{ESCRITO 49}

1. Cota: Rio de Janeiro; Arquivo ERD-SCMRJ; Escritos dos expostos.

2. Datação: 1903.

3. Lugar de origem: Rio de Janeiro.

4. Reprodução da primeira linha: "Esta creança é filha de pais incognitos; não está baptisada; deve chamar-se".

5. Suporte material: papel sem pauta.

6. Composição: escrito manuscrito somente frente, em formato de tira; $A: 1,5 \mathrm{~cm}$, L: $15 \mathrm{~cm}$.

7. Organização da página: folha avulsa, 3 linhas escritas.

8. Particularidades: escrito em formato muito pequeno e estreito. Não há assinatura. No verso há a inscrição tardia com o número e nome do exposto.

9. Conteúdo: o texto informa a data de nascimento da criança e que deve ser chamada de João. Afirma que será retirada mediante apresentação de cópia do escrito e do pedaço que falta na medalha que acompanha a criança. 


\section{ESCRITO 50}

1. Cota: Rio de Janeiro; Arquivo ERD-SCMRJ; Escritos dos expostos.

2. Datação: 5 de Dezembro de 1903.

3. Lugar de origem: Rio de Janeiro.

4. Reprodução da primeira linha: "Rio de Janeiro 5 de Dezembro de 1903".

5. Suporte material: papel sem pauta.

6. Composição: escrito manuscrito somente frente, formato retangular; $A: 24 \mathrm{~cm}$, L: $19 \mathrm{~cm}$.

7. Organização da página: folha avulsa, 16 linhas escritas.

8. Particularidades: recorte quadrado com bordas irregulares no centro do escrito. Não há assinatura.

9. Conteúdo: o texto informa que o nome da criança é José e que se possível ela será retirada.

\section{ESCRITO 51}

1. Cota: Rio de Janeiro; Arquivo ERD-SCMRJ; Escritos dos expostos.

2. Datação: 27 de Junho de 1955.

3. Lugar de origem: Rio de Janeiro.

4. Reprodução da primeira linha: "Deicho esta criança para ser dada".

4. Suporte material: papel sem pauta.

5. Composição: escrito manuscrito somente frente, formato quadrado; $A: 12 \mathrm{~cm}$, L: $19 \mathrm{~cm}$.

6. Organização da página: folha avulsa, 6 linhas escritas.

7. Particularidades: no topo do escrito há a anotação tardia do número do exposto. Há uma assinatura legível.

8. Conteúdo: o escrito informa a data de nascimento da criança, que ela não está batizada, nem registrada e que pode ser dada.

ESCRITO 52

1. Cota: São Paulo; Arquivo MSC-SP; Escritos dos expostos.

2. Datação: 25 de Outubro 1917.

3. Lugar de origem: São Paulo.

4. Reprodução da primeira linha: "S. Paulo, 25 de Outubro de 1917".

5. Suporte material: papel sem pauta.

6. Composição: escrito manuscrito somente frente, formato retangular; $A: 10 \mathrm{~cm}$, $\mathrm{L}: 13 \mathrm{~cm}$.

7. Organização da página: folha avulsa, 8 linhas escritas.

8. Particularidades: não há assinatura. Dobra em forma de "orelha" na parte superior direita.

9. Conteúdo: o escrito informa que a criança já foi batizada, que se chama Vicente e que se for possível será retirada. 


\section{ESCRITO 53}

1. Cota: São Paulo; Arquivo MSC-SP; Escritos dos expostos.

2. Datação: 7 de Outubro 1920.

3. Lugar de origem: São Paulo.

4. Reprodução da primeira linha: "Carlos Penna".

5. Suporte material: papel sem pauta.

6. Composição: escrito manuscrito somente frente, formato retangular; $A: 24 \mathrm{~cm}$, L: $19 \mathrm{~cm}$.

7. Organização da página: folha avulsa, 10 linhas escritas.

8. Particularidades: não há assinatura.

9. Conteúdo: o texto informa a data de nascimento da criança e que já está batizada. Solicita se conserve como relíquia a medalha da Virgem da Conceição no pescoço da criança, como cumprimento de uma promessa.

1. Cota: São Paulo; Arquivo MSC-SP; Escritos dos expostos.

2. Datação: 14 de Dezembro 1921.

3. Lugar de origem: São Paulo.

4. Reprodução da primeira linha: "Esta criança cha-".

5. Suporte material: papel pautado.

6. Composição: escrito manuscrito somente frente, formato retangular; $A: 13 \mathrm{~cm}$, L: $12 \mathrm{~cm}$.

7. Organização da página: folha avulsa, 9 linhas escritas.

8. Particularidades: há assinatura legível.

9. Conteúdo: o texto informa data de nascimento da criança, que não está batizada e que seu nome é Isabel de Jesus.

\section{ESCRITO 55}

1. Cota: São Paulo; Arquivo MSC-SP; Escritos dos expostos.

2. Datação: 1922.

3. Lugar de origem: São Paulo.

4. Reprodução da primeira linha: "Saõ Paulo 21-2-1922 | Dor de mãe".

5. Suporte material: papel pautado.

6. Composição: escrito manuscrito somente frente, formato retangular; $A$ : $22 \mathrm{~cm}, \mathrm{~L}: 17 \mathrm{~cm}$.

7. Organização da página: folha avulsa, 19 linhas escritas na frente da folha e 21 linhas escritas no verso.

8. Particularidades: há uma escrita no cabeçalho do folha em diagonal, apresenta carimbo do Museu da SCMSP. O texto é organizado em forma de poema. Não há assinatura. As duas folhas que compõem esse escrito estão totalmente amassadas.

9. Conteúdo: o texto informa que se for possível a criança será retirada. Solicita que a criança seja entregue apenas a quem apresentar cópia do escrito. 


\section{ESCRITO 56}

1. Cota: São Paulo; Arquivo MSC-SP; Escritos dos expostos.

2. Datação: 30 de Maio de 1922.

3. Lugar de origem: São Paulo.

4. Reprodução da primeira linha: "São Paulo 30 de Maio de 1922."

5. Suporte material: papel pautado.

6. Composição: escrito manuscrito somente frente, formato retangular; $A: 10 \mathrm{~cm}$, L: $13 \mathrm{~cm}$.

7. Organização da página: folha avulsa, 10 linhas escritas.

8. Particularidades: não há assinatura.

9. Conteúdo: o texto informa a data de nascimento da criança, que foi registrada com o nome de Olevia de S. Lima, e que seu apelido é Gloria.

\section{ESCRITO 57}

1. Cota: São Paulo; Arquivo MSC-SP; Escritos dos expostos.

2. Datação: 27 de Junho de 1922.

3. Lugar de origem: São Paulo.

4. Reprodução da primeira linha: "Recebam-me".

5. Suporte material: papel com impressões de página de livro caixa.

6. Composição: escrito manuscrito frente e verso, formato retangular; $A: 24 \mathrm{~cm}, L$ : $20 \mathrm{~cm}$.

7. Organização da página: folha avulsa, 17 linhas escritas na frente da folha e 14 no verso.

8. Particularidades: redigido em folha de livro caixa (deveres/haveres). Ao final do escrito há o número de registro do exposto, redigido por outro punho e instrumento de escrita. Não há assinatura.

9. Conteúdo: o texto informa que o nome da criança é Antonio Moreira de Carvalho. Informa também que é órfã de pai, que sua mãe se chama Angélica e que algum dia iria retirá-la.

\section{ESCRITO 58}

1. Cota: São Paulo; Arquivo MSC-SP; Escritos dos expostos.

2. Datação: 1922.

3. Lugar de origem: São Paulo.

4. Reprodução da primeira linha: "Ainda não está".

5. Suporte material: papel de seda, sem pautas impressas.

6. Composição: escrito manuscrito somente frente, formato retangular pequeno; A: $5 \mathrm{~cm}, \mathrm{~L}: 10 \mathrm{~cm}$.

7. Organização da página: folha avulsa, 4 linhas escritas.

8. Particularidades: o escrito foi entregue uma foto e um santinho do Sagrado Coração de Jesus. Não há assinatura.

9. Conteúdo: o texto informa que a criança não está batizada e solicita que tenha por padrinho o Sagrado Coração de Jesus. 


\section{ESCRITO 59}

1. Cota: São Paulo; Arquivo MSC-SP; Escritos dos expostos.

2. Datação: 1923.

3. Lugar de origem: São Paulo.

4. Reprodução da primeira linha: "Irmã Superiora".

5. Suporte material: papel pautado.

6. Composição: escrito manuscrito frente e verso, formato retangular; $A: 13 \mathrm{~cm}$, $\mathrm{L}: 12 \mathrm{~cm}$.

7. Organização da página: folha avulsa, 18 linhas escritas na frente e 16 no verso.

8. Particularidades: escrito digirido à Irmã Superiora por alguém que parecia a conhecer. Como assinatura há a palavra: Serva. Orelha no canto superior direito, rasgo accidental tardio no canto inferior esquerdo.

9. Conteúdo: o texto informa a data de nascimento da criança, que não está batizada e que seu nome deve ser Maria Helena. Solicita ainda que não retirem a medalha que acompanha a criança e que ela será reclamada dentro de um ano.

ESCRITO 60

1. Cota: São Paulo; Arquivo MSC-SP; Escritos dos expostos.

2. Datação: 4 de Outubro 1923.

3. Lugar de origem: São Paulo.

4. Reprodução da primeira linha: "São Paulo, 4-10-923".

5. Suporte material: papel pautado.

6. Composição: escrito manuscrito somente frente, formato retangular; $A: 15 \mathrm{~cm}$, L: $21 \mathrm{~cm}$.

7. Organização da página: folha avulsa, 15 linhas escritas.

8. Particularidades: não há assinatura.

9. Conteúdo: o texto faz apenas uma referência à criança, pedindo compaixão por ela, e explana sobre a situação de miséria da mãe.

Diferente de outras espécies textuais, a transcrição da primeira linha de cada escrito revela sua irregularidade de estrutura redacional.

A inserção inicial das datas tópicas ou cronológicas ao início não representa regra, mas ocorre nos escritos $9,13,15,23,25,33,37,42,44,50,54,56$ e 60. Em raros casos, há o vocativo, como nos escritos 12, 26, 32, 48 e 59.

Dada a sucinta extensão do texto, via de regra, inicia-se a escrita com menção diretamente ao assunto do que se quer comunicar. Destaca-se o escrito 46, em que o texto resume já na primeira linha sua intenção principal de justificar-se: "Não é o crime que aqui expõe". Cabe mencionar também o escrito 29, em que o emprego da primeira pessoa indica que o autor seria a própria criança, que logo revela a principal preocupação moral coeva: "Eu chamo-me Severina, est[ou] baptisada”. 



\section{ANÁLISE FILOLÓGICA DOS ESCRITOS}

Para este estudo, consideramos a clássica explicação de Segismundo Spina na qual define que a atividade filológica desempenha três funções inter-relacionadas:

$1^{\text {a) }}$ Função substantiva, em que ela se concentra no texto para explica-lo, restituí-lo à sua forma genuína e prepara-lo tecnicamente para publicação; $2^{a}$ ) Função adjetiva, em que ela deduz o texto, aquilo que não está nele: a determinação de autoria, a biografia do autor, a datação do texto, a sua posição na produção literária do autor e da época, bem como a sua avaliação estética (valorização); $3^{\mathrm{a}}$ ) Função transcendente, em que o texto deixa de ser um fim em si mesmo da tarefa filológica, para se transformar num instrumento que permite ao filólogo reconstituir a vida espiritual de um povo ou de uma comunidade em determinada época (SPINA, 1977, p. 77).

As funções substantiva, adjetiva e transcendente explicadas acima não são examinadas isoladamente neste este estudo pois estão ligadas umas às outras.

As características formais do documento são determinadas pelas circunstâncias de sua elaboração, pelo grau de cultura daqueles que os redigem, pelos meios de que dispõem para elaborá-los e pelo teor daquilo que necessitam registrar (TESSIER, 1952, p.14). Tendo isto em vista, procederemos uma análise diplomática dos escritos da roda. Considerando que a crítica diplomática parte da forma do documento para o ato iniciado ou referido pelo documento. Portanto, o procedimento explicitado por Duranti $(1989$, p.13) é valioso para explicar nossa abordagem dos escritos da roda. "A análise tem por objetivo compreender o contexto jurídico e administrativo no qual os documentos que estão sendo examinados foram criados" e "reflete uma progressão sistemática do específico para o geral"86,87. Como ensina Tessier (1952, p.12-13), a Diplomática é a disciplina que se se ocupa da descrição e explicação da estrutura formal dos atos escritos ${ }^{88}$.

\footnotetext{
86 "this analysys aims at understanding the juridical,, administrative (...) context in which the documents under examination were created" (...) and reflects a systematic progression from the specific to the general".

${ }^{87}$ Nosso pressuposto é de que os escritos das Rodas, apesar de não serem documentos que passavam por uma chancelaria ou que tivessem um modelo a ser seguido, podem ser considerados atos jurídicos (o que caracteriza um doc. diplomático), pois são uma forma de transmitir a vontade do autor (seja material ou intelectual) e de transferir os direitos e responsabilidades dos progenitores ou responsáveis pela criança para a Roda dos Expostos.

${ }^{88}$ Nous dirons donc que l'objet de la diplomatique est la description et l'explication de la forme des actes écrits. Elle ne se contentara pas d'un simple relevé, mais s'appliquera à rendre raison de toutes les modifications intervenues dans les caractères des actes et déterminées par les circonstances de leur élaboration, par la qualité du personnel chargé de les rédiger et de les écrire, par les modèles que rédacteurs et écrivains pouvaient avoir sous les yeux, par la nature des dispositions qu'il s'agissait de
} 
A análise será feita por meio do estudo dos elementos extrínsecos e intrínsecos dos escritos do corpus.

\subsection{ELEMENTOS EXTRÍNSECOS}

Elementos extrínsecos de um documento são aqueles que constituem sua composição material e sua aparência externa (DURANTI, 1991, p. 6).

A autora sumariza, conforme abaixo os elementos extrínsecos da forma documental ${ }^{89}$ :

Meio $\left\{\begin{array}{l}\text { Material } \\ \text { Formato } \\ \text { Preparação para o recebimento da mensagem }\end{array}\right.$

Escrito $\left\{\begin{array}{l}\text { Layout }^{90}, \text { paginação, formatação } \\ \text { Tipos de escrita } \\ \text { Diferentes punhos, tipos de letra e tipos de tinta } \\ \text { Paragrafação } \\ \text { Pontuação } \\ \text { Abreviaturas e iniciais } \\ \text { Erros e correções } \\ \text { Softwares de computador } \\ \text { Fórmulas }\end{array}\right.$

Linguagem $\quad\left\{\begin{array}{l}\text { Vocabulário } \\ \text { Composição } \\ \text { Estilo }\end{array}\right.$

Sinais especiais $\left\{\begin{array}{l}\text { Sinais dos autores e redatores } \\ \text { Sinais de chancelaria e registros oficiais. }\end{array}\right.$

Os elementos extrínsecos de nosso corpus que analisaremos serão a composição do suporte material e seu formato, os elementos anexados ao suporte, e

consigner et à parler en général par le degré de culture du milieu dans lequel les actes ont été élaborés, en sorte que la production diplomatique d'une société est dans une certaine mesure le reflet de sa civilisation (Tessier, 1952, p.13).

${ }^{89}$ Esquema adaptado de Duranti (1991, p. 6).

${ }^{90}$ Termo utilizado por Duranti $(1991$, p. 6). 
os acréscimos ao texto. Cada um desses elementos será explicado e examinado a seguir.

\subsubsection{Composição do suporte}

O primeiro elemento extrínseco a se considerar é o meio, isto é, o material que carrega a mensagem. Tradicionalmente, identificar a composição do suporte da escrita era essencial para que os diplomatistas pudessem datar, estabelecer a proveniência e testar a autenticidade dos manuscritos. No entanto, com o passar do tempo, muito dessa relevância perdeu-se com o advento da manufatura de papel e com a diversidade de material à disposição. Estabelecemos como suporte padrão de nossos manuscritos o papel branco ou amarelado pela ação do tempo, liso e sem pauta, pois constituem a maioria dos escritos estudados. A seguir, apresentaremos um quadro com os escritos que apresentam variação desse padrão.

Quadro 6 - Variação na composição do suporte de escrita

\begin{tabular}{|l|l|}
\hline Escrito & Descrição dos suportes materiais dos escritos - varição do padrão \\
\hline Escrito 4 & Papel azul claro sem pauta (textura semelhante ao papel vergê) \\
\hline Escrito 11 & Papel azul claro sem pauta (textura semelhante ao papel vergê) \\
\hline Escrito 13 & Papel azul claro sem pauta (textura semelhante ao papel vergê) \\
\hline Escrito 14 & Papel branco pautado \\
\hline Escrito 16 & Papel branco pautado \\
\hline Escrito 15 & Papel branco pautado \\
\hline Escrito 19 & Papel branco pautado \\
\hline Escrito 20 & Papel branco pautado \\
\hline Escrito 21 & Papel amarelo sem pauta (espesso, liso, semelhante a papel-cartão) \\
\hline Escrito 22 & Papel branco pautado \\
\hline Escrito 23 & Papel branco pautado \\
\hline Escrito 24 & Papel amarelo sem pauta (espesso, liso, semelhante a papel-cartão) \\
\hline Escrito 25 & Papel branco pautado \\
\hline Escrito 26 & Papel branco sem pauta de seda \\
\hline Escrito 42 & Papel branco pautado \\
\hline Escrito 43 & Papel branco pautado \\
\hline Escrito 45 & Papel branco pautado \\
\hline Escrito 46 & Papel amarelo pautado (pauta feitaà mão) \\
\hline Escrito 47 & Papel branco pautado \\
\hline Escrito 48 & Papel branco pautado \\
\hline Escrito 53 & Papel branco pautado \\
\hline Escrito 54 & Papel branco pautado \\
\hline Escrito 55 & Papel branco pautado \\
\hline Escrito 56 & Papel branco pautado \\
\hline Escrito 57 & Papel branco pautado (folha de livro-caixa) \\
\hline Escrito 58 & Papel branco sem pauta de seda \\
\hline Escrito 59 & Papel branco pautado \\
\hline Escrito 60 & Papel branco pautado \\
\hline & \\
\hline
\end{tabular}


Pelo levantamento apresentado acima, notamos que a diversidade da composição do suporte da escrita comprova-se, quer pelo advento da manufatura que possibilita a produção de papéis já com pautas e diferentes cores e texturas, quer por escolha deliberada por parte do autor do escrito, como ocorre na utilização da folha de livro-caixa (escrito 57), ou de um pedaço de papel de seda (escrito 58) ou de um papel com pautas inseridas à mão (escrito 46).

Podemos verificar também que as variações na composição do suporte relacionam-se com a data cronológica do escrito. Quanto mais recentes forem os escritos, maior será a variedade de suportes. Esse fenômeno pode ser verificado no gráfico $^{91}$ abaixo:

Gráfico 2 - Variação da composição do suporte de escrita

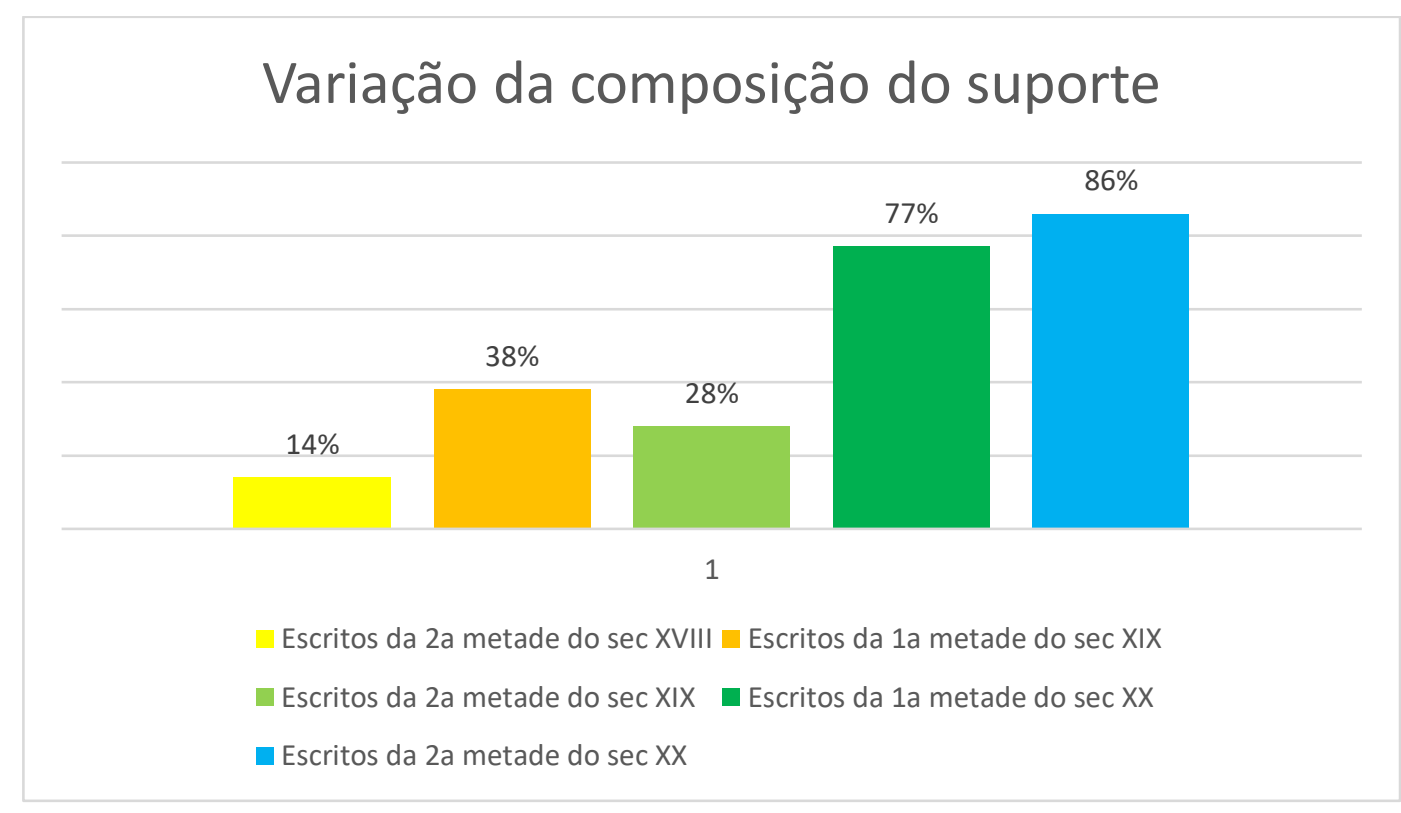

Na segunda metade do século XVIII, observamos que apenas 14\% dos escritos analisados apresentam variação na composição do suporte. Na primeira metade do século XIX, 38\% dos escritos analisados apresentam variação do suporte. Na segunda metade do século XIX essa variação é de $28 \%$. No século XX, a proporção dos escritos que apresenta variação do suporte aumenta substancialmente, atingindo $77 \%$ na primeira metade do século e $86 \%$ na segunda metade do século.

\footnotetext{
${ }^{91}$ Com o objetivo de avaliar características específicas dos escritos da Roda, realizaremos algumas estatísticas relacionadas a cada meio século. Estas estatísticas consideram 100\% o total de escritos de cada meio século, para extrair o percentual relativo a cada característica analisada.
} 


\subsubsection{Formato do suporte}

Durante nossa pesquisa, consultamos, aproximadamente, oitocentos manuscritos da roda, o que nos permite afirmar que o formato retangular ou quadrado é o que predomina nos escritos da roda. Portanto, consideramos que o formato padrão de nosso corpus é retangular ou quadrado.

A análise desse aspecto é relevante, uma vez que as variações no suporte podem ter sido elaboradas de forma intencional pelo autor do escrito, para caracterizar um sinal. Isto é, o autor pode optar por executar alterações no formato do suporte o de seu escrito para torná-lo único, diferenciando-o de qualquer outro escrito que desse entrada na roda.

A seguir, os dados do quadro relacionam os escritos com variação do formato padrão.

Quadro 7 - Variação do formato do suporte de escrita

\begin{tabular}{|l|l|}
\hline Escrito & Descrição dos diferentes formatos dos escritos \\
\hline Escrito 3 & Recorte irregular do papel na margem inferior \\
\hline Escrito 4 & Suporte em formato triangular, recorte oblíquo com uma saliência na parte central \\
\hline Escrito 5 & Recorte irregular do papel na margem inferior \\
\hline Escrito 7 & Recorte irregular do papel na margem esquerda \\
\hline Escrito 8 & Recorte irregular do papel na margem inferior \\
\hline Escrito 14 & Suporte com formato retangular de pequena dimensão \\
\hline Escrito 15 & Recorte irregular do papel na margem esquerda92 \\
\hline Escrito 25 & Recortes dentados do papel na margem superior esquerda e na margem direita \\
\hline Escrito 27 & Suporte em formato triangular, recorte oblíquo irregular em uma das margens \\
\hline Escrito 30 & Recorte grande em forma de triângulo na margem direita do papel \\
\hline Escrito 42 & Recorte na margem direita superior \\
\hline Escrito 46 & $\begin{array}{l}\text { Suporte com formato de pequeno retângulo com um dos lados arredondado, } \\
\text { semelhante a uma etiqueta }\end{array}$ \\
\hline Escrito 47 & Formato quadrado com as margens superiores arredondados \\
\hline Escrito 49 & Suporte em formato de tira \\
\hline Escrito 50 & Recorte quadrado com bordas irregulares na parte central do escrito \\
\hline Escrito 58 & Suporte com formato retangular de pequena dimensão \\
\hline
\end{tabular}

Observa-se que um número significativo de escritos do corpus apresenta variações no formato (16 escritos de um total de 60, ou seja, 27\%).

92 Esse tipo de recorte nos remete ao corte dentado em documento do século XIII. V.: http://academia.gal/destaque-documento/-/asset_publisher/d4TP/content/carta-partida. 
Entre as variações mais frequentes, estão aquelas relacionadas a recortes nas bordas do papel, seja nos lados ou nas margens superiores ou inferiores. A maior parte dos recortes apresenta formas sinuosas, enquanto alguns poucos mostram linhas angulosas. O escrito 30 apresenta um recorte grande em forma de triângulo na parte direita do papel, o que sugere uma produção intencional por parte do autor do escrito. O escrito 50 apresenta recorte quadrado com bordas irregulares na parte central do escrito, o que the confere grande singularidade. Tal característica nos sugere ter sido produzida intencionalmente pelo autor do escrito.

Outra variação que constatamos foi a presença de escritos com uma forma ou dimensão não usual. O escrito 49 , por exemplo, apresenta um suporte de pequenas de dimensões, correspondendo a uma tira de papel horizontal. As três linhas do texto preenchem todo o espaço do papel, sem margens superiores nem laterais. $O$ escrito 58, embora tenha a forma padrão retangular, apresenta tamanho reduzido. Outros formatos não usuais podem ser exemplificados pelos escritos 4, 27, e 47. O escrito 4 apresenta suporte formato triangular com recorte oblíquo com uma saliência na parte central. O escrito 27 apresenta formato triangular com recorte oblíquo irregular em uma das margens e o escrito 47, por sua vez, apresenta formato quadrado com os cantos superiores arredondados. $\mathrm{O}$ escrito 46 merece um comentário a parte, pois apresenta o suporte no formato de um pequeno retângulo com um dos lados arredondado, correspondente a uma etiqueta. Esta característica particular será analisada, posteriormente, em conjunto com outros elementos diplomáticos.

Verificamos que a variação no formato do suporte está relacionada ao período de sua produção. A seguir, o gráfico explicita esta variação. 
Gráfico 3 - Variação do formato do suporte de escrita

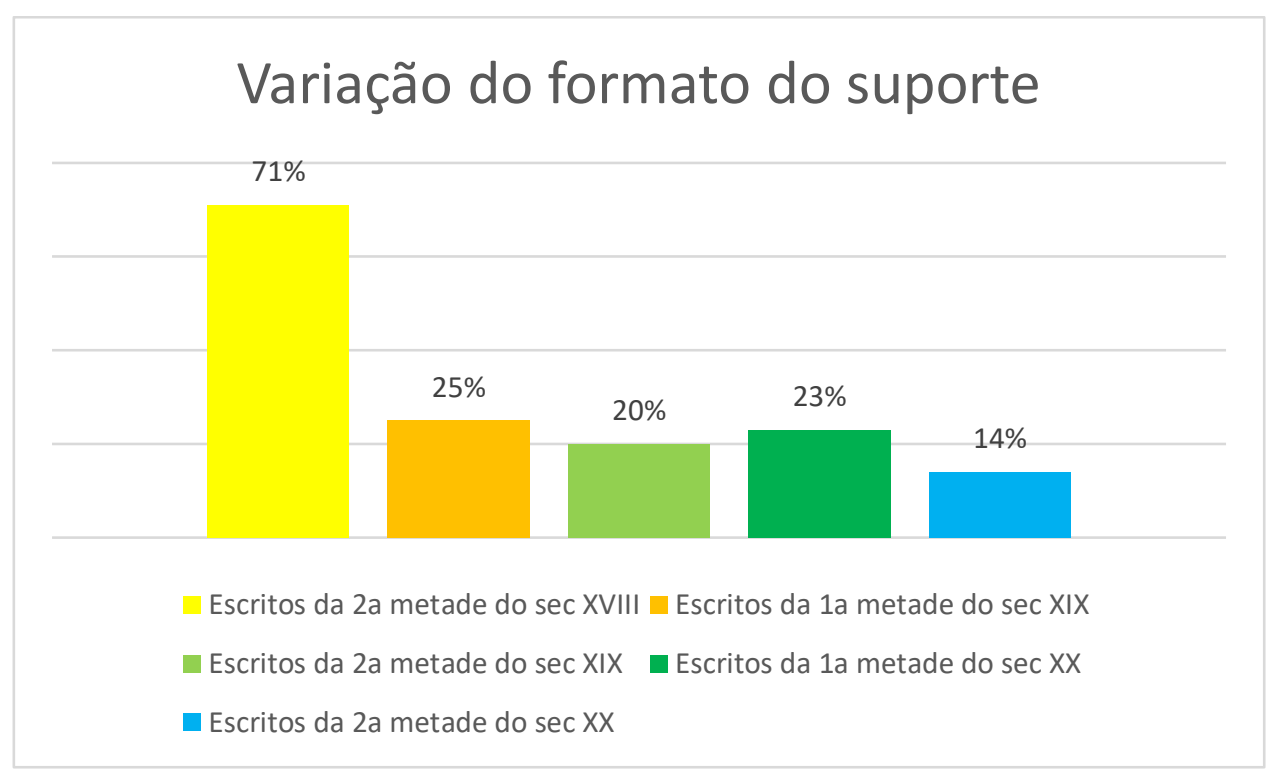

Nota-se que, na segunda metade do século XVIII, mais de $70 \%$ dos escritos coletados apresentam variação no formato do suporte e que, nos séculos seguintes, esta porcentagem foi caindo de maneira constante. Na primeira parte do século XIX, apenas um quarto dos escritos coletados apresentou esta característica e, na segunda metade do século XIX, esta proporção caiu para um quinto dos escritos coletados. $\mathrm{Na}$ primeira metade do século $X X$, tal proporção praticamente manteve-se, para cair a um sétimo nas décadas seguintes. Nossa hipótese é que as variações no formato do suporte tenham relação com a intenção do autor de produzir sinais. As mudanças no contexto histórico de funcionamento das rodas e da necessidade de preservar o anonimato dos responsáveis pela criança reflete-se na produção documental. A produção de sinais é mais abundante quanto mais estrito for o funcionamento das rodas, isto é, conforme a legislação passa a exigir a identificação da pessoa que expõe a criança.

\subsubsection{Elementos anexados ao suporte: Sinais}

O estudo dos elementos extrínsecos é importante para melhor compreensão dos escritos da roda, pois oferece recursos para entender como os sinais são compostos: alguns sinais configuram-se por elementos materiais que são anexados ao suporte da escrita por meio de costuras, colagens ou de inserções de diferentes tipos como de uma tira de fita perpassada ao papel ou mesmo um ilhó no papel. 
Uma característica específica dos elementos extrínsecos é sua ligação com os documentos originais. Suas características, via de regra, não se transmitem à reprodução. Este fato é importante quando analisamos os escritos seguintes, em que "o fac-símile e a transcrição tentam reproduzir o original, porém o fazem de forma imperfeita" (TESSIER, 1952, p. 30).

A seguir, um quadro com os escritos que contêm elementos anexados ao suporte.

Quadro 8 - Descrição dos elementos anexados ao suporte de escrita

\begin{tabular}{|l|l|}
\hline Escrito & Descrição dos elementos anexados ao suporte \\
\hline Escrito 5 & Fita cor de rosa perpassada verticalmente no suporte \\
\hline Escrito 6 & Fita de seda perpassada horizontamente no suporte \\
\hline Escrito 11 & Roseta branca, encarnada e verde, cosida ao suporte \\
\hline Escrito 14 & Fitilho verde perpassado em dois pontos na margem esquerda do suporte \\
\hline Escrito 15 & Alfinete perpassado horizontalmente no final da mancha após a assinatura \\
\hline Escrito 18 & Pedaço grande de tecido retangular azul claro colado com gotas de cera \\
\hline Escrito 19 & Fotografia e pedaço de tecido inseridos no escrito dobrado \\
\hline Escrito 43 & Fita azul marinho colada horizontalmente no papel, abaixo da mancha \\
\hline Escrito 46 & Ilhó inserido no papel \\
\hline
\end{tabular}

A prática de inserir, colar ou costurar material e objetos nos escritos da roda como sinais é descrita por alguns estudiosos. Manoel (2006, p. 79) refere que "parte destes escritos eram acompanhados por uma fita ou um pedaço de tecido; mais raramente surgiam outro tipo de acessórios, tais como um retrato do progenitor". Em nosso corpus, nove escritos apresentaram essa característica.

O manuseio e o contato visual com os manuscritos originais foi de grande valia para a análise desses exemplares. Agruparemos tais sinais levando em conta o modo como estão anexados ao suporte. Os sinais podem estar perpassados, colados, cosidos ou aplicados ao suporte, bem como inseridos no suporte dobrado.

Nos escritos 5 e 6 , foi observada a presença de fitas perpassadas ao texto. 0 exame do manuscrito original do escrito 6 - em que uma fita de seda aparece perpassada horizontamente no suporte, encobrindo de modo parcial o texto - permitiunos conhecer o teor do texto encoberto pela fita. O escrito 15 apresenta um objeto metálico anexado ao suporte da mesma forma, após a assinatura do autor. O exame do original tornou possível identificar um alfinete. No escrito 14, um fitilho longo está 
perpassado ao suporte no lado esquerdo do papel, o que sugere que sua existência seja intencional e tenha uma função, provavelmente, a de apensar o escrito à alguma peça de roupa ou mesmo à criança.

Os escritos 43 e 18 apresentam, respectivamente, uma fita e um pedaço de tecido colados ao suporte. No segundo caso o tecido foi colado com gotas de cera, o que provocou manchas que ficaram impregnadas no papel.

O escrito 11 por sua vez apresenta uma roseta cosida ao suporte.

O escrito 46 apresenta um objeto metálico aplicado ao suporte que identificamos como um ilhó. Assim como o escrito 14, observamos intenção de sua existência. Neste caso, a função de apensar o escrito à alguma peça de roupa ou mesmo à criança é mais clara, especialmente se levarmos em conta o formato desse documento que já analisamos anteriormente e que lembra uma etiqueta.

No escrito 19, os acessórios que podem servir de sinal - a fotografia e o pedaço de tecido - estavam originalmente dentro das dobras do escrito ${ }^{93}$.

O quadro abaixo apresenta os tipos de sinais anexados ao suporte.

Quadro 9 - Tipos de sinais anexados ao suporte

Tipos de sinais anexados ao suporte

Tipo 1 - Objetos perpassados ao suporte (fita, fitilho, alfinete)

Tipo 2 - Objetos colados ao suporte (fita, pedaço de tecido)

Tipo 3 - Objeto cosido ao suporte (roseta)

Tipo 4 - Objeto aplicado ao suporte (ilhó)

Tipo 5 - Objetos dentro do escrito dobrado (fotografia, pedaço de tecido)

\footnotetext{
${ }^{93}$ Para realizar o fac-símile do escrito foi necessário desdobrá-lo, assim nos foi possível encontrar a foto e o pedaço de tecido.
} 
Sua distribuição cronológica está evidenciada no gráfico abaixo:

Gráfico 4 - Elementos anexados ao suporte de escrita

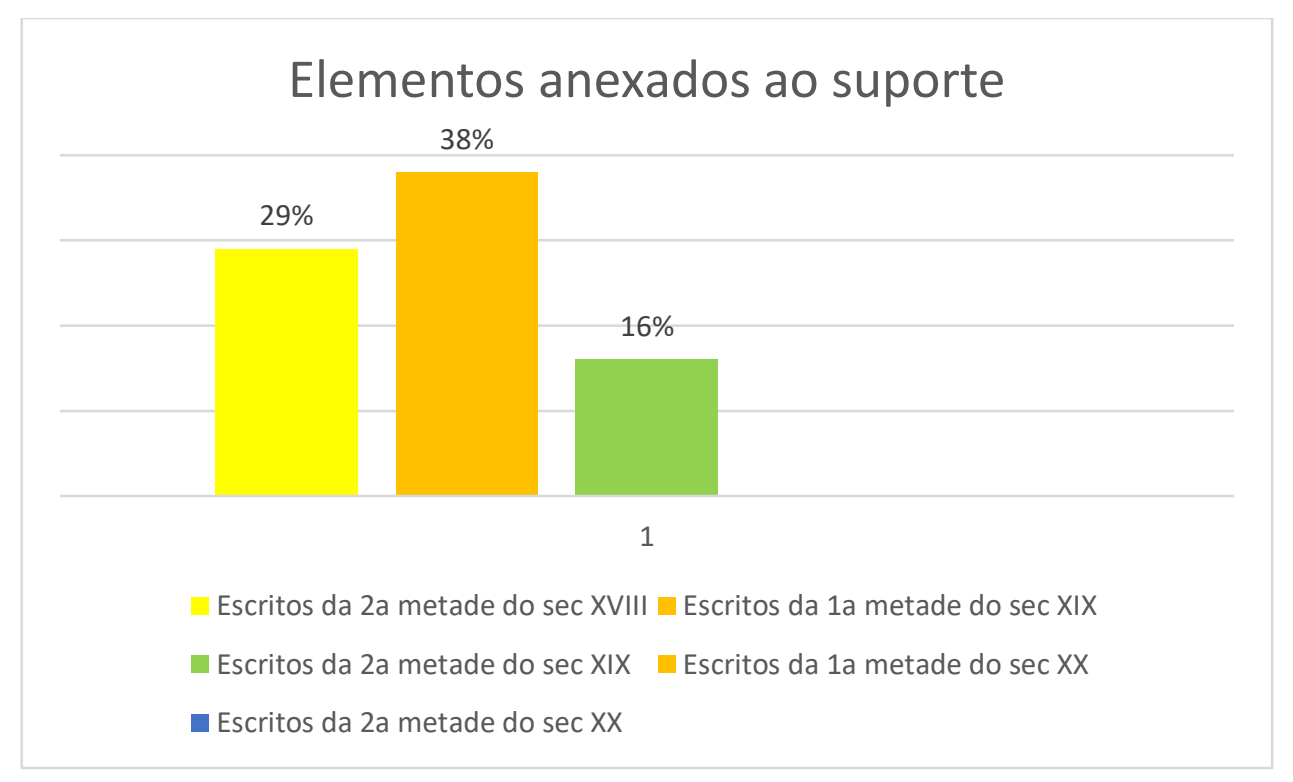

Observamos uma incidência significativa da anexação de elementos nos escritos da segunda metade do século XVIII e da primeira metade do século XIX, abarcando $29 \%$ e $38 \%$ dos escritos, respectivamente. Uma pequena porcentagem de escritos da segunda metade do século XIX também apresenta elementos anexados ao suporte. É digna de nota a ausência de ocorrências no século XX. Os dados indicam que a presença de sinais anexados ao suporte está relacionada às alterações no contexto histórico de funcionamento das rodas e à necessidade de preservar o anonimado dos responsáveis pela criança, que foi se extinguindo gradativamente. 


\subsubsection{Acréscimos ao texto}

O que denominamos "acréscimos ao texto" são aqueles elementos que estão fora da mancha do texto. Descreveremos os tipos de acréscimos ao texto encontrados em nosso corpus.

Quadro 10 - Descrição dos acréscimos ao texto encontrados no corpus

\begin{tabular}{|l|l|}
\hline Escrito & Descrição dos acréscimos a o texto \\
\hline Escrito 7 & Hastes e desenhos de flores na margem esquerda do texto \\
\hline Escrito 12 & Traçados em torno das margens, nos cantos e na parte central superior do papel \\
\hline Escrito 15 & Traçado espiralado na margem esquerda do texto \\
\hline Escrito 29 & $\begin{array}{l}\text { Desenho de coração na margem superior com texto inserido e desenho de coração } \\
\text { duplo na margem inferior com iniciais inseridas }\end{array}$ \\
\hline
\end{tabular}

Destacamos o escrito 29 em que dentro do desenho de coração, na margem superior, há a inscrição "eu chamo-me Severina" e dentro do coração duplo, na margem inferior, encontramos as iniciais M. R. e A. J. P., supostamente, dos progenitores da criança. Os dados do quadro abaixo apresentam os tipos de acréscimos ao texto.

Quadro 11 - Tipos dos acréscimos ao texto encontrados no corpus

Tipo 1 - Desenhos

Tipo 2 - Traçados 
Em relação à ocorrência de acréscimos ao texto por período, podemos observar o gráfico abaixo:

Gráfico 5 - Presença de acréscimos ao texto no corpus

\section{Acréscimos ao texto}

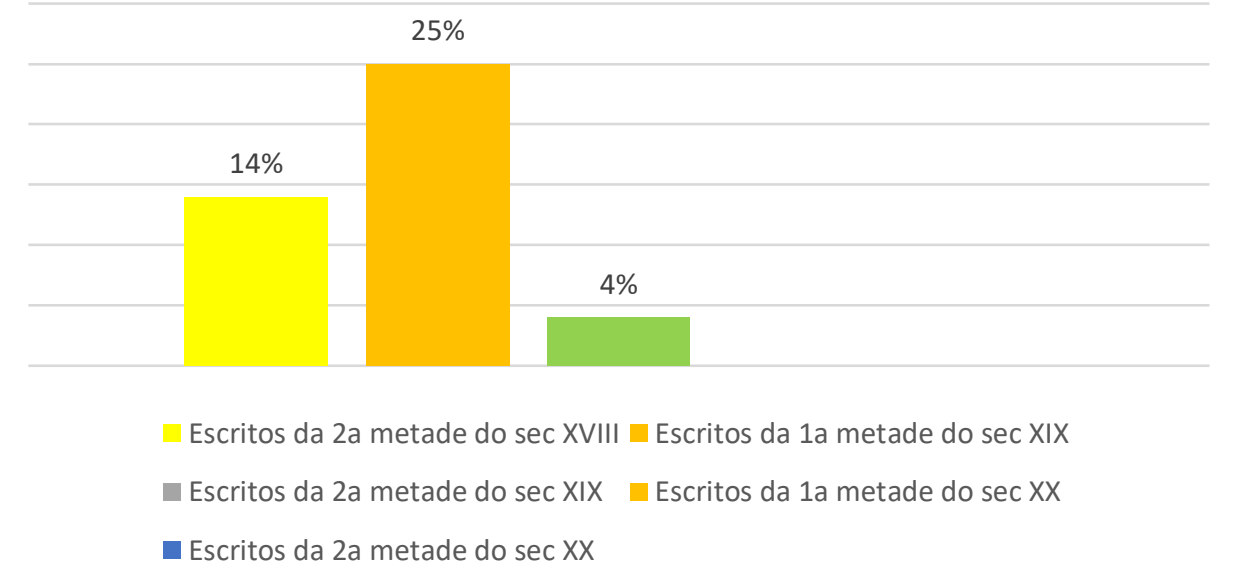

A primeira metade século XIX apresentou maior incidência de escritos com acréscimos ao texto, seguida pela segunda metade do século XVIII. Nota-se que, na segunda metade do século XIX, o número de ocorrências passou a ser insignificante e que, no século $X X$, não houve nenhum registro da prática de produzir acréscimos ao texto. O que podemos concluir é que a presença desses sinais também está relacionada à condição de anonimato e ao desejo do autor de individualizar o escrito.

Após esta breve análise diplomática dos elementos extrínsecos dos escritos do corpus, procederemos à análise diplomática dos elementos intrínsecos dos manuscritos.

\subsection{ELEMENTOS INTRÍNSECOS}

Os elementos intrínsecos de um documento são os componentes que integram sua articulação intelectual, ou a forma como o conteúdo se apresenta (DURANTI, 1991, p. 11). Cabe lembrar ainda que, para estudar as características internas ou intrínsecas dos atos, não é necessário um original ou um fac-símile, sendo suficiente apenas uma cópia fiel manuscrita ou impressa, conforme a lição de Tessier (1952, p. 30). 
Bellotto (2002, 38-41) ensina que os documentos diplomáticos são compostos por três partes fundamentais: protocolo inicial, texto e protocolo final. A autora assim descreve em linhas gerais as partes de um documento:

O protocolo inicial ou protocolo, na seqüência dos dados, é constituído por: 1) invocação (invocatio) que, em geral, só ocorre nos atos dispositivos mais antigos (a expressão "Em nome de Deus" é um exemplo de invocação); 2) titulação (intitulatio), formada pelo nome próprio da autoridade (soberana ou delegada) de que emana o ato e por seus títulos; 3) direção ou endereço (inscriptio), parte que nomeia a quem o ato se dirige, seja um destinatário individual ou coletivo e 4) saudação (salutatio), parte final do protocolo.

O texto, que tem "todos os seus elementos comandados pela natureza jurídica do ato e por seu objetivo" (TESSIER, 1961)

O protocolo final ou escatocolo inicia-se após a corroboração ou cláusulas finais, com: 1) subscrição/assinatura (subscriptio), isto é, a assinatura do emissor/autor do documento ou quem o faça por sua ordem; 2) datação (datatio). É preciso distinguir a data tópica da data cronológica, ou o elemento topográfico do elemento cronológico. A primeira é referente à forma como está designado no documento o local onde ele foi assinado. A segunda corresponde ao dia, mês e ano; 3) precação (apprecatio), onde, por meio de dois elementos (assinatura de testemunhas e sinais de validação, como carimbos e selos), reitera-se a legalidade do documento (BELLOTO, 2002, p. 38-41).

\subsubsection{Protocolo inicial dos escritos da roda}

Iniciaremos nossa análise diplomática examinando o protocolo inicial dos escritos da roda. O protocolo inicial consiste da invocação (invocatio); da titulação (intitulatio), da direção ou endereçamento (inscriptio) e da saudação (salutatio), que é a parte final do protocolo, conforme ensinamento de Bellotto. Sabemos, porém, que nem todos os elementos aparecem em um mesmo documento.

Poucos escritos apresentam as partes do protocolo referentes à invocação. Encontramos exemplos nos escritos 23 ("pelo amor de Deus") e 35 ("Em nome do Altisemo Deos"). Nenhum escrito possui referência à titulação, uma vez que esta parte do protocolo é "formada pelo nome próprio da autoridade de que emana o ato e por seus títulos". Não sendo o ato de depositar a criança na roda chancelado ou regulamentado, o escrito que o registra, evidentemente, não fará referência a alguma autoridade ou a seus títulos. Alguns escritos contêm em seu protocolo inicial uma saudação. Podemos mencionar o escrito 26 ("Boa tarde"). 
Entre os elementos que constituem o protocolo inicial, procedemos à análise da direção ou endereço (inscriptio) que é a parte que nomeia a quem o ato se dirige, seja um destinatário individual ou coletivo (BELLOTTO, 2002, p. 38).

As rodas dos expostos, as casas do expostos e as instituições que acolhiam os enjeitados eram bastante conhecidas dos depositantes. Entretanto, como o depósito da criança era efetuado de forma anônima, impessoal e sem testemunhas, tanto as pessoas que depositavam como as que recebiam as crianças não tinham suas identidades reveladas. Verificamos que o destinatário é desconhecido do autor do escrito, o que faz com que a maior parte dos escritos (49 de um total de 60) não apresente um destinatário explícito.

Quando o autor do escrito dirige-se a alguém, o que ocorre em 11 escritos, são utilizados diferentes recursos para configurar um destinatário. Entre estas estratégias, estão o uso de um destinatário coletivo ou de destinatários indeterminados. O autor pode dirigir-se a um destinatário coletivo, representado pela instituição. É o que ocorre nos escritos 1 ("Para a Casa da Santa Misericórdia"), 34 (a esta "Casa Pia/Santa Casa") e 40 ("Ilustríssima Administração deste Asilo"). Encontramos escritos que se dirigem a pessoas que fazem parte de uma instituição, sem nomeá-las. É o caso dos escritos 48 (“Senhoras da Caridade”), 50 (“Excelentíssimas Irmãs”) e 60 ("Digníssimas Irmãs").

Há escritos cujo destinatário é um indivíduo, nomeado por seu título institucional. É o que ocorre nos escritos 26 ("Madre"), 44 ("Senhora Regente") e 59 ("Irmã Superiora”). Há autores de escritos que também se dirigem a indivíduos, porém utilizam-se de pronomes de tratamento, sem nomeá-los. É o que ocorre nos escritos 12 e 32, ambos têm como destinatário "Ilustríssimo Senhor".

Abaixo, apresentamos os dados do quadro-resumo com as marcas de identificação do destinatário do escrito. 
Quadro 12 - Marcas de identificação do destinatário encontradas no corpus

\begin{tabular}{|l|l|}
\hline Identificação do destinatário & \multicolumn{1}{c|}{ Exemplos do corpus } \\
\hline Instituição como destinatária & $\begin{array}{l}\text { Escrito 1: Casa da Santa Misericórdia } \\
\text { Escrito 34: Casa Pia/Santa Casa }\end{array}$ \\
& Escrito 40: Ilustríssima Administração deste Asilo \\
\hline $\begin{array}{l}\text { Grupo de pessoas pertencentes a uma } \\
\text { instituição }\end{array}$ & $\begin{array}{l}\text { Escrito 48: Senhoras da Caridade } \\
\text { Escrito 50: Excelentíssimas Irmãs }\end{array}$ \\
\hline Indivíduo pertencente a uma instituição & Escrito 60: Digníssimas Irmãs \\
\hline $\begin{array}{l}\text { Indivíduo indicado pelo pronome de } \\
\text { tratamento }\end{array}$ & $\begin{array}{l}\text { Escrito 44: Senhora Regente } \\
\text { Escrito 59: Irmã Superiora }\end{array}$ \\
\hline
\end{tabular}

A seguir, no gráfico observamos a distribuição dos escritos do corpus que contêm marcas de identificação do destinatário.

Gráfico 6 - Marcas de identificação de destinatário no corpus

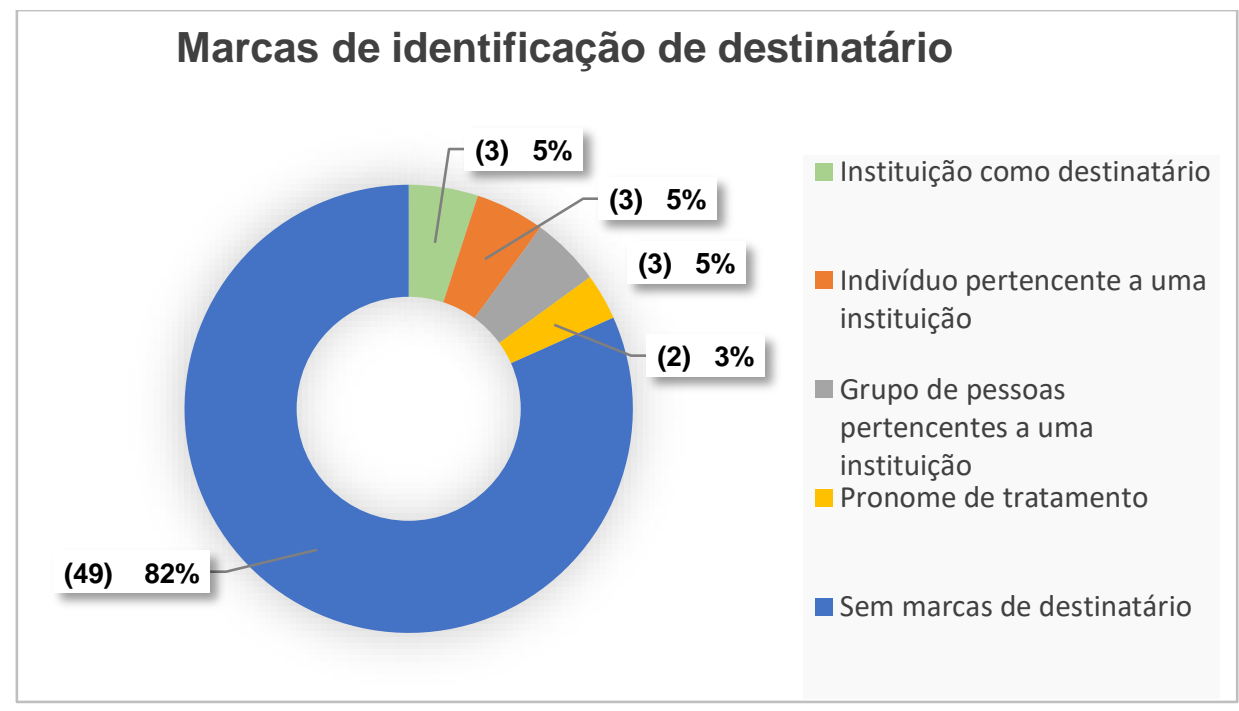

Verificamos que $82 \%$ dos escritos não apresentam marcas de identificação do destinatário, o que nos leva a inferir que os autores dos escritos desconhecem os destinatários de seus escritos. O anonimato da roda não se restringe apenas à identidade do depositante da criança, mas também daquele que recebe a criança. Os escritos que apresentam marcas de identificação do destinatário (18\%), dirigem-se a destinatários impessoais: 15\% referem-se à instituição ou a funções dentro da instituição que acolhe os expostos e penas 3\% das marcas de identificação do destinatário estão desvinculadas do contexto institucional. 
Uma vez examinado os elementos do protocolo inicial dos escritos da roda, procederemos ao estudo dos elementos do protocolo final.

\subsubsection{Protocolo final: identificação do autor}

O protocolo final dos escritos ou escatocolo apresenta a subscriptio, que é a assinatura do autor do escrito e a datatio, que pode ser a datação local ou cronológica.

Iniciamos nossa análise pelo estudo das assinaturas. A prática da exposição de crianças na roda era anônima ${ }^{94}$ e, em sua grande maioria, os escritos não apresentam explicitamente o nome ou a assinatura do autor. Quando o fazem, trazem assinaturas ou rubricas indecifráveis ou apenas iniciais, o que torna praticamente impossível a identificação da autoria, uma vez que não havia documentação ou registro relativo à origem da criança, a não ser o escrito ou os sinais e os objetos e roupas que a acompanhavam.

Encontramos em nosso corpus vários escritos assinados, porém as assinaturas ou rubricas são indecifráveis. É o caso dos escritos 4, 5, 9, 15, 30 e 41. No escrito 30, a assinatura está cortada, e tem uma parte faltante ${ }^{95}$.

Em alguns escritos, o autor identifica-se apenas pelas iniciais, como no escrito 35 (“A.B.L."), no escrito 38 (“R..G”), no escrito 39 (“M. Y. da S.P.”), no escrito 48 ("E.C.") e no escrito 59 (C.). No escrito 36, as iniciais do remetente "B.C.S." vêm acompanhadas de uma assinatura ilegível na linha abaixo. No escrito 37, além das iniciais "C. A. C.”, pode-se visualizar um nome (Maria) junto à margem esquerda.

No escrito 27, as iniciais do autor encontram-se incompletas, pois estão cortadas. Seriam conhecidas caso fosse encontrada a parte faltante do escrito.

Há escritos em que o nome da autora aparece com clareza e completo, como nos escritos 18 ("Marie Guilman"), 24 ("Amalia Marques"), 26 (“Julieta Viana") e 51 ("Jacinta dos Santos"). Devemos ressaltar, nesses casos, que os escritos datam de um período em que o anonimato na entrega das crianças não é mais possível, dada a mudança na legislação referente ao abandono de menores. O mesmo ocorre nos

\footnotetext{
${ }^{94}$ A partir de 1870 (extinção da Roda de Lisboa), em Portugal, e 1927 (Proibição do Sistema de Rodas pelo Código de Menores), no Brasil, a expoisção anômina foi sendo cada vez menos frequente. Não obstante, algumas Rodas ainda continuaram funcionando e muitas crianças ainda foram depositadas anonimamente.

${ }^{95}$ Esses escritos nos remetem à tradição medieval de separar um documento em duas partes. V.: http://academia.gal/destaque-documento/-/asset_publisher/d4TP/content/carta-partida).
} 
escritos 50 ("Cassianna") e 54 ("Dulce"), que trazem explicitamente o prenome da autora.

Há escritos em que a identificação do autor é realizada de outras formas, sem o uso de uma assinatura ou subscrição. Nesses casos, o autor do escrito vale-se de desenhos ou recursos, como a utilização de perífrases. Apresentamos a seguir alguns exemplos destes procedimentos.

No escrito 47, uma espécie de desenho aparece entre duas letras maiúsculas, conforme podemos observar na reprodução a seguir.

Figura 19 - Escrito 47 - Identificação de autoria

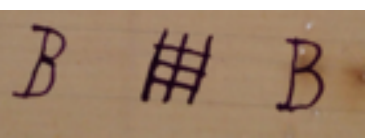

No escrito 60, observamos que o autor não se identifica com clareza, utilizando uma perífrase à guisa de subscrição ("Sem mais recebam cumprimentos de um pai e mãe que se veem aflitos"). O autor do escrito 42 torna explícito seu desejo de ocultarse. Subscreve-se como "O Incógnito". O mesmo ocorre no escrito 44, em que a autora identifica-se como "Sua criada".

O quadro-resumo apresenta a seguir as idenficações de autoria presentes em nosso corpus.

Quadro 13 - Marcas de identificação do autor encontradas no corpus

\begin{tabular}{|l|l|}
\hline Identificação do autor & \multicolumn{1}{|c|}{ Exemplos do corpus } \\
\hline Assinatura ou rubrica indecifrável & Escritos 4, 5, 9, 15, 41 \\
\hline Assinatura ou rubrica com parte faltante & Escrito 30 \\
\hline Iniciais & Escrito 35: A.B.L. \\
& Escrito 38: R..G \\
& Escrito 39: M. Y. da S.P. \\
& Escrito 48: E.C. \\
& Escrito 36: B.C.S. \\
& Escrito 37: C. A. C. \\
& Escrito 59: C. \\
\hline Iniciais com parte faltante & Escrito 27 \\
\hline Prenome & Escritos 50: Cassiana \\
& Escrito 54: Dulce \\
\hline Nome completo & Escritos 18: Marie Guilman \\
& Escritos 24: Amalia Marques \\
& Escritos 26: Julieta Viana \\
& Escritos 51: Jacinta dos Santos \\
\hline
\end{tabular}

Realizando uma análise comparativa entre os escritos, verificamos que a utilização de diferentes formas de subscrição está relacionada à data cronológica do 
escrito, o que pode ser observado nos gráficos referentes à distribuição cronológica das diferentes formas de subscrição: assinaturas ou rubricas, iniciais e nomes.

O gráfico abaixo mostra a distribuição cronológica da utilização de assinatura para a identificação de autoria.

Gráfico 7 - Utilização de assinatura para identificar o autor Identificação do autor: ASSINATURA

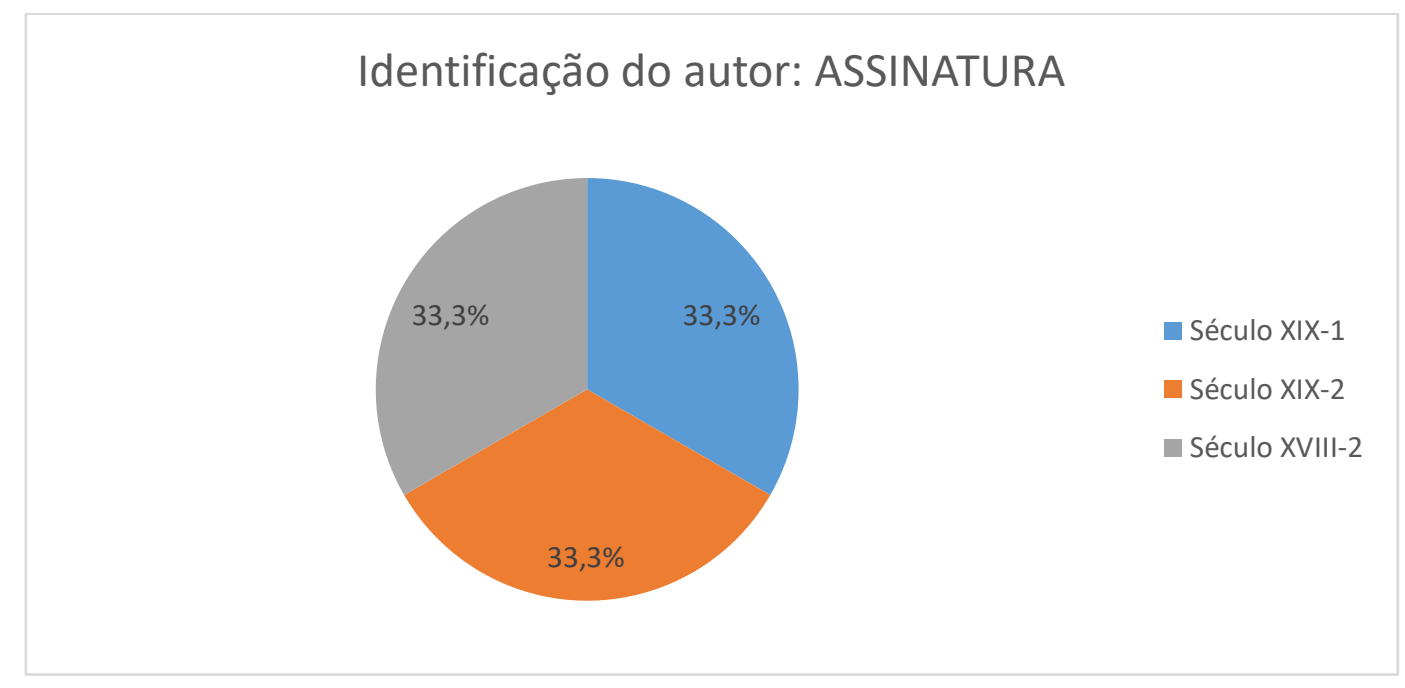

Verificamos que a utilização de assinaturas está restrita aos séculos XVIII e XIX, sendo igualmente distribuída entre a segunda metade do século XVIII, a primeira e a segunda metades do século XIX. É digno de nota o fato de não haver nenhuma ocorrência de assinaturas no século XX. 
No gráfico seguinte, será apresentada a utilização de iniciais para identificação de autoria.

Gráfico 8 - Utilização de iniciais para identificar o autor Identificação do autor: INICIAIS

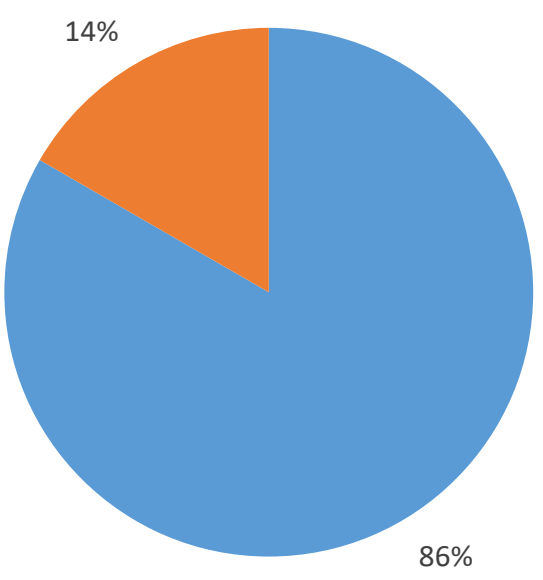

- Século XIX-2

- Século XX-1

O uso de iniciais para identificar a autoria concentra-se, preferencialmente, na segunda metade do século XIX (86\%), havendo também algumas ocorrências na primeira metade do século XX (14\%). É digno de nota não haver nenhuma ocorrência de uso de iniciais na segunda metade do século XVIII e na primeira metade do século XIX. No próximo gráfico, observamos a utilização do nome para identificação de autoria. 
Gráfico 9 - Utilização do nome para identificar o autor

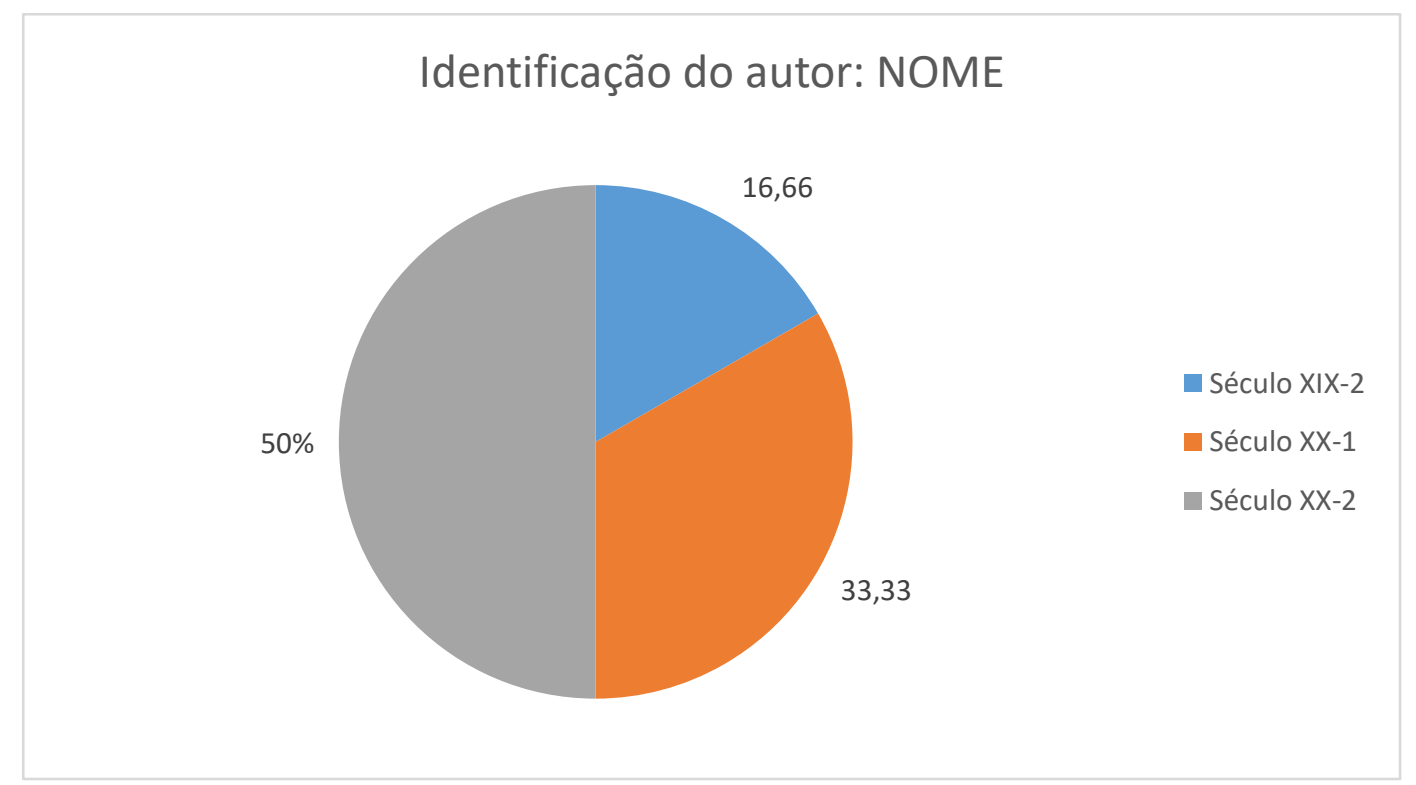

O gráfico revela que o uso do nome do autor, seja o prenome ou o nome completo do autor, só é empregada a partir da segunda metade do século XIX e sua prevalência aumenta quanto mais recente for o escrito. $O$ fato pode ser explicado pela gradual proibição do anonimato no depósito dos expostos nas rodas.

Os estudos das subscrições permite concluir que a presença de assinaturas indecifráveis e iniciais revela o desejo e/ou necessidade de manutenção do anonimato por parte dos autores dos escritos. Os exemplos apontados nos escritos 42 e 44, cujos autores assinam-se como "O incógnito" e "Sua criada", reforçam esta conclusão, à medida que manifestam explicitamente esse desejo ou necessidade de ocultar a identidade. Pela análise comparativa, podemos inferir que a presença do nome dos autores nos escritos está relacionada diretamente com a datação cronológica dos mesmos. Quanto mais recente for o escrito, maior será a presença do nome do autor. As assinaturas e rubricas em que a identificação do autor é praticamente impossível, estão concentradas nos séculos XVIII e XIX; a presença de iniciais que sugerem uma identificação do autor, concentra-se na segunda metade do século XIX e na primeira metade do século $X X$, em que o anonimato vai sendo extinto gradualmente das rodas, e o uso do nome do autor na subscrição é mais tardio, sendo prevalente no século $X X$, quando a identificação dos pais tornou-se obrigatória por lei.

Em seguida, examinaremos os escritos da roda quanto à datatio tópica e cronológica. A primeira é referente à forma como está designado no documento o local 
onde ele foi assinado. A segunda corresponde ao dia, mês e ano. Observa-se que, dos 60 escritos da roda, 20 apresentam datação tópica e 32 datação cronológica.

Os dados do quadro, a seguir, apresentam as datações cronológicas e tópicas presentes nos escritos do corpus.

Quadro 14 - Datação tópica e cronológica dos escritos do corpus

\begin{tabular}{|c|c|c|}
\hline Escrito & Datação cronológica & Datação tópica \\
\hline 6 & $28=$ deFevereiro $=$ anno $=1800=$ & \\
\hline 7 & 1800 & \\
\hline 9 & hoje 9 de abril de 1839 & \\
\hline 16 & 29 de Nubenbro de 1886. & Lisboa \\
\hline 18 & 13 Janeiro 1890 & \\
\hline 19 & 22 de Fevereiro de 1892 & Lisboa \\
\hline 23 & $5-3-961$ & Salvador \\
\hline 25 & 1 de Agosto de $1961^{\prime}$ & Salvador \\
\hline 26 & $19 / 12 / 69$ & \\
\hline 29 & 24 de laneiro de 1858 & Rio de Ianeiro \\
\hline 30 & 10 de Abril de 1858 & Rio de Janeiro \\
\hline 31 & 26 de abril de1858. & Rio de Janeiro \\
\hline 32 & hoje <espaco> de Maio de 1858 & \\
\hline 33 & Hoje 1 de julho de 1858 & Rio de Janeiro \\
\hline 35 & 18 de Agosto de $\underline{\underline{1858}}$ & Rio de Janeiro \\
\hline 36 & 20 de Agosto de 1858 & Rio de Janeiro \\
\hline 37 & 4 de Setembro de 1858 & Rio de Janeiro \\
\hline 38 & 4 de Septembro de $\underline{1858}$ & Rio de Janeiro \\
\hline 39 & 2 de Novembro de 1858 & \\
\hline 41 & 17 de Dezembro 1858 & Rio de Janeiro \\
\hline 42 & 31 de Dezembro de 1858 & Rio de Janeiro \\
\hline 44 & 14 de Janeiro de 1880 & \\
\hline 48 & 22 de Junho 1901 & \\
\hline 50 & 5 de Dezembro de 1903 & Rio de Janeiro \\
\hline 51 & 27 de Junho de 955 & \\
\hline 52 & $19-7-17$ & São Paulo \\
\hline 53 & $15<7>$ de Outubro de 1920 & São Paulo \\
\hline 54 & $14-12-921$ & \\
\hline 55 & $21-2-1922$ & São Paulo \\
\hline 56 & 30 de Maio de 1922. & São Paulo \\
\hline 57 & $27-6-922$ & \\
\hline 60 & $4-10-923$ & São Paulo \\
\hline
\end{tabular}


Verificamos que 20 escritos apresentam datação completa, tópica e cronológica. Entre os escritos que apresentam datação cronológica, a grande maioria registra dia, mês e ano, com exceção do escrito 7, que registra apenas o ano. A datação cronológica é elaborada de duas maneiras pelos autores, por representação numérica ou por extenso. Cabe destacar que em 3 escritos foi consignada a presença do advérbio de tempo hoje ${ }^{96}$.

Finalizamos as análises dos protocolos inicial e final dos escritos da roda e passaremos à análise do corpo do texto dos escritos.

\subsubsection{O texto dos escritos da roda: Exposição (narratio)}

O texto de um documento constitui-se das seguintes partes, conforme ensinamento de Bellotto (2002, p. 40): preâmbulo (prologus ou exordium); notificação (notificatio ou promulgatio), exposição (narrativo), dispositivo (dispositio) sanção (sanctio ou minatio) e corroboração ou cláusulas finais (valorativo ou colaboratio). Duranti (1991, p.13) lembra que esses elementos não aparecem todos ao mesmo tempo na mesma forma documental, e muitos são mutuamente excludentes ${ }^{97}$. Os escritos que compõem nosso corpus não apresentam preâmbulos, notificações, sanções ou cláusulas finais, pelas razões já expostas anteriormente, isto é, por serem resultado de uma prática social não regulamentada, não apresentam fórmulas consagradas ou prescritas por chancelarias. Podemos afirmar que as partes constitutivas dos escritos da roda, de forma geral, estão distribuídas entre a exposição (narratio) e o dispositivo (dispositio).

Iniciamos nosso estudo do texto dos escritos da roda por meio da análise da expositio (narração).

Conforme o ensinamento de Duranti, sabemos que a substância do texto é, usualmente, introduzida por uma exposição, que é a narração das circunstâncias

\footnotetext{
${ }^{96}$ Com o emprego do dêitico "hoje", o autor refere-se à situação de produção do escrito.

${ }^{97}$ Duranti (1991, p. 15)
} 
concretas e imediatas que deram origem ao ato e/ou ao documento (DURANTI, 1991, p.13) ${ }^{98}$. A exposição depende da natureza do ato/documento. No caso dos escritos da roda, trata-se de documentos relacionados à transferência dos direitos e responsabilidades dos progenitores ou responsáveis pela criança para a roda dos expostos. Os fatos relatados e as circunstâncias apresentadas na exposição portanto, estão ligados ao nascimento de uma criança que será depositada na roda.

O relato dos autores do texto inicia-se, frequentemente, com as circunstâncias relacionadas ao nascimento, que são a data em que a criança nasceu e, mais raramente, o local de nascimento. Por meio da análise dos escritos, verificou-se que os dados mais relevantes que constam nesta parte do texto são a data de nascimento; o gênero; o nome e a menção ao batismo.

\subsubsection{Data de nascimento}

Uma das primeiras informações mencionadas pelos autores dos escritos referese à datação cronológica do nascimento da criança.

Os dados do quadro a seguir apresentam na primeira coluna, o número do escrito; na segunda coluna, a transcrição da referência à data de nascimento do exposto e, na última, a referência à hora de nascimento.

\footnotetext{
98 "Exposition is" (..) "the narration of the concrete and immediate circumstances generating the act and/or the document. (...) Thus, in documents conceding something, there is a mention of the request, of the reasons for the request and for its acceptance, and of the consensus and advice of the interested parties; in documents relating to contentious acts, there is the history of the case and its development (...). Duranti (1991, p. 13)
} 
Quadro 15 - Referência à data de nascimento do exposto nos escritos do corpus

\begin{tabular}{|c|c|c|}
\hline Escrito & Referência à data de nascimento & Horário \\
\hline Escrito 1 & vinte e dois de Setembro de mil sette centos e|noventa & onze horas emeya \\
\hline Escrito 4 & 28 de|Dezembro de1798 & \\
\hline Escrito 5 & 2 de laneiro it1800 & noite \\
\hline Escrito 7 & 30 de Marco|de Mil e oito sentos & \\
\hline Escrito 8 & 14 de novembro de 1838 & \\
\hline Escrito 9 & 9 de abril de 1839 & \\
\hline Escrito 10 & 11 de Maio de 1841 & 10 horas da manhâa \\
\hline Escrito 11 & 27 de gulho|as (...) no anno 1842 & 6 horas da trade \\
\hline Escrito 12 & 30 de outubro de $\underline{1843}$ & \\
\hline Escrito 13 & 8 de Novembro de 1843 & \\
\hline Escrito 14 & Treze de Abril de|mil eoito centos e quarenta eceis & \\
\hline Escrito 16 & 22 do mez|de Nubenbro & nove e|meia horas da noute \\
\hline Escrito 17 & 26 de Novembro & 3 -|horas da tarde \\
\hline Escrito 18 & 3 de Janéiro 1890 & 8 horas \\
\hline Escrito 19 & 26 de laneiro|de 1892 & \\
\hline Escrito 21 & 20 Outubro 1959 - 1959 & \\
\hline Escrito 22 & 19 de Agosto de 1960 & 5 hora[s]|da manha \\
\hline Escrito 23 & 9 de Dezembro de 1960 & 8 horas|da noite \\
\hline Escrito 24 & 18 de Julio de 1961 & \\
\hline Escrito 25 & 17 de novembro de 1960 & \\
\hline Escrito 27 & 30 de Abril . de1858 & \\
\hline Escrito 28 & 29 de Janeiro de1858 & 2 horas|[da] noute \\
\hline Escrito 30 & 20 de Fevereiro & \\
\hline Escrito 31 & 3 de Abril de 1858 & \\
\hline Escrito 34 & 8 de Agosto|de 1858 & \\
\hline Escrito 35 & 18 de Agosto & 9 horas da manha \\
\hline Escrito 38 & 4 de Septembro de $\underline{1858}$ & $5^{1} / \underline{4}$ da tarde \\
\hline Escrito 39 & 17 deAgosto & \\
\hline Escrito 40 & 2 de Novem|bro 1858 & \\
\hline Escrito 42 & 16 de Dezembro de 1858 & pelas cinco horas da tar $=\mid \mathrm{de}$ \\
\hline Escrito 43 & Janeiro de1880 & \\
\hline Escrito 44 & dia 13 & 11 horas da noite \\
\hline Escrito 45 & $28 \mathrm{P}$ de Fevereiro de 1880 & \\
\hline Escrito 48 & 22 de Junho 1901 & 8 da manhã| \\
\hline Escrito 49 & 5 de Dezembro de1903 & \\
\hline Escrito 51 & 12 de Junho de 955 & \\
\hline Escrito 53 & 21 de Setembro de 1920 & \\
\hline Escrito 54 & 5 de Dezembro|de 1921 & \\
\hline Escrito 56 & 8 de Janeiro de 1922 & \\
\hline
\end{tabular}


Podemos observar que dos 60 escritos, 39 apresentam referência à data de nascimento. Do total, 34 referem-se à data de forma completa, isto é, informam dia, mês e ano do nascimento da criança. A datação cronológica é elaborada de modos variados pelos autores, por representação numérica ou por extenso, tanto no dia como no ano.

Cabe destacar que alguns escritos registram como data de nascimento do exposto a data cronológica do escrito. O fato pode ser apontado pelo emprego do advérbio "hoje", que indica a coincidência de datas entre o nascimento da criança e a produção do escrito. Os escritos 9, 28, 38, 40, 48 referem-se ao "dia de hoje". O escrito 10 emprega o advérbio "ontem" para indicar a data de nascimento da criança, indicando a diferença de um dia entre o nascimento do bebê e a produção do escrito. O escrito 2, embora não informe a data de nascimento da criança, afirma que "o menino tem 1 ano e 9 dias". Como o mesmo escrito traz data cronológica, é possível inferir a data de nascimento da criança.

Alguns escritos acrescentam elementos adicionais, como a indicação do dia da semana em que a criança nasceu, como o escrito 4 ("sexta-feira"), o escrito 42 ("quinta-feira") ou o escrito 31 ("neste sábado de Aleluia"), de modo a pormenorizar ainda mais a data cronológica de entrega da criança.

\subsubsection{Gênero}

A partir do nome próprio e de outros dados presentes nos escritos de nosso corpus, é possível conhecer o gênero dos expostos depositados na roda.

Os escritos que indicam expostos de gênero masculino identificados pelo nome são os escritos $1,2,3,9,10,12,13,14,16,17,21,23,27,31,32$, 33, 34, 36, 37, 38, 40, 44, 46, 47, 49, 50, 52, 53 e 57.

Além destes, temos três escritos em que se pode identificar o gênero do exposto por outros marcadores linguísticos. São eles o escrito 19 - (“filho de Patríçio"); o escrito 55 - ("Filho não posso") e o escrito 58 - (“Ainda não está batizado") Temos, portanto, um total de 32 escritos referentes a expostos do gênero masculino.

Os escritos que indicam expostos do gênero feminino identificados pelo nome são os escritos $4,5,6,7,8,11,18,20,22,24,25,28,29,30,35,39,41,42,43,45$, $51,54,56$ e 59. Além destes, temos dois escritos em que se pode identificar o gênero do exposto indiretamente, pela forma como é designado. São eles o escrito 26 ("A 
Senhora pode entregar a menina") e o escrito 60 - ("terem Compaixão, d'esta inocente"). Temos, portanto, um total de 26 escritos referentes a expostos do gênero feminino.

Apenas dois escritos não apresentam dados suficientes para que se possa conhecer o gênero do exposto depositado na roda: o escrito 15 e o escrito 48 .

O gráfico abaixo mostra a distribuição dos expostos por gênero nos escritos de nosso corpus:

Gráfico 10 - Gênero dos expostos do corpus

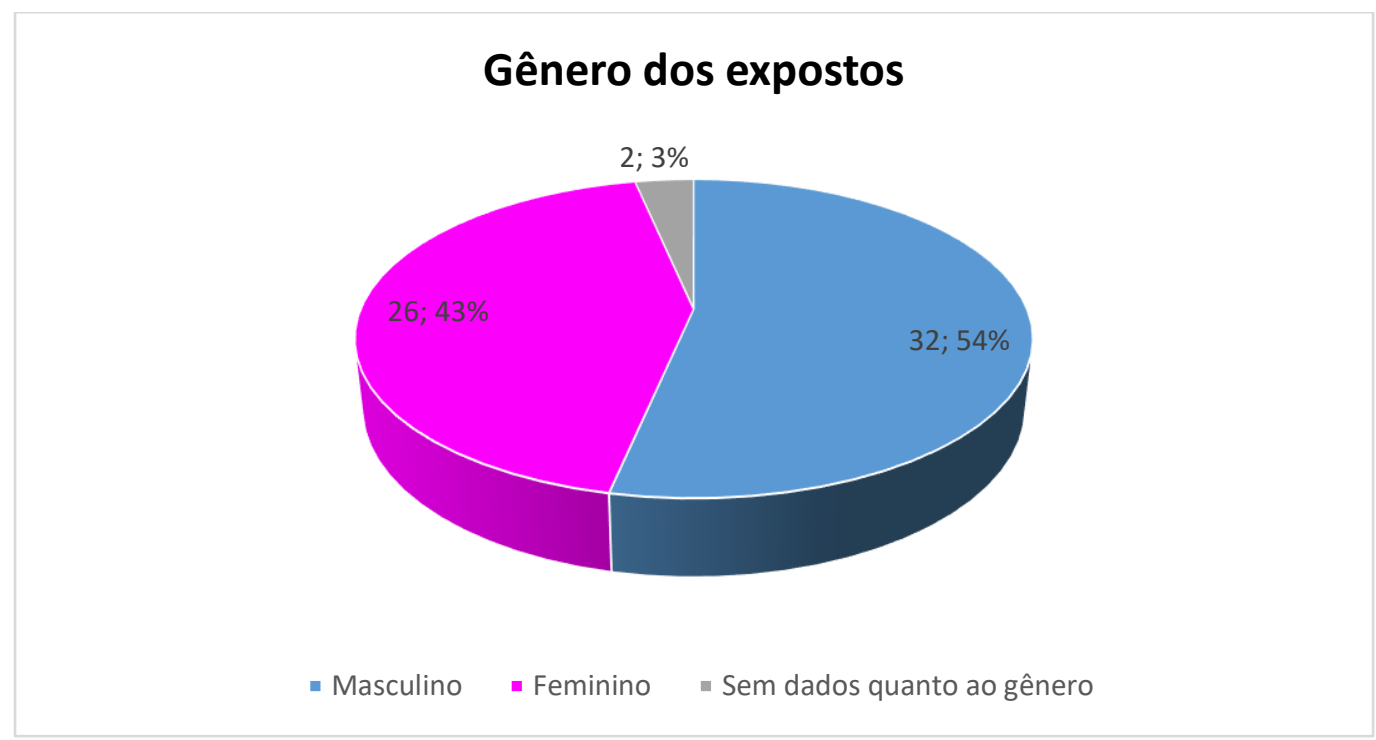

Verifica-se, portanto, uma preponderância de expostos do gênero masculino (54\%) sobre expostos do gênero feminino (43\%) em nosso corpus.

\subsubsection{Nome}

O próximo elemento analisado na exposicão do texto dos escritos é o nome do exposto.

A quase totalidade dos escritos do corpus (53 escritos) refere-se explicitamente ao nome da criança. Apenas 7 escritos $(15,19,26,48,55,58,60)$ não trazem o nome escolhido para o exposto. O padrão observado é aquele que informa apenas o prenome da criança, mas há também escritos que trazem o nome completo do expostos. A seguir, apresentamos um quadro com o levantamento exaustivo dos nomes das crianças do corpus. 
Quadro 16 - Lista exaustiva de nomes das crianças do corpus

\begin{tabular}{|c|c|}
\hline NN DO ESCRITO & NOME \\
\hline Escrito 1 & Mauricio \\
\hline Escrito 2 & Joze theadoro \\
\hline Escrito 3 & João Cancio \\
\hline Escrito 4 & Ioaquina \\
\hline Escrito 5 & Maria \\
\hline Escrito 6 & Tomazia \\
\hline Escrito 7 & Maria \\
\hline Escrito 8 & Paulina \\
\hline Escrito 9 & Julio Pedro augusto \\
\hline Escrito 10 & Jozé \\
\hline Escrito 11 & Maria de lezus \\
\hline Escrito 12 & Manoeldos Santos \\
\hline Escrito 13 & Joze Maria \\
\hline Escrito 14 & Ioaquim \\
\hline Escrito 16 & Antonio \\
\hline Escrito 17 & Carlos \\
\hline Escrito 18 & Carlota Bertha Maria José \\
\hline Escrito 20 & maria Tereza Fernandes \\
\hline Escrito 21 & José Bomfim Barbosa \\
\hline Escrito 22 & Maria das Graças \\
\hline Escrito 23 & Wilson Ribeiro dos Santos \\
\hline Escrito 24 & Isabel Cristina Marques \\
\hline Escrito 25 & Dacj Silva \\
\hline Escrito 27 & Ioaquim \\
\hline Escrito 28 & Marianna \\
\hline Escrito 29 & Severina \\
\hline Escrito 30 & Eleuteria \\
\hline Escrito 31 & Elias \\
\hline Escrito 32 & Antonio \\
\hline Escrito 33 & Idoardo \\
\hline Escrito 34 & Ioaquim Candido \\
\hline Escrito 35 & Tereza \\
\hline Escrito 36 & Felecisssimo \\
\hline Escrito 37 & Antonio \\
\hline Escrito 38 & Martinho da Rosa \\
\hline Escrito 39 & Isabel \\
\hline Escrito 40 & Victorino \\
\hline Escrito 41 & Luduvina Pereira dos prazeres \\
\hline Escrito 42 & Joséfa \\
\hline Escrito 43 & Adelina \\
\hline Escrito 44 & Hilario \\
\hline Escrito 45 & Maria \\
\hline Escrito 46 & Déodato \\
\hline Escrito 47 & Alfredo \\
\hline Escrito 49 & João \\
\hline Escrito 50 & José \\
\hline Escrito 51 & Jacinta dos Santos \\
\hline Escrito 52 & Vicente \\
\hline Escrito 53 & Carlos Penna \\
\hline Escrito 54 & Isabela \\
\hline Escrito 56 & Olevia de S. Lima \\
\hline Escrito 57 & Antionio Moreira de Carvalho \\
\hline Escrito 59 & Maria Helena \\
\hline
\end{tabular}


Do total de escritos, 36 apresentam os prenomes das crianças e 17, os nomes completos dos expostos ${ }^{99}$.

A maior parte dos escritos apresenta nomes conhecidos, que ainda hoje são utilizados em Portugal e no Brasil. Há nomes recorrentes, como Maria (7 ocorrências), José/Joze/Jozé/Josefa (6 ocorrências), Antonio (4 ocorrências), Joaquim/Joaquina (3 ocorrências) Isabel/Isabela (3 ocorrências), Carlos (2 ocorrências) e João ( 2 ocorrências). Verificamos que dos 53 escritos que indicam os nomes dos expostos, 37 escolheram um dos sete nomes acima. Os outros nomes possuem apenas uma ocorrência. Entre os prenomes, 4 deles são nomes duplos: "Maria de lezus" (escrito 11); "Joze Maria" (escrito 13); "Maria das Graças" (escrito 22) e "Maria Helena" (escrito 59). Vide distribuição da atribuição de nomes para os expostos, gráfico abaixo.

Gráfico 11 - Marcas de identificação do exposto no corpus: nome

Marcas de identificação do exposto: NOME

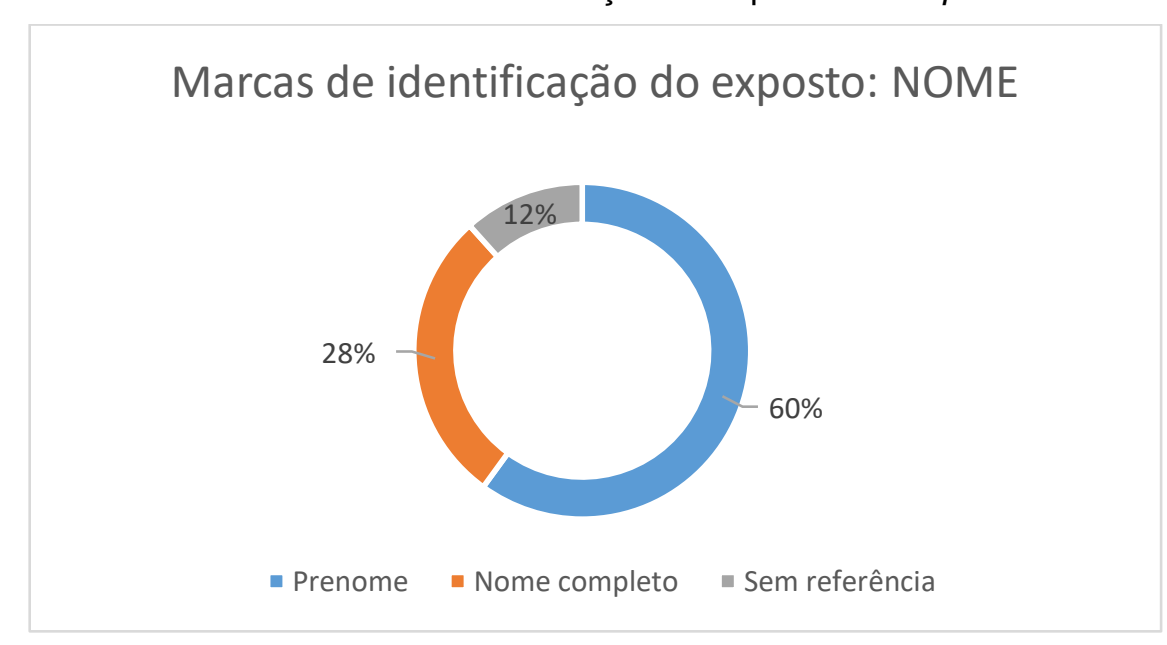

Como observamos, $88 \%$ dos escritos identificam o nome do exposto e apenas 12\% não apresentam indicação de nome.

${ }^{99}$ Alguns nomes podem ser tomados como nomes compostos ou nome e sobrenome. 


\subsubsection{O batismo}

Além do nome do exposto, a informação mais recorrente nos escritos da roda de nosso corpus refere-se ao batismo da criança. Na maior parte dos escritos, o escrito informa se o exposto já foi batizado ou solicita-se que ele seja batizado.

Os dados do quadro seguinte indicam, na primeira coluna o número do escrito, na coluna seguinte reproduzem o trecho do escrito que faz menção ao batismo, e, na última indicam se o exposto foi ou não batizado.

Quadro 17 - Lista exaustiva de nomes das crianças do corpus

\begin{tabular}{|l|l|c|}
\hline \multicolumn{1}{|c|}{ No DO ESCRITO $^{\text {TRECHO }}$} & BATIZADO \\
\hline Escrito 1 & vai por Baptizar & NÃO \\
\hline Escrito 2 & esta por bautizar & NÃO \\
\hline Escrito 3 & Ainda naõ está baptizado & NÃO \\
\hline Escrito 4 & vaj já Batizada & SIM \\
\hline Escrito 5 & para nella sebaptizar, & NÃO \\
\hline Escrito 7 & naõ Vai Baltizada & NÃO \\
\hline Escrito 10 & seja Bap|tizado & NÃO \\
\hline Escrito 11 & quando a baltizar| & NÃO \\
\hline Escrito 13 & vai por baptizar & NÃO \\
\hline Escrito 15 & não esta bap-|tizada & NÃO \\
\hline Escrito 17 & batisa|do a 28 de Novembro & SIM \\
\hline Escrito 18 & seja baptisada & NÃO \\
\hline Escrito 20 & está|Batizada & SIM \\
\hline Escrito 22 & Já estar Batizada & SIM \\
\hline Escrito 23 & Já foi batizado & SIM \\
\hline Escrito 24 & Batisada & SIM \\
\hline Escrito 25 & não é batizado, & NÃO \\
\hline Escrito 28 & Não está baptisada & NÃO \\
\hline Escrito 29 & est[ou] baptisada & SIM \\
\hline Escrito 30 & ainda não está baptisada & NÃO \\
\hline Escrito 31 & está baptisado & SIM \\
\hline Escrito 34 & ainda não está baptizado & NÃO \\
\hline Escrito 35 & para ser Baptizada & NÃO \\
\hline Escrito 38 & Seja|Baptisado & NÃO \\
\hline Escrito 41 & vai sem ser baptizada & NÃO \\
\hline Escrito 42 & de a mandar Baptizar & NÃO \\
\hline Escrito 43 & Não está|Baptizada & NÃO \\
\hline Escrito 44 & quando batizar & NÃO \\
\hline Escrito 46 & Na Pia seja-lhe este nome dado & NÃO \\
\hline Escrito 47 & não está Baptisado & NÃO \\
\hline Escrito 49 & não está baptisada & NÃO \\
\hline Escrito 51 & não esta batizada & NÃO \\
\hline Escrito 52 & Já foi baptisado & SIM \\
\hline Escrito 53 & Já foi baptisado & NÃO \\
\hline Escrito 54 & E ainda não foi bapti|sada & NÃO \\
\hline Escrito 58 & Ainda não está|[ba]tisado & NÃO \\
\hline Escrito 59 & não|está baptisada & \\
\hline & & \\
\hline
\end{tabular}


Dos 60 escritos do corpus, 37 fazem menção explicita ao batismo, sendo que 27 informam que o exposto não está batizado e 10 informam que ele já está batizado. A informação sobre o batismo está relacionada diretamente à informação sobre o nome da criança, como veremos adiante. Estas duas informações, em conjunto, serão utilizadas pelo autor do escrito na dispositio, que analisaremos adiante.

O gráfico abaixo indica a referência ao batismo nos escritos do corpus.

Gráfico 12 - Referência ao batismo do corpus

\section{Referências ao batismo no corpus}

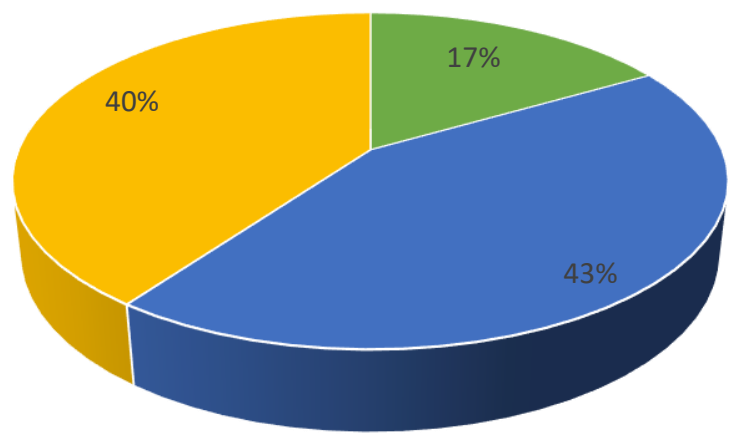

- Batizado - Não batizado $\quad$ Sem referência direta ao batismo

Verificamos que $60 \%$ dos escritos do corpus fazem referência direta ao batismo da criança, e na maioria destes escritos (quase metade dos escritos do corpus), o autor manifesta o desejo de que a criança seja batizada pela instituição da roda. É digna de nota também que uma pequena parcela de expostos (17\%) tenha entrado na roda já batizada. 


\section{Expostos batizados}

O gráfico abaixo indica a distribuição dos expostos batizados por períodos de meio século.

Gráfico 13 - Expostos batizados do corpus

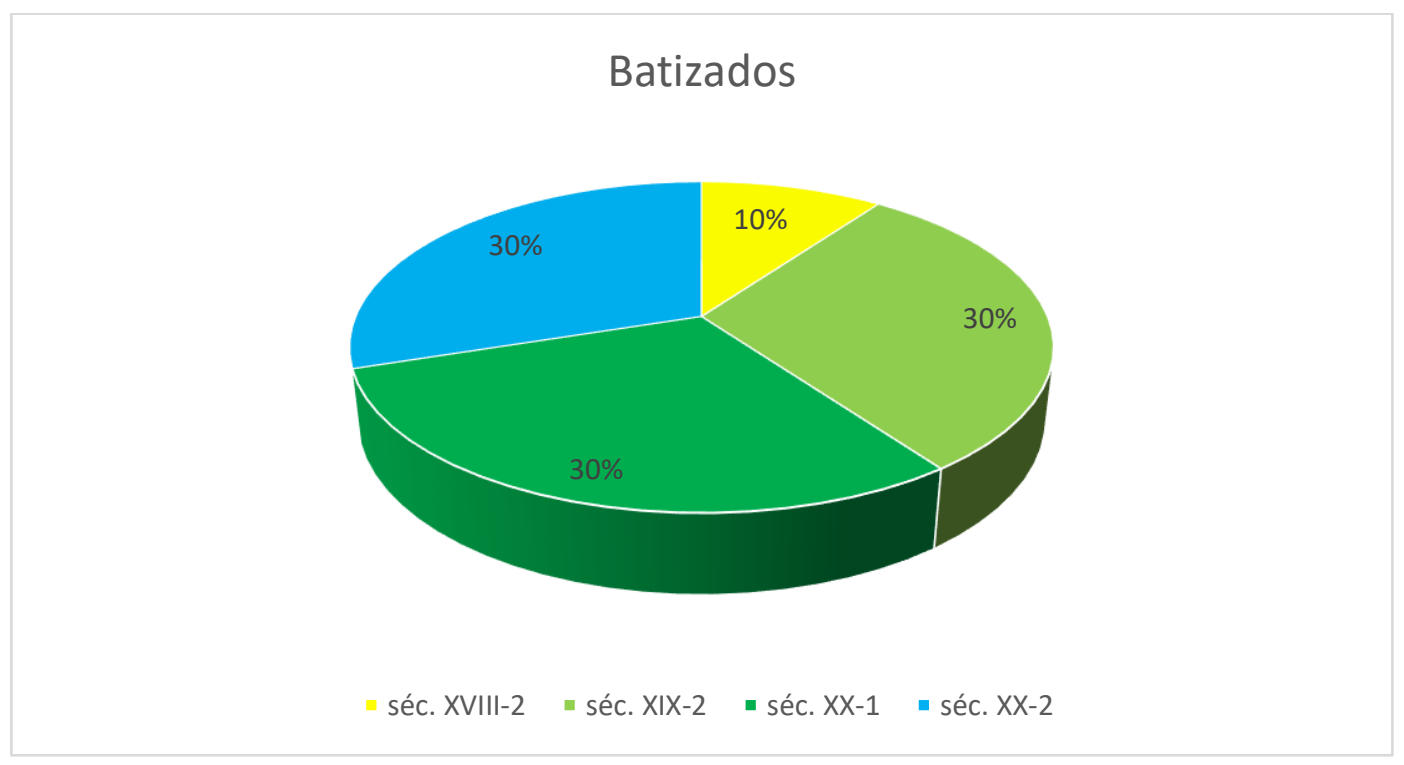

Verificamos que uma pequena fração dos expostos já batizados estão na segunda metade do século XVIII (10\%), enquanto os demais distribuem-se igualmente pela segunda metade do século XIX e pelas primeira e segunda metades do século $X X$. 


\section{Expostos não batizados}

O gráfico abaixo indica a distribuição dos expostos não batizados por períodos de meio século.

\section{Gráfico 14 - Expostos não batizados do corpus}

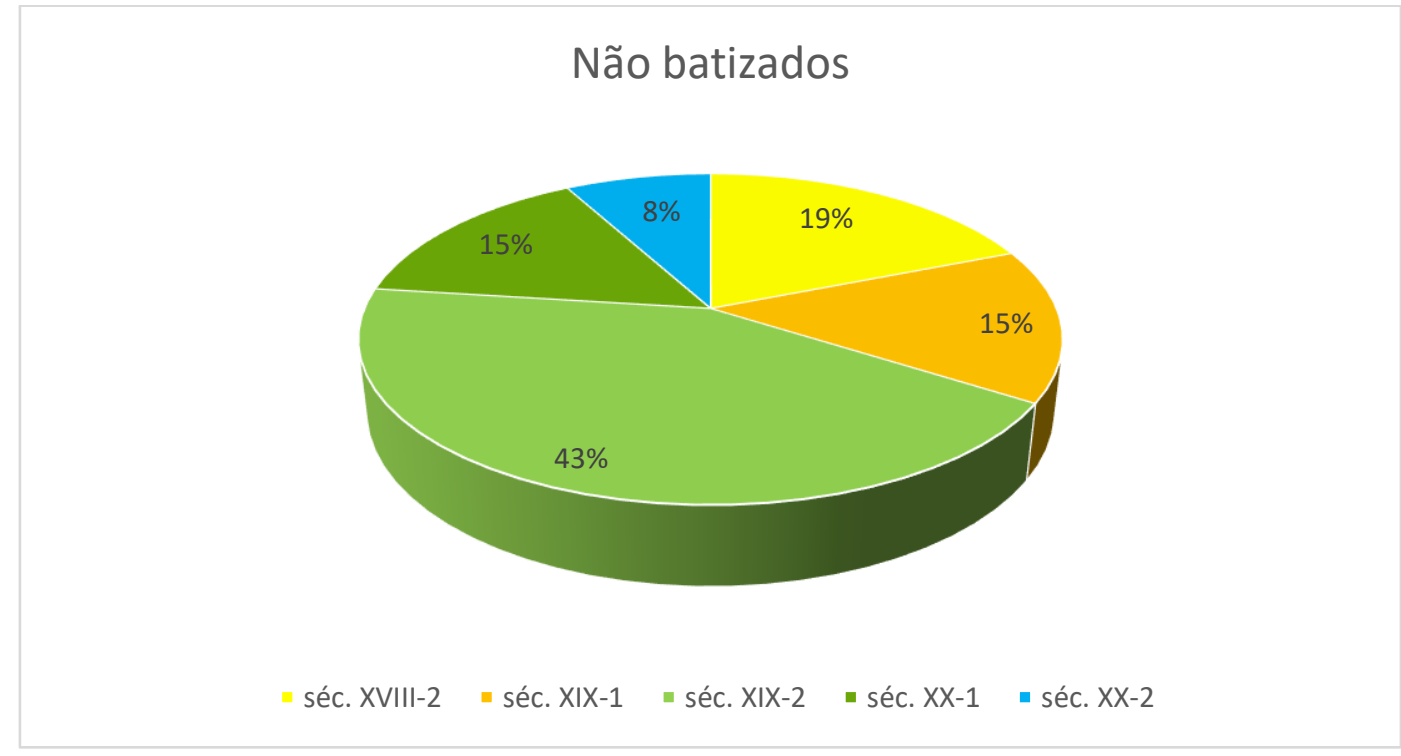

Observamos a menção dos escritos aos expostos não batizados em todos os períodos analisados. A maior proporção (43\%) concentra-se na segunda metade do século XIX, distribuindo-se nos outros períodos de forma mais ou menos equilibrada.

Além da referência ao nome e a informação sobre o batismo, outras informações podem ser encontradas na exposição dos textos da roda. Podemos mencionar escritos que trazem o nome de um dos progenitores da criança, ou de ambos, escritos que referem o enxoval da criança, escritos que informam as condições de saúde da criança ou dos pais e escritos que trazem justificativas para o depósito na roda. Estes dados ${ }^{100}$, no entanto, aparecem ocasionalmente nos escritos, não se constituindo em um padrão que possa ser observado no conjunto dos escritos, pelo que não serão analisados exaustivamente em nosso trabalho ${ }^{101}$.

Cabe ressaltar que, como explica Duranti (1991, p. 13) "muitos documentos, tanto públicos quanto privados, originam-se de situações análogas. Nesses casos, a narrativa torna-se uma fórmula estereotipada". Certamente, os escritos da roda

100 Esses dados aparecem ocasionalmente também no total de escritos consultados (aproximadamente 800) e que não pertencem ao corpus dessa pesquisa. 
originam-se de situações análogas e as formulações que encontramos em suas narrativas são muito semelhantes umas às outras. A narrativa que a expositio dos textos da roda contém, basicamente, afirma que: "em tal data e/ou local, nasceu uma criança; seu nome é tal; ela está/não está batizada."

\subsubsection{Formulação da expositio dos textos}

Após o levantamento e estudo dos dados mais relevantes que constam nesta parte do texto dos escritos da roda, verificamos como tais dados - a data de nascimento; o gênero; o nome e a menção ao batismo - correlacionam-se para formulação da exposição do texto.

Apresentamos os resultados de um estudo a respeito das fórmulas usadas pelos autores dos escritos, para criar suas narrativas na expositio dos documentos. De maneira geral, os autores utilizam construções simples, em ordem direta, com o uso das flexões dos verbos nascer, entrar e ir. Nesses casos, o sujeito, em geral, é a própria criança.

Quadro 18 - Formulação da expositio dos escritos da roda com os verbos nascer, entrar e ir

\begin{tabular}{|c|c|}
\hline $\begin{array}{l}\text { Número } \\
\text { do escrito }\end{array}$ & $\begin{array}{l}\text { Formulação utilizada para criar narrativa na expositio dos documentos - verbos } \\
\text { nascer, entrar e ir }\end{array}$ \\
\hline Escrito 1 & Naseu este Menino pellas onze horas \\
\hline Escrito 2 & Ahi Vay hese Menino Com hidade dehum \\
\hline Escrito 4 & vaj já Batizada \\
\hline Escrito 7 & Emtre para a Santa Caza da Mizericordia estal Minina \\
\hline Escrito 8 & Nasceu esta Menina \\
\hline Escrito 9 & hoje entra para a Santa Caza da Mizericordia \\
\hline Escrito 10 & Nasceu honte 11 de Maio de 1841 \\
\hline Escrito 11 & Esta menina Nasseo no dia 27 de gulho \\
\hline Escrito 12 & nasçeu no dia 30 de outubro \\
\hline Escrito 13 & Nasceo este menino em 8 de Novembro \\
\hline Escrito 14 & nasceu no dia Treze de Abril \\
\hline Escrito 16 & Este Menino nasceu no dia 22 do mez de Nubenbro \\
\hline Escrito 17 & Nasceu a 26 de Novembro \\
\hline Escrito 18 & Ella nasceu no dia 3 de Janéiro \\
\hline Escrito 19 & Nascêo a 26 de laneiro \\
\hline Escrito 22 & Maria das Graças naceu mol dia 19 de Agosto de 1960 \\
\hline Escrito 23 & Nasceu no dia 9 de Dezembro \\
\hline Escrito 28 & A criança que este bilhete accompanha|[nas]cêo hoje 29 de Janeiro de1858, as 2 horas \\
\hline Escrito 30 & Esta innocente nasceu a 20 de Fevereiro \\
\hline Escrito 33 & entra esta crianca para a roda \\
\hline Escrito 34 & Este innocente nasceu a 8 de Agosto|de 1858 \\
\hline Escrito 37 & Este menino que vai para a roda \\
\hline Escrito 41 & A Portadora vai sem ser baptizada \\
\hline Escrito 43 & Esta menina naçeo no dia| de Janeiro de 1880 \\
\hline Escrito 45 & nasceu no| dia 28 \\
\hline
\end{tabular}


Outro modo de narrar as circunstâncias do nascimento do exposto e de seu depósito na roda consiste no emprego dos verbos entregar, remeter, botar, deixar e pôr. Nestes casos, em geral, o sujeito é o próprio autor do escrito.

Quadro 19 -Formulação da expositio dos escritos da roda com os verbos entregar, botar, remeter, deixar e por

\begin{tabular}{|l|l|}
\hline $\begin{array}{l}\text { Número do } \\
\text { escrito }\end{array}$ & $\begin{array}{l}\text { Formulação utilizada pra criar narrativa na expositio dos documentos } \\
\text { verbos entregar, remeter, botar, deixar e pôr }\end{array}$ \\
\hline Escrito 6 & Entrego naSanta Caza da Miziricordia hua imposta \\
\hline Escrito 22 & botei por necedade \\
\hline Escrito 27 & Remeto esta crianca que nacio a 30 de Abril \\
\hline Escrito 35 & emtrego aminha filha \\
\hline Escrito 36 & Remeto este menino para ser| criado com alguma delica|deza \\
\hline Escrito 48 & Eu vos entrego essa criança \\
\hline Escrito 51 & Deicho esta criança para ser dada \\
\hline Escrito 52 & Ponho meu filho na| roda por motivo de miséria \\
\hline
\end{tabular}

Nota-se grande diversidade entre os escritos da roda na maneira como o autor do texto se refere ao exposto. Na maior parte dos escritos, é utilizada a forma "criança" (14 ocorrências) , "menino" ou "menina" (18 ocorrências).

Encontramos também o uso do termo "inocente" (escritos 30, 34, 42, 44 e 60), "anjinho" (escrito 32 "Aqui fica depositado este anyinho"), e "garotinho" (escrito 25 "Esta garotinho tem 9 mezês"). Há exemplos também do uso dos termos "inposta" (escrito 6 "Entrego naSanta Caza da Miziricordia hua imposta") e "infeliz" (escrito 10 "Este infeliz innocente").

Uma outra forma de se referir ao exposto é a utilização do termo "filho" ou "filha", o que ocorre em 5 escritos. Em alguns, observamos que o autor refere-se ao exposto como "este" (escrito 56 "Faço Saber que Este Naceu"), "o recém presente" (escrito 38 "Pedese ofavor que o resçan presente Seja Baptisado") ou "a portadora" (escrito 41 "A Portadora vai sem ser baptizada"). No escrito 22, o nome próprio é utilizado para fazer referência ao exposto ("Maria das Graças naceu mol dia 19 de Agosto)

Verificou-se também a existência de escritos narrados em $1^{\text {a }}$ pessoa, nos quais o exposto aparece como autor do texto. É o caso dos escritos 29 (Eu chamo-me Severina, est[ou] baptisada ) e 57 (Chamo-me Antonio.| Sou um orphãosinho ).

Notamos uma regularidade nos escritos da roda em relação às informações básicas fornecidas pelo autor sobre a criança depositada na roda. Esta constatação revela que, mesmo não se tratando de documentos oficiais, os escritos da roda apresentam-se como documentos informais de identificação da criança e que, embora 
não haja chancela, nem fórmulas divulgadas aos escritos das rodas por meio de um manual, até onde se tem notícia, as informações que, habitualmente, constam nos escritos apresentam certa padronização. Em sua grande maioria, os autores dos escritos evidenciam a intenção de deixar um registro dos dados essenciais sobre a criança.

\subsubsection{Texto: Dispositivo (Dispositio)}

O dispositivo (dispositio) é a peça chave de um ato qualquer, pois é nela que se expressa a vontade do autor: "Sem dispositio não haveria ato e de sua inteligibilidade, de sua clareza, da precisão dos termos empregados depende em grande parte a eficácia do escrito", explica Tessier (1952, p. 44).

A maioria dos textos do escritos possui, explicitamente, uma parte que contém as disposições do autor seja em relação ao exposto, seja em relação à intenção de buscar a criança em um tempo futuro. Cabe lembrar que, assim como alguns escritos não apresentam esta parte do texto, outros trazem diversas solicitações em uma mesma dispositio.

$\mathrm{Na}$ análise dos escritos da roda, observa-se que o autor do escrito expressa uma vontade. Duranti (1991) explica que "no dispositivo, o fato ou ato está expressamente enunciado, usualmente por meio de um verbo capaz de comunicar a natureza da ação e a função do documento, como autorizar, promulgar, decretar, certificar, concordar e solicitar ${ }^{102}$.

Nos escritos que analisamos, a função do documento é expressa por verbos como pedir, desejar, rogar, implorar e suplicar. Para realizar esta análise, separamos os escritos, de acordo com as solicitações expressas na dispositio.

\footnotetext{
102 Disposition: the core of the text is the disposition, that is, the expression of the will or judgement of the author. Here, the fact or act is expressly enunciated, usually by means of a verb able to communicate the nature of the action and the function of the document, such as "authorize", "promulgate,", "decree", "certify", "agree", "request", etc. The verb may be preceded by a word or locution which puts the dispositon in direct relationship to the previous exposition or preambule, such as "therefore", "hereby", etc. (DURANTI, 1991, p. 13)
} 


\subsubsection{Formulação de dispositio nos textos}

Em primeiro lugar, tratamos das solicitações do autor em relação ao exposto. Em seguida, tratamos das solicitações do autor quanto à intenção de buscar a criança e aos sinais.

Entre as solicitações do autor do texto, encontramos aquelas que tratam do batismo da criança, caso ela ainda não esteja batizada. É o que ocorre nos escritos 18 ("Peço que minha filha seja batizada") e 38 ("Pede-se o favor que o reçen presente seja batizado"). Nesta categoria, estão também as solicitações em relação ao nome destinado à criança. É o que ocorre no escrito 28 ("Pede-se que the deem o nome Mariana" e no escrito 30 ("roga-se -I põr-lhe o nome de - Eleuteria").

A solicitação pode referir-se ao tratamento a ser dado à criança. Um exemplo pode ser encontrado no escrito 32 ("rogo-ce de novo I a caridade do bom tratamento" e no escrito 10 ("Seus Progenetores, rogão que seja carinhozamente trac- I tado“).

A vontade do autor pode expressar-se também no sentido do destino que se dará à criança. Verificamos estas determinações nos escritos 25 ("Peço que não dê minha filha"), 26 ("A senhora pode entregar a menina a quem a senhora achar que tem credencial"), 40 ("Roga-se o conservar esta cri lansa") e 23 ("Peço que fiquem com esta I criança”).

A seguir analisaremos os textos que contêm uma dispositio em que o autor manifesta a intenção de buscar a criança e solicita que o destinatário conserve o(s) sinal(is).

\subsubsection{Referência aos sinais na dispositio dos textos}

Observamos que mais da metade dos autores dos escritos da roda pertencentes a nosso corpus manifesta a intenção de deixar sinais com o propósito de possibilitar o reconhecimento da criança em um tempo futuro. As referências aos sinais encontram-se nos escritos $2,3,4,5,6,9,11,12,15,17,18,19,20,27,28,30$, $32,33,34,35,36,37,39,40,41,43,45,48,49,50,52,53,55,58$ e 59.

Em grande parte desses escritos, a dispositio está explicitada pelo emprego de verbos como guardar, buscar, conservar, pedir, procurar, reclamar, rogar e tirar. Notase que, alguns escritos, embora os autores mencionem sinais, não explicitam no texto 
a vontade ou a intenção de buscar a criança. É o que ocorre nos escritos 3, 5, 6, 9, $11,12,17,18,19,28,32,36$ e 58.

\section{A seguir, os dados do quadro mostram na primeira coluna o número do escrito}

e na segunda, a referência direta que o autor faz ao sinal.

\section{Quadro 20 - Menção ao sinal nos escritos do corpus}

\begin{tabular}{|c|c|}
\hline Escrito & Menção ao sinal \\
\hline Escrito 2 & e Este esCrito o gardaraõ bem aRecadado porCauza| deque Seus pais oquerem tirar Sedo \\
\hline Escrito 3 & o signal| he este mesmo bilhete. \\
\hline Escrito 4 & $\begin{array}{l}\text { A Seu | tempo se procurará, este bilhete| uaj asim com estes sinais golpi|ados para comparicer| } \\
\text { com o outro que fica| do mesmo Theor }\end{array}$ \\
\hline Escrito 5 & Ileva de Sinal huma| medida denosa Senhora do cabo \\
\hline Escrito 6 & para maior signal nobraço Esquerdo hum| Laço defita branca \\
\hline Escrito 9 & $\begin{array}{l}\text { Leva por sinal| hum vestido de paninho recurtadol por baxo e Com hũ bocado cortadol que fica } \\
\text { por sinal }\end{array}$ \\
\hline Escrito 11 & $\begin{array}{l}\text { Luvan|do pro sinal huma ruzeta branca en Car|nada e Verde, (...)|para que todo| tempo que } \\
\text { esta menina se proqure pro| sinal que leua. }\end{array}$ \\
\hline Escrito 12 & ficapor sinal esteuistido| decaça cordellaranja \\
\hline Escrito 15 & pedece que se guarde| este Belhete para Sêr procu-|rado em tempo \\
\hline Escrito 17 & luvando um signal em| toda a roupa \\
\hline Escrito 18 & A créança leva vestido uma camisola de flanella| azul egual a aquelle boccado que aqui está \\
\hline Escrito 19 & $\begin{array}{l}\text { léva o retrato de seu| Pai dentro d'uma bolsinha de| fazenda aos ramos, com uma| fita } \\
\text { encarnada de seda. }\end{array}$ \\
\hline Escrito 20 & Goardeim o escrito \\
\hline Escrito 27 & cuando se for a tirar| se entregara a mitade deste papel que tem| as inisias do seu Pai \\
\hline Escrito 28 & A criança que este bilhete accompanha \\
\hline Escrito 30 & $\begin{array}{l}\text { só terá direito a ella a pessoa que apresentar o pedaço| que nesta lhe falta e que servirá de } \\
\text { talaõ e por isso se| roga o Archivo desta. }\end{array}$ \\
\hline Escrito 32 & $\begin{array}{l}\text { E que não haja ingano pois devem | hir buscar | leva esta fita para de viza |no brasçinho leva } \\
\text { desta mesma fita }\end{array}$ \\
\hline Escrito 33 & que a todo o tempo ade ser| percorada porico e que leva este sinal \\
\hline Escrito 34 & $\begin{array}{l}\text { e talvez tornar a receber| para sua companhia; e por isso ol deixa com os seguintes signaes.| } \\
\text { Uma argolinha de ouro na ore=|lha esquerda.| um sinteiro de chita côr de café.|com flores } \\
\text { brancas miúdas.|Um barrete tambem de chita ro=|xa com raminhos pretos. }\end{array}$ \\
\hline Escrito 35 & com este sinal| e mais huma manta que leva embrulhada fica| hum pedaço irej procurar \\
\hline Escrito 36 & Para ser procurado no fim | de hum anno; o nome e Fe-|lecisssimo para signal \\
\hline Escrito 37 & $\begin{array}{l}\text { vai para a roda comosssignais Seguintes| hum Lenco [[Lenco]] nacabeça Branco de linho } \\
\text { huma toucal di Cambrainha bordada| para atodo tempo| que Seposa hir buscar pelo nome } \\
\text { iSignaes que leva| Se for Vivo }\end{array}$ \\
\hline Escrito 39 & $\begin{array}{l}\text { Pede-se para que que lhe conservem sempre| ao pesçoço a medalha que leva,| dentro da qual } \\
\text { existe o signal do| seu reconhecimento, }\end{array}$ \\
\hline Escrito 40 & $\begin{array}{l}\text { pertendem recla|malla; deseja a Maÿ que se| chame Victorino: e com hum-| papel igual aeste, } \\
\text { sehade al presentar quem ofor reclamar. }\end{array}$ \\
\hline Escrito 41 & $\begin{array}{l}\text { com onome| de Luduvina Pereira dos prazeres o que| fica acrivado todos os signaes| Hum } \\
\text { Pedido de Hum sem| Parente }\end{array}$ \\
\hline Escrito 43 & foi botada a roda [l]evando de sinal uma fita| [az]ul 'marinho \\
\hline Escrito 45 & $\begin{array}{l}\text { Tenha bondade de guardar| este signal por Favor em todo| tempo esta criança hade ser| } \\
\text { procurada. }\end{array}$ \\
\hline Escrito 48 & Pesso a esmola marcala com E.C. \\
\hline Escrito 49 & $\begin{array}{l}\text { em tempo será reclamada por quem| entregar um papel egual a este e o pedaço que falta } \\
\text { n'esta medalha }\end{array}$ \\
\hline Escrito 50 & $\begin{array}{l}\text { os [rasgado] que darei são;| uma copia d'esta carta el uma medalha com o nome| de meu filho } \\
\text { e o meu - guardarei| uma medalha e a outra igual| acompanha meu filho }\end{array}$ \\
\hline Escrito 52 & Peço a caridade de guardar| este papel. \\
\hline Escrito 53 & $\begin{array}{l}\text { Pede-se a caridade de con-|servar como reliquia sagrada.| a correntinha com a medalha| da } \\
\text { Virgem da Conceição, nol pescocinho, que é cuprimento| de uma promessa. }\end{array}$ \\
\hline Escrito 55 & peço não o darem sem que levem uma carta| igual a esta e o retrato também \\
\hline Escrito 58 & por padrinho ol Sagrado Coração de Jesus \\
\hline Escrito 59 & $\begin{array}{l}\text { Peço| ele também não dar| ella a ninguem| Peço tambem nun[ca]| tirar esta medalha| do pescoço } \\
\text { della. }\end{array}$ \\
\hline
\end{tabular}


No total, são 35 escritos que fazem menção a sinais; os que não fazem qualquer referência a sinais são os de número $1,7,8,10,13,14,16,21,22,23,24$, $25,26,29,31,38,42,44,46,47,51,54,56,57$ e 60.

O tipo de sinal mais recorrente é a solicitação da guarda do escrito, como é o caso dos escritos 2, 3, 4, 15, 20, 33, 35, 40, 45, 49, 50, 52 e 55. O autor do escrito 55, por exemplo, solicita explicitamente ao destinatário "guardar o escrito como sinal". Alguns autores referem-se ao fato de possuírem uma cópia do escrito, como é o caso dos escritos 40 e 49, cujos autores afirmam possuir "um papel igual a este" ou do autor do escrito 50, que afirma possuir "uma cópia desta carta". Em outros casos, há referência à parte faltante do escrito, como nos escritos 27 e 30.

Outro tipo de sinal, presente nos escritos de nosso corpus, refere-se a sinais que a criança levava junto ao corpo. Os escritos 6 e 32 fazem referência a "sinais no braço" da criança, que serviriam para identificá-la.

Outro sinal mencionado nos textos são peças do enxoval da criança, como aquelas que são descritas no escrito 9 ("Pedro augusto Leva por sinal I hum vestido de paninho recurtado | por baxo e com hũ bocado cortado | que fica por sinal"). As peças do enxoval que eram depositadas junto ao exposto ou aquelas que ele trazia junto ao corpo eram, muitas vezes, descritas com detalhes ${ }^{103}$.

O escrito 34 refere uma argolinha de ouro na orelha esquerda da criança. Os escritos 39, 53 e 59 referem-se a medalhas no pescoço das crianças.

Há ainda sinais que só apresentam uma ocorrência no corpus. É o caso dos Escritos 36, 41, 48 e 58. No escrito 36, o sinal é o nome da criança ("o nome e Felecisssimo para signal"). O escrito 48 solicita que se marque a criança com iniciais ("Pesso a esmola marcala com E.C."). O escrito 58 sugere que um santinho que acompanha o escrito seja o sinal. No escrito 41, o autor refere-se aos sinais da seguinte forma: " fica acrivado todos os signaes|".

Ao estudar os escritos que fazem menção aos sinais, verificamos a convergência de certos elementos extrínsecos e intrínsecos estudados anteriormente. É digno de nota que os escritos que mencionam textualmente sinais também apresentem variação na composição do suporte, variação no formato do suporte, acréscimos ao texto e elementos anexados ao suporte.

\footnotetext{
103 Reunimos em apêndice o nosso trabalho dois indices de termos, um de termos utilizados na descrição das peças do enxoval e dos sinais e outro de termos relacionados ao contexto das Rodas dos Expostos.
} 
Tomamos como exemplo o escrito 4:

Referência textual ao sinal: "A Seu | tempo se procurará, este bilhete | uaj asim com estes sinais golpi | ados para comparecer | com o outro que fica | do mesmo Theor".

Variação na composição do suporte: Papel azul claro

Variação no formato do suporte: Corte oblíquo com saliência na parte central

Cotejando as informações, podemos inferir que o corte realizado no papel dividiu o escrito em duas partes com o mesmo teor e que uma delas ficou em poder do autor, para servir como sinal no momento de eventual retirada do exposto. Também podemos inferir, com menos certeza, que a escolha do papel tenha sido deliberada.

Vejamos o escrito 15.

Referência textual ao sinal: "pedece que se guarde| este Belhete para Sêr procu-|rado em tempo"

Variação na composição do suporte: Papel branco pautado

Variação no formato do suporte: Recorte irregular do papel na margem esquerda

Elementos anexados ao suporte: Alfinete perpassado horizontalmente no final da mancha, após a assinatura

Acréscimos ao texto: Traçado espiralado na margem esquerda do texto

O autor solicita que se guarde o bilhete. Cotejando a variação no formato do papel (recorte no papel) com os acréscimos ao texto (traçados espiralados) observamos que ambas as alterações estão superpostas, o que é um forte indício da intenção do autor na produção do escrito. (A mesma superposição de recortes e acréscimos ao texto acontece no escrito 7.) Podemos inferir, com menor grau de certeza, que a utilização de variação na composição do papel tenha sido deliberada. Com relação ao alfinete anexado ao suporte, só podem ser construídas hipóteses, de que tenha relação com a assinatura do autor (pois está perpassado no papel ao lado da assinatura) ou com alguma peça do enxoval do exposto.

A seguir, os dados do quadro indicam a convergência de elementos extrínsecos e intrínsecos nos escritos que fazem menção aos sinais. A primeira coluna traz o 
número do escrito, a segunda aponta variação na composição do suporte, a coluna seguinte mostra variação no formato do suporte, a quarta coluna refere-se a elementos anexados ao suporte e a última aponta acréscimos ao texto; o X indica a presença da característica.

Quadro 21 - Convergência de elementos extrínsecos e intrínsecos nos escritos do corpus

\begin{tabular}{|c|c|c|c|c|}
\hline Escrito & $\begin{array}{c}\text { Composição do } \\
\text { suporte }\end{array}$ & $\begin{array}{l}\text { Formato do } \\
\text { suporte }\end{array}$ & $\begin{array}{c}\text { Elementos anexados } \\
\text { ao suporte }\end{array}$ & Acréscimos ao texto \\
\hline \multicolumn{5}{|l|}{ Escrito 2} \\
\hline Escrito 3 & $X$ & $X$ & & \\
\hline Escrito 4 & $X$ & $\mathrm{X}$ & & \\
\hline Escrito 5 & & $\mathrm{X}$ & $\mathrm{X}$ & \\
\hline Escrito 6 & & & $X$ & \\
\hline \multicolumn{5}{|l|}{ Escrito 9} \\
\hline Escrito 11 & $X$ & & $\mathrm{X}$ & \\
\hline Escrito 12 & & & & $\mathrm{X}$ \\
\hline Escrito 15 & $X$ & $\mathrm{X}$ & $\mathrm{X}$ & $\mathrm{X}$ \\
\hline \multicolumn{5}{|l|}{ Escrito 17} \\
\hline Escrito 18 & & & $\mathrm{X}$ & \\
\hline Escrito 19 & $X$ & & $\mathrm{X}$ & \\
\hline Escrito 20 & $\mathrm{X}$ & & & \\
\hline Escrito 27 & $X$ & $\mathrm{X}$ & & \\
\hline \multicolumn{5}{|l|}{ Escrito 28} \\
\hline Escrito 30 & $X$ & $\mathrm{X}$ & & \\
\hline \multicolumn{5}{|l|}{ Escrito 32} \\
\hline \multicolumn{5}{|l|}{ Escrito 33} \\
\hline \multicolumn{5}{|l|}{ Escrito 34} \\
\hline \multicolumn{5}{|l|}{ Escrito 35} \\
\hline \multicolumn{5}{|l|}{ Escrito 36} \\
\hline \multicolumn{5}{|l|}{ Escrito 37} \\
\hline \multicolumn{5}{|l|}{ Escrito 39} \\
\hline \multicolumn{5}{|l|}{ Escrito 40} \\
\hline \multicolumn{5}{|l|}{ Escrito 41} \\
\hline Escrito 43 & $\mathrm{X}$ & & $\mathrm{X}$ & \\
\hline \multicolumn{5}{|l|}{ Escrito 45} \\
\hline Escrito 48 & $\mathrm{X}$ & & & \\
\hline Escrito 49 & $\mathrm{X}$ & $\mathrm{X}$ & & \\
\hline Escrito 50 & $\mathrm{X}$ & $\mathrm{X}$ & & \\
\hline \multicolumn{5}{|l|}{ Escrito 52} \\
\hline Escrito 53 & $\mathrm{X}$ & & & \\
\hline Escrito 55 & $X$ & & & \\
\hline Escrito 58 & $X$ & $\mathrm{X}$ & & \\
\hline Escrito 59 & $\mathrm{X}$ & & & \\
\hline
\end{tabular}

Observamos que vários escritos apresentam convergência de elementos diplomáticos analisados com a menção textual aos sinais. No escrito 18, o autor afirma que a criança veste "uma camisola de flanela azul" do mesmo tecido colado ao escrito (elemento anexado ao suporte). No escrito 43, o autor refere-se a uma fita azulmarinho, que também está colada ao escrito (elemento anexado ao suporte). Há 
casos em que ocorre a menção textual aos sinais, porém, esta não é complementada por elementos não textuais.

Tendo efetuado a análise diplomática dos elementos extrínsecos intrínsecos dos documentos da roda dos expostos, agruparemos os escritos com o objetivo de proceder a uma classificação tipológica dos mesmos. 



\section{PROPOSTA TIPOLÓGICA}

No capítulo anterior, estudamos os aspectos extrínsecos (composição e formato do suporte, elementos anexados ao suporte e acréscimos) e intrínsecos (protocolo inicial, protocolo final e texto) dos escritos da roda, considerando entre outras, também a lição de Cambraia de que "a decifração e a reprodução de um documento podem ser realizadas com mais segurança e propriedade quando se tem consciência de (...) como se estruturavam internamente, sobretudo, porque apresentavam constantes formais em termos, tanto estruturais como linguísticos" (CAMBRAIA, 2005, p. 25). Isto feito, neste capítulo, iremos proceder a uma análise tipológica dos escritos da roda a partir da diplomática.

Neste capítulo, procedemos a uma análise tipológica dos escritos da roda a partir da Diplomática. Nesta etapa da investigação, a comparação entre os diferentes escritos de datas e locais diversos fornecem perspectivas elucidativas a respeito do que pode ser chamado de uma cultura da roda. No decorrer deste capítulo, valemonos de exemplos de todo o corpus para análise. Exemplificamos os tipos de escrito a partir da transcrição justalinear de escritos selecionados no corpus.

\subsection{ESCRITOS DO TIPO $1\left(\mathrm{~T}_{1}\right)$}

A partir da consulta de grande número de escritos ${ }^{104}$, além daqueles que analisamos em nosso corpus, concluímos que grande parte dos escritos da roda apresentam características correspondentes à espécie documental carta (Bellotto, 2002, p. 51). A carta, do ponto de vista diplomático, é um documento de desenho mais ou menos padronizado e informativo:

"a carta é uma forma de correspondência largamente utilizada para transmitir
informações, solicitar favores, fazer convites etc. Sem ser obrigatório,
diplomaticamente, há uma certa padronização. Protocolo inicial: datas tópica
e cronológica. Endereçamento. Direção. Texto: paragrafado, com a
exposição e o objetivo da carta. Protocolo final: fecho de cortesia, assinatura,
nome e cargo do signatário (BELLOTTO, 2002, p. 51-2).

104 Consultamos um total de aproximadamente 800 escritos da Roda, entre os vários arquivos pesquisados. 
Os escritos que obedecem a esse padrão denominam-se escritos do tipo $1\left(\mathrm{~T}_{1}\right)$. Como exemplo de $T_{1}$, reproduzimos a seguir o escrito 50.

Rio de Janeiro 5 de Dezembro de 1903

\section{Excelentíssimas Irmãs}

Peço guardar meu filho até que as minhas forças

5 permittaõ ir buscal-o com o auxilio [rasgado] ${ }^{105} \mathrm{~s}$ e das Boas Irmãs, [rasgado] filho chama-se; José e os [rasgado] que darei são; uma copia d'esta carta e

10 uma medalha com o nome de meu filho e o meu - guardarei uma medalha e a outra igual acompanha meu filho Cassianna

15 que fica agradecida e pede a Deus pela felicidade de todos

A carta segue a padronização proposta por Bellotto, e pode ser dividida em três partes: protocolo inicial, texto (exposição e dispositivo) e protocolo final.

\begin{tabular}{|c|c|c|}
\hline Protocolo inicial & $\begin{array}{l}\text { Data tópica } \\
\text { Data cronológica } \\
\text { Endereçamento }\end{array}$ & $\begin{array}{l}\text { Rio de Janeiro } \\
5 \text { de Dezembro de } 1903 \\
\text { Excelentíssimas Irmãs }\end{array}$ \\
\hline Texto & $\begin{array}{l}\text { Expositio } \\
\text { Dispositio }\end{array}$ & $\begin{array}{l}\text { filho chama-se; |José e } \\
\text { Peço guardar meu filho |até que as minhas } \\
\text { forças |permittaõ ir buscal-o com |o auxilio } \\
\text { [rasgado]s e das Boas |Irmãs, [rasgado] } \\
\text { os [rasgado] que darei são; |uma copia d'esta } \\
\text { carta e |uma medalha com o nome |de meu filho } \\
\text { e o meu - guardarei |uma medalha e a outra igual } \\
\text { |acompanha meu filho }\end{array}$ \\
\hline Protocolo final & $\begin{array}{l}\text { Assinatura } \\
\text { Fecho de cortesia }\end{array}$ & $\begin{array}{l}\text { Cassianna } \\
\text { que fica agradecida e pede la Deus pela } \\
\text { felicidade de todos" }\end{array}$ \\
\hline
\end{tabular}

Agrupamos os escritos que se classificam como carta independentemente de sua extensão ou da presença de todas as partes da estrutura documental.

\footnotetext{
${ }^{105}$ Recorte quadrado com bordas irregulares na parte central do escrito
} 
Nos escritos do tipo $\mathrm{T}_{1}$, há, como partes, um autor (ou autores intelectual e material) e um destinatário, mesmo que não explicitados nos protocolos inicial e final. $\mathrm{Na}$ expositio, os textos apresentam regularidade nas informações básicas em relação ao exposto. As informações compreendem, de forma geral, a data de nascimento, o nome e o batismo da criança. $\mathrm{O}$ autor também pode apresentar justificativas para o abandono do exposto e/ou outras informações que julga pertinentes, como o nome dos genitores, o estado de saúde da criança, a situação financeira da família e outras $^{106}$. Na dispositio, o autor realiza solicitações que se referem ao exposto ou a seu resgate em um momento futuro.

A seguir, examinamos o escrito 2.

Ahi Vaỳ hese Menino Com hidade dehum mes eNove dias Cuyo esta por bautizar eaheste Ihepurão o Nome de Joze theadoro eahi Leva huã Camezinha uzada debertanha e humas Ro

5 pinhas deSeda azul claro Ja uzadas eLeva dois Cuheiros pardos ehum azul ferete Ja Lavados eLeva huma touquinha tambem uzada hoye quarta feira 29 domes de dezembro de1790

e Este esCrito o gardaraõ bem aRecadado porCauza 0 deque Seus pais oquerem tirar Sedo eo Naõ mandará para Lonye

Protocolo inicial

\section{Data tópica}

Data cronológica

Endereçamento

Texto

Expositio

Dispositio hoye quarta | feira 29 domes de dezembro $\underline{\underline{\text { de} 1790}}$

\author{
Ahi Vaỳ hese Menino Com hidade dehum mes | \\ eNove dias Cuyo esta por bautizar eaheste | \\ Ihepurão o Nome de Joze theadoro eahi Leva | \\ huã Camezinha uzada debertanha e humas Ro \\ | pinhas deSeda azul claro Ja uzadas eLeva | \\ dois Cuheiros pardos ehum azul ferete Ja \\ Lavados | eLeva huma touquinha tambem \\ uzada \\ e Este esCrito o gardaraõ bem |aRecadado \\ porCauzal deque Seus pais oquerem tirar Sedo \\ eo Naõ mandará | para Lonye
}

\footnotetext{
${ }^{106}$ Ao lado das informações básicas a respeito do exposto e das circunstâncias de seu nascimento, é possível perceber nos escritos da Roda a presença de diversos elementos de persuasão, que mereceriam uma análise retórica aprofundada. Os autores dos escritos recorrem, em casos específicos e em graus variados, a justificativas para o depósito da criança e a argumentos para o convencimento do destinatário. Segundo Dante Trigali, a persuasão é uma característica imanente a todo texto e "o objetivo de um texto retórico é primordialmente persuadir um auditório, ou um leitor, a aceitar como verdade o que expõe o orador". In: TRINGALI, Dante. Introdução à retórica: a reórica como crítica literária. São Paulo: Duas Cidades, 1988, p. 20.
} 
Protocolo final Assinatura

Neste caso, pode-se notar que o protocolo inicial resume-se à datação cronológica, sem apresentar data tópica ou endereçamento. O escrito não apresenta protocolo final e constitui-se apenas do texto, em que constam as duas partes: a expositio e a dispositio.

Por sua vez, escrito 3, apesar de sua brevidade, contém os mesmos elementos, a expositio e a dispositio, e pode também ser considerado uma carta em sua forma reduzida. Vejamos a transcrição abaixo:

Ainda naõ está b[a]ptizado: pede-se que

se lhe ponha João Cancio: o signal

he este mesmo bilhete.

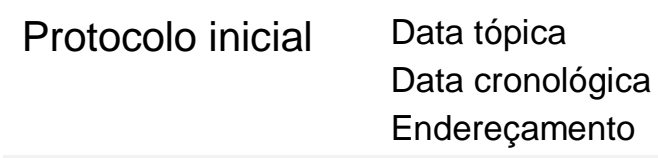

Texto

Expositio Ainda naõ está b[a]ptizado:

Dispositio pede-se quel se Ihe ponha João Cancio: o signal| he este mesmo bilhete.

Protocolo final Assinatura

Fecho de cortesia

Este escrito não possui os protocolos inicial e final. Mesmo assim, apresenta um texto breve, em que se podem observar duas partes: a expositio e a dispositio. Na expositio, o autor narra a circunstância que o levou a redigir o documento, que é o fato de a criança que está sendo depositada não ser batizada e, por isso, não ter nome. Na segunda parte do texto, na dispositio, o autor solicita que o exposto receba o nome de João Cancio e que o destinatário guarde o escrito, para que sirva de sinal, caso o responsável venha buscar a criança.

Do total de 60 escritos do corpus, 54 podem ser considerados como escritos do tipo $\mathrm{T}_{1}$, formando o grupo mais numeroso. ${ }^{107}$

Após a análise dos escritos T1, examinamos os escritos que apresentam uma tipologia textual diversa do ponto de vista diplomático.

\footnotetext{
107 A tiplologia estabelecida para nosso corpus se aplica ao conjunto mais amplo de escritos da Roda consultado no decorrer de nossas pesquisas.
} 


\subsection{ESCRITOS DO TIPO $2\left(\mathrm{~T}_{2}\right)$}

Há um segundo conjunto de escritos que denominamos como escritos do tipo $2\left(\mathrm{~T}_{2}\right)$. Este tipo documental corresponde ao gênero poema. Não se trata, portanto, de uma espécie documental diplomática, mas, sim, de um gênero literário. Definimos poema como uma "obra em verso", que pode ser dotada de "estrofes" e "rimas"108. Trata-se dos escritos 46 e 55.

Vejamos a transcrição do escrito 46:

\|1r|| Não é o crime que aqui expõe Esta pobre criança, innocentinha; Mas de vergonha e lastima pungida <primeira> Com fé, a triste Mãe vôl-a confia: Bôas Irmãs, piedade pra pobresinha.

\|1v $\quad$ _ "Déodato" _ Na Pia seja-lhe este nome dado, que bem exprime sua situação; á Santa Mizericordia confiado $<$ segunda $>$ não faltará ao infeliz protecção.

O escrito 46 corresponde a um poema de duas estrofes, escritas uma de cada lado do suporte. A primeira estrofe compõe-se de cinco versos e a segunda, de quatro versos. A primeira estrofe apresenta rima entre o segundo e o quinto versos. A segunda estrofe apresenta rimas entre o primeiro e o terceiro versos e entre o segundo e o quarto versos. Nota-se também que o nome escolhido para a criança (Déodato) "bem exprime sua situação", nas palavras do autor. Nossa hipótese é que o nome da criança faça referência ao fato de que ela tenha sido "dada" a "Deus".

A seguir, observamos a convergência do gênero textual com outros elementos diplomáticos analisados.

Variação na composição do suporte: Papel amarelo pautado (pauta feita à mão)

Variação no formato do suporte: Suporte com formato de pequeno retângulo com uma das margens arredondadas, semelhante a uma etiqueta.

\footnotetext{
108 Poema sm. "obra em verso' XVIII. Cf. Cunha, A. G., 1982. Definimos "rima" como a "igualdade ou semelhança de sons pertencentes ao fim das palavras, a partir da sua última vogal tônica" e "estrofe" como "grupo de dois ou mais versos". Cf. Bechara. Evanildo. Moderna Gramática Portuguesa, 2006, p. 640-644. Dicionário EtimológicoNarrar vb. 'relatar, contar, expor'1813. || narrative XVII.
} 
Elementos anexados ao suporte: Ilhó inserido no papel

Acréscimos ao texto: não há

A convergência destes elementos permite inferir que o escrito foi produzido intencionalmente em formato de etiqueta, e poderia estar originalmente preso ao exposto ou a uma peça do enxoval do mesmo, por meio de uma fita ou fitilho. A hipótese é reforçada pela presença do ilhó, cuja função seria deixar passar a fita ou o fitilho.

Embora o escrito 46 tenha uma estrutura redacional do tipo $T_{2}$, há partes do texto que têm a função da expositio e da dispositio, como indicamos abaixo.

Protocolo inicial

Texto

Expositio

Não é o crime que aqui expõe |Esta pobre criança, innocentinha; |Mas de vergonha e lastima pungida | Com fé, a triste Mãe vôl-a confia: |

|á Santa Mizericordia confiado | não faltará ao infeliz protecção.

Dispositio

Bôas $\underline{\text { Irmãs, }}$ piedade pra pobresinha.

_ "Déodato" _ Na Pia seja-Ihe este nome dado,| que bem exprime sua situação;

Protocolo final

Vejamos a seguir o escrito 55:

\|1r\| Sã̃ Paulo 21-2-1922

Dôr de Mãe

Filho não posso agasa Ihar-te a vida

Parece que a vida se me vai finar

Quem te pude-se, a ti serafim

Levar junto-a mim, pra a campa finál

A campa eu vou ai depois da morte

Quem sabe a sorte que minha alma tem

Que anceios filho que amor profundo

Vai neste mundo a vida de tua mãe

A todos perdão que me deram tratos

Raça de ingratos ingratidão sem fim

Não choro os dias que eu sonhei serenos

A sepultura ao menos a tudo dará fim 
Se tu Morreres

Vai filho aos anjos te recebam lidos

E guarda os segredos que me ouvis te aqui

E se avistares do Senhor a sede

Por mim lhe pede que eu tambem morri

$\|1 \mathrm{v}\|$ <Se morrer- | mos sem| nos vermos | mais que | deus nos | junte nos Ceus | Adeus | meu | filho | pede a | Deus por | mim | Adeus>109

Vai filho aos anjos que te deram seus cantos

Por estes prantos os meus olhos tem

$\mathrm{E}$ se em mim perdes maternal ternura

A Virgem pura que te seja Mãe

Teu pai rogado por ingloria senda

Que vida orrenda viverá tambem

Sem o distino nosso, mais puder saber

Se foi morrer, seu filho e tua Mãe

Se eu morrer te deixarei somente meu beijo ardente o derradeiro adeus

São os tesouros que eu para ti contenho

Nada mais tendo que oferecer-te os Ceus

[espaço] Fim [espaço]

Pelas chagas de Christo Ihe peço guardarem este pa-

pel junto com o meu filho que eu se deus

me der vida e saude daqui alguns mezes darei

o que eu puder para encontrar meu filho peço não o darem sem que levem uma carta

igual a esta e o retrato tambem

O escrito 55 constitui-se de uma folha que contém uma data cronológica e tópica. A seguir, o autor reproduz dois poemas em sequência, utilizando frente e verso. O primeiro intitula-se "Dôr de mãe" e apresenta 4 estrofes; o segundo tem o título de "Se tu morreres" sendo composto por 3 estrofes.

Não foi possível identificar a autoria dos poemas. Não podemos afirmar tratarse de autor desconhecido, de textos que circulavam na época ou de textos compostos pelo autor do escrito. Após a reprodução dos poemas, encontramos a palavra "fim" e um texto que contém deliberações do autor em relação ao exposto e ao sinal.

\footnotetext{
${ }^{109}$ Escrita no cabeçalho da folha em diagonal.
} 
A seguir, observamos se existe convergência com outros elementos diplomáticos.

Variação na composição do suporte: Papel branco pautado

Variação no formato do suporte: não há

Elementos anexados ao suporte: não há

Acréscimos ao texto: não há

Concluímos que a única particularidade deste escrito é a utilização do papel pautado como suporte.

Embora o escrito 55 tenha uma estrutura redacional do tipo $T_{2}$, é possível reconhecer partes que podemos considerar o protocolo inicial (data tópica, data cronológica e invocação) e uma parte textual que podemos considerar a dispositio.

\begin{tabular}{|c|c|c|}
\hline Protocolo inicial & $\begin{array}{l}\text { Data tópica } \\
\text { Data cronológica } \\
\text { Invocatio }\end{array}$ & $\begin{array}{l}\text { Saõ Paulo } \\
21-2-1922 \\
\text { Pelas chagas de Christo }\end{array}$ \\
\hline Texto & Dispositio & $\begin{array}{l}\text { Ihe peço guardarem este pa- |pel junto com o } \\
\text { meu filho que eu se deus | me der vida e saude } \\
\text { daqui alguns mezes darei | o que eu puder para } \\
\text { encontrar meu filho| } \\
\text { peço não o darem sem que levem uma carta | } \\
\text { igual a esta e o retrato tambem }\end{array}$ \\
\hline
\end{tabular}

Protocolo final

\subsection{ESCRITOS DO TIPO $3\left(\mathrm{~T}_{3}\right)$}

Agrupamos dois escritos da roda que correspondem a narrativas. Utilizamos o termo narrativa com o sentido de "obra em que se conta ou relata algo". ${ }^{110}$ Estes escritos correspondem à fala de um personagem, sem voz no mundo real: o próprio exposto conta a sua história, como se fosse o autor intelectual e material do escrito. Esta forma encontra-se nos escritos 29 e 57.

110, Narrar vb. 'relatar, contar, expor' 1813. || narrativa XVII. Cf Cunha, A. G., 1982. 
A seguir, transcrevemos o escrito 29.

Eu chamo-me Severina, est[ou] baptisada meos Pais são muito pobres minha maÿ acha-se bastante emferma no Hospital é quem me atimen tava, venho hoje, e logo que ela fique restabelecida me virá buscar sou filha de casada, e a anecessidade é grande.

Rio de laneiro 24 de laneiro de 1858

Ao estudar a presença de elementos diplomáticos convergentes, encontramos as seguintes características.

Variação na composição do suporte: não há

Variação no formato do suporte: não há

Elementos anexados ao suporte: não há

Acréscimos ao texto: Desenho de coração na margem superior com texto inserido e desenho de coração duplo na margem inferior com iniciais inseridas.

Nossa hipótese é a de que os acréscimos ao texto reforçam a simbologia da situação familiar descrita nas partes textuais, com o fim de convencer o destinatário da veracidade da mensagem. Na margem superior, o coração representaria a criança e o coração duplo com as iniciais, os pais da criança.

Ao efetuarmos a transposição dos elementos da narrativa e analisarmos como partes do texto, temos o seguinte resultado.

$\begin{array}{cll}\text { Protocolo inicial } & \begin{array}{l}\text { Datação tópica } \\ \text { Datação cronológica }\end{array} & \begin{array}{l}\text { Rio de laneiro } \\ 24 \text { de laneiro de } 1858\end{array} \\ \text { Texto } & \text { Expositio } & \begin{array}{l}\text { Eu chamo-me Severina, est[ou] baptisada| } \\ \text { meos Pais são muto pobres minha maỹ acha- } \\ \text { sel bastante emferma no Hospital é quem me } \\ \text { atimen|tava, venho hoje, } \\ \text { sou filha de casada, el a anecessidade é } \\ \text { grande. } \\ \text { logo que ela fique resta-|belecida me virá } \\ \text { buscar }\end{array}\end{array}$

Protocolo final 
O escrito 57 também apresenta uma narrativa. Cabe ressaltar a utilização do léxico do contexto da criança ("mamãe", "inteirinho" e "gordinho"). A seguir, apresentamos a transcrição do texto.

\section{\|1r\| Recebam-me}

Chamo-me Antonio.

Sou um orphãosinho

de pae, porque elle abando-

nou minha mamãe.

Ella é muito boa e

me quer muito bem, mas

não pode tratar de mim.

Estou magrinho assim

porque ella não tem leite, é muito pobre e precisa

trabalhar.

Porisso ella me poz

aqui para a Irmã Ursula

tratar de mim.

Não me entreguem a nin-

guém porque minha mamãe

algum dia vem me buscar

O meu nome inteirinho

é Antionio Moreira de

Carvalho, e o da minha mãe e

Angelica. Estou com sapinho e com fome.

Minha mamãe não

sabe tratar do sapinho

e não sabe o que me dar

para eu ficar gordinho.

Minha mãe também

agradece dos seus Senhores pelo

bom trato que me derem.

27-6-922 
A seguir, comparamos o texto do escrito com outros elementos diplomáticos estudados anteriormente.

Variação na composição do suporte: Papel branco pautado (folha de livrocaixa)

Variação no formato do suporte: não há

Acréscimos ao texto: não há

O elemento que podemos acrescentar ao texto é o fato de ter sido escrito em uma folha de livro-caixa, um papel que não se destina à elaboração de uma carta. Nossas hipóteses são de que a escolha deste suporte deva-se: a falta de recursos do autor, à falta de interesse em buscar um material adequado para redigir o escrito; à intenção de ressaltar a falta de recursos da criança ou ao fato de que o autor tenha uma atividade relacionada ao comércio.

Embora o escrito 57 obedeça a uma tipologia específica $T_{3}$, podemos dividi-lo em suas partes textuais, como observamos a seguir.

\section{Protocolo inicial Datação cronológica 27-6-922}

Texto Expositio

Chamo-me Antonio.|Sou um orphãosinho | de pae, porque elle abando-| nou minha mamãe.|Ella é muito boa e| me quer muito bem, mas | não pode tratar de mim.| Estou magrinho assim| porque ella não tem leite,| é muito pobre e precisal trabalhar.| Porisso ella me poz | aqui para a Irmã Ursula | tratar de mim.

O meu nome inteirinho | é Antionio Moreira de | Carvalho, e o da minha mãe e | Angelica. Estou com sapinho e I com fome. | Minha mamãe não | sabe tratar do sapinho | e não sabe o que me dar |para eu ficar gordinho. |

Dispositio Recebam-me

Não me entreguem a nin-|guém porque minha mamãe | algum dia vem me buscar |

Protocolo final Fecho de cortesia Minha mãe também |agradece aos Senhores pelo | bom trato que me derem. 
A análise revela que o escrito apresenta-se bastante completo do ponto de vista de sua estrutura redacional, o que revela competência do autor em utilizar a forma narrativa em substituição à forma epistolar.

\subsection{ESCRITOS DO TIPO $4\left(\mathrm{~T}_{4}\right)$}

Bellotto (2002, p.42) lembra que as espécies diplomáticas podem deixar de conter algumas das partes documentais, mas que "todo documento cuja estrutura comporta dados fixos e dados variáveis pode ser submetido à análise diplomática". Os escritos que denominamos $T_{4}$ não possuem as partes documentais mínimas para serem submetidos a uma análise diplomática completa. Trata-se dos escritos 21 e 24. No entanto, comparando-se estes escritos aos outros escritos da roda, é possível concluir que eles relacionam fatos referentes ao exposto. São dados que podem ser considerados elementos de uma expositio rudimentar.

Transcrevemos o escrito 21.

José Bomfim Barbosa

Nascimento.

nascimento 20 Outubro 1959 - 1959

mãe: Gregoria Barbosa

nascimento.

Pae: José Ribeiro

cartorio Campo Grande -

Forte Saõ Pedro -

Legião Brasileira -

Ao analisar as demais variações nos elementos intrínsecos e extrínsecos, observamos o seguinte resultado.

Variação na composição do suporte: Papel amarelo sem pauta (espesso, liso, semelhante a papel-cartão)

Variação no formato do suporte: não há

Elementos anexados ao suporte: não há

Acréscimos ao texto: não há

O único elemento digno de nota é a variação na composição do suporte. Podemos inferir que exista alguma correlação entre a exiguidade dos elementos 
referidos e a estrutura rígida do suporte material; no entanto, trata-se de uma hipótese sem comprovação.

Os dados listados pelo autor podem se constituir em um expositivo rudimentar, como se apresentam a seguir.

\section{Protocolo inicial}

Texto

Dispositio

José Bomfim Barbosa| Nascimento.| nascimento 20 Outubro 1959 - 1959| mãe: Gregoria Barbosal nascimento.| Pae: José Ribeirol cartorio Campo Grande - | Forte Saõ Pedro Legião Brasileira.

Protocolo final

Segue transcrição do escrito 24.

Isabel Cristina Marques

Batisada

Nascida em 18 de Julio de 1961

Amalia Marques

Ainda mais reduzido que o escrito que observamos anteriormente, o escrito 24 arrola apenas o nome, a condição de batismo e a data de nascimento da exposta, incluindo o possível nome da mãe.

Cotejando o escrito com os demais elementos diplomáticos, observamos o seguinte resultado.

Variação na composição do suporte: Papel amarelo sem pauta (espesso, liso, semelhante a papel-cartão)

Variação no formato do suporte: não há

Elementos anexados ao suporte: não há

Acréscimos ao texto: não há

Assim como o escrito 21, que analisamos anteriormente, o escrito 24 também apresenta como única variação a composição do suporte. Seu autor também fez uso de suporte espesso, semelhante a papel-cartão. 
O arrolamento dos dados do exposto podem ser analisados, como uma expositio rudimentar e o nome, colocado no fim do texto, pode ser entendido como uma subscrição.

Protocolo inicial

Texto Expositio Isabel Cristina Marques| Batisada | Nascida em 18 de Julio de 1961|

Protocolo final

$\underline{\text { Amalia Marques }}$

Ao termos concluído o estudo tipológico dos escritos da roda, apresentamos a seguir um quadro-resumo com a classificação tipológica dos escritos da roda de nosso corpus.

Quadro 22 - Classificação tipológica dos escritos do corpus

\begin{tabular}{|l|l|l|l|}
\hline Escritos $\mathbf{T}_{\mathbf{1}}$ & ${\text { Escritos } \mathbf{T}_{\mathbf{2}}}$ & Escritos $_{\mathbf{3}}$ & Escritos $_{\mathbf{4}}$ \\
\hline $1,2,3,4,5,6,7,8,9$, & 46,55 & 29,57 & 21,24 \\
$10,11,12,13,14,15$, & & & \\
$16,17,18,19,20,22$, & & \\
$23,25,26,27,28,30$, & & \\
$31,32,33,34,35,36$, & & \\
$37,38,39,40,41,42$, & & \\
$43,44,45,47,48,49$, & & & \\
$50,51,52,53,54,56$, & & & \\
$58,59,60$ & & \\
\hline
\end{tabular}

É importante ressaltar que embora os escritos da roda apresentem 4 diferentes tipologias, eles contêm as mesmas informações básicas sobre a criança: data de nascimento, nome e se está ou não batizada. Também trazem as vontades e intenções do autor a respeito do exposto e dos sinais com que pretende identificá-lo no momento de seu resgate. Podemos levantar a hipótese de que a escolha de uma tipologia $T_{2}$ ou $T_{3}$ pode ser uma tentativa do autor do escrito tornar sua identidade ainda mais oculta.

A incerteza quanto ao autor intelectual/material dos escritos permanece e relação entre o autor do escrito e o exposto também continua uma questão que a filologia nos oferece diversos recursos para problematizar, mas, pelo anonimato do contexto da roda, não é possível resolver. 


\section{CONCLUSÕES}

As pesquisas realizadas nos acervos da Santa Casa de Misericórdia de Lisboa, da Santa Casa de Misericórdia da Bahia, da Santa Casa do Rio de Janeiro e da Santa Casa de São Paulo permitiram atestar a similaridade da dinâmica de funcionamento das rodas dos expostos e do acolhimento das crianças. Sob uma perspectiva filológica, identificamos características codicológicas e paleográficas do corpus constituído, em que se notou a presença de elementos textuais e não textuais comuns nos escritos.

Da análise diplomática dos 60 documentos manuscritos, que designamos de "escritos da roda", produzidos entre as datas de 1790 e 1969, inferimos seguramente a existência de determinados padrões.

O contexto de anonimato em que os escritos circulavam, revelou-se recorrente por meio de análise dos endereçamentos, das subscrições utilizadas e também pela presença abundante de sinais.

No estudo dos protocolos iniciais, constatamos que a maioria dos escritos (49 escritos) não apresenta um destinatário explícito. Quando o autor dirige-se a alguém, trata-se de um destinatário coletivo, institucional ou indeterminado, o que sugere desconhecimento do destinatário por parte dos autores dos escritos.

No estudo dos protocolos finais, verificou-se que a maior parte dos escritos (40) não apresenta nenhum tipo de subscrição. Entre os escritos que apresentam identificação de autoria, esta é realizada por meio de assinaturas ou rubricas indecifráveis ou apenas com as iniciais do autor. Apenas 4 escritos trazem o nome completo do autor; este fato está diretamente relacionado com a entrega anônima de crianças para a roda.

Dividimos o estudo do texto dos escritos em duas partes principais: a expositio, na qual o autor relaciona os dados referentes ao exposto que considera importantes, e a dispositio, em que o autor manifesta suas vontades e intenções ao destinatário. Nesta parte do texto, os dados mais relevantes referem-se ao nome da criança (53 escritos), data de nascimento (39) e ao fato de a criança estar ou não batizada (37 ocorrências).

De modo geral, verificamos que os autores dos escritos utilizam-se de construções simples, em ordem direta, com o uso das flexões dos verbos nascer, entrar e ir. Outro modo de relatar o depósito da criança na roda consiste no emprego 
dos verbos entregar, remeter, botar e pôr em construções em que o sujeito é o autor do escrito.

A dispositio está explicitada pela utilização dos verbos guardar, buscar, conservar, pedir, procurar, reclamar, rogar e tirar e concerne às solicitações do autor em relação ao exposto e às determinações em relação aos sinais e ao resgate da criança.

A presença de sinais é própria dos escritos da roda; esta foi constatada, abundantemente, nos escritos do corpus, tanto em elementos não textuais como no próprio texto dos escritos. Todos os documentos que apresentavam elementos anexados ao suporte mencionavam textualmente sua presença como sinal. Variações na composição e no formato do suporte, bem como a presença de acréscimos ao texto foram constatadas em um número significativo de escritos. Alguns destes elementos foram referidos pelos próprios autores como sinais, em menções textuais. Nos demais casos, não se pode afirmar conclusivamente que estes elementos fossem sinais.

Em mais da metade dos escritos da roda (35 documentos), o autor referiu-se explicitamente a algum tipo de sinal. O tipo de sinal mais recorrente foi a solicitação da guarda do escrito (13 escritos). Em alguns casos, os autores mencionaram o fato de possuírem uma cópia do escrito; em outros casos, fizeram referência à parte faltante do escrito. Outros sinais bastante mencionados foram as peças de enxoval, descritas em certos casos com abundância de detalhes. Encontramos referências a argolas e medalhas que as crianças eram portadoras, que poderiam servir de sinal de identificação.

Verificou-se que, além das informações básicas a respeito do exposto e das circunstâncias de seu nascimento, é possível perceber que os autores recorrem, em casos específicos e em graus variados, a justificativas para o depósito da criança e a elementos para persuadir o destinatário a atender as suas solicitações a bem tratar o exposto ${ }^{111}$.

A realização do estudo tipológico dos escritos da roda permitiu concluir que grande parte dos escritos da roda corresponde à espécie documental carta, tanto em sua função como "uma forma de transmitir informações e solicitar favores", como também em sua forma, que "diplomaticamente apresenta certa padronização não

\footnotetext{
111 Estes elementos persuasivos mereceriam análise retórica aprofundada, que não foi realizada por não fazer parte do escopo deste trabalho.
} 
obrigatória", com protocolo inicial, texto e protocolo final, conforme lição de Bellotto (2002, p.51-52). Denominamos este agrupamento tipológico como T1. que contempla 54 escritos. Mas, nem todos os escritos correspondem a este padrão tipológico. Denominamos escritos $T_{2}$ os que correspondem ao gênero poema, com 2 ocorrências; e denominamos $T_{3}$ os escritos que correspondem ao gênero narrativa, com 2 ocorrências. Por fim, denominamos $\mathrm{T}_{4}$ os escritos que não possuem as partes documentais mínimas para uma análise diplomática completa, com 2 ocorrências.

Quanto à função dos escritos da roda, a análise comparativa dos escritos da roda, os presentes em nosso corpus e as centenas de outros consultados, revelou que os escritos da roda, mesmo em suas diferenças tipológicas, compartilham de um objetivo comum, qual seja, transmitir ao destinatário informações básicas sobre a criança e expressar vontades e intenções a respeito do exposto e dos sinais com os quais pretende identificá-la no momento de seu resgate. E também apresentar justificativas que visam a comover o destinatário e persuadi-lo a bem tratar a criança.

Portanto, esta regularidade nos escritos da roda revela que mesmo não se tratando de documentos oficiais, os escritos da roda apresentam-se como documentos informais de identificação da criança e que embora não haja uma chancela, tampouco fórmulas divulgadas oficialmente para a elaboração dos escritos das rodas por meio de um manual, até onde se tem notícia, esses escritos apresentam a consolidação de uma parte do que chamamos cultura da roda. 



\section{REFERÊNCIAS}

ALMEIDA, J. S. G. Um estudo sobre o ensino ministrado nas casas dos expostos em educação, às crianças identificadas como pobres, desamparadas e ou abandonadas na cidade de Salvador (1847-1862). Anais do VII Congresso Brasileiro de História da Educação, Cuiabá, 2013.

AMARAL, A. B. do. Dicionário de história de São Paulo. São Paulo: Imprensa Oficial, 2006. p. 548.

ANTUNES, J. F. D. Criação e inserção de expostos na roda de Lisboa na comarca de Torres Vedras no tempo da monarquia constitucional: identidades e percursos de vida. [Dissertação de mestrado em História Moderna e Contemporânea]. Lisboa: Faculdade de Letras, Departamento de História, Universidade de Lisboa, 2014.

ARANTES, E. M. de M. Arquivo e memória sobre a Roda dos Expostos do Rio de Janeiro. Pesquisas e Práticas Psicossociais, v. 5, n. 1, p. 6, São João del-Rei, janeiro/julho 2010.

AZZI, R. (Org). Congregação das Irmãs de São José: educação, saúde e assistência social na Província de São Paulo (1859-1909). Vol. I, São Paulo: Congregação das Irmãs de São José Chambéry, 2012.

BECHARA, E. Moderna Gramática Portuguesa. Rio de Janeiro: Lucerna, 2006.

BELLOTO, H. L. Como fazer análise diplomática e análise tipológica de documento de arquivo. São Paulo: Arquivo do Estado/Imprensa Oficial do Estado, 2002.

BLUTEAU, R. Dicionário da língua portuguesa. 2 vols. Lisboa: Officina de Simão Thadeo Ferreira, 1789.

BRASIL. Decreto n 17.943-A, de 12 de outubro de 1927. [Código de Menores (1927); Código Mello Mattos].

. Decreto-Lei no 2.848, de 07 de dezembro de 1940. Institui o Código Penal. Diário Oficial da União de 31.12.1941 e retificado em 03.01.1941, Brasília, DF.

. Lei $\mathrm{n}^{\circ}$ 8.069, de 13 de julho de 1990. Dispõe sobre o Estatuto da Criança e do Adolescente, e dá outras providências. Diário Oficial da União de 16.07.1990 e retificado no dia 27.09.1990, Brasília, DF.

. Constituição. Constituição da República Federativa do Brasil. Brasília, DF, 1998. Institui o Código de Menores, consolidando as leis de assistência e proteção a menores.

CAMBRAIA, C. N. Introdução à crítica textual. São Paulo: Martins Fontes, 2005.

CARNEIRO, G. O poder da Misericórdia. Vols. I e II. São Paulo: Press Grafic, 1986. 
COIMBRA, A. A. F.; SANTOS, P. M. A.; RODRIGUES, J. P.; CASTRO, M. F.; WYNANTS, H. Ordenações Manuelinas, Livro I, Título LXVII. Do Juiz dos orfãos, e cousas que a seu Officio pertencem. Disponível em: http://www1.ci.uc.pt/ihti/proj/manuelinas/ (acesso em 19 de junho de 2017).

COSTA, M. P. Glossário de termos têxteis e afins. Revista da Faculdade de Letras, Ciências e técnicas do património. Porto, v. III, p. 137-161, 2004.

CUBEIRO, T. M. R. A assistência à infância em Torres Novas: estudo dos subsídios de lactação concedidos pela Câmara Municipal (1873-1910). Dissertação de mestrado em História Contemporânea. Coimbra, Portugal: Faculdade de Letras da Universidade de Coimbra, 2011.

CUNHA, A. G. Dicionário etimológico. Nova Fronteira da Língua Portuguesa. Rio de Janeiro: Nova Fronteira, 1982.

DURANTI, L. Diplomatics: New Uses for an Old Science. Archivaria, Otawa, v. 28, p. 7-27, Summer 1989. (publicado no verão de 1989)

33, p. 6-24, 1991.

. Diplomatics: New Uses for an Old Science (Part III). Archivaria, Otawa, v. . Diplomatics: New Uses for an Old Science (Part V). Archivaria, Otawa, v. 32, p. 6-24, Summer 1991. (publicado no verão de 1991).

FAUSTO, B. História do Brasil. São Paulo: Edusp, 1995.

FAZENDA, J.V. Antiqualhas e Memórias do Rio de Janeiro. RIHGB, Rio de Janeiro, IHGB, v. 149, 1924.

FERREIRA, L. V. A criação de enjeitados em Vila Rica: A permanência da caridade (1775-1850). Dissertação. Univ Fed de Ouro Preto, 2011.

FLECHOR, M. H. Abreviaturas: Manuscritos dos Séculos XVI ao XIX. São Paulo: Editora Unesp, 1991.

FRANCO, R. J. A piedade dos outros: o abandono de recém-nascidos em uma vila colonial, século XVIII. Rio de Janeiro: Editora FVG, 2014. 256p.

HOUAISS, Antônio. Dicionário Houaiss da língua portuguesa. (6 vols.) Lisboa: Círculo de Leitores, 2002 / 03.

Inventário da criação dos expostos do Arquivo Histórico da Santa Casa da Misericórdia de Lisboa. Lisboa: SCML, 1998.

KUHLMANN JÚNIOR, M.; ROCHA, J. F. T. Educação no Asilo dos Expostos da Santa Casa em São Paulo: 1896-1950. Cadernos de Pesquisa, v. 36, n. 129, set./dez., 2006. 
LEANDRO, J. A Roda dos Expostos. Revista Saúde Infantil, v. 33, n. 1, p. 13-14, 2011.

MACEDO, J. M. Luneta Mágica, 1869. Disponível em: $<$ http://www.dominiopublico.gov.br/download/texto/bn000115.pdf $>$ acessado em abril/2017.

MACHADO DE ASSIS. Pai contra Mãe, publicado no ano de 1906 e faz parte da obra Casa Velha. Disponível em: <http://www.dominiopublico.gov.br/download/texto/bv000245.pdf> acessado em abril.2017.

MANOEL, F. D. A voz dos sinais. Cidade Solidária, Lisboa: Santa Casa de Misericórdia de Lisboa, $n^{\circ}$ 15, ano I, 2006, p. 76-85.

.; ANTÃO, N. M. À descoberta do arquivo: roteiro da visita ao Arquivo Histórico da Santa Casa da Misericórdia de Lisboa. SCML, 2010.

$\therefore \quad$. Para além dos silêncios do Arquivo: O acervo da Santa Casa de Misericórdia de Lisboa e a investigação historiográfica. Cidade Solidária, Lisboa: Santa Casa de Misericórdia, nº 24, Ano III, p. 174-194, Julho/2010.

MANOEL, F. D.; COLEN, M. L. G. B. Os expostos e desamparados na Misericórdia de Lisboa. Cidade Solidária, Lisboa: Santa Casa de Misericórdia, Ano II, p. 38-49, 1999.

$\therefore \quad$. O novo arquivo: um espaço de cultura e qualidade. Cidade Solidária, Lisboa, Ano IX, p. 3-11, Julho/2006.

MANOEL, F. D.; MORNA, T. F. Os Expostos da Roda da Santa Casa da Misericórdia de Lisboa. Uma exposição com catálogo. Cidade Solidária, Lisboa: Santa Casa da Misericórdia de Lisboa, nº 7, Ano IV, p. 108-115, 2001.

;

Para além dos silêncios do Arquivo: O acervo da Santa Casa de Misericórdia de Lisboa e a investigação historiográfica. Cidade Solidária, Lisboa: Santa Casa de Misericórdia, nº 24, Ano III, p. 174-194, Julho/2010.

MARQUILHAS, R. A Faculdade das Letras: Leitura e escrita em Portugal no séc. XVII. Lisboa: Imprensa Nacional-Casa da Moeda, 2000.

MEGALE, H.; TOLEDO NETO, S. DE A. (Org.) Por minha letra e sinal: Documentos do Ouro do Século XVII. São Paulo: Ateliê Editorial, 2006.

MESGRAVIS, L. A Santa Casa da Misericórdia de São Paulo (1599-1884): contribuição ao estudo da assistência social no Brasil. São Paulo: Conselho Estadual de Cultura, 1976. (Coleção Ciências Humanas).

MOISÃO, C. Histórias da História: Hospitais Medievais de Lisboa. Parte II. Revista Ordem dos Médicos, 2012, p. 78-82. 
MONTE, V. M. do. Exemplo de descrição codicológica: documentos setecentistas. Revista de Filologia e Linguística Portuguesa, n.10-11, p. 103-120, 2008/2009.

MOURA, V. G. Roda dos meninos expostos: Auto breve de Natal. Lisboa: Quetzal Editores, 1987.

ORLANDI, O. Teoria e prática do amor à criança: introdução à pediatria social no Brasil. Rio de Janeiro: Jorge Zahar, 1985.

PORTUGAL. Código Penal. Lisboa: Imprensa Nacional, 1855.

PAULINO, J. C. V. Os Expostos em Números. Uma análise Quantitativa do Abandono Infantil na Santa Casa da Misericórdia de Lisboa (1850-1903). Atas do IX Encontro Nacional de Estudantes de História, Porto, Universidade do Porto, Faculdade de Letras, Biblioteca Digital, 2014. p. 185-215, eBook.

PINTO, A. J. G. Compilação das providências que a bem da criação, e educação dos expostos ou engeitados se tem publicado, e achão espalhadas em diferentes artigos da legislação pátria, a que acrescem outras, que respeitando ao bom regimen, e economia da sua Administração, e sendo com tudo filhas das mesmas Leis, tem a experiencia provado a sua utilidade. Lisboa: Impressão Régia, 1820.

PUBLIO, C. A. M. Significativos traços do abandono social da criança e do adolescente no Brasil. Cadernos de Ciências Sociais Aplicadas, ano 8, Vitória da Conquista: UESB, $\mathrm{n}^{\circ}$ 12, 2011.

Regulamento para o Serviço dos visitadores. [SCML], Lisboa: Typographia do futuro, 1873.

REIS, M. J. P. Margens sociais. Cidade Solidária. Lisboa: Santa Casa de Misericórdia, Ano XV, p. 153-163, 2012.

REZZUTTI, P. D. Pedro. A história não contada. São Paulo: LeYa, 2015.

RIBEIRO, L. M. A assistência à saúde da infância e filantropia na Bahia: A Liga Baiana contra a Mortalidade Infantil (1923-1937). In: Anais do XIV Encontro Regional da ANPUH-Rio, Memória e Patrimônio; 2010, p. 8.

RIBEIRO, V. A Santa Casa da Misericórdia de Lisboa (Subsidios para a sua História) 1498-1898. Instituição, vida histórica, estado presente e seu futuro. Lisboa: Typographia da Academia Real das Sciencias, 1902.

RODRIGUES, M. J. M; MANOEL, F. D.; DIAS, M. T.; SOEIRO, L. S. Sinais de Expostos: Exposição Histórico-documental. Lisboa: SCML, 1987.

RUSSELL-WOOD, A. J. R. Fidalgos e filantropos: a Santa Casa de Misericórdia da Bahia, 1550-1755. Brasília: Editora da Universidade de Brasília, 1981.

SÁ, I. As idades da Misericórdia de Lisboa: velhos e novos pobres. In: Visitação. 0 Arquivo: Memória e Promessa. Lisboa: [SCML], 2014. 
SANTANA, A. Santa Casa de Misericórdia da Bahia e sua prática educativa; 1862 - 1934. Tese apresentada ao Programa de Pós-Graduação em Educação. Salvador: Faculdade de Educação, Universidade Federal da Bahia, 2008. 230p.

SILVA, D. S. M. Estatuto da criança e do adolescente: por que o ECA não está sendo cumprido? Revista Âmbito Jurídico, Rio Grande, v. 146, Ano XIX, 2016.

SILVA, R. da. A construção do Estatuto da Criança e do Adolescente. Âmbito Jurídico, Rio Grande, II, n. 6, ago 2001.

SOARES, Jô. O xangô de Baker Street. São Paulo: Companhia das Letras, 1995. p. 209-213.

SPINA, S. Introdução à Edótica: crítica textual. São Paulo: Cultrix, 1977.

TESSIER, G. Le Diplomatique. Paris: Presses Universitaires, 1952.

TRINGALI, D. Introdução à retórica. São Paulo: Duas Cidades, 1988.

VENÂNCIO, R. P. Famílias abandonadas: Assistência à criança de camadas populares no Rio de Janeiro e em Salvador - Século XVIII e XIX. Campinas, SP: Papirus, 1999.

. Da Caridade à Filantropia: assistência à infância no Brasil, 1750-1850. Universidade Federal de Ouro Preto, 2008. p. 8-15.

. Infância e Pobreza no Rio de Janeiro, 1750-1808. História: Questões \& Debates, Curitiba, v. 19, n. 36, p. 129-159, 2002. Editora UFPR.

\section{OBRAS CONSULTADAS}

A Bíblia de Jerusalém. São Paulo: Paulinas, 1985.

ACIOLI, V. L. C. A Escrita no Brasil Colônia: um guia para leitura de documentos manuscritos. Recife: Editora Universitária UFPE / Fundação Joaquim Nabuco/Ed. Massangana, 1994.

ALVEZ, M. S. R. A “Casa da Roda" de Cabo Frio no período de 1830 a 1900. Dissertação de Mestrado, Programa de Pós-Graduação em Políticas Públicas e Formação Humana, UERJ, 2009.

ANTONIL, A. J. Cultura e opulência do Brasil por suas drogas e minas. Introdução e notas de Andreé Mansuy Diniz Silva. São Paulo: EDUSP, 2007. 
- Santa Casa de Misericórdia. In: Jacó-Vilela, A. M. (Org.), Dicionário histórico de instituições de psicologia no Brasil. Rio de Janeiro: Imago, 2011.

ARIES, P. História Social da Criança e da Família. trad. Dora Fasksman. 2a . ed. Rio de Janeiro: LTC- Livros Técnicos e Científicos Editora S.A., 1981.

AZEVEDO FILHO, L. A. de. Iniciação em Crítica Textual. Rio de Janeiro / São Paulo: Presença/EDUSP, 1987.

BARROS, J. de. Grammatica da lingua portuguesa. Lisboa: Olyssippone, 1540.

BASSETTO, B. F. Elementos de filologia românica. São Paulo: Edusp, 2005.

BATISTA JUNIOR, J. A vida depois do abandono. Revista Veja. São Paulo, p. 24-27, 22 jun 2016.

BERWANGER, A. R.; LEAL, J. E. F. Noções de paleografia e diplomática. $5^{a}$ edição. Santa Maria: Ed. da UFSM, 2015.

BOSCHI, C. C. Os Leigos e o Poder: Irmandades Leigas e Políticas Colonizadoras em Minas Gerais. São Paulo: Ática, 1986.

BRASIL. Projeto de Lei $n^{\circ} 2.747$, de 2008. Cria mecanismos para coibir o abandono materno e dispõe sobre o instituto do parto anônimo e dá outras providências.

. Projeto de Lei n² 2.834 de 2008. Institui o parto anônimo.

. Projeto de Lei nº 3.220 de 2008. Institui o parto anônimo.

BUARQUE DE HOLANDA, S. Raízes do Brasil. Brasília, Ed. Da UnB: Brasília. (1978), Cobra de vidro. São Paulo, Perspectiva, 1963.

BUCHALLA, A. P. Salvos pela 'Roda'. Revista Veja no 1998, edição 1998, ano 40, n. 9, p. 73, de 7 mar 2007.

BUENO, F. S. Estudos de Filologia. vol 1. São Paulo: Edição Saraiva, 1954.

CARVALHO, C. V. A situação das Santas Casas de Misericórida. Brasília: Câmara dos Deputados, 2005.

CASANOVAS, L. E.; MANOEL, F. D.; COLEN, L. Condições-ambiente do Arquivo Histórico da Santa Casa da Misericórdia de Lisboa. Cidade Solidária. Lisboa - ISSN 0874-2952, n. 19, Ano XI, p. 108-15, 2008.

CASTRO, I. Biblos. Enciclopédia Verbo das Literaturas de Língua Portuguesa. Lisboa: Verbo, 1995.

Introdução à História do Português. Lisboa: Edições Colibri, 2004. 2ª . ed, 
. O retorno à Filologia. In: Miscelânea de Estudos Linguísticos, Filológicos e Literários in Memoriam Celso Cunha. Rio de Janeiro: Nova Fronteira, 1995. p. 511-520.

CHARTIER, R. O Mundo como Representação. Estudos Avançados, v. 11, n. 5, 1991.

CORREIRA, F. S. Origens e formação das misericórdias portuguesas. Lisboa: Livros Horizonte e Misericórdia de Lisboa, 1999.

COSTA, P.S. Ações sociais da Santa Casa de Misericórdia da Bahia. Salvador: Contexto e Arte, 2001.

COSTA, R. F. Um caso de apropriação de fontes textuais: memória histórica da capitania de São Paulo, de Manuel Cardoso de Abreu, 1796. Tese (Doutorado em Filologia e Língua Portuguesa). São Paulo: Faculdade de Filosofia, Letras e Ciências Humanas, Universidade de São Paulo, 2012.

COSTA, R. F. Um livro manuscrito do século XVIII. Revista LINGUAGEM - Estudos e Pesquisas, v. 13, p.123-138, Catalão, 2009.

DURANTI, L. Diplomatics: New Uses for an Old Science (Part II). Archivaria, Otawa, v. 29 , p. $4-17,1990$.

Cunha, C. N. C.; MEgAle, H. A Carta de Pero Vaz de Caminha. São Paulo: Humanitas/FFLCH/USP, 1999.

DE MELO, A. F. de A. e. O papel como elemento de identificação. Lisboa: Biblioteca Nacional, 1926.

DIAS, A. R. B. M. O abandono de crianças na Roda dos expostos da Santa Casa da Misericórdia de Lisboa no século VIII e XIX. Dissertação de mestrado em Psicologia Clínica e Psicopatologia, Instituto Superior de Psicologia Aplicada. 2007. Disponível em http://repositorio.ispa.pt/handle/10400.12/482.

DIAS, E. N. A História, a Codicologia e os Reclames. Revista Histórica, São Paulo, v. 4, p. 1-9, 2005.

DUBY, G. A história continua. Porto: Asa, 1992. p. 25-26.

DURANTI, L. Diplomatics: New Uses for an Old Science (Part II). Archivaria, Otawa, v. 29, p. 4-17, 1990.

. Diplomatics: New Uses for an Old Science (Part III). Archivaria, Otawa, v. 30, p. 4-20, 1990.

. Diplomatics: New Uses for an Old Science (Part IV). Archivaria, Otawa, v. 31, p. 10-25, Winter 1990-91. (publicado no inverno de 1990)

ESCOLAR, H. História do livro em cinco mil palavras. Brasília: INL, 1977. 
ESTEVES, P. L. M. L. Cordialidade e familismo amoral: os dilemas da modernização. Revista Brasileira de Ciências Sociais, Anpocs, v. 36, p. 95-107, 1998.

FACHIN, P. R. M. Práticas de escrita setecentista em manuscritos da administração colonial em circulação pública no Brasil. Tese (Doutorado em Filologia e Língua Portuguesa). São Paulo: Faculdade de Filosofia, Letras e Ciências Humanas, Universidade de São Paulo, 2011.

FÁVERO, L. L.; KOCH, I. G. V. Linguística textual: introdução. São Paulo: Cortez, 1983.

Federação das Santas Casas e Hospitais Filantrópicos do Rio Grande do Sul, Ano V, N. ${ }^{\circ} 22$, Junho, 1999. - Ajuste na data da Santa Casa do Rio de Janeiro (Fonte $\mathrm{GCH})$.

FERNANDES, P. S. À descoberta do Arquivo: um roteiro infantil. Cidade Solidária, Lisboa: Santa Casa de Misericórdia, p. 142-148, 2012.

FONSECA, A. L. C. do A. Exposição ou abandono de recém-nascido: Uma análise da figura elementar do tipo penal. In: Âmbito Jurídico, Rio Grande, XIV, n. 87, abr 2011. Disponível em: <http://www.ambitojuridico.com.br/site/index.php?n_link=revista_artigos_leitura\&artigo_id=9397>.

Acesso em set 2015.

FRANCO, R. J. O órfão na colônia. Revista de História, n. 61, Rio de Janeiro, Biblioteca Nacional, 2010.

. O modelo luso de assistência e a dinâmica das Santas Casas de Misericórdia. Est. Hist., Rio de Janeiro, v. 27, n 53, p. 5-25, janeiro-junho de 2014.

FRAZÃO, F. As cartas de jogar e os expostos da Misericórdia de Lisboa. Cidade Solidária, Lisboa: Santa Casa de Misericórdia, n. 32, p. 140-9, 2014.

GARCIA, R. R. Estudo paleográfico e codicológico dos documentos de Capivari do Século XIX. Revista Filologia e Língua Portuguesa, v. 10-11, p.173-187, 2009.

KHOURY, Y. A. (coord). Guia dos arquivos das Santas Casas de Misericórdia do Brasil: (fundadas entre 1500 e 1900). São Paulo: Imprensa Oficial do Estado de São Paulo, PUC-SP/CEDIC, FAPESP, 2004. Vols. 1 e 2.

LE GOFF, J. Documento/Monumento. In: História e Memória. 2a. Ed. Campinas: Editora da Unicamp, 1992. p. 535-553.

LOPES, P. S. V. O arquivo: Memória e Promessa. Lisboa: SCML, 2014.

MACHADO, A. R.; BEZERRA, M. A. (Orgs.). Gêneros textuais e ensino. $2^{a}$ ed. Rio de Janeiro: Lucerna, 2003. 
;; PASSANHA, M. J.; DINIZ, M. B. Preservar e conservar documentos: O Programa de Conservação e Preservação do Arquivo Histórico. Cidade Solidária, Lisboa: Santa Casa de Misericórdia, Ano IX, p. 74-81, Julho/2006.

MARCILIO, Maria Luiza. História das crianças abandonadas. São Paulo: Ed. Hucitec, 1988.

Paulo, Sept. 1999.

História social da criança abandonada. Rev. bras. Hist. v. 19, n. 37, São

. A Roda dos expostos e a crianção abandonada na História do Brasil. 17261950. In: FREITAS, M. C. (org.). História social da infância no Brasil. São Paulo: Cortez Editora, 2001.

MARCUSCHI, L. A. Gêneros textuais: definição e funcionalidade. In: DIONISIO, A. P., MACHADO, A. R., BEZERRA, M. A. Gêneros textuais e ensino. 5. ed. - Rio de Janeiro: Lucerna, 2007. p. 159.

MARTINS, W. A Palavra Escrita. São Paulo: Ática, 2001.

MATTOSO CÂMARA JR, J. Dicionário de Filologia e Gramática referente a língua portuguesa. 6a ed. Rio de Janeiro: J. Ozon, 1974.

MATTOSO, J. (dir.). História da vida privada em Portugal. A idade moderna. Lisboa: Temas e Debates / Círculo de Leitores, 2011.

MEGALE, H. Filologia Bandeirante. São Paulo: Humanitas, 2001.

MESGRAVIS, L. A assistência à infância desamparada e a Santa Casa de São Paulo: a roda dos expostos no século XIX. Revista de História, São Paulo, v. 52, n. 103, p. 401-423, 1975.

MONTE, V. M. do. Correspondências paulistas: as formas de tratamento em cartas de circulação pública (1765-1775). Tese (Doutorado em Filologia e Língua Portuguesa). São Paulo: Faculdade de Filosofia, Letras e Ciências Humanas, Universidade de São Paulo, 2012.

MORAES, R. B. de. Livros e Bibliotecas no Brasil Colonial. São Paulo: Secretaria da Cultura, Ciência e Tecnologia do Estado de São Paulo, 1979.

MORAES SILVA, A. Diccionario da Lingua Portugueza - recompilado dos vocabularios impressos ate agora, e nesta segunda edição novamente emendado e muito acrescentado, por Antonio de Moraes Silva. Lisboa: Typographia Lacerdina, 1813.

MUNHOZ, R. F. Filologia e discurso na correspondência oficial do Morgado de Mateus: edição de documentos administrativos e estudo das marcas de avaliatividade. Tese (Doutorado em Filologia e Língua Portuguesa). São Paulo: Faculdade de Filosofia, Letras e Ciências Humanas, Universidade de São Paulo, 2015. 
NASCIMENTO, A. C. A sorte dos enjeitados. São Paulo: Annablume, 2008.

NASCIMENTO, A. C. do. Frutos da castidade e da lascívia: as crianças abandonadas no Recife (1789-1832). Estudos Feministas, Florianópolis, v. 15, n. 1, p. 67-83, janeiro-abril 2007.

NOVAIS, F. A. (dir.). História da vida privada no Brasil. São Paulo: Companhia das Letras, 1997, v. 1.

ORTÍ, M. M. C., ed. Vocabulaire international de la diplomatique, 2. ed. Valéncia: Conselleria de Cultura de la Generalitat Valenciana, 1997. Versão online LudwigMaximillians-Universitat München. Disponível em: http://www.cei.imu.de/VID/

OSTOS, P.; PARDO, M. L.; RODRIGUEZ, E. Vocabulario de codicología. Madrid: Editorial Arco/libros, 1997.

PRIORE, M. del. História das crianças no Brasil. (org.) 7. ed. São Paulo: Contexto, 2010, p. 167.

REZZUTTI, P. D. Leopoldina. A história não contada. A mulher que arquitetou a Independência do Brasil. São Paulo: LeYa, 2017.

RUIZ, R. N. Pressupostos Críticos. São Paulo: Imprensa Oficial do Estado, 1965.

SÁ, I. dos G. "Prefácio". Inventário da criação dos expostos do Arquivo Histórico da Santa Casa da Misericórdia de Lisboa. Lisboa: [SCML], 1998.

- Segredos de família: os sinais de expostos entre as práticas de identidade e a construção da memória. In: Os expostos da Roda da Santa Casa da Misericórdia de Lisboa [Catálogo da exposição]. Lisboa: [SCML], 2001.

SANTANA, A. Santa Casa de Misericórdia da Bahia e sua prática educativa (1862 - 1934). Feira de Santana: Editora UEFS, 2012.

SCHNEUWLY, B.; DOLZ, J. Gêneros orais e escritos na escola. Trad. Roxane Rojo. (Org) Glaís Sales Cordeiro. 2a ed. Campinas: Mercado das Letras, 2010.

SCHWARZ, S. Os Cristãos-novos em Portugal no Século XX. Lisboa: Instituto de Sociologia e Etnologia das Religiões, 1993.

SILVA NETO, S. da. Textos Medievais Portugueses e seus problemas. Rio de Janeiro: Acadêmica, 1956.

SOARES, J. M. Memórias para a História da Medicina Lusitana. Lisboa: Academia Real das Sciencias de Lisboa, 1821.

SOARES, U. O passado heroico da Casa dos Expostos. Rio de Janeiro: Fundação Romão Duarte, 1959. 
SOUZA, J. S. de; MIYOKO, M., orgs. Diário da Navegação. São Paulo: EDUSP/ Imprensa Oficial do Estado, 2000.

TEYSSIER, P. História da Língua Portuguesa. Lisboa: Sá da Costa, 1997.

TOVAR, 1944, p. 22 apud SPINA, Segismundo. Introdução à Edótica: Crítica Textual. 2. ed. rev. e atual. São Paulo: Ars Poética, Editora da Universidade de São Paulo, 1994.

TRAVAGLIA, L. C. Sobre a possível existência de subtipos de texto. In: Anais do Congresso Internacional da ABRALIN - João Pessoa 2009, p. 2632-41.

TRINDADE, J. M. B. O abandono de crianças ou a negação do óbvio. Rev. Bras. Hist. vol.19, n.37, São Paulo, Sept. 1999.

VALDEZ, D. Inocentes expostos: O abandono de crianças na Província de Goiás no Século XIX. Inter-ação: Revista da Faculdade de Educação. UFG, v. 29, n.1, p.10729, jan/jun, 2004.

VALERO, C. Normas de publicações: projeto experimental. Bauru: EDUSC, 2000.

VILLALTA, L. C. O que se fala e o que se lê: língua, instrução e leitura. In: História da vida privada no Brasil: cotidiano e vida privada na América Portuguesa. São Paulo: Cia. das Letras, 2002, p. 331-86.

WILKINSON, P.; PHILIP, N. Guia ilustrado Zahar: Mitologia. Rio de Janeiro: Jorge Zahar, 2008.

XAVIER, M. F. Dicionário de termos lingüísticos. Lisboa: Cosmos, 1990.

ZARUR, D. Educandário Romão de Mattos Duarte. Rio de Janeiro: Binus Artes Gráficas Ltda. 2003.

\section{OUTRAS MÍDIAS}

AZEVEDO, Maria Emilia [Cineasta]. Filme de curta-metragem. Roda dos Expostos.

RUY BARBOSA, Benedito [Autor de novela]. Novela Terra Nostra, TV Globo, 20 set 1999-202 jun 2000. 221 capítulos. https://www.youtube.com/watch?v=BwefRJAnCoM

\section{ENDEREÇOS ELETRÔNICOS CONSULTADOS}

BRASIL. Relatórios Ministeriais (1921-1960). http://www.crl.edu/brazil/ministerial. Acesso em 14 de outubro de 2016. 
Código de menores: http://www2.camara.leg.br/legin/fed/decret/1920-1929/decreto17943-a-12-outubro-1927-501820-norma-pe.html. Acesso em 10 de setembro de 2016.

http://academia.gal/destaque-documento/-/asset_publisher/d4TP/content/cartapartida. Acesso em 22 de outubro de 2017.

http://www.dichistoriasaude.coc.fiocruz.br/iah/pt/verbetes/stcasarj.htm. Acesso em 10 de setembro de 2016.

http://www.museudeimagens.com.br/febem-fundacao-estadual-bem-estar-do-menor/. Acesso em 10 de novembro de 2016.

http://www.prefeitura.sp.gov.br/cidade/upload/84b46_02_T_Febem_Sampaio_Viana. pdf. Acesso em 18 de setembro de 2017.

http://www.romaoduarte.com.br/. Acesso em 14 de abril 2014.

http://www.santacasasp.org.br/portal/site/quemsomos/historico. Acesso em 14 julho de 2015.

http://www.scml.pt/pt-

PT/areas_de_intervencao/cultura/arquivo_historico/trabalhos_publicados/. Acesso em 21 de agosto de 2016. 


\section{APÊNDICES}

APÊNDICE A - Abreviaturas utilizadas no corpus

APÊNDICE B - Ocorrências das letras A,D,E,H,P

APÊNDICE C - Variação caligráfica entre os escritos (punhos)

APÊNDICE D - Índice de termos relacionados à exposição de crianças

APÊNDICE E - Índice de termos relacionados aos sinais e ao enxoval

APÊNDICE F - Mais alguns exemplos de escritos da roda (Lisboa e Rio de Janeiro) 
APÊNDICE A - Abreviaturas presentes no corpus

\section{Abreviaturas}

Para análise e compreensão dos manuscritos, no campo da Paleografia, é importante o conhecimento das características das abreviaturas. Realizaremos um estudo das abreviaturas encontradas em nosso corpus, por meio de um levantamento exaustivo, e agruparemos as abreviaturas utilizando a classificação de Flechor (2008, p. XI-XII).

Em períodos mais anteriores da história, o suporte físico era de complexa elaboração e custo dos instrumentos de escrita eram altos. A abreviatura pode corroborar a ideia de restrição, uma vez que o destinatário deve conhecer a formatação da abreviatura. Uma das finalidades das abreviaturas era dar maior agilidade à escrita e permitir maior rapidez dos registros. Como o processo de escrita passou a ser otimizado, atualmente, tanto os diversos suportes materiais como os instrumentos de escrita são mais acessíveis e versáteis, mas, ainda assim se faz uso de abreviaturas.

\section{Classificação das abreviaturas}

Nos documentos luso-brasileiros, Flechor (2008, p.XI) afirma que "não existiam regras de abreviação", e estabelece uma divisão por tipos. Abaixo relacionaremos apenas os tipos que aparecem em nosso corpus.

1) Siglas

a) Siglas simples, indicadas por uma letra apenas

b) Siglas reduplicadas, em que a letra se repete para indicar o plural da palavra abreviada, ou no exemplo abaixo, o superlativo sintético.

c) Siglas compostas, indicadas por duas ou três primeiras letras da palavra ou pelas letras predominantes do vocábulo. Ex.: MOBRAL (Movimento Brasileiro de Alfabetização).

2) Abreviaturas

a) Que tomam como base "sinais gerais". Indicam a abreviação de uma palavra sem indicar qual o elemento que falta. Estas estão dividadas em: 
A1) Por suspensão ou apócope: é quando falta o final da palavra. Ex.: Jub. $=$ Jublilado, Igr. = Igreja.

A2) Abreviaturas por contração ou síncope: é quando falta letra no meio do vocábulo. Ex.: ADS = A Deus, FRZ = Fernandez

A3) Abreviaturas por letras superpostas.

b) Que tomam como base "sinais especiais" que indicam quais os elementos que faltam na palavra abreviada.

Outra forma de abreviar é servir-se da presença de um sinal indicativo dos elementos ausentes. Trata-se das abreviaturas por sinal especial, que se representa por um único exemplo no corpus, mais especificamente na abreviatura da palavra "Lisboa". Vale notar que se utiliza o X por convenção na abreviatura de Lisboa o que não representa o desenvolvimento da palavra. E que se subdividem em:

B1) Sinais de significado fixo: independentemente do lugar em que estiverem colocados. Ex.: hífen ou til colocados em cima de uma letra podem indicar $\mathrm{M}$ ou N, ou ainda, contração de letras como: cõtavão = contavam.

B2) Sinais de significado relativa - isto é, que dependem da letra em que se encontram como $\overline{\mathrm{q}}$ ou $\tilde{\mathrm{q}}$

Flechor (2008, p.XII) comenta que estas formas são mais ou menos fixas, existindo inúmeras variações.

É importante lembrar que a redação dos escritos da roda é uma prática social realizada por muitas pessoas e que nosso corpus abrange escritos de diferentes períodos.

Nos dados do quadro abaixo, a primeira coluna mostra a abreviatura, a segunda apresenta sua correspondência em caracteres de imprensa, a terceira apresenta sua forma desenvolvida e a última coluna indica o número do escrito e da linha em que a abreviatura está localizada. 
a) Abreviaturas por Siglas simples, indicadas por uma letra apenas:

Quadro - Abreviaturas por siglas simples

\begin{tabular}{|c|l|l|l|}
\hline Abreviatura no escrito & \multicolumn{1}{|c|}{$\begin{array}{c}\text { Caracter de } \\
\text { imprensa }\end{array}$} & $\begin{array}{c}\text { Desenvolvimento } \\
\text { da abreviatura }\end{array}$ & Escrito e Linha \\
\hline & $\mathrm{d}$ & $\mathrm{de}$ & 11,6 \\
\hline
\end{tabular}

Em nosso corpus, observamos que há apenas uma abreviatura por siglas simples, relacionadas à palavra de.

Nosso corpus apresentou um total de duas abreviaturas por siglas simples relacionadas às palavras Illustrissimo e Ilustrissima.

b) Abreviatura por suspensão ou apocope

Quadro - Abreviatura por suspensão ou apócope

\begin{tabular}{|l|l|l|l|}
\hline Abreviatura no escrito & \multicolumn{1}{|c|}{$\begin{array}{c}\text { Caracter de } \\
\text { imprensa }\end{array}$} & $\begin{array}{c}\text { Desenvolvimento } \\
\text { da abreviatura }\end{array}$ & Escrito e Linha \\
\hline Cart & Cartório & 21,7 \\
\hline
\end{tabular}

Em nosso corpus, observamos uma ocorrência de abreviatura por suspensão ou apócope, relacionada à palavra Cartório.

c) Abreviaturas por contração ou síncope consistem na supressão de letras do meio da palavra

Quadro - Abreviatura por contração ou síncope

\begin{tabular}{|c|l|l|l|}
\hline Abreviatura no escrito & \multicolumn{1}{|c|}{$\begin{array}{c}\text { Caracter de } \\
\text { imprensa }\end{array}$} & $\begin{array}{c}\text { Desenvolvimento } \\
\text { da abreviatura }\end{array}$ & Escrito o e Linha \\
\hline Sñr & Senhor & 12,1 \\
\hline on & D & Dona & 22,4 \\
\hline
\end{tabular}


Em nosso corpus observamos duas ocorrências de abreviatura por contração ou síncope relacionadas às palavras Senhor e Dona.

d) Abreviaturas por letras superpostas.

Quadro - Abreviaturas por letras superpostas

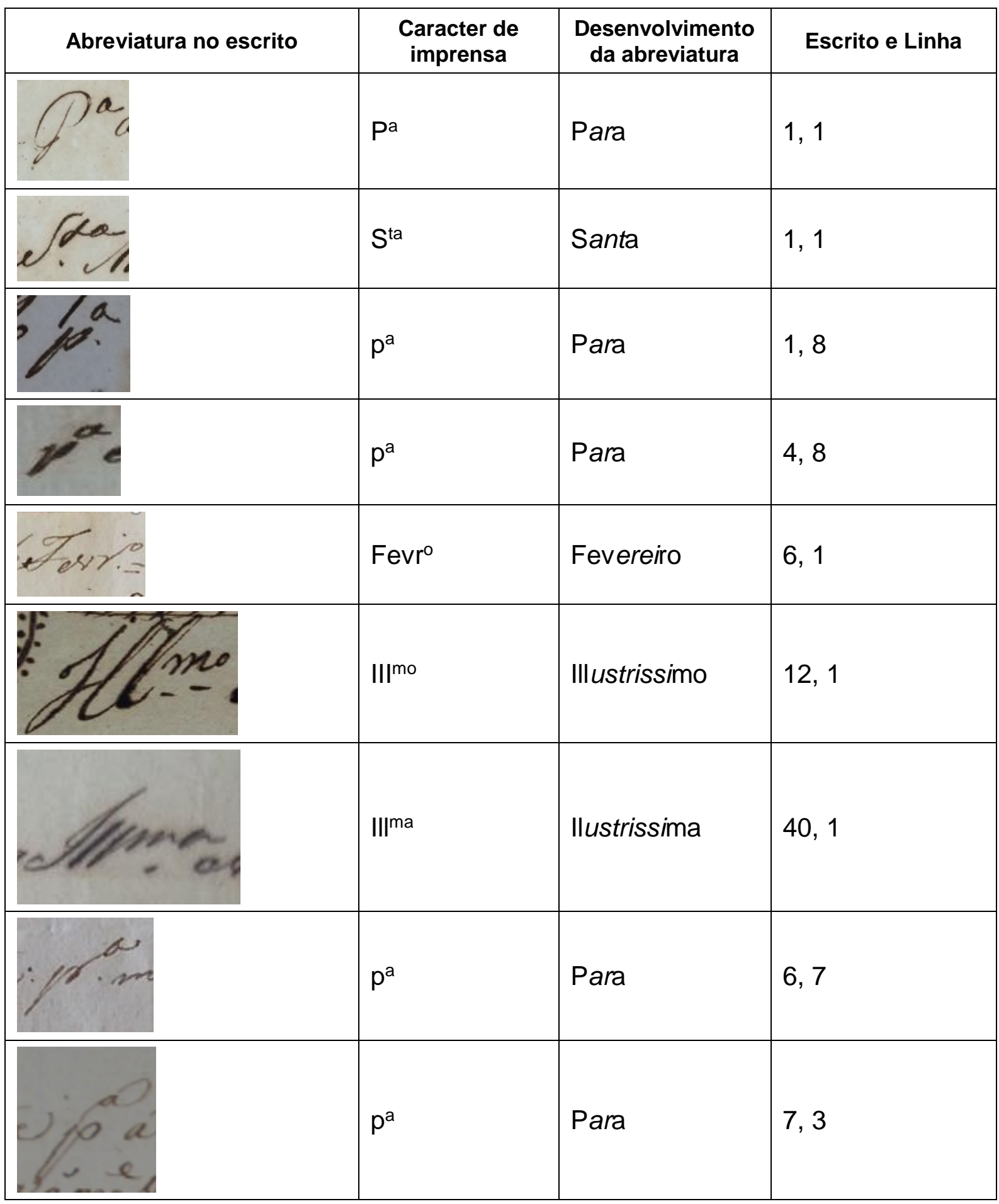




\begin{tabular}{|c|c|c|c|}
\hline & $\mathrm{p}^{\mathrm{r}}$ & Por & 7,7 \\
\hline & $p^{r}$ & Por & 7,7 \\
\hline & $\mathrm{p}^{\mathrm{a}}$ & Para & 7,8 \\
\hline & $S^{\text {to }}$ & Santo & 10,3 \\
\hline & $M^{a}$ & Maria & 11,6 \\
\hline & $\mathrm{p}^{\mathrm{a}}$ & Para & 11,6 \\
\hline & $8 b r^{\circ}$ & Outubro & 12,2 \\
\hline & $\mathrm{St}^{\mathrm{a}}$ & Santa & 13,2 \\
\hline & $\mathrm{St}^{\mathrm{a}}$ & Santa & 13,6 \\
\hline$-1,-\infty$ & $\mathrm{p}^{\mathrm{a}}$ & Para & 15,3 \\
\hline
\end{tabular}




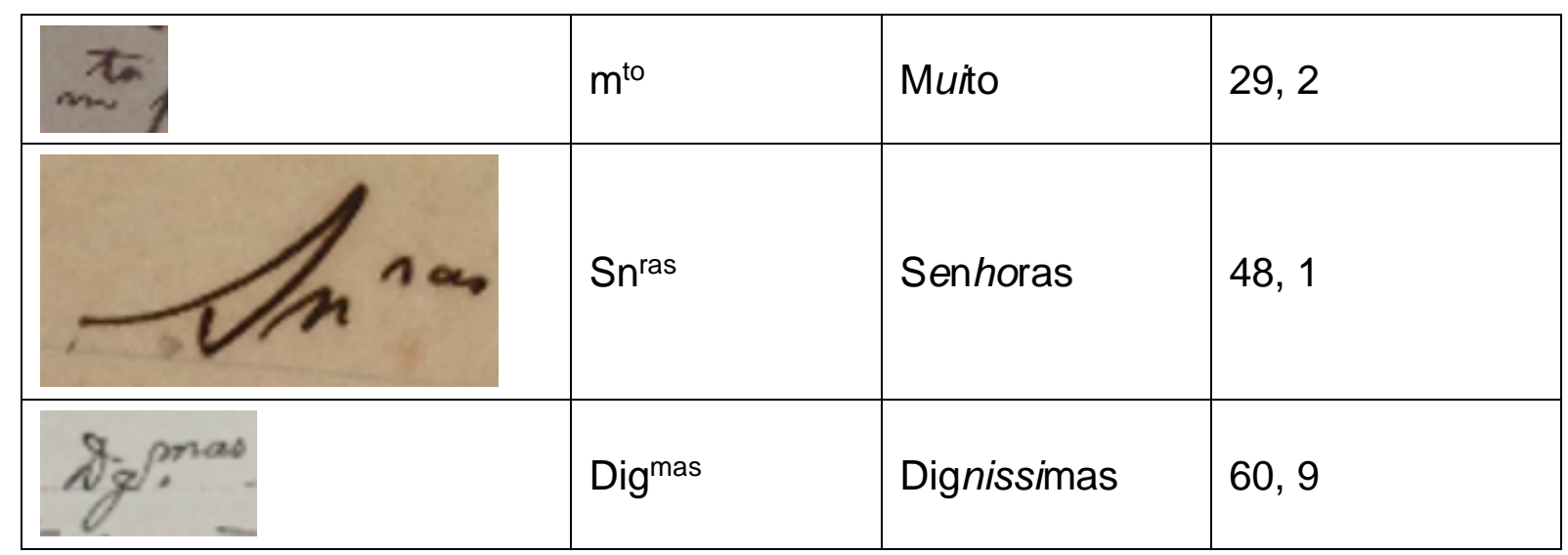

Os escritos de nosso corpus apresentam abundância de abreviaturas por letras superpostas, apresentando um total de 12 ocorrências. Estas relacionam-se às palavras Para, Por, Santo, Santa, Maria, Fevereiro, Illustrissimo, Ilustrissima, Outubro, Muito, Senhoras e Dignissimas.

e) Abrevitaturas por sinais especiais:

Quadro - Abreviatura por sinal especial

\begin{tabular}{|c|c|c|c|}
\hline Abreviatura no escrito & $\begin{array}{c}\text { Caracter de } \\
\text { imprensa }\end{array}$ & $\begin{array}{l}\text { Desenvolvimento } \\
\text { da abreviatura }\end{array}$ & Escrito e Linha \\
\hline & $L x^{a}$ & Lisboa & 1,8 \\
\hline & $\tilde{q}$ & Que & 3,1 \\
\hline & $\tilde{q}$ & Que & 4,9 \\
\hline & $\tilde{q}$ & Que & 7,7 \\
\hline & $\tilde{\mathrm{q}}$. & Que & 11,5 \\
\hline
\end{tabular}




\begin{tabular}{|c|c|c|c|}
\hline$\tilde{4}$ & q. & Que & 11,6 \\
\hline & q. & Que & 11,7 \\
\hline & व. & Que & 15,2 \\
\hline & व. & Que & 15,6 \\
\hline & व. & Que & 41,2 \\
\hline & $\overline{\mathbf{q}}$ & Que & 41,3 \\
\hline
\end{tabular}

Nosso corpus apresenta duas ocorrências de abreviaturas por sinal especial relacionadas às palavras Lisboa e Que.

Verificamos, portanto que os escritos estudados apresentaram um total de 19 abreviaturas. Os dados do quadro a seguir apresentam um resumo de nossos achados.

Quadro - Ocorrências de abreviaturas no corpus

\begin{tabular}{|l|c|l|}
\hline Tipo de abreviatura & $\begin{array}{c}\text { Número total de } \\
\text { ocorrências }\end{array}$ & Abreviaturas desenvolvidas \\
\hline Abreviatura por siglas simples & 1 & de \\
\hline Abreviatura por suspensão ou apócope & 1 & Cartório \\
\hline Abreviatura por contração ou síncope & 2 & Senhor e Dona \\
\hline Abreviaturas por letras superpostas & 12 & $\begin{array}{l}\text { Para, Por, Santo, Santa, Maria, } \\
\text { Fevereiro, Illustrissimo, Ilustrissima, } \\
\text { Outubro, Muito, Senhoras e } \\
\text { Dignissimas }\end{array}$ \\
\hline Abreviatura por sinal especial & 2 & \begin{tabular}{l} 
Lisboa e Que \\
\hline
\end{tabular} \\
\hline
\end{tabular}


Percebe-se, portanto, que as abreviaturas por letras sobrepostas correspondem ao tipo mais utilizado e as abreviaturas por apócope são as menos utilizadas em nosso corpus.

Outros aspectos relevantes do estudo das abreviaturas decorrem da observação sobre os escritos que as contêm. A presença de abreviaturas no texto indica habilidade nos punhos de seus autores, assunto do qual trataremos adiante. Dos 60 escritos do corpus, um total de 17 contém abreviaturas, o que consideramos um número significativo. A seguir reproduzimos um escrito em que a ocorrência de diversas abreviaturas de tipos diferentes é um elemento que demonstra um maior grau de habilidade do punho do autor.

Escrito 11 do corpus da tese

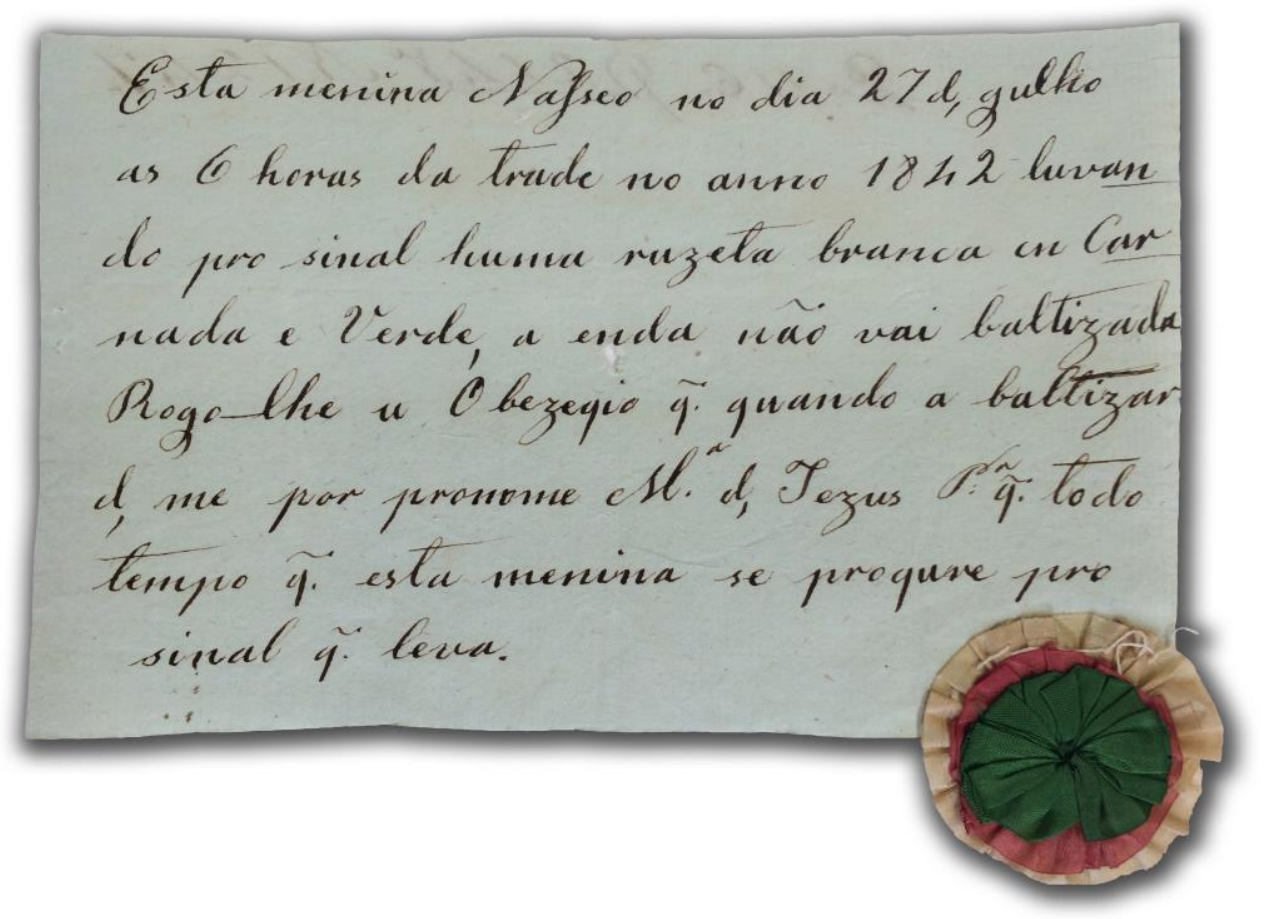

Tendo concluído o estudo das abreviaturas presentes nos escritos do corpus deste trabalho, faremos um levantamento caligráfico dos mesmos. 
APÊNDICE B - Ocorrências das letras A, D, E, H, P e T

\section{Ocorrências das letras A, D, E, H, P e T}

Como mais um dos critérios que colaboram para a identificação dos escritos da roda, empregamos a análise paleográfica. Por meio da análise das caligrafias produzidas nos documentos que compõem o corpus, objetivamos encontrar padrões e, em última instância, identificar da melhor forma os autores materiais dos escritos.

Com esta proposta, apresentaremos neste módulo um levantamento caligráfico exaustivo dos escritos do corpus. Para tanto, partimos da premissa de que todos os escritos do corpus foram manuscritos e apresentam o padrão cursivo, contando com nexos entre os grafemas. Conforme a descrição codicológica aponta, estes manuscritos foram todos produzidos em suporte cartáceo, papel, com instrumentos de escrita que se aproximam dos mais contemporâneos, tais como a caneta tinteiro, a caneta esferográfica ou o lápis.

A seguir apresentaremos um quadro contendo, como exemplos, as ocorrências das letras $A, D, E, H, P$ e $T$ em suas formas maiúsculas e minúsculas de modo exaustivo. Abaixo de cada exemplar consta o número do escrito de onde foi extraída a amostra. 
Quadro - Exemplares de variações caligráficas nos escritos da roda

Amostra exaustiva da letra A maiúscula no corpus

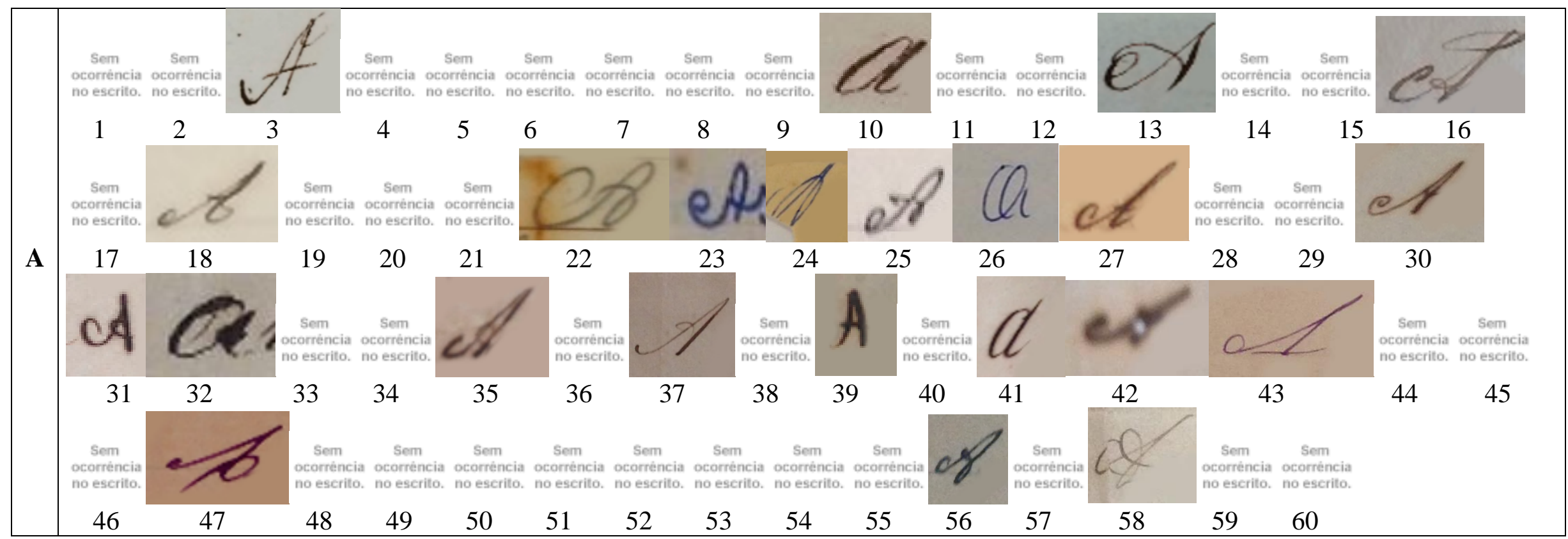


Amostra exaustiva da letra A minúscula no corpus

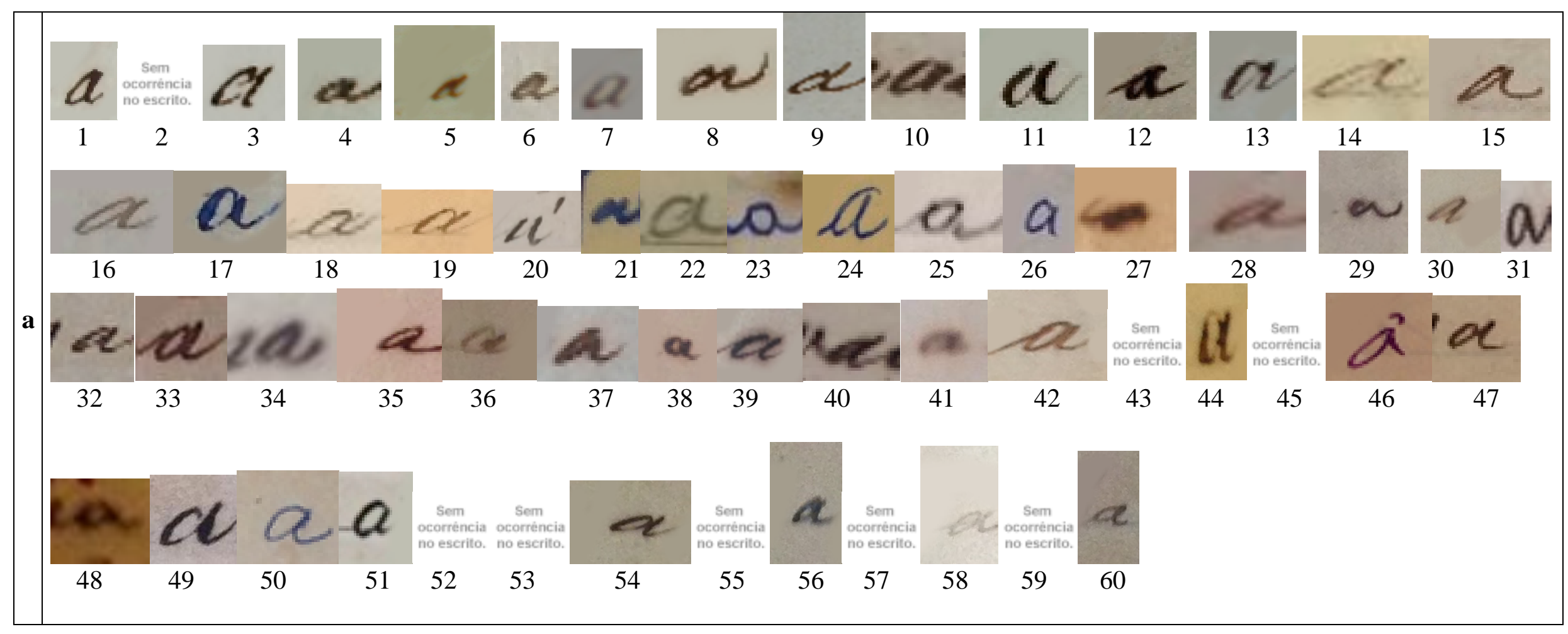


Amostra exaustiva da letra $\mathrm{E}$ maiúscula no corpus

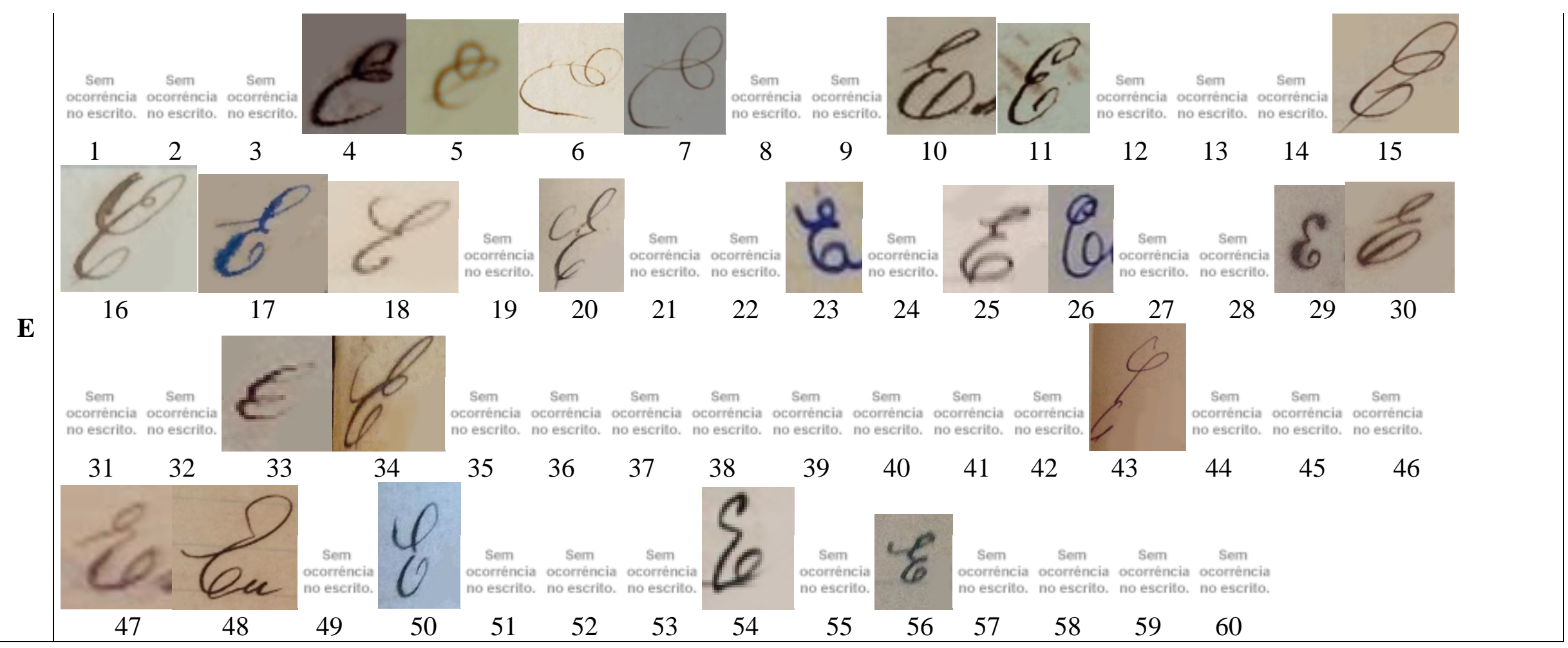


Amostra exaustiva da letra $\mathrm{E}$ minúscula no corpus

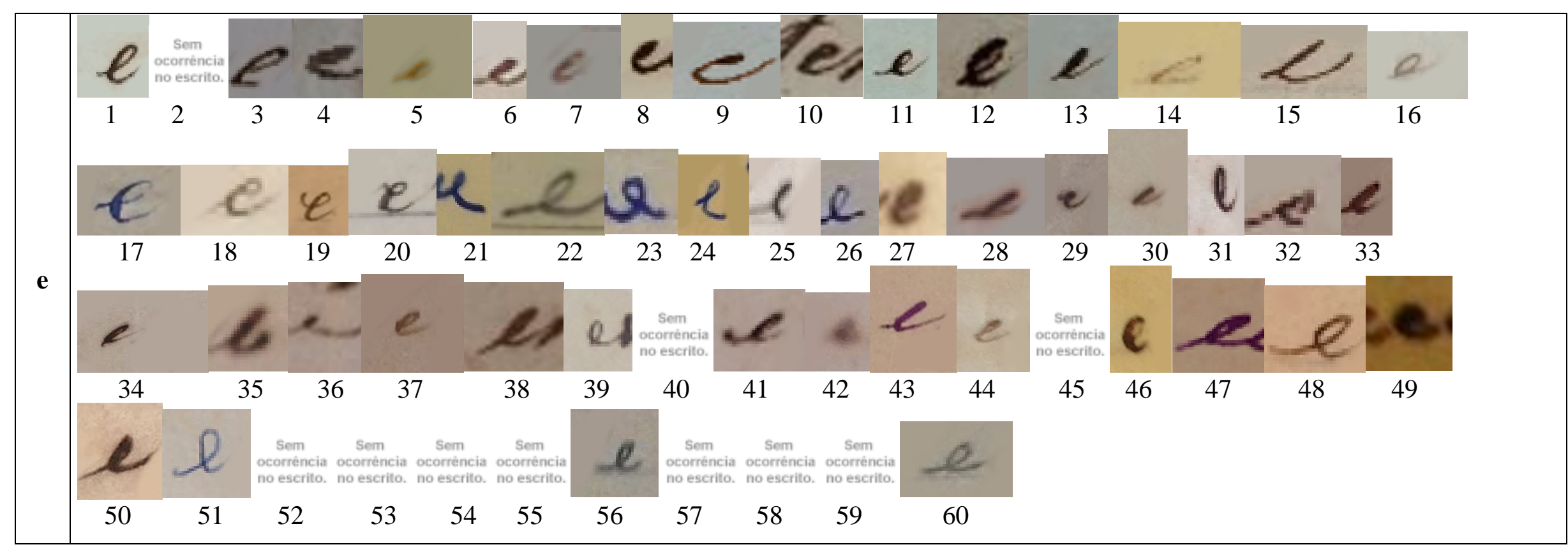


Amostra exaustiva da letra D maiúscula no corpus

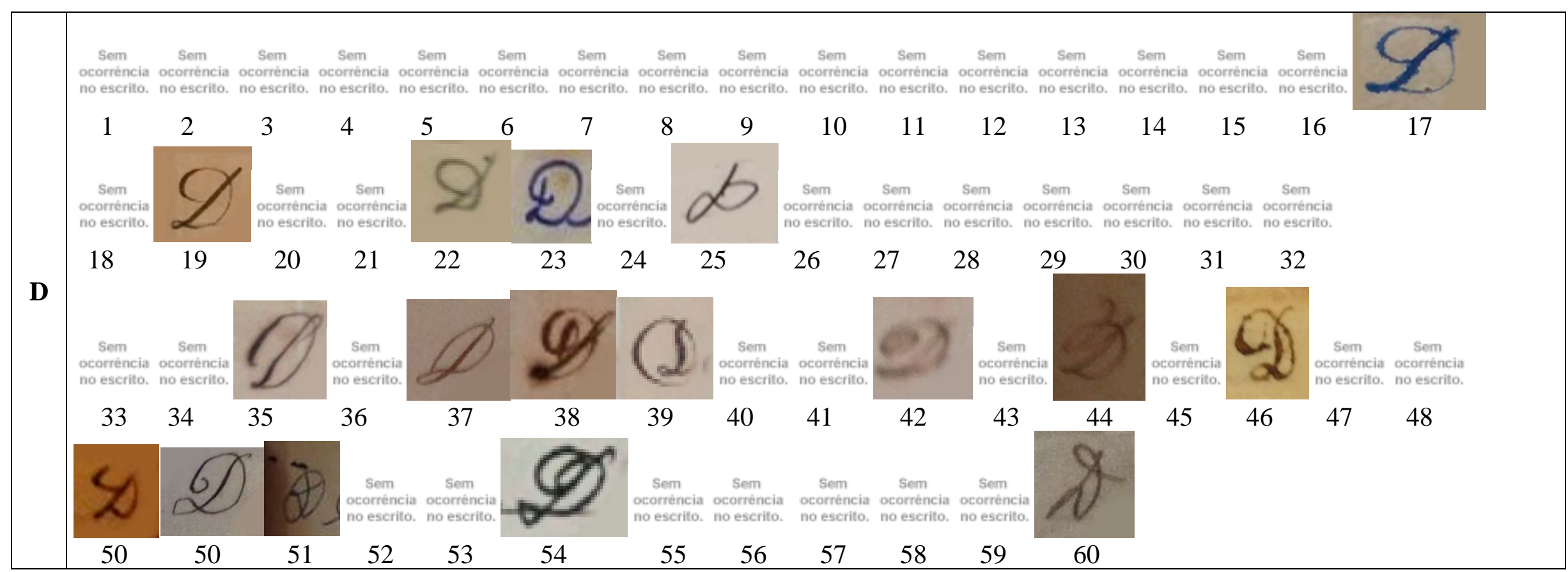


Amostra exaustiva da letra $D$ minúscula no corpus

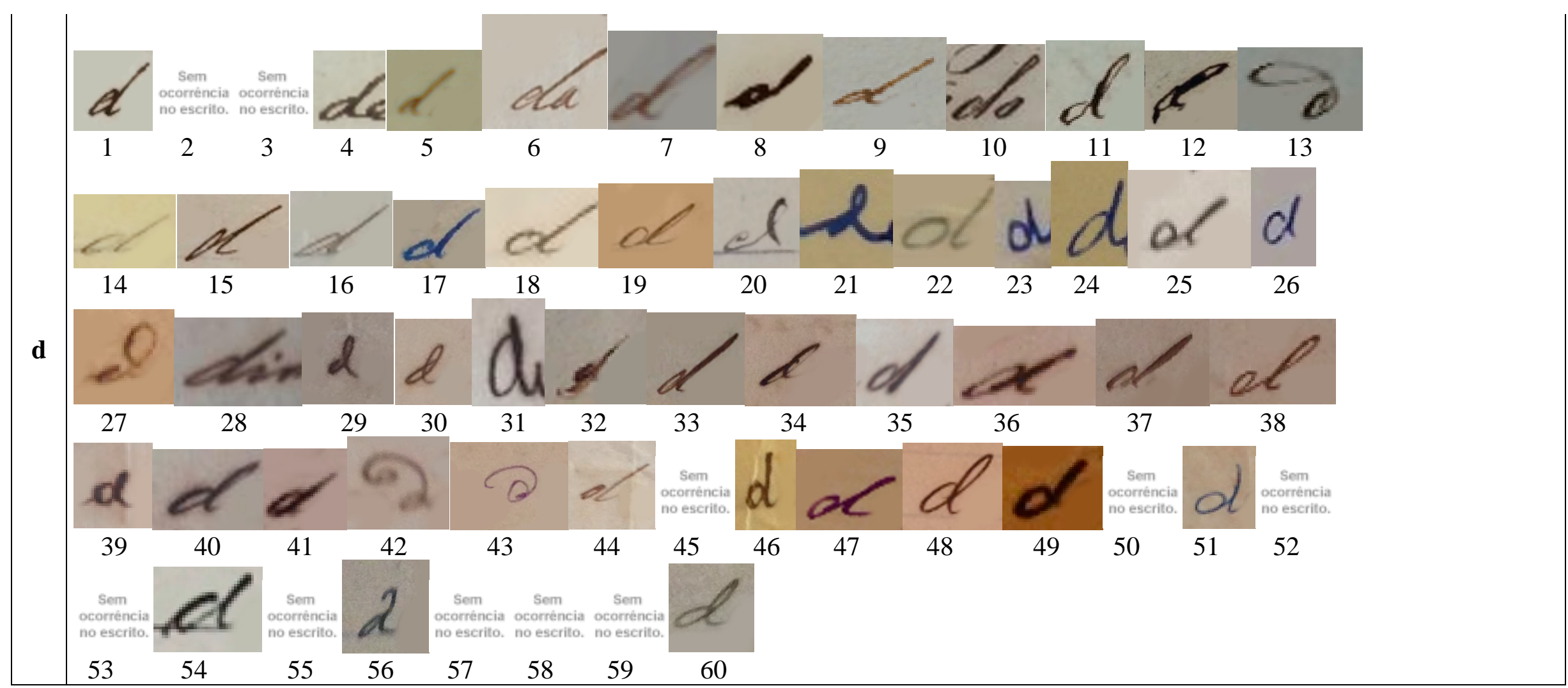


Não há ocorrência da letra H maiúscula no corpus

Amostra exaustiva da letra $\mathrm{H}$ minúscula no corpus

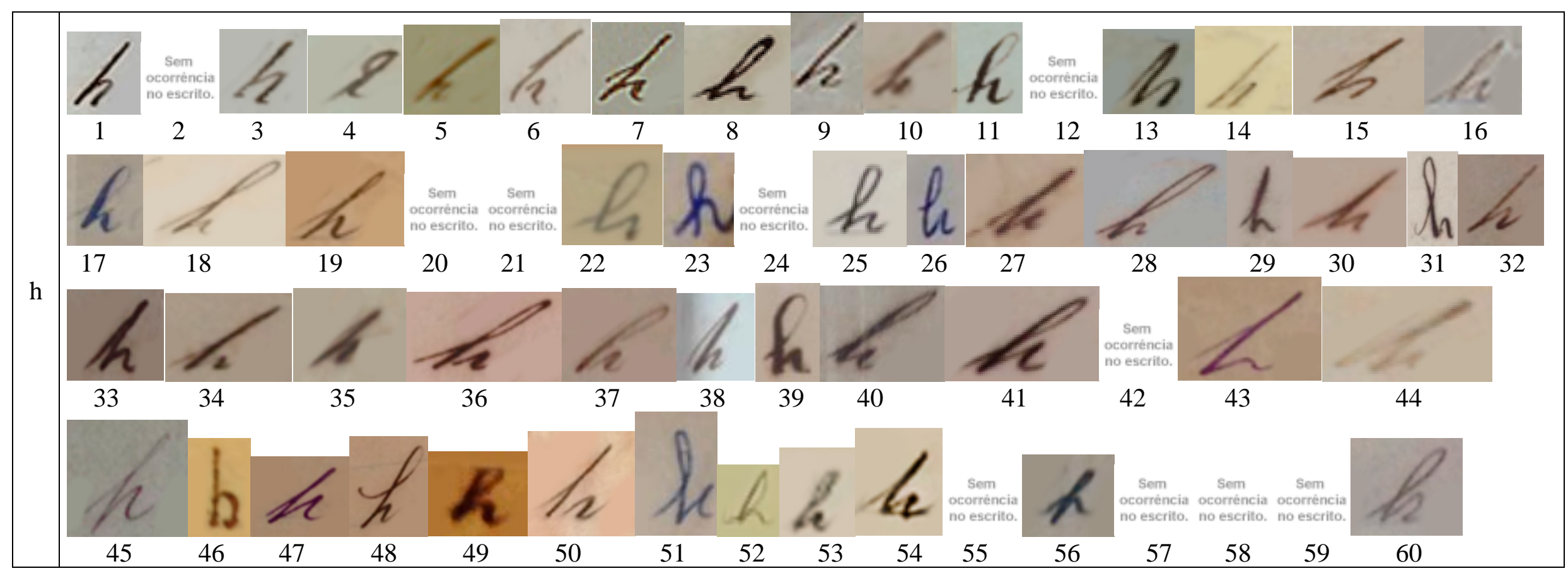


Amostra exaustiva da letra $\mathrm{P}$ maiúscula no corpus

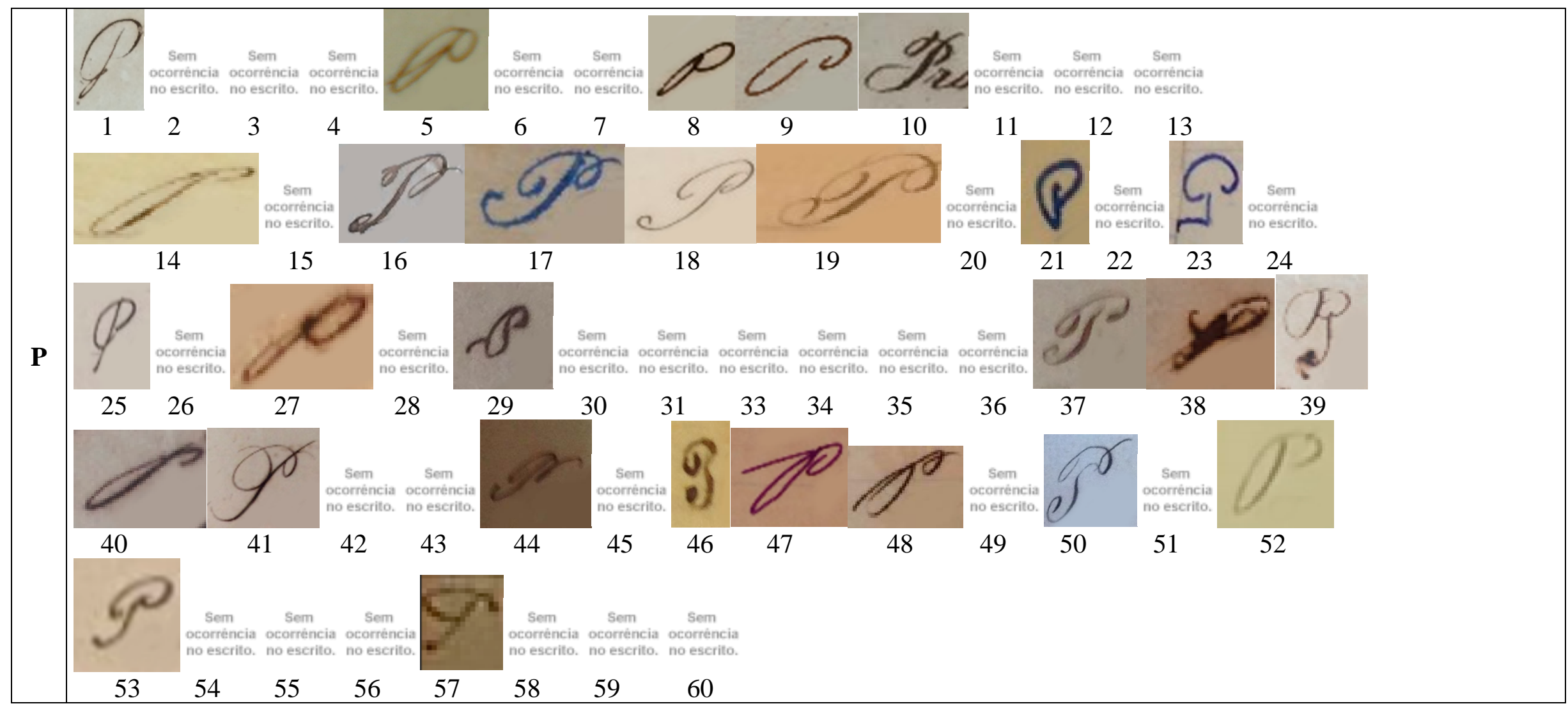


Amostra exaustiva da letra $\mathrm{P}$ minúscula no corpus

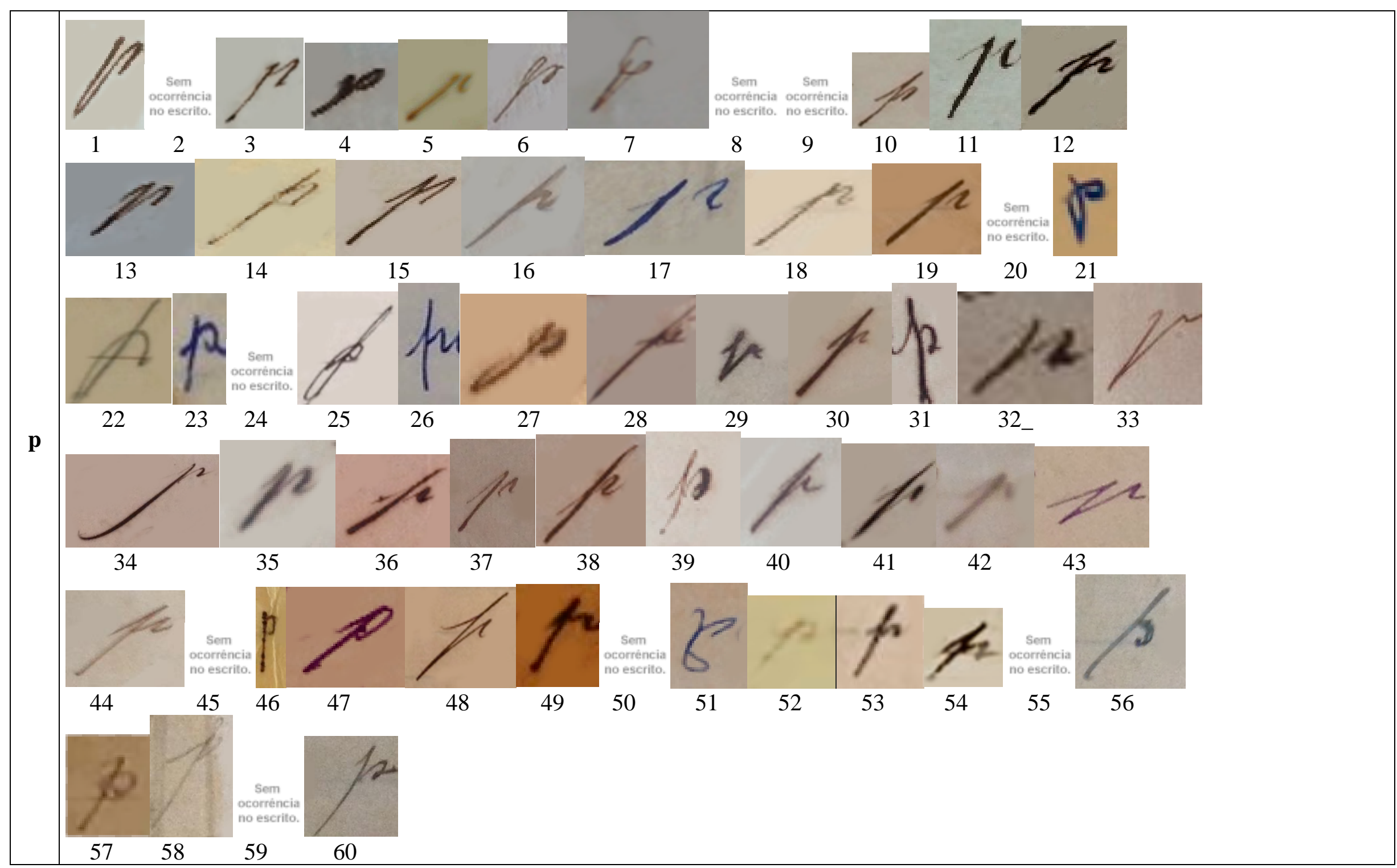




\section{Amostra exaustiva da letra T maiúscula no corpus}

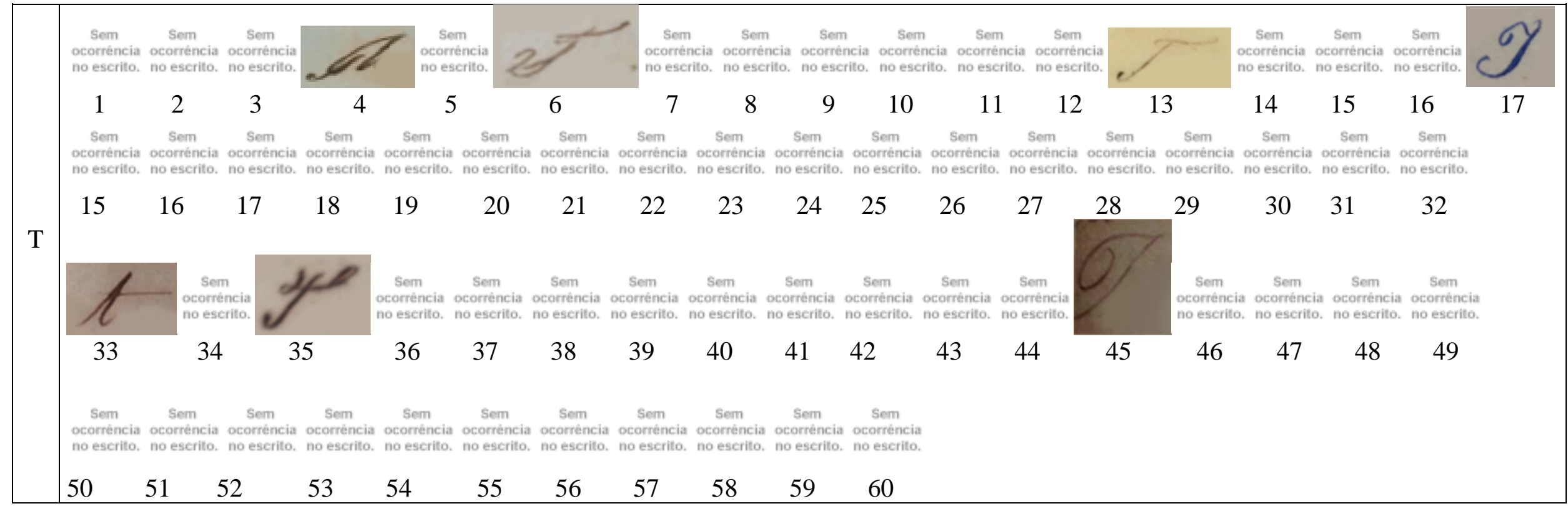


Amostra exaustiva da letra t minúscula no corpus

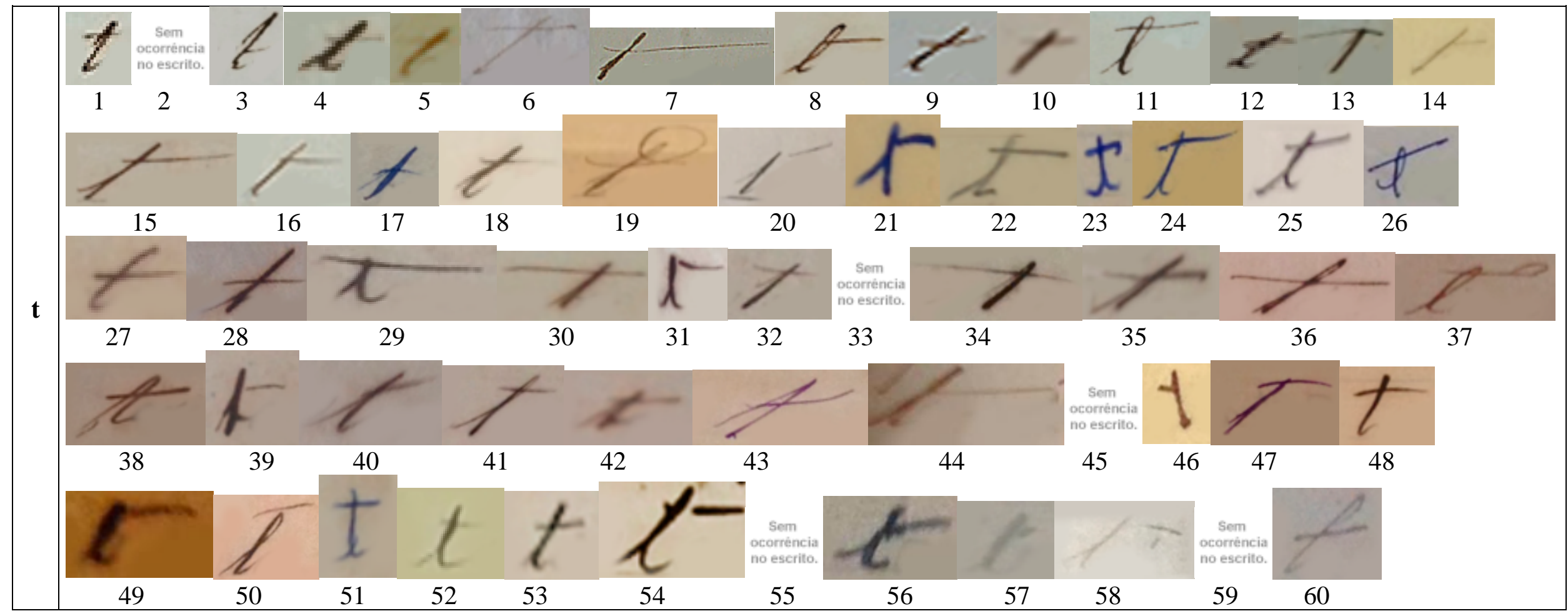



A descrição exaustiva de cada grafema demonstra a similaridade de traçado mesmo se tratando de documentação produzida em épocas distintas, nos séculos XVIII, XIX e XX e por autores diferentes, ou seja, cada escrito é produzido por um autor.

Comparando a inclinação das letras, tanto maiúsculas como minúsculas podemos observar que a maioria das amostras apresenta inclinação à direita. Alguns escritos, porém, revelam letras sem inclinação ou apresentam amostras com inclinação à esquerda, como no caso específico da letra D minúscula.

Podemos concluir que, em relação à A maiúsculo, os escritos 31 e 39 não apresentam inclinação. Já em relação à A minúsculo, as amostras 23, 26, 31, 39, 46 e 49 não apresentam inclinação.

Quanto à vogal E maiúscula, a amostra 54 não apresenta inclinação. Sua forma minúscula não conta com inclinação nas amostras 23, 31, 39, 49 e 51.

Em relação à consoante D maiúscula, as amostras 39, 46 e 51 não apresentam inclinação. O D minúsculo não apresenta inclinação na amostra 49, enquanto as amostras 14, 24, 31, 43 e 44 inclinam-se à esquerda.

A consoante $P$ maiúscula, por sua vez, não se inclina nas amostras 21 e 46 . 0 P minúsculo não apresenta inclinação nas amostras 23, 29 e 43.

Em relação à letra $H$, não encontramos nenhuma ocorrência de sua forma maiúscula no corpus. A letra h em sua forma minúscula não apresentou inclinação nos escritos, 22, 25, 30, 38, 46.

Em relação à letra $T$ maiúscula, o corpus apresentou apenas 7 ocorrências, todas com inclinação à direita. A letra $T$ em sua forma minúscula, por sua vez, não apresentou inclinação nos escritos 39 e 51 e apresentou inclinação à esquerda nos escritos 22 e 45.

Uma análise mais aprofundada destes dados seria necessária em busca de mais informações com relação à autoria dos escritos e da possível utilização de modelos caligráficos. 
APÊNDICE C - Variação caligráfica entre os escritos (punhos)

Entre os escritos da roda, verificamos a ocorrência de diferentes graus de habilidade de punhos.

Conforme Marquilhas (2000, p. 239-40) as seguintes características poderiam servir como indicadores de escritos produzidos por mãos inábeis: ausência de cursus; dificuldade de integrar as letras em um módulo grande; ausência de regramento ideal; traçado inseguro; margens irregulares e combinatória de sinais em contexto inicial, medial ou final.

Manoel e Morna (2001, p.111) afirmam, referindo-se aos manuscritos de Lisboa, que a transmissão das mensagens desejadas pelos autores dos escritos nem sempre atingia o objetivo, pois "o analfabetismo era muito elevado, surgindo textos onde se registravam ideias pouco claras, elaborados com caligrafia não consolidada, ou redigidos com inúmeros erros ortográficos". A seguir, reproduzimos um escrito cujo texto corresponde a estas caracteríscias.

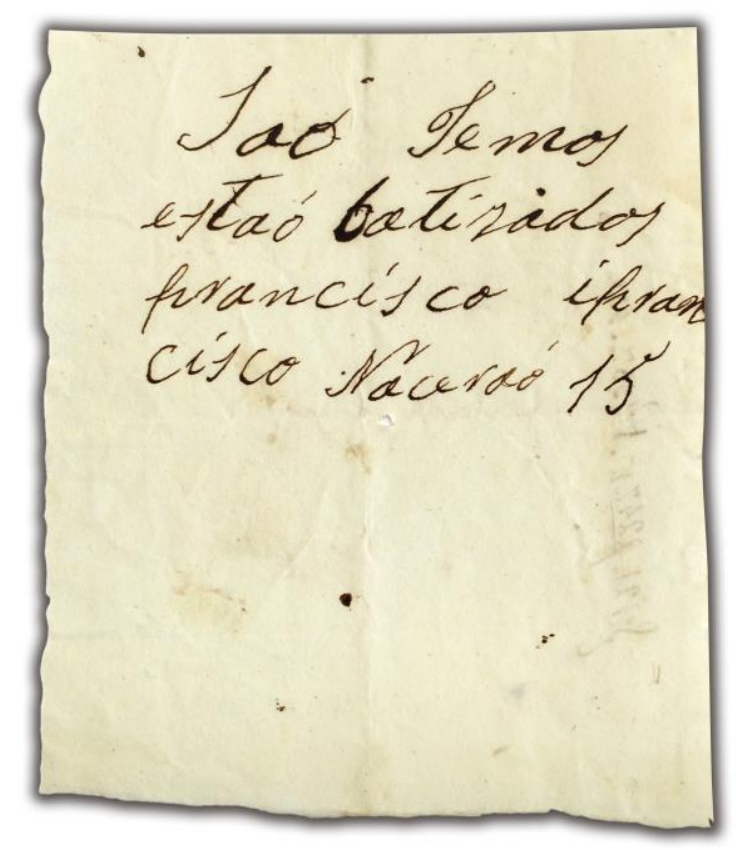

Escrito de Lisboa, 1846

Saó gemos

estaó batizados

francisco ifran

cisco Nascerao 15 
No corpus de nossa tese, não há presença de exemplos claros de graus muito baixos de habilidade de punhos, pois, conforme informado anteriormente, manuscritos com essa característica, na maior parte das vezes, não chegam a configurar um texto e, por isso, no início da coleta, optamos por não incluí-los ${ }^{112}$.

Por outro lado, no entanto, observamos que entre os manuscritos da roda, muitos deles são produtos de mãos com maiores graus de habilidade. Apresentam pautamento regular, obediência às margens, manutenção do curso da escrita, obediência às fronteiras de palavras e emprego adequado de maiúsculas e minúsculas, entre outras características. Os seguintes escritos são exemplos dessas características: $1,7,10,11,13,14,15,19,23,30,46$ e 50.

A variedade de punhos está ligada também à questão da autoria. Há uma grande incerteza sobre a identidade de quem redigia os escritos. Não é possível sequer afirmar que a autoria material corresponda à autoria intelectual dos escritos. É possível, em um primeiro contato com a documentação, até mesmo aventar a hipótese ${ }^{113}$ de que houvesse uma pessoa especializada em redigir esses manuscritos.

\footnotetext{
112 Encontramos exemplares de escritos com punhos inábeis nos arquivos de Lisboa e do Rio de Janeiro. Os escritos do Rio de Janeiro, em razão do modo de encadernação, não puderam ser nem mesmo reproduzidos, como descrevemos no capítulo anterior.

113 Desde o início, esta hipótese não se confirmou em nosso estudo e colaborou à elaboração desta tese, tendo em vista que os padrões regulares de apresentação material, bem como do conteúdo redacional expresso situam os escritos como representações de uma tradição social estabelecida pela existência da roda dos expostos. Essa tradição, contudo, não contava necessariamente com autores materiais profissionais responsáveis por essa produção escrita.
} 


\section{ÍNDICE DE TERMOS DA RODA DOS EXPOSTOS:}

Este glossário de termos específicos do contexto das rodas dos expostos, embora incompleto, pretende ser útil àqueles que venham a trabalhar com o tema. Ele traz o termo pesquisado, o significado do termo e a fonte bibliográfica que nos serviu como referência. 


\section{APÊNDICE D - Índice de termos relacionados à exposição de crianças}

\section{TERMO}

SIGNIFICADO

FONTE

\section{Bilhete}

Mensagem curta, escrita em linguagem simples e coloquial.

HOUAISS, 2002/2003.

\section{Casa da Misericórdia}

Instituição pia, cujos irmãos curão enfermos, casão orfáas, que ahi se educão, crião engeitados.

PINTO, 1820, p. 85.

\section{Casa da Roda}

Em todas as Cidades, e Villas do Reino deve haver Casa de Roda, para expor os meninos, que se enjeitarem, e esta existir em o lugar mais accommodado, que posa haver, em cada huma das Terras, em que devem estabelecer-se; para que mais facilmente se possão expor as crianças, sem serem observados, e conhecidos tão facilmente os seus conductores; procurando-se comtudo, se possível for, hum lugar bem ventilado, e sadío; e huma casa de sobrado, espaçosa, e com as janelas envidraçadas, podendo ser sua conta, e exercita a aseu respeito os direitos, e obrigações, que a Natureza, e as Leis dão aos verdadeiros progenitores (...).

PINTO, 1820, p. 4.

\section{Casa dos expostos}

[vide casa da Roda]

PINTO, 1820, p. 4.

\section{Depositante}

Pessoa que deposita criança na roda dos expostos

Esta tese.

\section{Engeitado}

[vide enjeitado]

PINTO, 1820, p. 3.

\section{Engeitar}

v. at. Não aceitar o que se ofereceu, ou deu v.g. "engeitar o desafio, o serviço, ou presente, o emprego. (símbolo de parágrafo). Tornar ao vendedor, o que se tinha comprado. (símbolo de parágrafo). Expór a criança, o filho. (símbolo de parágrafo). Rejeitar o juiz, reenfar. (símbolo de parágrafo). Engeitar a viagem, não aceitar. (símbolo de parágrafo). Engeitar as inspirações Dividas" H. Pinto. (símbolo de parágrafo). 
enjeita a razão "i. e. reprova. Prov. H. General. T. 6. F. 383. (símbolo de parágrafo). Engeitou-o de parente” Castam. 3. F. 160.

BLUTEAU, 1712. p. 501.

\section{Enjeitado}

Enjeitados ou expostos são aqueles filhos, cujos seus pais enjeitam, e expõem nas

Rodas, ou em outros lugares, para serem criados por caridade. São filhos do Estado.

PINTO, 1820, p. 3.

\section{Enjeitado, e Enjeitar,}

melhor Ortografia que engeitar, segundo a etymologia.

BLUTEAU, 1712. p. 501.

\section{Escrito}

s.m. bilhete breve. (símbolo de parágrafo). Composição por escrito. (símbolo de parágrafo). ------- de obrigação, papel em que ella está lançada.

ESCRITO, part. pass. de escrever

BLUTEAU, 1712. p. 536.

\section{Expor}

v. at. Pór á vista. (símbolo de parágrafo). Por em descoberto, patente v. g., expor ao ar, ao Sol; expor ao perigo, á zombaria. (símbolo de parágrafo) Expòr o Sacramento, i.e. a hóstia consagrada em custodia. (símbolo de parágrafo). Se, oferecer-se,. Fujeitar-se v.g. "expor-se ao perigo, ao exame. (símbolo de parágrafo). Expòr hum passo de algum author.

BLUTEAU , 1712. p. 585.

\section{Exposição}

f. f. o acto de expór, pór à vista, em descoberto, em alvo, por barreira. (símbolo de parágrafo). Declaração, interpretação: explicação.

BLUTEAU, 1712. p. 585.

\section{Expositor}

f.m. o que expõe, interpreta, declara v.g. " os expositores, ou interpretes da Escritura; e fig. As suas obras.

BLUTEAU, 1712. p. 585.

\section{Exposto}

part. Pass. De expor v. exposto á vista; ao Sol, ao ar, ás risadas, e zombarias; arriscado v.g. " - aos golpes, tiros, feridas, perigos. (símbolo de parágrafo). Explicado.

BLUTEAU, 1712. p. 585.

\section{Exposto}

[vide enjeitado]

PINTO, 1820, p. 585 - Vocabulário - Tomo II. 


\section{Facultativo}

Havia um esquema especial para o tratamento dos expostos doentes que ficavam na casa por mais tempo, entregues aos cuidados do facultativo ${ }^{114}$ até que se curassem.

MANOEL \& MORNA, 2001. P 110.

\section{Livro de entrada}

[vide matrícula]

PINTO, 1820, p. 4.

\section{Livro de matrícula}

[vide matrícula]

PINTO, 1820, p. 4.

\section{Livro de receita e despesa}

Alem dos Livros, que devem haver, e são necessários para a Matricula, e entrega dos Expostos ás Amas, haverá outro de Receita, e Despeza, para se lançar nelle em fórma mercantil, tudo o que se houver a bem da Administração, e o que se dispender com ella (...).

PINTO, 1820, p. 39.

\section{Livro de registro}

[vide matrícula]

PINTO, 1820, p. 4.

\section{Matrícula}

1. (...) Ihe fará a sua matricula ou assento de entrada; em que declarará a hora, dia, mez, e anno, em que entrou pela Roda, ou lugar em que fora exposto, e achado; a côr e qualidade de vestidos que trazia; os sinaes externos que o acompanhavão, bem como os internos ou do corpo, que o possão distinguir para o futuro; e se trouxer algum escripto ficará apensado ao mesmo assento, para servir depois de identidade á sua reclamação ou justificação do próprio, e legitimação dos Pais, e no mesmo assento se declarará o dia, mez, e anno do seu Baptismo, por quem foi baptizado, quem forão seus Padrinhos, e que nome se lhe deu; cujo termo será assignado pelo Magistrado Presidente da Camera, ou por quem servir de Administrador, e pelo Escrivão ou Secretario, que o lavrou. Neste mesmo livro de matricula ou entrada, não sendo grande a afluência dos Expostos, se lançarão os termos de entrega ás Amas, reservando-se para cada Expostos nove ou dez folhas do livro, não só para os termos de remoção de humas para outras Amas (quando não for conveniente, que esteja sempre em a mesma Ama), mas para os assentos dos pagamentos até a idade de sete anos; sem fazer diferença de ser de leite ou de secco, como se costuma fazer nas grandes Casas d'Expostos; e no mesmo livro se fará seguidamente o assento do seu falecimento, ou de sua reclamação, ou entrega a seus Pais; achando-se deste modo reunidas em hum só lugar todas as clarezas, que se pretenderem de qualquer Exposto.

2. "Em muitas cidades de Portugal, apezar de tão latos privilégios, não existiam ródas, Em Aveiro, Penafiel e Alemquer fazia-se uma espécie de feira, onde

\footnotetext{
114 Facultativo era o médico responsável por acompanhar o tratamento dos expostos doentes.
} 
apareciam as recoveiras, afim de levar as crianças para as Rodas das terras mais ricas, havendo até algumas Camaras que pagavam as taes recoveiras, livrando-se assim do encargo de ter ródas."

1. PINTO, 1820, p. $18-19$

2. FAZENDA, 1924, p.397.

\section{Matrícula}

(...) Ihe fará a sua matricula ou assento de entrada; em que declarará a hora, dia, mez, e anno, em que entrou pela Roda, ou lugar em que fora exposto, e achado; a côr e qualidade de vestidos que trazia; os sinaes externos que o acompanhavão, bem como os internos ou do corpo, que o possão distinguir para o futuro; e se trouxer algum escripto ficará apensado ao mesmo assento, para servir depois de identidade á sua reclamação ou justificação do próprio, e legitimação dos Pais, e no mesmo assento se declarará o dia, mez, e anno do seu Baptismo, por quem foi baptizado, quem forão seus Padrinhos, e que nome se Ihe deu; cujo termo será assignado pelo Magistrado Presidente da Camera, ou por quem servir de Administrador, e pelo Escrivão

ou Secretario, que o lavrou. Neste mesmo livro de matricula ou entrada, não sendo grande a afluência dos Expostos, se lançarão os termos de entrega ás Amas, reservando-se para cada Expostos nove ou dez folhas do livro, não só para os termos de remoção de humas para outras Amas (quando não for conveniente, que esteja sempre em a mesma Ama), mas para os assentos dos pagamentos até a idade de sete anos; sem fazer diferença de ser de leite ou de secco, como se costuma fazer nas grandes Casas d'Expostos; e no mesmo livro se fará seguidamente o assento do seu falecimento, ou de sua reclamação, ou entrega a seus Pais; achando-se deste modo reunidas em hum só lugar todas as clarezas, que se pretenderem de qualquer Exposto.

PINTO, 1820 p. 18-19.

\section{Recoveira}

Indivíduo que transportava o exposto e que tinha por obrigação entregá-lo a outrem.

MANOEL \& MORNA, 2001. P 110.

\section{Roda da misericórdia}

[vide casa da Roda]

Roda dos enjeitados

[vide casa da Roda]

Roda dos expostos

[vide casa da Roda]

Roda dos inocentes

[vide casa da Roda] 


\section{Rodeira}

1. Em cada uma das Rodas haverá uma rodeira ou mulher, que de dia, e de noite vigie a entrada dos expostos, e dê logo parte ao magistrado da terra, ou administrador da Roda da sua entrada.

2. A Rodeira terá a obrigação de receber a toda a hora do dia, e da noite os Expostos, que se apresentarem na Roda, e de logo os aleitar, tendo ella leite; e não o tendo, nem havendo na Casa Ama ou Criada de leite, de procurar ou fazer procurar in continenti huma mulher, que possa aleitar (...)

1. PINTO, 1820 p. 8.

2. PINTO, 1820 p. 9.

\section{Sinal}

Qualquer coisa da qual vimos em conhecimento de outra com que ella tem connexão natural.

BLUTEAU, 1712, p. $402-$ Vol II.

\section{Termo de entrega do Exposto}

O assento ou termo de entrega do Exposto á competente Ama deve conter o dia, mez, e anno em que se faz, o nome do Exposto, a sua idade, os vestidos que leva, e estado deles, o nome, e sobrenome da Ama, e do Marido, sendo casa, a sua naturalidade, quanto fica vencendo por mez, e até que idade o deve criar de leite, o nome, e sobrenome do Fiador (que se exigirá ás Amas desconhecidas); declarando-se nelle também o estado, em que se lhe entrega o Exposto, e obrigando-se a Ama a criallo com todo o desvelo, e cuidado, e a dar conta dele vivo, ou morto com certidão autentica, em que se declare a moléstia, de que faleceo; devendo por isso assignallo, sabendo escrever, e não sabendo, outra pessoa a seu rogo, e o Abonador, se o houver, o Administrador, e Escrivão.

PINTO, 1820 p. 19-20.

\section{Visitador}

Cumpre ao visitador: Visitar os expostos de qualquer idade até os 18 annos, na divisão que Ihe fôr designada, pelo menos uma ve por mez, mencionando no logar do certificado ou livrete do exposto o dia em que o visitou e o estado em que foi encontrado, devendo ser feita esta visita das 9 horas da manhã at e ás 7 horas da tarde nos mezes de março a agosto, e das 10 horas da manhã ás 5 horas da tarde nos mezes de setembro a fevereiro. (...).

Regulamento para o Serviço dos Visitadores, Lisboa: Typographia do Futuro, 1873, p. 5. 
APÊNDICE E - Índice de termos relacionados aos sinais e ao enxoval

\section{TERMO}

\section{SIGNIFICADO}

FONTE

\section{Algodão}

(esp. gossypium herbaceum ou gossypium arboreum) Planta têxtil, proveniente da Índia, do Egipto e da Espanha.

COSTA, 2004, p. 137-61.

\section{Alvadio}

Alvacento; esbranquiçado; quase branco

HOUAISS, 2002/2003.

\section{Apertador}

Que ou aquilo que aperta

HOUAISS, 2002/2003.

\section{Atadeira}

Que serve para atar

HOUAISS, 2002/2003.

\section{Baeta}

Tecido de lã, grosseiro e felpudo. // Tecido grosso de algodão.

COSTA, 2004, p. 137-61.

\section{Baetão}

Tecido de pano muito grosso, próprio para capotes e saias. // Cobertor de lã

COSTA, 2004, p. 137-61.

\section{Baetilha}

Baeta fina, ligeira, espécie de flanela. // Tecido felpudo de algodão.

Variação presente nos escritos: Beitilha [Coeiro de]

COSTA, 2004, p. 137-61.

\section{Barrete}

Cobertura de tecido flexível que se ajusta facilmente à cabeça e termina em ponta que pende para trás ou para o lado.

HOUAISS, 2002/2003.

\section{Bertangil}

Tecido de algodão que se usava, antigamente, na África e na Ásia. Pano de algodão, azul, preto ou vermelho, produzido pelos cafres.

Variação presente nos escritos: Bretanha 


\section{Bobinete}

(fr. bobiné). Nome antigo de certa espécie de tule.

COSTA, 2004, p. 137-61.

\section{Bocado}

Quantidade de alimento que cabe na boca. Boa porção. Certa quantidade.

Parte do freio que entra na boca das cavalgaduras

HOUAISS, 2002/2003.

\section{Brocado}

Tecido ricamente decorado por tecelagem de fios de ouro e prata. O termo não tem significação técnica, mas é tradicional em documentos antigos sobre tecidos.// Tela entretecida de fios de ouro de várias espécies. A qualidade mais preciosa é a que tem recamo de ouro relevado e se diz brocado-de-três-altos. // Bordado como brocado. //Tecido com figuras, geralmente elementos vegetalistas estilizados, em que o fundo é um desenho simples e as figuras resultam de grupos de alinhavos de teia ou de trama presos de modo conveniente, mas sem uma ordem préestabelecida. Também, se podem usar fios de ouro ou prata (brocados antigos), mas, por razões de ordem prática, torna-se necessário utilizar um tear tipo Jacquard.

COSTA, 2004, p. 137-61.

\section{Caça}

Ação de caçar, de perseguir e matar animais silvestres. Nome genérico dos animais que vão ser caçados ou que o foram; caçada: ir à caça, trazer a caça. [Figurado] Perseguir alguém com o intuito de prender ou matar; perseguição.

HOUAISS, 2002/2003.

\section{Cambraia}

Tecido fino e transparente de linho ou algodão, primitivamente fabricado em Cambraia (França). // Espécie de tarlatana gomada, usada como entretela no vestuário.

COSTA, 2004, p. 137-61.

\section{Cambraínha}

Espécie de cambraia de qualidade um pouco superior à cambraieta.

COSTA, 2004, p. 137-61.

\section{Camisola}

Camisa comprida de dormir.

HOUAISS, 2002/2003.

\section{Chita}

(hind.) - Tecido de algodão estampado a cores. O mesmo que calico.

COSTA, 2004, p. 137-61.

\section{Coeiro}

$$
\text { v. cueiro }
$$

BLUTEAU, 1712, p. 282 - Vol I. 


\section{Cotelê}

(fr.) O mesmo que bombazina. Tecido de veludo de seda ou algodão com sulcos muito profundos (canelados) na face do direito, no sentido da teia (vertical). Muito resistente, usa-se para vestuário prático.

COSTA, 2004, p. 137-61.

\section{Cueiro}

panno, de cobrir, e encachar os meninos,

BLUTEAU, 1712, p. 353, Vol I.

Pano que serve para envolver as nádegas e pernas das crianças recémnascidas.

HOUAISS, 2002/2003.

\section{Debuxo}

(cast. dibujo) Desenho ou estampa. // Peça das fábricas de estamparia, lavrada em relevo ou vazada, sobre a qual se aplicam os corantes ou tintas para estampar os desenhos nos tecidos, sobretudo nas chitas.

Variação presente nos escritos: debruado por debuxado

\section{Esmola}

COSTA, 2004, p. 137-61.

o que fe dá por caridade ao pobre,ou necrflitado.

BLUTEAU, 1712, p. 543, Vol I.

\section{Fazenda}

Tecido ou pano de lã de que se fazem peças de vestuário.

\section{Ferrete}

COSTA, 2004, p. 137-61.

inftrumento de ferro, he huma hafte com feu cabo, e no outro tem lavrada alguma cifra, ou figura; feito em braza fe punha na refta dos efcravos, dos ladróes; e dos gados nas ancas para fe conhecer feu dono, e haver noticia do ladrão, e faber-fe que já fizera outro roubo, de que foi perdoado.

BLUTEAU, 1712, p. 610, Vol I.

Fita

tecido longo, eftreito de láa, ou feda para atar, guarnecer \&c.

BLUTEAU, 1712, p. 619, Vol I.

\section{Flanela}

Tecido espesso e macio, onde não se vê o efeito da técnica, geralmente uma sarja batávia de 4. // Designa-se "flanela de lã" quando obtida por feltragem controlada; diz-se "flanela de algodão", quando obtida por perchagem.

COSTA, 2004, p. 137-61.

\section{Guarnecida}

part. paff. de guarnecer. § Adornado com franjas, caireis, fitas.

BLUTEAU, 1712, p. 674, Vol I. 


\section{Índigo}

(esp.Indigofera species) Planta tintureira do índigo, que apresenta várias espécies, mas das quais apenas duas interessam: a originária da Índia (esp.indigofera tinctoria) e a do Egipto e Etiópia (esp.indigofera argentea). // Corante azul, para tingir. // Cor azul.

INDIO, indino - Forma antiga de indigo

COSTA, 2004, p. 137-61.

\section{Largado}

Que se largou, que se deixou ir.Que foi abandonado ou esquecido; rejeitado, desprezado.Que não demonstra cuidado com a aparência ou modo de vestir; desleixado, relaxado: ele é meio largado, meio hippie.

HOUAISS, 2002/2003.

\section{Lenço}

lenzo (pano de) - Espécie de tecido (antigo) de linho ou algodão. // Tela de pintura ou quadro. // Tecido fino de linho usado nos lenços de assoar e em roupas de baixo ou de uso doméstico. // Pedaço quadrangular de tecido de linho, seda ou algodão. // Oral.

COSTA, 2004, p. 137-61.

\section{Linho}

(esp. linum ustatissimum) - Planta têxtil, com cujas fibras se produzem tecidos de diversas qualidades. // Tecido obtido a partir dessa fibra

COSTA, 2004, p. 137-61.

\section{Mandrião}

MANDIL - (ind.) Pano grosseiro de fabricação local, para vestuário feminino e principalmente usado para limpar ou esfregar. // Fazenda própria para capas, usada na Índia portuguesa.

Variação presente dos escritos: Mandrião

COSTA, 2004, p. 137-61.

\section{Mango}

A parte mais comprida do mangual. Designação faceta do dinheiro brasileiro:

O almoço vai custar cem mangos. [Regionalismo: Sul] Relho de cabo curto e grosso, com tala comprida e larga.

HOUAISS, 2002/2003.

\section{Manguito}

Manga pequena. Pequena manga, para enfeite ou resguardo dos punhos. Designação antiga do regalo de peles. A parte inflável do esfigmomanômetro, que circunda o braço.

HOUAISS, 2002/2003. 


\section{Manta}

Cobertor de cama de lã, em geral colorido e enxadrezado. Tira de seda ou lã que os homens enrolam ao pescoço, servindo-lhes de gravata. Lenço ou xale que as mulheres põem sobre os ombros ou na cabeça; mantilha. Grande pedaço de carne ou peixe exposto ao sol. Agricultura. Sulco para plantação de bacelo. Camada humífera; folhada. Camada que se forma ao ser sulcada a terra.

HOUAISS, 2002/2003.

\section{Medalha}

Peça de metal forjada em memória de um feito glorioso ou em honra de uma pessoa ilustre. Peça de metal concedida como prêmio de um concurso, em recompensa por atos humanitários etc. Peça de metal em que se representa o objeto de uma devoção.

HOUAISS, 2002/2003.

\section{Merino}

Diz-se de uma raça espanhola de carneiros, cuja lã, muito fina, é bastante apreciada. S.m. Tecido feito com essa lã.

HOUAISS, 2002/2003.

\section{Morim}

Pano branco e fino, de algodão.

COSTA, 2004, p. 137-61.

\section{Paninho}

Pano fino de algodão.

COSTA, 2004, p. 137-61.

\section{Pano}

(diversas designações) - crú: pano de algodão que não branqueou, depois de tecido. - da Frísia: tecidos orientais; bordados semelhantes aos executados na Frísia. - de Aragão /Castela: tecidos de lã e de seda, grosseiros, vindos daquelas regiões e vendidos nas feiras do interior. - de armar: ou panos de Arrás (tapeçarias) para ornamentar portas, galerias, paredes, etc. - de cadeira: pano de tecido rico e decorativo com que se cobria a cadeira. - de cócedra: pano que se colocava sobre os colchões. - de ervas- da - Índia: (ver Ervas da Índia) - de estante: pano de tecido rico e decorativo com que se cobriam os sitiais. - de Minde: pano de lã. - da Serra: pano grosseiro, duradouro, semelhante ao burel; surrobeco. - de treu: pano forte, para velas de navios, produzido na região do Porto e na Maia. - de varas: espécie de burel ou picotilho, muito estreito de que se faziam gabões. - família: certa qualidade de pano de algodão para roupas de casa; pano-patente; morim. - meirinhos: tecidos feitos com lã de gado meirinho; (gado ovino ou caprino que vive na montanha no Verão e na planície no Inverno); lã meirinha; o mesmo que merina I merino. - patente: tecido de algodão usado em roupas de cama. - paló: pano ordinário (da Índia portuguesa.) - piloto: tecido de lã mais macio e delgado que a saragoça; espécie de briche. - síricos: de sirgo = panos de seda. - viado: tecido riscado, decorado com listas ou riscas. 


\section{Promessa}

Compromisso de fazer, dar ou dizer alguma coisa: cumprir a promessa. Ação ou efeito de prometer. Voto feito aos santos ou a Deus para obter alguma graça. [Figurado] Esperança que se funda em aparências: a promessa de bom tempo.

HOUAISS, 2002/2003.

\section{Raminhos}

Pequeno ramo. Pequeno ramalhete. Espécie de jogo popular. [Popular] Pequeno ataque de doença, especialmente de paralisia ou estupor

HOUAISS, 2002/2003.

\section{Renda}

Trabalho delicado, gracioso, de tecido ou malha aberta, com desenhos geométricos ou outras temáticas, executado com fios diversos, podendo incluir os metálicos e destinado a enfeitar, sobretudo, têxteis ou a ser usado simplesmente. Pode ser produzido mecânica ou manualmente, utilizando agulhas, almofadas, bilros ou simplesmente os dedos.

COSTA, 2004, p. 137-61.

\section{Salpicos}

Mancha de lama ou de qualquer líquido. Pedra de sal utilizada para salgar carnes e outros alimentos. Substantivo masculino plural: Pequenos pontos de cor em certos tecidos.

HOUAISS, 2002/2003.

\section{Seda}

Substância filamentosa, produzida pela larva de um insecto chamado bicho-daseda (esp. bombyx mori). // Matéria têxtil extraída de casulos, especialmente dos produzidos por aquele insecto. Tecido feito com essa mesma substância. // Fibra animal de natureza proteica. // No plural designa trajes de seda. Existem cerca de 100 insectos, que igualmente produzem seda, mas esta é muito pouco aproveitada. Estas sedas são conhecidas pelo nome de tussah.

COSTA, 2004, p. 137-61.

\section{Sinal}

Qualquer coisa da qual vimos em conhecimento de outra com que ella tem connexão natural.

BLUTEAU, 1712, p. 402, Vol II.

\section{Tecido}

Pano preparado no tear. Trama de fios; urdidura. Modo como os fios de um estofo estão reunidos. [Biologia] Reunião de células com a mesma estrutura, exercendo determinada função. Conjunto, encadeamento, série. Cerração. Disposição, ordem.

HOUAISS, 2002/2003.

\section{Volvedor}

envolvedor. Cinta de atar crianças, larga 
APÊNDICE F - Mais alguns exemplos de escritos da roda (Lisboa e Rio de Janeiro)

Mais alguns exemplos de escritos de LISBOA

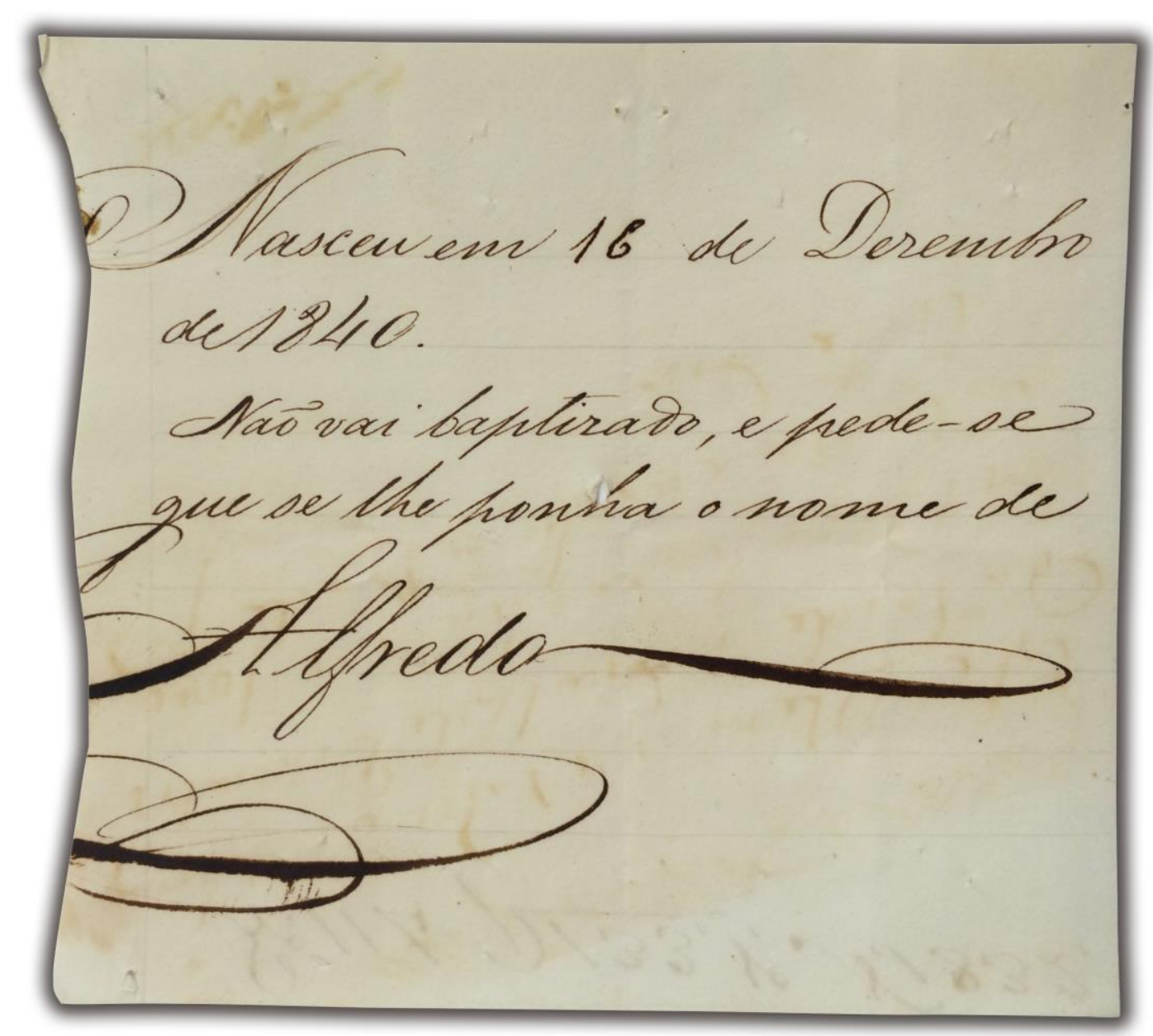




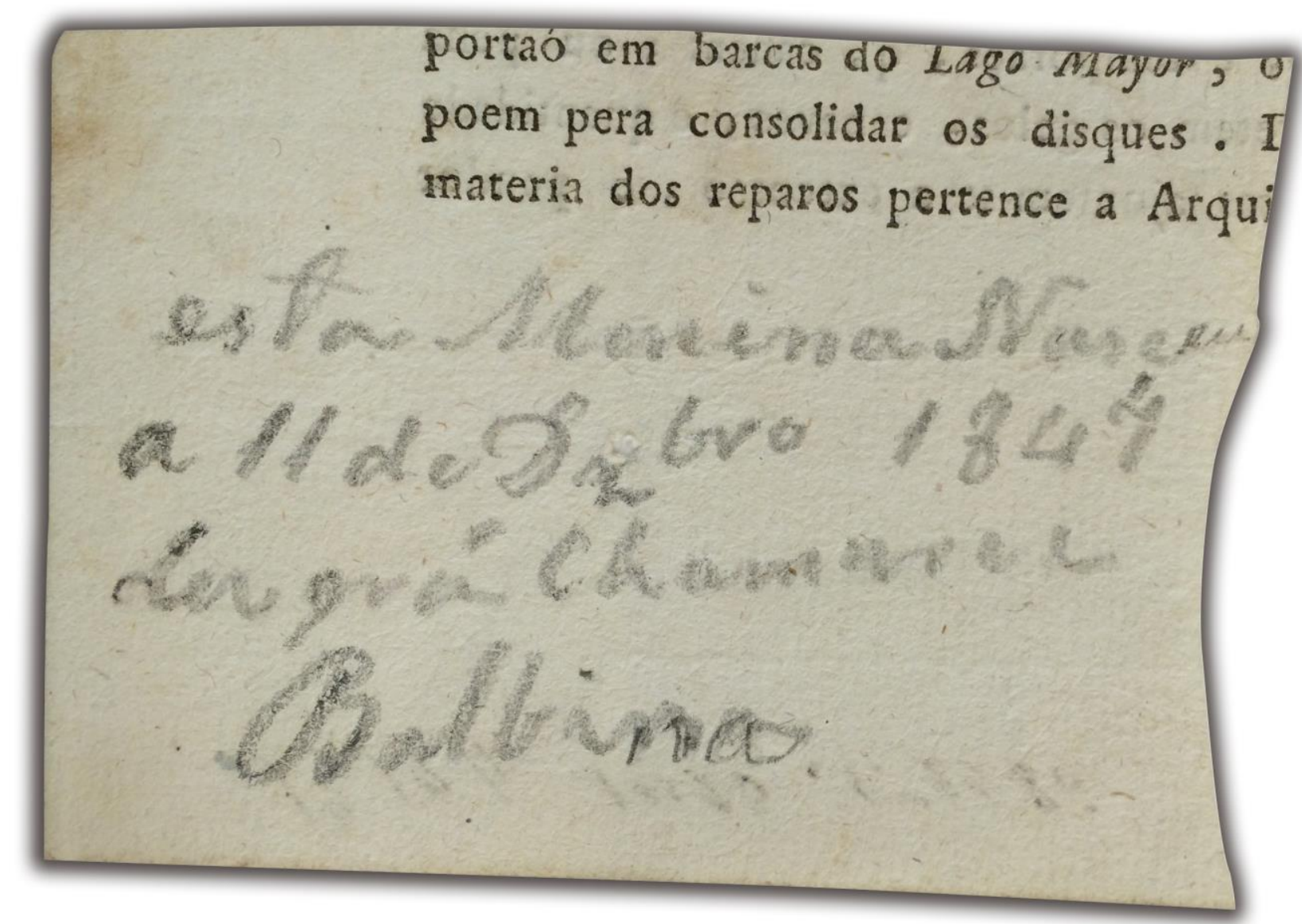


esta menina mecue a 2 de nucuentor de míl noito centos e cicoenta a cete 
349

Eita Mucuine Dinseer westin 15 le Clfoures 1813 is. G lioinda

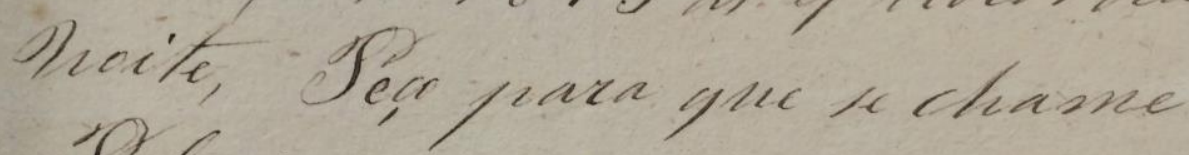
Praniza.

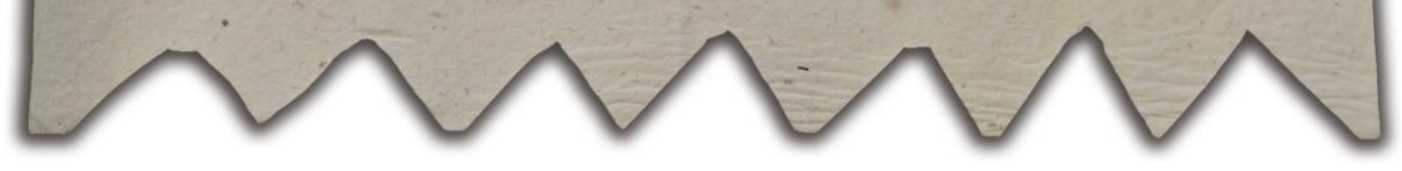




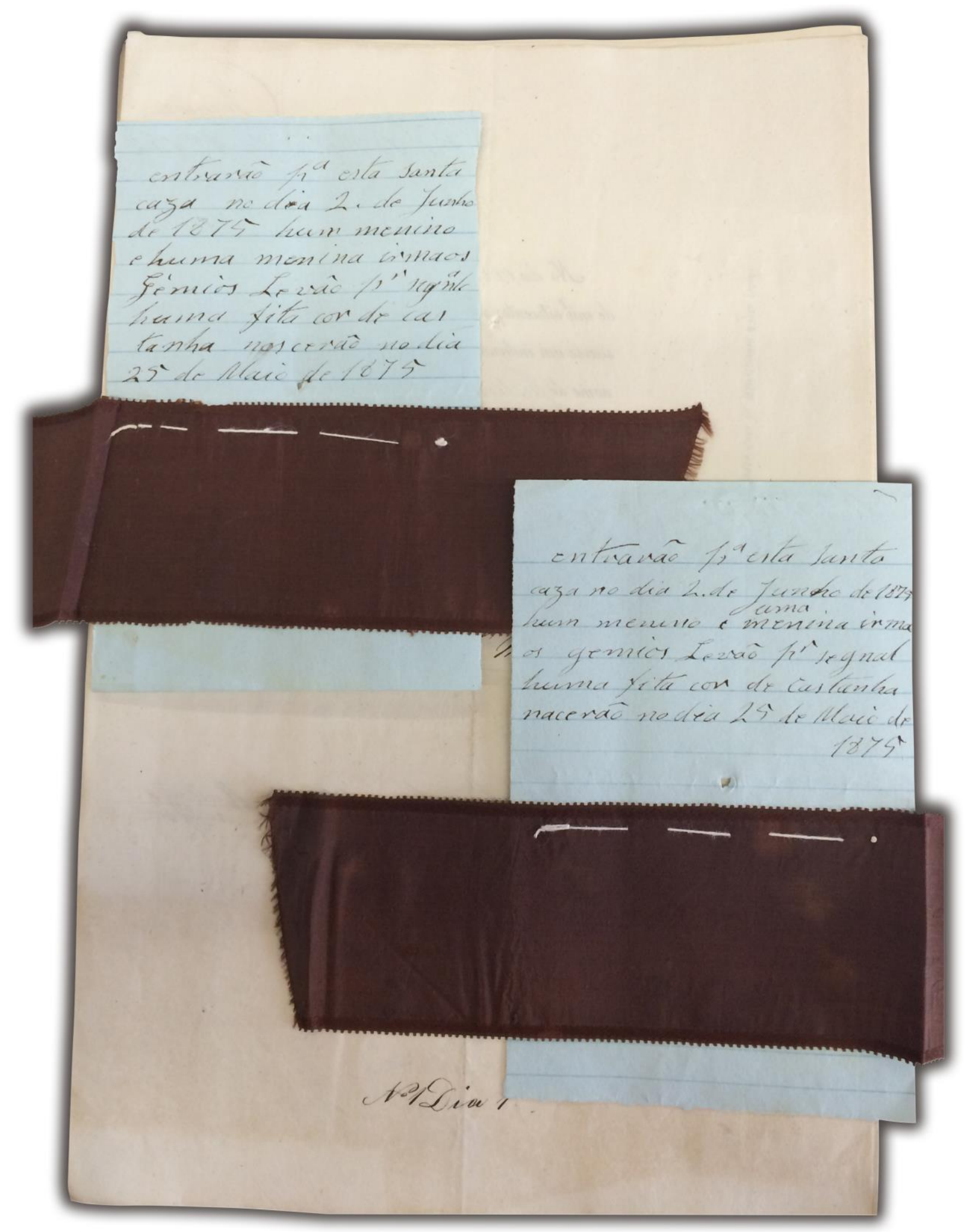


S Siprartita ese 69 porfalita desculado desuar nei

Itodo tepo siade pornomo sixamura of ntonio sirdal quileva e hum coeir's azul braxco outro incarrago karaws repixhs ay wis com linhs braxcos fita quuqiua iataclo be carteado delan Tas hogemceinve diasgin asto adoer kortas demanze Lecua kionafit ta rowe - Sratica berdo
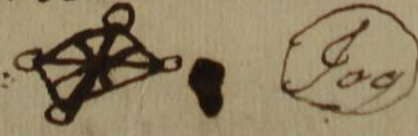
dyo quarlac dene.

vioner eyla

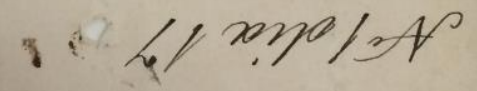

$$
\begin{aligned}
& \text { mensoras } \\
& \text { hBt at } 18 \text { fo os sovel } 75
\end{aligned}
$$


Sedese que a corte menino seja posto o nome de Giilhernag. 
354

- Siè vai Saliundose hade chamarfoe Carlas Soxe. Leire fralda de lin ho Coel ras amarelas, sinto amarelo, lestido de titu verdoe raxe, Sock de Botinet com fita ver 
Mais alguns exemplos de escritos do Rio de Janeiro

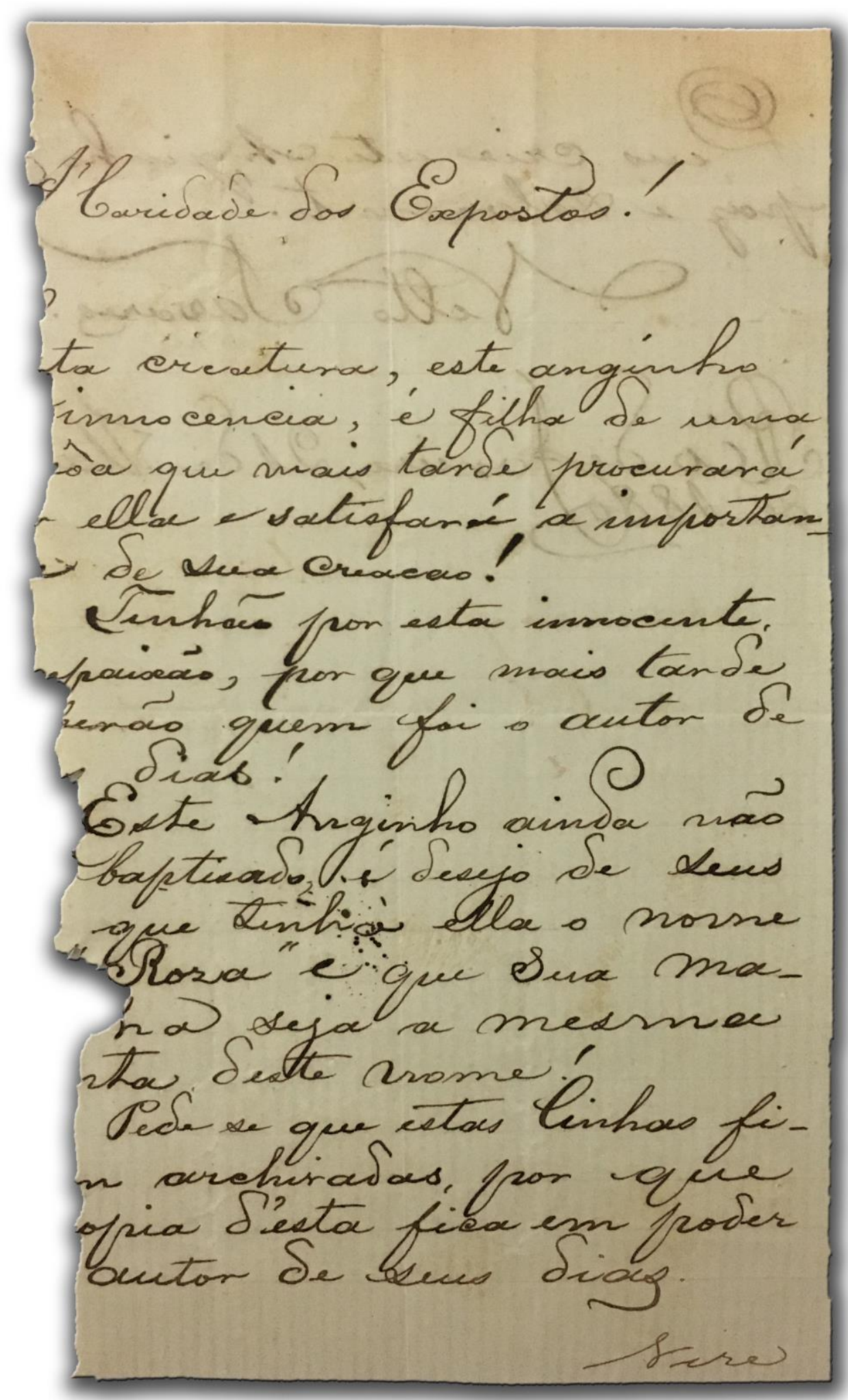


356

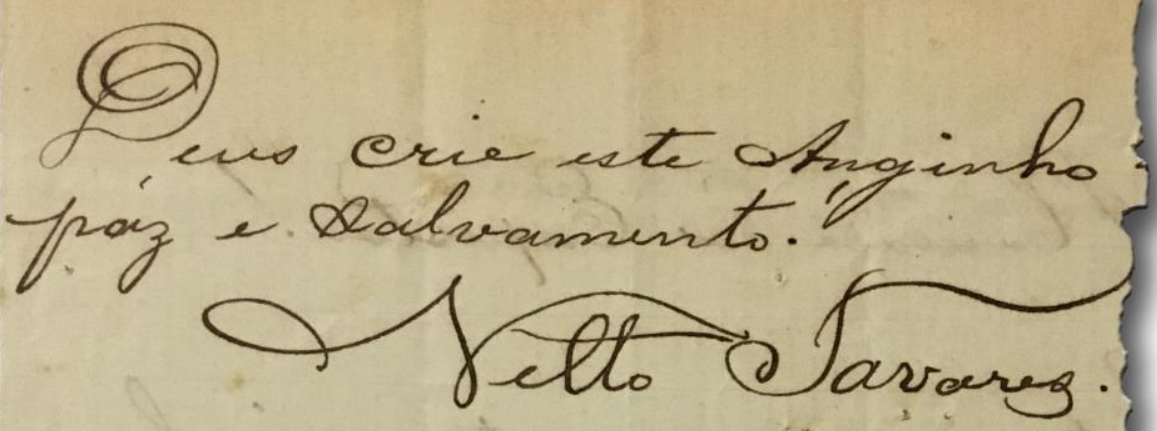

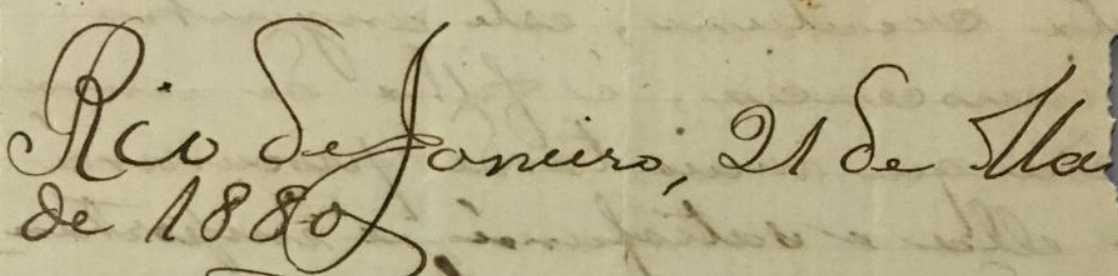


357

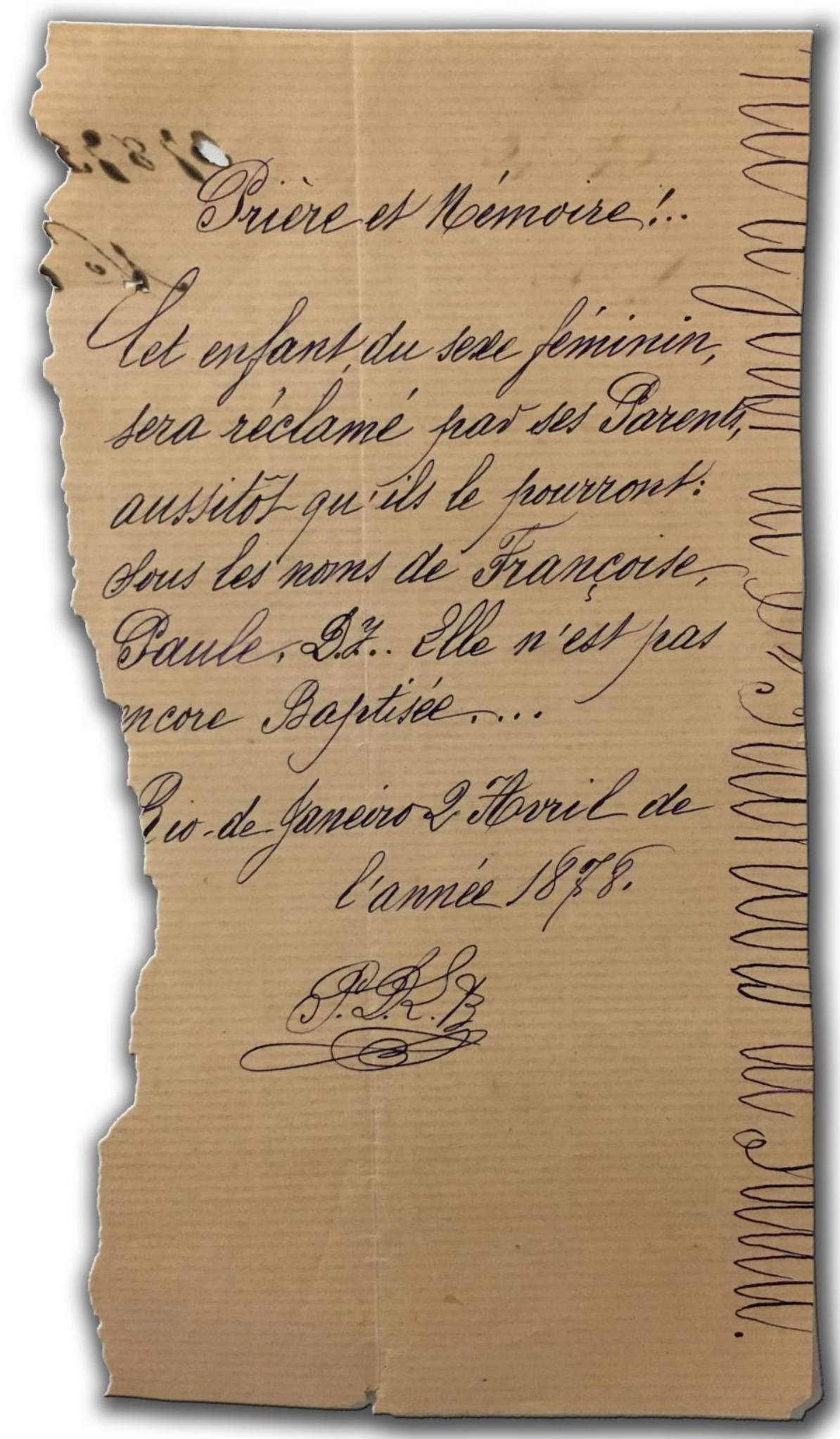


358

elaem dice 30 di e) taril di 1914hosta Griamea packe ser dada heve 
359

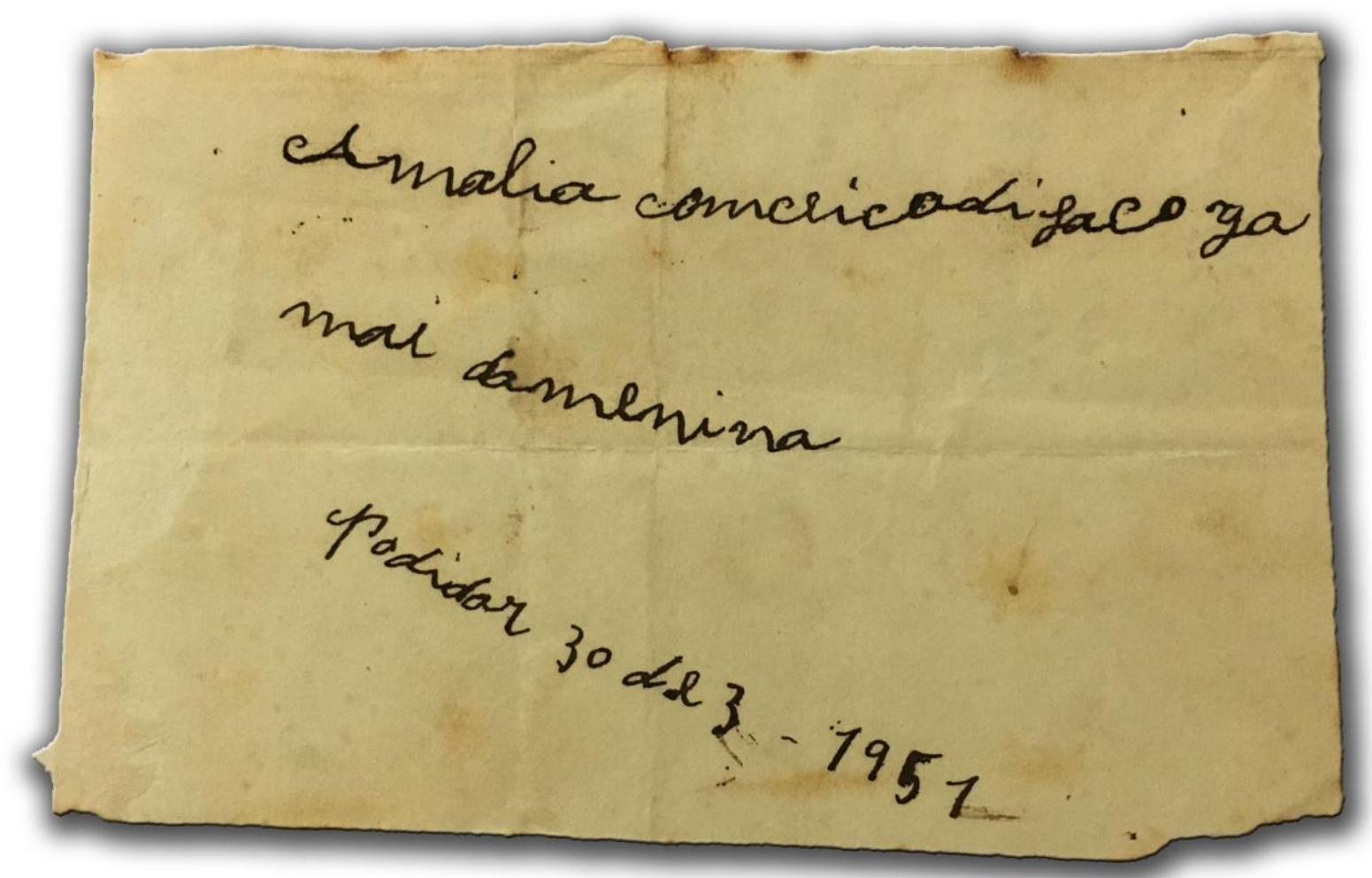


360

Esthacinauca fo deser trad a 
361

52.974

de Declarro que deixo este menano etacido ono de 24 de yunho paza ser clado

Alaria etparecida Lilva Pinkero 
362

Deixa esta creanca na casa dos Despostos e pode sex dada.

Mariayose Jilipe de Jesuz 
Pera Licia é eleiseada pela própria maie para ser dada, maseida a 17 de yomeire. 
364

E) eixopztacrianca

Parou s er of a a

alliats A gouned ou if a go

52.899 


\section{ANEXOS}

ANEXO A - A roda dos expostos na literatura ANEXO B - Iconografia 
ANEXO A - A roda dos expostos na literatura

\section{Textos literários dão testemunho sobre a roda dos expostos em Portugal e no Brasil}

Embora as obras literárias não sejam as fontes primárias de nossa pesquisa, elas fornecem elementos importantes sobre as rodas dos expostos e sobre a prática do abandono de crianças e os escritos que acompanham os bebês.

\section{Roda dos expostos retratada na Literatura Portuguesa}

Do material que encontramos, constatamos que o poeta Vasco Graça partiu do próprio texto. Encontrou nos escritos da roda matéria-prima para criar seus poemas.

Verificou similaridade na dicção, no vocabulário e nas imagens dos escritos encontrados na roda junto às crianças e os textos da tradição literária portuguesa dos séculos XVI a XVIII.

Em Portugal em 1987 Vasco Graça Moura publicou a Ronda dos meninos expostos: Auto breve de Natal. Nessa obra o autor tem como base os escritos que acompanhavam os expostos entre fins do século XVIII e meados do século XIX ${ }^{115}$.

"O colorido madrigalesco de muitos dos referidos pormenores concretos, que, na nossa literatura, faz o encanto de tantas composições em redondilha dos séculos XVI a XVIII, adquire aqui uma outra e patética funcionalidade, mas sem perda dos seus valores minuciosos texturais. Essa funcionalidade, aparentemente apenas destinada a sinalizar e a individualizar uma criança abandonada, a fim de, mais tarde, tornar possível uma sua eventual recuperaçãoo pela família, agrega possivelmente mais algumas notas subreptícias: a intenção, quase sempre proclamada, de recuperar o exposto valerá mais como álibi para o sossego da consciência, ou atitude "para não parecer mal" do que como um propósito seriamente radicado; e, ainda a participar desse sentimento, poderíamos falar também de uma "estética do abandono" no que respeita às peças de roupa e objetos levados pela criança, à sua descrição e o enunciadodos "sinais", em parte correspondentes a gestos autênticos de ternura trágica, ou a simulacros dela, mas talvez também ao comprazimento da mãe na organização de um "enxoval" para o o seu filho. Até poderíamos encontrar indícios de uma "hierarquia" socieconómica dos abandonantes." p.7-8.

Prólogo

Estamos na santa casa,

\footnotetext{
115 Por meio do catálogo da exposição "Sinais dos Expostos". Conforme informa o autor na introdução
} de sua obra na p.7. 


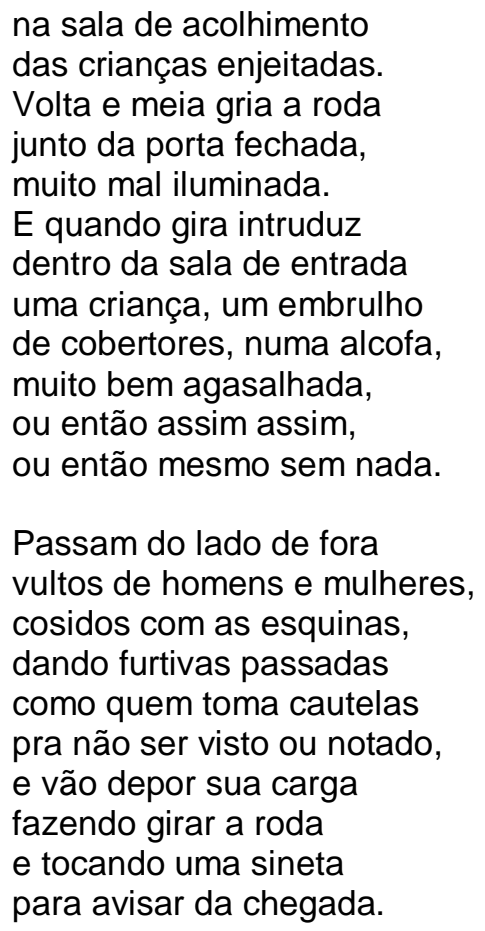

\section{Transfigura poeticamente este material}

Sequência IX que tem como personagens $1^{\circ}$ e o $2^{\circ}$ secretários e a $1^{\mathrm{a}}$ criada.

3 falas em redondilha maior

Contraste entre as três partes

A primeira é neutra, a segunda apresenta muita vivacidade e quando se refere aos olhos da criança, depois quando descreve o enxoval com detalhes como cores, brilho, texturas, menciona o sino-saimão e o vintém que remetem à proteção e ao valor material, uma vez que são de prata.

$1^{0}$ secretário: Com seus oito meses feitos pro hospital vai Jerónima.

1 ${ }^{\mathrm{a}}$ criada: Tem os olhos muito pretos, vestido de baetilha de salpicos coloridos, brancos, azuis, encarnados, e um cueiro azul também de baetilha de pelo e outro velho e amarelo de fazenda de cordão, e ao pescoço a meia-lua e ainda um sino-saimão e um vintém, tudo de prata. 
$2^{\circ}$ secretario: Vai muito magra e doente.

\section{Roda dos expostos retratada na Literatura Brasileira}

No Brasil, a situação dos expostos e a instituição da roda também foi tratada literariamente na ficção.

Encontramos também a presença da roda dos Expostos e da prática do abandono de crianças, mas, na ficção de fins da segunda metade do século XIX.

Foram os romantistas que trataram a questão da roda não a partir dos escritos, mas sob a perspectiva

O romancista Joaquim Manuel de Macedo trata da "roda dos enjeitados" em seu romance Luneta Mágica, de 1869. O narrador descreve o mecanismo da roda para o leitor:

Em outra ocasião, passando pela Rua dos Barbonos, parei diante de uma casa consagrada ao mais piedoso e santo mister, e vi armado em sua parede aquele aparelho movediço que se chama—roda dos enjeitados. Ora pois! disse a mim mesmo; aqui é impossível que eu descubra o mal; porque neste caso o mal está somente na mãe, ou na família cruel, que enjeita o recémnascido; mas no seio que se abre para recebê-lo, salvá-lo, adotá-lo não pode estar senão o bem, a caridade, a santidade.

MACEDO (1869, p.54).

Na sequência, tece um arrazoado comentário, com uma série de argumentos sobre o valor moral da existência da roda e dos procedimentos de quem abandona e da finalidade da roda das consequências e do valor:

E fitei a minha luneta na roda por mais de três minutos: quem o diria?... a roda da piedade bem depressa pareceu-me antes protetora do vicio e da desmoralização, do que providência salvadora de inocentes criancinhas condenadas; essa roda afigurou-se-me leito ruim de falsa caridade, porta do abandono, da perdição, talvez algumas vezes do cativeiro dos míseros enjeitados; li no berço dessa roda cem lúgubres histórias, e recuando espantado, preferi a miopia à visão do mal, e cheguei a pensar que para muitos dos enjeitados e para a sociedade fora melhor a sepultura, do que a roda. E retirei-me, meditando, refletindo sobre o que acabava de ver. Fique de parte a questão moral, social da conveniência de tais estabelecimentos de caridade, Que faz a roda ao enjeitado? Se pode, livra-o da morte; mas depois condena-lhe a vida: era talvez preferível deixá-lo morrer. Ser ou não ser: se a instituição é de caridade, seja-o plenamente, não se desnature, recorrendo a meios que em regra geral são fatais aos enjeitados; se não pode sê-lo plenamente, não cumpre o seu fim. Que faz a roda? Recebe o enjeitado, e depois enjeita-o por sua vez. A verdadeira caridade não enjeita. A roda que faz? Dá os enjeitados a criar, a quem os vem pedir e os leva a dez, a vinte, a cinqüenta e mais léguas de distancia, e fica muito contente de si, porque paga a criação do enjeitado por dois terços menos, do que de ordinário custa 0 aluguel de uma ama. E por esse preço insuficientíssimo criar enjeitados é negócio que se explora! Que fortuna espera ao enjeitado que a roda assim 
por sua vez enjeita? Faz tremer pensá-lo. O mísero inocente é feliz, se acha seios de mulher em que se aleite, e fica apenas analfabeto e sem educação; a sociedade é que não pode esperar ser felicitada por semelhante enjeitado de roda. E o que não é feliz desse modo tão infeliz?...

E o enjeitado que fica reduzido a escravo da família que o foi pedir?... e o enjeitado que morre à mingua longe da roda que o enjeitou, e que paga sua criação muitos meses além da afortunada morte do mísero condenado? E o enjeitado de cor preta, ou de cor menos branca, que tão facilmente substitui o escravo que morre, e que toma dele o nome para ser vendido pela perversidade de algum infame dentre os negociantes de criação de enjeitados? Esta ultima idéia, a suspeita da possibilidade... talvez da realidade de tão grande crime penetraram no meu espírito, como punhais ervados que me rasgassem o coração. Tudo pois que eu via no mundo era maléfico, pavoroso, medonho!

MACEDO (1869, p.55).

Em dos mais conhecidos contos de Machado de Assis, Pai contra Mãe, o personagem Cândido Neves, pressionado pela falta de recursos, vê-se na iminência de deixar o filho na roda dos Expostos.

"O credor entrou e recusou sentar-se, deitou os olhos á mobília para ver se daria algo à penhora; achou que pouco. Vinha receber os aluguéis vencidos, não podia esperar mais; se dentro de cinco dias não fosse pago, pô-lo-ia na rua. Não havia trabalhado para regalo dos outros. Ao vê-lo, ninguém diria que era proprietário; mas a palavra supria o que faltava ao gesto, o pobre Cândido Neves preferiu calar a retorquir. Fez uma inclinação de promessa e súplica ao mesmo tempo. O dono da casa não cedeu mais.

-Cinco dias ou rua! Repetiu, metendo a mão no ferrolho da porta e saindo. Candinho saiu por outro lado. Nesses lances não chegava nunca ao desespero, contava com algum empréstimo, não sabia como nem onde, mas contava. Demais, recorreu aos anúncios. Achou vários, alguns já velhos, mas em vão os buscava desde muito. Gastou algumas horas sem proveito, e tornou para casa. Ao fim de quatro dias, não achou recursos; lançou mão de empenhos, foi a pessoas amigas do proprietário, não alcançando mais que a ordem de mudança.

A situação era aguda. Não achavam casa, nem contavam com pessoa que Ihes emprestasse alguma; era ir para a rua. Não contavam com a tia. ... Assim sucedeu. Postos fora de casa, passaram ao aposento de favor, e dous dias depois nasceu a criança. A alegria do pai foi enorme, e a tristeza também. Tia Mônica insistiu em dar a criança à roda. "Se você não a quer levar, deixe isso comigo; eu vou à Rua dos Barbonos." Cândido Neves pediu que não, que esperasse, que ele mesmo a levaria. Notai que era um menino, e que ambos os pais desejavam justamente este sexo. Mal Ihe deram algum leite; mas como chovesse à noite, assentou o pai leva-lo à roda na noite seguinte."

MACHADO DE ASSIS (1906, p. 7)

\section{O historiador e bibliotecário José Vieira Fazenda ${ }^{116}$ publicou crônicas} dedicadas à roda dos Expostos em sua obra Antiqualhas e Memórias do Rio de Janeiro.

${ }^{116}$ Foi bibliotecário do Instituto Histórico e Geográfico Brasileiro por aproximadamente 20 anos e foi lá que as Memórias e Antiqualhas do RJ, com sua morte em 1917, a sala de leitura do IHGB passou a ter seu nome. 
A abertura do texto roda I narra a aquisição do imóvel para funcionamento da casa dos expostos:

Abertura do texto roda I, Antiqualhas e Memórias do Rio de Janeiro

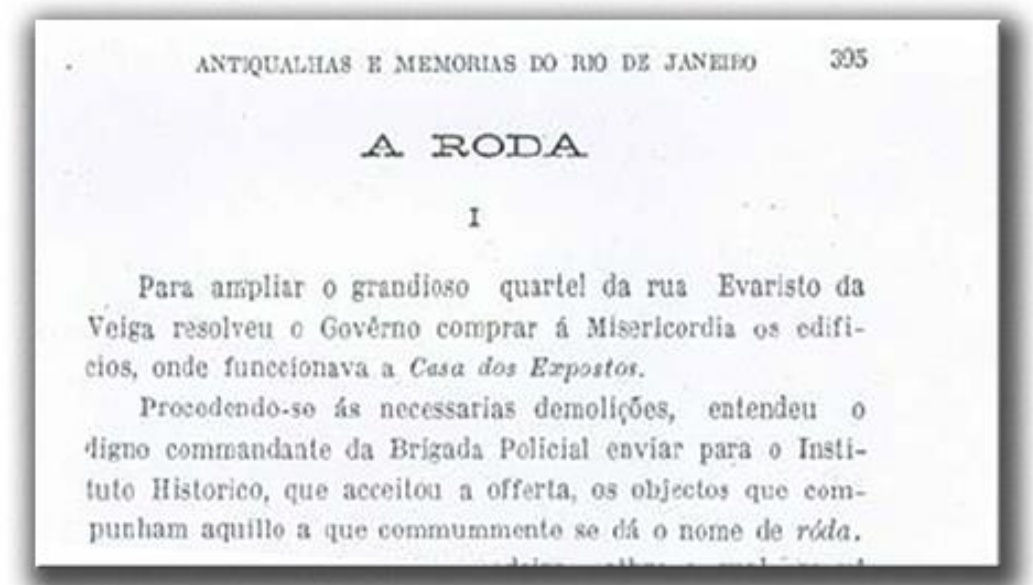

Fonte: RIHGB: Rio de Janeiro, IHGB, v. 149, p. 395, 1924

O autor tece diversas considerações sobre a prática do abandono de crianças, compilando dados históricos, cotejando documentos oficiais e acrescentando considerações de cunho pessoal.

Afirma que a roda do RJ salvou muitos negros da escravidão.

"Salvou da escravidão centenas de inocentes que, engeitados por seus senhores, eram depois reclamados. $E$ isto no tempo em que era loucura falar em emancipação dos captivos." (FAZENDA, 1924, p. 409) 
Abertura do texto roda IV, Antiqualhas e Memórias do Rio de Janeiro, In: RIHGB: Rio de Janeiro, IHGB, v. 149, p. 409, 1924

ANTIQUALHAS E MEMORIAS DO RIO DE JANEIRO

\section{A. RODA}

IV

No intuito de dar bom regime o regularidade ao serviço das Casas dos Engeitados, promulgou o rei d. José I o alvará de 31 de Janeiro de 1775 .

Com ser extenso esse documento, vai elle transcripto na integra por se prender ao historico da nossa Roda.

Demais essa lei serviu de base ao regulamento de 1 de Abril de 1840, apresentado e epprovado pela Mesa, de que era provedo: o benemerito José Clemente Pereira, e mandado executar por decreto de 4 de Julho do mesmo anno.

Suas determinagóes sấo ainda hoje mais ou menos seguidas pelas mesas, que se tên succedido.

Foi ainda escutado nesse alvará, que a Sanota Casa do Rio de Janeiro escreveu em seus annaes uma das mais bellas paginas de sua historia.

Salvou da esorayidão centenas de innocentes que, engeitados por seus senhores, eram depois reclamados. $\mathrm{E}$ isto no tempo em que era loucura fallar em emancipação dos captivos. 
Abertura do texto roda V, Antiqualhas e Memórias do Rio de Janeiro, In: RIHGB: Rio de Janeiro, IHGB, v. 149, p. 413, 1924

\section{A IRODA}

$\nabla$

Cruz preta, pintada no portal de uma casa, indicava, nos tempos antigos, a residencia de parteira.

Disseminadas aqui e alli, polos becos e viellas do Rio de Janeiro, não tinham mãos a medir. Sem leis coercitivas exerciam com plena liberdade os difficeis encargos da profissão.

Depositarias de graves segredos, conhecedoras de muitas vergonhas e escandalos, gosavam de grande respeito e dispunham de boas amizades.

Dividiam-se em duas classes: a primefra, a mais numerosa, comprehendia as simples curiosas ,aparadeiras, 'vulgarmente conhecidas pelo nome de comadres.

Da segunda faziam parte as que tinham carta de approvação. O exame era prestado perante os commissarios do proto-medicato, e em tempos posteriores na presenca do cirurgião-mór on de seus delegados.

No numero destas ultimas liavia tambem escravas. $E^{\prime}$ hem de ver que os proventos da profissão iam encher as algiberras do feliz senhor, que tinha a felicidade de contar entre seus eaptivos uma mulata ou negra, ladina, entendida em parto .

Nos archivos da nossa Municipalidade devem existir ainda os registos dessas curiosas cartas de approvação. Ainda depois da Independencia custavam ellas: de feitio tres mil e duzentos, de assignatura mil o duzentos, e de impressão seis mil e quatrocentos réis.

As curiosas, por serem maís baratas, eram em geral encarregadas de levar a Roda os recem-nascidos escravos, cujos senhores não queriam ter os incommodos da criaçâo.

Prestados os soccorros á parturiente, voltava á noite a aparadeira e, mediante modica retribuição, recebia o fardo arraneado d́s caricias da pobre mãe $\mathrm{e} o$ ia depositar na portinhola da Casa dos Expostos. 
SOARES, Jô. O xangô de Baker Street. São Paulo: Companhia das Letras, 1995. p. 209-213.

Em 1693, aflito com a impiedade e o abandono em que eram deixados os órfãos recém-nascidos, perecendo nas vielas de frio e inanição, o governador Antonio Paes de Sande enviou carta a el-rei Pedro II de Portugal, pedindo providências, pois a Santa Casa de Misericórdia não podia recolhê-los por não ter rendimentos suficientes. $O$ Senado da Câmara também não mostrava interesse algum na criação daqueles pobres inocentes. Como Portugal havia acumulado imensa riqueza graças às minas de ouro apenas descobertas no Brasil, el-rei, sentindo-se benevolente, ordenou em resposta que os desprotegidos fossem alimentados pelos bens do Conselho, e que para isso se impusessem as contribuições necessárias para a piedosa tarefa.

A Câmara começou a empregar as sobras de alguns impostos na criação dos pequenos infelizes que eram lançados ao desamparo nas ruas e, em alguns casos, até devorados pelos cães. Não havia, contudo, recursos certos para a obra.

Tendo o abandono e a miséria dos pequeninos sem pais comovido o coração generoso de um certo Romão de Mattos Duarte, este resolveu doar, em janeiro de 1738, trinta e dois mil cruzados à Santa Casa da Misericórdia, para a criação dos enjeitados. Estava fundada a roda dos Expostos.

A roda era assim chamada porque, à entrada lateral do edifício, havia uma porta grossa de madeira sobre a qual se via uma fresta tapada por um cilindro giratório, também de madeira, com duas prateleiras onde depositavam os bebês indesejados. Dando um pequeno impulso, girava-se o cilindro com facilidade e o enjeitado desaparecia pela fresta, indo para dentro da casa. Uma campainha posta em comunicação com o aparelho giratório servia de aviso às irmãs de caridade que recolhiam, sobretudo à noite, as criancinhas abandonadas.

A roda dos Expostos começou no largo da Misericórdia, esteve na rua de Santa Thereza, porém, desde 1860, funcionava num prédio de dois pavimentos, no número 66 da rua Evaristo da Veiga, onde anteriormente se instalava a Escola de Medicina.

A nova roda dos Expostos fora inaugurada em junho daquele ano com a presença da família imperial. O vestibulo era revestido de mármore, tendo de um lado a secretaria de pagamento para as amas externas, enfermeiras que trabalhavam para a Santa Casa, e do outro, a Sala da roda. Junto à roda, permanecia constantemente uma irmã de caridade para recolher os abandonados. Ladeando a escada central, 
viam-se as estátuas de São Vicente de Paula e a da Caridade. No primeiro pavimento, ficavam o refeitório, a sala de recreio, a sala de engomar, a cozinha, os tanques de lavagem de roupa e o jardim. No segundo, a sala da administração, o gabinete da irmã superiora, a capela, a botica, a sala de leitura, a de costuras, os aposentos das irmãs de caridade, uma sala com quarenta berços e o dormitório das expostas com quarenta e dois leitos. Óleos de Pedro I e a imperatriz Leopoldina, de d. Pedro II e da imperatriz $d$. Teresa Cristina enfeitavam as paredes ${ }^{117}$. As recolhidas que ali residiam aprendiam a ler, escrever, a contar, gramática, história sagrada, trabalhos de agulha e de engomar. As que mais tarde se casavam recebiam um dote oferecido pela irmandade. Todos os anos, a princesa Isabel enviava à roda dos Expostos baús contendo vestimentas feitas por suas próprias mãos, ato que revelava a imensa bondade de seu coração.

Mostrando que a roda dos Expostos não se esquecia de seus benfeitores, havia também um quadro de seu fundador, o caridoso Romão de Mattos Duarte. No entanto, o que mais comovia os visitantes era o retrato, na sala dos berços, de uma criança hidrocefálica que fora lançada à roda por uma desconhecida, em julho de 1882, e falecera dois meses depois. Antes de morrer, ele fora batizado com o nome de Mateus. Mateus era um símbolo para todos os que trabalhavam na roda.

O que ninguém sabia era que, há mais de três anos, a mãe de Mateus trabalhava na roda dos Expostos. Chamava-se Carolina de Lourdes e era filha de Josué Calixto, um conceituado agente funerário estabelecido à rua Itapiru, bem ao lado do cemitério de São Francisco de Paula, no largo de Catumbi. Carolina acreditara nas falsas promessas de Ariel Lemos, um jovem que viera de Curitiba aprender os segredos do embalsamamento com Calixto. Ariel seduzira a linda menina de dezessete anos, depois fugira para o interior da província do Paraná e nunca mais dele se soubera. Josué Calixto, viúvo, homem severo, inflexível, leitor assíduo do Velho Testamento, expulsou a filha de casa. Não fosse a interferência de uma tia solteira de Niterói, que a recolhera em sua casa, certamente Carolina haveria de seguir a dificílima vida fácil das prostitutas.

Assim que o menino nasceu, Carolina, horrorizada, atribuiu a deformidade da criança à iniqüidade. Uma semana depois, rompendo o resguardo deixara na roda 0 infeliz fruto do seu pecado. Reaproximara-se do pai, que a perdoara depois de obrigá-

\footnotetext{
${ }^{117}$ Vide Anexo - Iconografia, com a representação dessa imagem.
} 
la a longa penitência. Todavia, o remorso começou a tirar o sono da bela Carolina. Passava noites em claro, pensando no pobre menino enfermo que depositara na madeira fria da roda. Na escuridão do seu quarto, imaginava enxergar os grandes olhos baços da criança olhando-a sem pestanejar. Um dia, não suportando mais a culpa, dirigiu-se à roda dos Expostos. Qual não foi seu choque ao ver que seu filho havia morrido, e se transformara na criança símbolo da entidade. Sem se dar a conhecer, resolveu que tinha que fazer alguma coisa em prol daqueles enjeitados que, como seu filho, eram atirados à mercê da caridade alheia. Com o consentimento do pai, passou a servir à roda como ama externa, sem receber nenhum estipêndio pelo trabalho. "O maior pagamento é o conforto que proporciono aos miúdos", costumava dizer, referindo-se aos pequenos infortunados. Todos estranhavam ao ver aquela jovem de extraordinária beleza, quase menina, dedicando-se com tanta paciência àquela árdua tarefa. Era adorada na roda. Carolina não tinha horas, oferecia-se para a vigília junto à roda quando alguma irmã adoecia e, no dia seguinte, continuava até tarde cuidando dos necessitados.

Naquela noite chuvosa, Carolina de Lourdes saiu da roda dos Expostos depois das onze horas. Há dois dias não voltava para casa, e seu pai, apreensivo, exigira que ela descansasse um pouco, antes que sucumbisse à pura exaustão. Ficou de buscála com seu coche ao final da tarde, contudo a chuva intensa tinha impedido a passagem da caleche. As irmãs insistiram para que Carolina dormisse lá mesmo, porém a moça descartou a possibilidade. Disse que seu pai andava quase tão abandonado quanto "seus miúdos" e desceu, em meio à tempestade, pela rua Evaristo da Veiga. 



\section{ANEXO B}

D. Pedro II e D. Leopoldina visitam a roda dos expostos do Rio de Janeiro

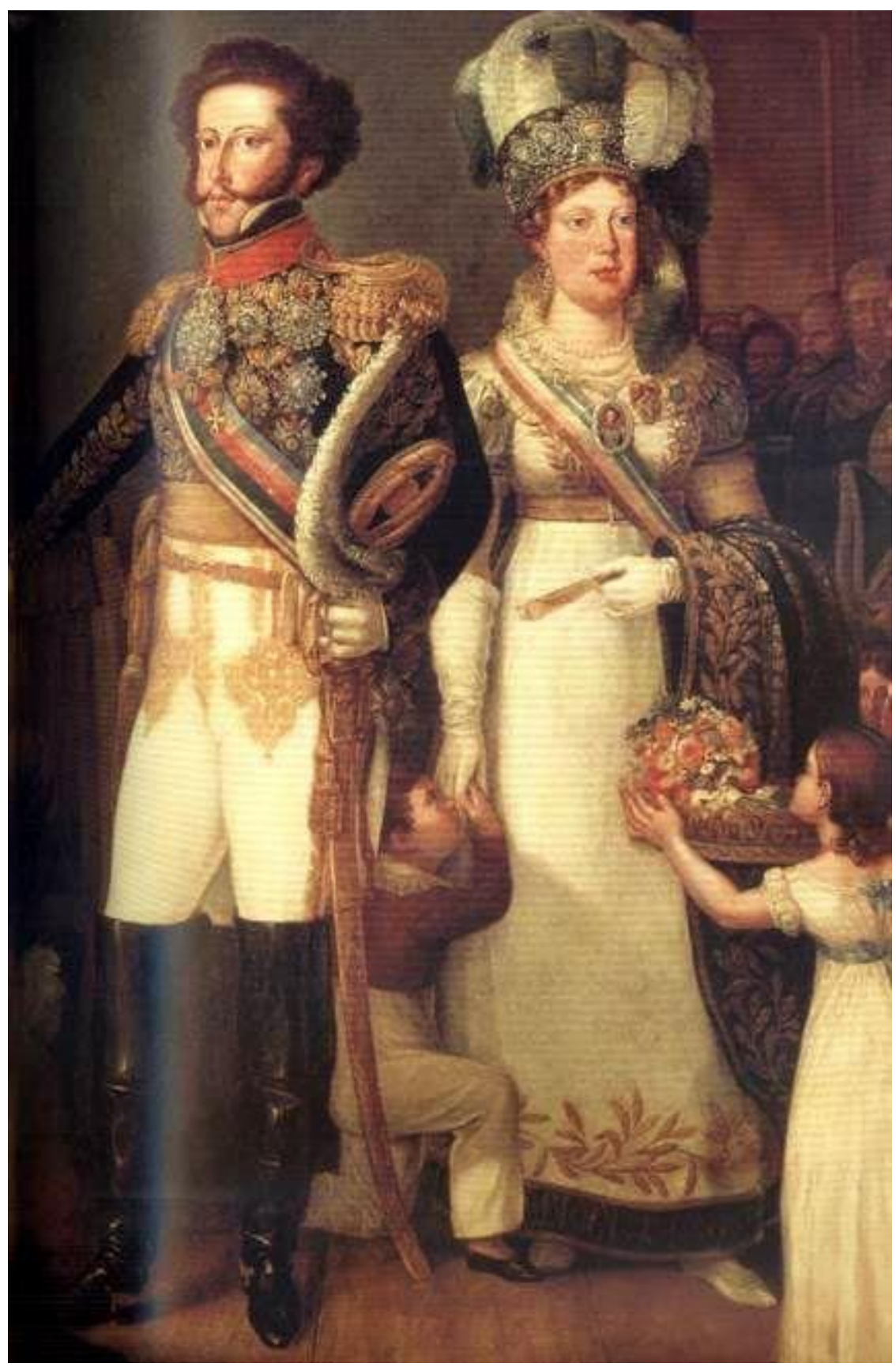

Reprodução da pintura da visita de D. Pedro II e D. Leopoldina a roda dos expostos do Rio de Janeiro

Fundação Romão Duarte, Rio de Janeiro.

Fonte: Rezzutti, P. D. Pedro - a história não contada. São Paulo: LeYa, 2015, p. 13. 


\section{NORMATIZAÇÃO ADOTADA}

Esta tese adotou as normas de publicação Diretrizes para apresentação de dissertações e teses da USP: parte I (ABNT) / Sistema Integrado de Bibliotecas da USP; Vânia Martins Bueno de Oliveira Funaro, coordenadora; Vânia Martins Bueno de Oliveira Funaro. [et al.]. - 3.ed. rev. ampl. mod. São Paulo : SIBiUSP, 2016. 100p. (Cadernos de estudos; 9). 